НАУКОВО-ДОСЛІДНИЙ ІНСТИТУТ

ПРИВАТНОГО ПРАВА І ПІДРРСМНИЦТВА

ІМЕНІ АКАДЕМІКА Ф. Г. БУРЧАКА

НАЦІОНАЛЬНОЇ АКАДЕМІЇ ПРАВОВИХ НАУК УКРАЇНИ

Кваліфікаційна наукова праця на правах рукопису

ПОПОВИЧ ТЕТЯНА ГРИГОРІВНА

Прим. №

УДК 346.544.42:340.5:339.9.012.23

\title{
СТАНДАРТИЗАЦІЯ ЯК ЗАСІБ РЕГУЛЮВАННЯ ГОСПОДАРСЬКОЇ ДІЯЛЬНОСТІ
}

\author{
12.00 .04 - господарське право; \\ господарсько-процесуальне право \\ Галузь знань «081 - Право» \\ Подається на здобуття наукового ступеня кандидата юридичних наук \\ (доктора філософії) \\ Дисертація містить результати власних досліджень. \\ Використання ідей, результатів і текстів інших авторів мають \\ посилання на відповідне джерело \\ /Т. Г. Попович
}

Науковий керівник

Деревянко Богдан Володимирович, професор, доктор юридичних наук

Київ 2018 


\section{АНОТАЦІЯ \\ Попович $T$. $Г$. Стандартизація як засіб регулювання господарської}

діяльності. — Кваліфікаційна наукова праця на правах рукопису.

Дисертація на здобуття наукового ступеня кандидата юридичних наук (доктора філософіiі) за спеціальністю 12.00.04 «Господарське право; господарськопроцесуальне право» (081 - Право). - Науково-дослідний інститут приватного права і підприємництва імені академіка Ф. Г. Бурчака Національної академії правових наук України. Київ, 2018.

Дисертація є одним із перших в Україні досліджень стандартизації з позицій наукознавчого аналізу становлення господарського права в Україні і світі та можливостей застосування стандартизації як універсального засобу регулювання господарської діяльності. У роботі пропонується позиція про взаємозв'язок економічних відносин (створення ринків для обороту товарів і послуг) з появою усталених правил, що поступово трансформуються у вимоги до якісних, кількісних та технологічних ознак товарів та послуг. Ці вимоги мали спочатку i нині мають добровільний характер. Лише введення їх у дію актами законодавства спричиняє обов'язковість. Розвиток суб'єктів господарської діяльності та поширення глобалізаційних процесів у суспільстві зумовили поступовий перехід від технічного розуміння стандартизації до безпекового, від зосередження на діяльності учасників господарських відносин до задоволення інтересів кінцевих споживачів, а також відхід від зацикленості вимог стандартизації в межах однієї країни та перехід до вимог, що використовуються світовими економічними організаціями та/чи регіональними об’єднаннями (колективними суб’єктами міжнародного права).

Міждисциплінарний підхід з використанням сучасних методів наукового пізнання суспільних явищ та процесів, досягнень господарського права надав можливість позбавитись односторонності при аналізі об’єкта та врахувати всі істотні аспекти впливу стандартизації на господарську діяльність та іiі здатність регулювати суміжні відносини, що породжуються господарською діяльністю. У 
результаті дослідження автором сформульовано та обгрунтовано низку положень, висновків та пропозицій, яким властиві елементи наукової новизни.

Автор дослідження створила i довела ряд положень, висновків та пропозицій, що мають елементи наукової новизни. Запропоновано визначати стандартизацію як вид діяльності, що характеризується такими ознаками: а) здійснюється через взаємний вплив суб’єктів господарської діяльності, держави (iї органів) та інших зацікавлених осіб один на одного; б) забезпечує оптимальне поєднання ринкового саморегулювання та державного регулювання; в) метою є захист економічних і безпекових інтересів держави, суспільства та окремих споживачів; г) установлює (як прояв статичного стану) та застосовує (як прояв динамічного стану) вимоги для загального та неодноразового використання.

Обгрунтовується положення про те, що стандартизація як засіб (інструмент) регулювання господарських відносин має універсальне застосування, оскільки іï вимоги: а) здійснюють вплив на усі господарські відносини; б) створюють умови для їх виникнення та реалізації; в) надають можливість переводити соціальні (позаправові) норми у правове поле; г) у разі недотримання чи невиконання підставою для виникнення охоронних правовідносин.

Діяльність зі стандартизації має дві складові: технічну та безпекову. Технічна складова забезпечує діяльність суб'єкта господарської діяльності 3 виготовлення товарів та/чи надання послуг відповідної якості. Безпекова створює умови для того, щоб вказаний суб'єкт враховував інтереси суспільства та/чи окремої людини, а також забезпечував безпеку довкіллю, державі та/чи кінцевим споживачам.

Представлено авторську класифікацію суб'єктів стандартизації в господарському праві 3 позиції їх участі у процесах чи діяльності зі стандартизації, незалежно від форми власності та належності їх до різних категорій, на тих, що: а) створюють стандарти чи інші вимоги стандартизації; б) здійснюють господарську діяльність та використовують стандарти чи інші вимоги стандартизації; в) підтверджують відповідність товарів (послуг) 
стандартам чи іншим вимогам стандартизації; г) контролюють дотримання стандартів чи інших вимог стандартизації.

Встановлено співвідношення в національному законодавстві понять «стандартизація» та «технічне регулювання» як різнорівневих понять (родового та видового відповідно). У дослідженні визначається поняття «технічна норма», яке, на відміну від поширеної думки про іiі технічну (позаправову) природу, прирівнюється до обов'язкового правила поведінки у суспільстві, що об'єктивно визначається рівнем техніки та використовується у промисловості для обслуговування та використання об'єктів природного чи штучного походження 3 метою задоволення потреб людини та/чи інтересів суспільства.

При дослідженні охоронних відносин виявлено такі склади господарських правопорушень у сфері стандартизації: а) недотримання вимог (при імперативності дотримання вимог нормативно-технічних документів із стандартизації будь-яке порушення чи не виконання однієї 3 таких вимог спричиняє недотримання); б) невиконання вимог (диспозитивність, свобода вибору та наявність варіантів поведінки при виконанні вимог нормативнотехнічних документів із стандартизації у разі порушення обраного варіанту поведінки спричиняє виникнення відповідальності).

Встановлено, що процедура підтвердження відповідності залежить від волі суб'єктів стандартизації, а тому їі слід визначати як необов'язковий (додатковий) вид діяльності зі стандартизації, що може завершити процес правореалізації або створити передумови для настання відповідальності для суб'єктів господарської діяльності.

Узагальнення світових тенденцій та систематизація підходів щодо стандартизації як засобу регулювання господарської діяльності в різних країнах надали можливість розробити практичні рекомендації щодо: необхідності зменшення обсягу державного регулювання господарської діяльності 3 максимальним застосуванням саморегулювання при формуванні та застосуванні вимог стандартизації; створення умов та законодавчих підстав для застосування 
зовнішнього контролю за здійсненням господарської діяльності із застосуванням безпекових вимог стандартизації; підвищення якості товарів (послуг) шляхом впровадження як вимог стандартизації науково-технічних досягнень, що використовувалися (апробовувалися) понад чотири роки.

Автор пропонує зосередитися на зміні принципових засад функціонування стандартизації: застосуванні стандартів міжнародних організацій; широкому застосуванні принципу добровільності в технічній сфері, але жорсткому застосуванні обов'язковості у безпековій; уніфікації понятійно-змістовного апарату національного законодавства. У зв’язку з цим запропоновано такі зміни до законодавства України:

«1. До Закону України «Про стандартизацію»:

1) п. 22 ст. 1 викласти у новій редакції: «стандартизація - діяльність, яка здійснюється через взаємний вплив суб'єктів господарської діяльності, держави та інших зацікавлених осіб один на одного для досягнення оптимального поєднання ринкового саморегулювання та державного регулювання 3 метою захисту економічних і безпекових інтересів держави, суспільства та окремих споживачів шляхом установлення та застосування вимог для загального та неодноразового використання»;

2) ч. 2 ст. 16 викласти у новій редакції та доповнити реченням: «2. Стандарти, кодекси усталеної практики, технічні умови та інші нормативнотехнічні документи, прийняті підприємствами, установами та організаціями, застосовуються на добровільній основі. Договорами чи в інший спосіб може бути передбачено здійснення добровільної оцінки відповідності продукції цим вимогам».

2. До Закону України «Про технічні регламенти та оцінку відповідності»:

1) абз. 36 ч. 1 ст. 1 доповнити реченням «Технічне регулювання є частиною національної системи стандартизації»;

2) ч. 2 ст. 11 викласти у новій редакції: «Відповідність продукції вимогам технічних регламентів може бути забезпечена шляхом застосування національних 
стандартів, технічних специфікацій та/або інших нормативно-технічних документів, посилання на які містяться у відповідних технічних регламентах. У технічному регламенті зазначається, чи $€$ відповідність продукції таким національним стандартам, технічним специфікаціям та/або іншим нормативнотехнічним документам єдиним способом чи одним із способів задоволення відповідних вимог технічного регламенту»;

3) ст. 24 доповнити новою частиною: «4. Виробник чи інший суб’єкт господарювання має право застосовувати процедури оцінки відповідності шляхом складання документа про відповідність та/чи шляхом розміщення відповідної інформації на офіційній сторінці в мережі Інтернет. У такому разі суб’єкт господарювання бере на себе відповідальність за відповідність продукції вимогам, зазначеним у документі про відповідність та/чи розміщеним на офіційній сторінці в мережі Інтернет».

Ключові слова: стандартизація, технічне регулювання, технічні норми, засіб регулювання господарської діяльності, склад господарського правопорушення, технічні бар'єри у торгівлі, стандарти ISO, європейські стандарти.

\section{SUMMARY}

Popovych T. G. Standardization as a means of regulating economic activity. - Qualifying scientific work as a manuscript.

Thesis for the degree of Candidate of Science of Law on specialty 12.00.04 «Economic Law, Economic Procedural Law». - The Academician F. H. Burchak Scientific-Research Institute of Private Law and Entrepreneurship of National Academy of Law Sciences of Ukraine, Kyiv, 2018.

The dissertation is one of the first in Ukraine standardization studies from the standpoint of science-based analysis of the formation of economic law in Ukraine and the world and the possibilities of applying standardization as a universal means of regulation of economic activity. In the position paper proposes the relationship of economic relations (creating markets for sales of goods and services) with the 
appearance of established rules gradually transformed into demands on quality, quantity and characteristics of technological products and services. These requirements were initially and now voluntary. Only putting them into effect acts of legislation is binding. The development of economic activity and the spread of globalization in society led to a gradual transition from a technical understanding of standardization to security, focusing on activities of the participants of economic relations to meet the interests of end consumers and away from obsession standardization requirements in one country and the transition to requirements used international economic organizations and / or regional associations (collective subjects of international law).

The research was conducted in conjunction with the use of modern methods of scientific knowledge and comparative studies and advances of commercial law, allowing to get rid of unilateralism in the study of the object, but also takes into account all significant (important) aspects and relations on economic activity, seen through the prism of standardization its importance for this activity and its impact on the relationship that gives rise to such activities.

The study author formulated and proved a number of provisions, conclusions and suggestions, which have elements of scientific innovation. It is proposed to define standardization as a type of activity characterized by the following features: a) is carried out through the mutual influence of economic entities, state (its bodies) and other interested persons on each other; b) provides an optimal combination of market selfregulation and state regulation; c) the purpose is to protect the economic and security interests of the state, society and individual consumers; d) establish (as a manifestation of the static state) and apply (as a manifestation of the dynamic state) requirements for general and repeated use.

The author proved that standardization as a means (instrument) regulation of economic relations has universal application, since its requirements: a) influencing all economic relations; b) create conditions for their emergence and implementation; c) provide the opportunity to translate social (extra-legal) standards in the legal field; d) in the case of non-compliance or failure is the basis for the emergence of legal protection. 
It has been proved that standardization has two components: technical and security. The technical component provides the activities of the business entity for the manufacture of goods and / or the provision of services of the appropriate quality. Security - creates conditions that entity to take into account the public interest and / or individual, but also ensures the safety of the environment, state and / or end users.

The author carried out the classification of subjects of standardization in economic law from the point of view of their participation in processes or activities of standardization, regardless of the form of ownership and their belonging to different categories (types) of legal (physical) persons: 1) entities that create standards or other requirements of standardization; 2) entities engaged in economic activities using standards or other standardization requirements; 3) subjects confirming the conformity of goods (services) to standards or other requirements of standardization; 4) entities that monitor compliance with standards or other standardization requirements.

The correlation between the concepts of "standardization" and "technical regulation" (as activity) is established as ancestral and specific concept respectively. The concept of "technical norm" is improved, which, in contrast to the position on its technical (extra-legal) nature, equates to a mandatory rule of conduct in a society that is objectively determined by the level of technology and is used in industry for the maintenance and use of natural objects or artificial origin in order to meet the needs of man and / or the interests of society.

In the investigation of security relations, the following warehouses of economic offenses in the sphere of standardization were found: a) non-compliance with requirements (in case of imperative compliance with the requirements of normative and technical documents on standardization, any violation or non-fulfillment of one of these requirements leads to non-compliance); b) non-fulfillment of requirements (discretion, freedom of choice and availability of behavioral variants in fulfilling the requirements of normative and technical documents on standardization in case of violations of the chosen behavior leads to the emergence of liability).

It has been established that the procedure for confirmation of conformity depends 
on the will of the subjects of standardization, and therefore it should be defined as an optional (additional) type of standardization activity that may complete the process of implementation or create preconditions for liability for economic entities.

Generalization and systematization of world trends approaches to standardization as a means of regulating economic activity in various countries provided an opportunity to develop practical recommendations on: the need to reduce the volume of state regulation of economic activity with the maximum application of self-regulation in the formation and application of standardization requirements; creation of conditions and legislative grounds for the application of external control over the implementation of economic activities with the application of security standardization requirements; improvement of the quality of goods (services) by introducing as requirements of standardization of scientific and technical achievements that were used (tested) for more than four years.

The author proposes to focus on changing the fundamental principles of the functioning of standardization: the application of standards of international organizations; the broad application of the principle of voluntariness in the technical sphere, but the rigorous application of compulsory security; the unification of the conceptual and informative apparatus of the national legislation. In connection with this, the following changes to the legislation of Ukraine are proposed:

"1. To the Law of Ukraine "On Standardization":

1) Clause 22 of Art. 1 in the new wording: "standardization - activities carried out through the mutual influence of economic entities, state and other stakeholders on each other to achieve the optimal combination of market self-regulation and state regulation in order to protect the economic and security interests of the state, society and individual consumers through the establishment and application of requirements for general and repeated use ";

2) Part 2 of Art. 16 a new wording and complement sentence: "2. Standards, codes of good practice, specifications and other normative and technical documents adopted by enterprises, institutions and organizations are applied on a voluntary basis. 
Contract or otherwise may be provided by the voluntary conformity assessment of these requirements"

2. To the Law of Ukraine "On Technical Regulations and Conformity Assessment":

1) paragraph 36 of Part 1 of Article 1 of the complement sentence "Technical regulation is part of the national standardization system";

2) Part 2 of Art. 11 to read in the new wording: "The conformity of production with the requirements of technical regulations may be ensured through the application of national standards, technical specifications and / or other normative and technical documents, references to which are contained in the relevant technical regulations. The technical regulation specifies whether the product corresponds to such national standards, technical specifications and / or other normative and technical documents in the only way or one of the ways to meet the relevant requirements of the technical regulations ";

3) Art. 24 add a new paragraph: "4. The manufacturer or other entity has the right to apply conformity assessment procedures by drawing up a compliance document and / or by placing relevant information on the official web page. In this case, the entity assumes responsibility for the compliance of the product with the requirements specified in the compliance document and / or posted on the official web page. "

Keywords: standardization, technical regulation (as activity), technical norms, regulation of economic activity, composition of economic legal violations, technical barriers to trade, ISO standards, European standards.

\section{СПИСОК ПУБЛІКАЦІЙ ЗДОБУВАЧА}

Статті у вітчизняних наукових фахових виданнях:

1. Попович Т. Г. Зміна правових засад у сфері технічного регулювання в Україні відповідно до вимог СС // Приватне право і підприємництво. Вип. 16. 2016. C. $141-144$.

2. Попович Т. Г. Господарська діяльність в умовах дії Угоди про асоціацію 
України з СС // Приватне право і підприємництво. 2017. Вип. 17. С. 152-156.

3. Popovych T. G. International vision of standardization as a means of regulating economic entities of terms of instability and globalization // Приватне право i підприємництво. 2018. Вип. 18. С. 185-190.

4. Попович Т. Г. Стандартизація чи технічне регулювання: вдосконалення понятійного апарату господарського права на основі міжнародного досвіду // Юридична Україна. 2018. № 1-2. С. 59-65.

Статті у наукових періодичних виданнях інших держав та виданнях, які включено до міжнародних наукометричних баз:

5. Popovich T. G. Standardization in the mechanism of legal regulation of business activity // Сборник научных трудов SWORLD. 2013. Vol. 46. № 4. P. 58-61. ISSN: 2224-0187. ID=21110426.

\section{Опубліковані прачі,} які додатково відображають наукові результати дисертаиії:

6. Попович T. Г. Екологічний менеджмент акціонерних товариств: економіко-правовий аспект // Корпоративне право в Україні: становлення та розвиток. Збірник наукових праць. К., 2004. С. 228-233.

7. Попович Т. Г. Європейський Союз: перспективи для українських підприємств // Нормативно-правове забезпечення євроатлантичної інтеграції України. Вип. 1. К., 2004. С. 159-161.

8. Попович Т. Г. Визначення критеріїв ефективності стандартів у сфері охорони довкілля // Приватне право і підприємництво. Вип. 4. 2005. С. 183-188.

9. Попович Т. Г. Екологічно безпечне житло: реалії та правове регулювання. K., 2006. 32 c.

10. Попович Т. Г. Впровадження стандартизації в господарській діяльності як прояв захисту суб'єктивних цивільних прав // Проблеми здійснення та захисту суб’єктивних цивільних прав: збірник наукових праць. К., 2012. С. 148-150.

11. Попович Т. Г. Додаткові елементи механізму правового регулювання 
стандартизації в господарському праві // Актуальні проблеми реформування земельних, аграрних та господарських відносин. Хмельницький, 2013. С. 424-427.

12. Попович Т. Г. Регулювання господарської діяльності 3 допомогою стандартизації на основі принципу добровільності // Діалектика публічних і приватних інтересів у державному регулюванні економіки. К., 2013. С. 176-181.

13. Попович Т. Г. Особливості застосування стандартизації в умовах набуття чинності Угодою про асоціацію між Україною та ЄС // Проблеми модернізації приватного права в умовах євроінтеграції. Хмельницький, 2015. C. $188-194$.

14. Попович Т. Г. Міжнародно-правові основи стандартизації як засобу регулювання господарської діяльності // Міжгалузеві зв'язки цивільного, господарського та трудового права: [у 2-х част.]. Ч. 1. Кривий Ріг, 2017. С. 183-187.

15. Попович Т. Г. Правові аспекти приведення у відповідність до вимог ЄС системи технічного регулювання у сфері господарської діяльності в Україні // Забезпечення міжнародної приватноправової інтеграційної стратегії. К., 2017. C. $156-172$.

16. Попович Т. Г. Співвідношення стандартизації та технічного регулювання у господарському праві // Збірник праць XII аспірантських та магістерських читань «Актуальні проблеми розвитку України у контексті сучасних світових тенденцій» (23 листопада 2017 року, м. Київ). К., 2018. С. 122-128.

17. Попович Т. Г. Стандартизація як засіб регулювання господарської діяльності: монографія. К., 2018. 224 с. 


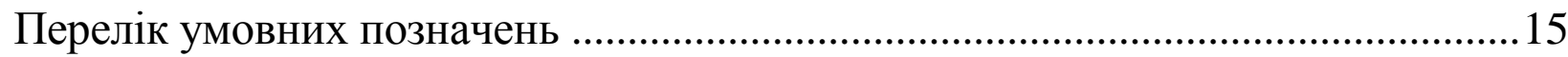

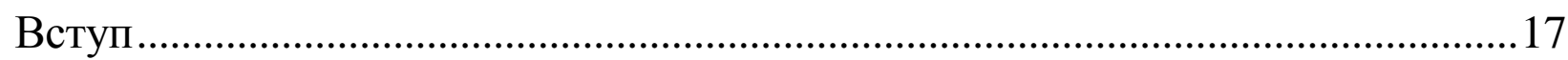

Розділ 1. Основні етапи становлення та розвитку наукової думки про стандартизацію та її вплив на регулювання господарської діяльності.......24

1.1 Історичні передумови виникнення та розвитку стандартизації в контексті поширення знань (інформації), товарів та послуг в ході

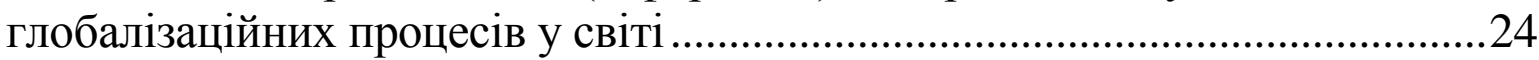

1.2 Розвиток на міжнародному рівні знань про стандартизацію та іii

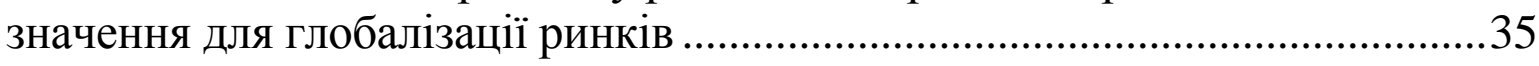

1.3 Формування правових засад та наукових розробок про стандартизацію в Україні ..................................................................................42

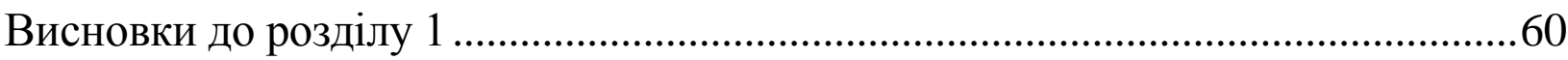

Розділ 2. Стандартизація: поняття, зміст та акти регулювання ....................63

2.1 Поняття та зміст стандартизації..............................................................63

2.2. Акти регулювання у сфері стандартизації ...............................................8 84

Висновки до розділу 2 ....................................................................................113

Розділ 3. Особливості правового режиму стандартизації та правового статусу її суб'сктів........................................................................................................................118

3.1. Особливості стандартизації як засобу впливу на господарську

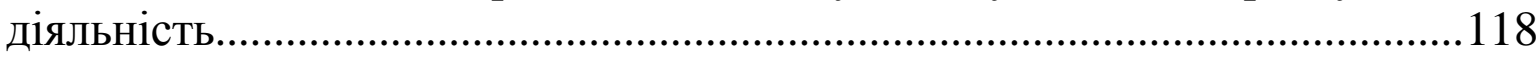

3.2. Особливості стандартизації при впорядкуванні господарських

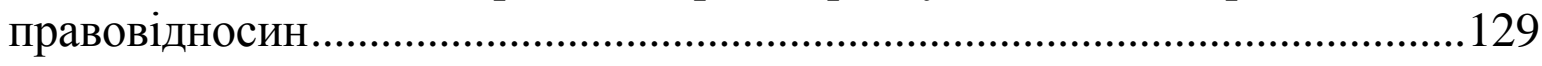

3.3. Особливості правового статусу суб'єктів стандартизації ....................147

3.4. Особливості господарсько-правової відповідальності за невиконання (недотримання) вимог стандартизації при здійсненні господарської

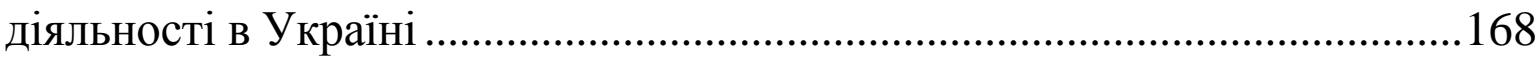

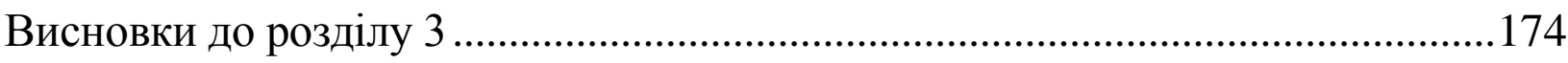

Розділ 4. Міжнародний досвід регулювання відносин з допомогою стандартизації. 180

4.1. Правовий режим Міжнародної організації стандартизації,

Європейського комітету зі стандартизації та їх роль в усуненні

бар'єрів у торгівлі 
4.2. Організаційно-правові засади стандартизації у деяких країнах Європи

4.3. Саморегулівні засади стандартизації в Канаді та їі вплив на розвиток міжнародної стандартизації....

4.4. Пропозиції щодо вдосконалення національної правової системи України у сфері стандартизації 201

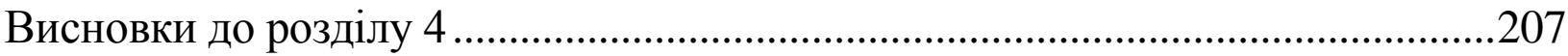

Висновки ................................................................................................................................................211

Список використаних джерел......................................................................................215

Додаток А. Список публікацій здобувача за темою дисертації та відомості про апробацію результатів дисертації. .244

Додаток Б. Акти впровадження результатів дисертації.................................247

Додаток В. Проект Закону України..............................................................................250 


\section{Перелік умовних позначень}

АСЕАН - Асоціація держав Південно-Східної Азії (англ. Association of SouthEast Asian Nations, ASEAN)

ГАТТ - Генеральна угода з тарифів і торгівлі

ГК України - Господарський кодекс України

ГМО - генетично модифікований організм

ГОСТ - Державний стандарт СРСР (рос. Государственный стандарт)

ДК - державний класифікатор

ДП - державне підприємство

ДСТУ - Державний стандарт України

САВТ - Свропейська асоціація вільної торгівлі (англ. The European Free Trade Association)

ЄК - Свропейська комісія

$€ \mathrm{C}-$ Свропейський Союз

ICO - Міжнародна організація стандартизації (англ. ISO - The International Organization for Standardization)

ITA - Угода про інформаційні технології (англ. Information Technology Agreement) МЕК - Міжнародна електротехнічна комісія (англ. IEC - The International Electrotechnical Commission)

MO3 України - Міністерство охорони здоров’я України

MCE - Міжнародний союз електрозв'язку (англ. International Telecommunication Union)

НАССР (ХАССП) - Аналіз небезпеки та критичні контрольні точки (Hazard Analysis and Critical Control Points)

ООН - Організація Об’єднаних Націй

СНД - Співдружність Незалежних Держав

СОТ - Світова організація торгівлі

СРСР - Союз Радянських Соціалістичних Республік

США - Сполучені Штати Америки

ТM - торгова марка

ТУ - технічні умови 
УкрНДНЦ - Український науково-дослідний і навчальний центр проблем стандартизації, сертифікації та якості (Українське агентство зі стандартизації, УАС)

УРСР - Українська Радянська Соціалістична Республіка

CAF - загальний оціночний зріз (англ. The Common Assessment Framework)

CASCO-Комітет 3 оцінки відповідності (англ. Committee on Conformity Assessment)

CEN - Свропейський комітет стандартизації (фр. Comité Européen de Normalisation)

CENELEC - Свропейський комітет зі стандартизації в галузі електротехніки та електроніки (англ. European Committee for Electrotechnical Standardization)

CESA CSA) - Канадська асоціація технічних стандартів (англ. The Canadian Electrical Stewardship Association)

COPOLCO - Комітет з питань споживчої політики (англ. Committee on Consumer Policy)

DEVCO - Комітет підтримки країн, що розвиваються (англ. A committee to support developing countries)

EN - європейський стандарт (англ. European Standard)

ETSI - Свропейський інститут зі стандартизації у галузі телекомунікацій (англ. European Telecommunications Standards Institute)

GMBH (LTD) - товариство 3 обмеженою відповідальністю (нім. Gesellschaft mit beschränkter Haftung, англ. Limited)

JTC1 - Об’єднаний технічний комітет № 1 (англ. Joint Technical Committee 1)

OHSAS - Система менеджменту професійної безпеки та здоров'я (англ.

Occupational health and safety management systems)

PAS - Публічно доступна специфікація (англ. Publicly Available Specification)

PDCA - цикл Шугарта-Демінга (плануй (англ. Plan), роби (англ. Do), перевіряй (англ. Check), впливай (англ. Act)

SGS - Загальне товариство зі спостереження (фр. Société Générale de Surveillance)

STACO - Комітет з вивчення наукових принципів стандартизації (англ. Committee on standardization principles)

TC - технічний комітет (англ. Technical Committee) 


\section{ВСТУП}

Обгрунтування вибору теми дослідження. На сьогодні питання регуляторної політики держави для забезпечення за допомогою права публічних та приватних інтересів є складовою економічної основи господарської діяльності і держави в цілому. Правова основа національної системи стандартизації України створювалася в умовах переходу до ринкової економіки, за нестабільної економічної та фінансової ситуації. Вона формувалася на розгалуженій системі стандартизації колишнього СРСР з урахуванням багатовекторної зовнішньої політики, спрямованої на членство у Світовій організації торгівлі, інтеграцію України до Європейського Союзу, співробітництво з іншими країнами світу. Поєднання цих векторів спричинило суттєві складнощі при застосуванні вимог стандартизації суб'єктами господарських відносин. Значного навантаження додало введення у законодавство нової термінології 3 питань технічного регулювання, оцінки відповідності тощо 3 одночасним виключенням стандартизації 3 переліку засобів державного регулювання господарської діяльності (ст. 12 ГК України). Водночас стандартизація як один із проявів суспільно-економічної формації активно впливає на усунення технічних бар'єрів у торгівлі, розвиток і стан суб'єктів господарської діяльності.

Все це зумовлює необхідність дослідження стандартизації 3 позиції іiі впливу на господарське право, виходячи з теоретико-правових засад та підходів, що застосовуються на міжнародному рівні та/чи в окремих країнах, що вже $\epsilon$ учасниками глобалізованих ринків. У науковій літературі деякі питання стандартизації як явища, процесу та засобу реалізації політики держави у сфері правового забезпечення господарювання вже були предметом дослідження у наукових працях О. А. Беляневич, А. Г. Бобкової, М. І. Брагінського, С. Н. Братуся, О. М. Вінник， I. А. Гамбург, М. Д. Гінзбург, І. Д. Губарєва, В.В.Добровольської, М.Б.Смельянової, І. Є. Замойського, І. С. Канзафарової,
А. С. Комарова,
Д. Х. Липницького,
М. С. Малєїна,
В. К. Мамутова, 
Ю. Г. Матвєєва, Л. Р. Левчук, В. М. Огризкова, В. Ф. Опришка, О. О. Отраднової, Д. І. Сакояна, І. А. Сікорської, Л. Д. Руденко, В. С. Щербини, Л. І. Ярославського та ін. Разом з тим низка теоретичних питань щодо сутності стандартизації, іiі прояву і значення як засобу регулювання господарської діяльності залишаються дискусійними й потребують розгорнутого дослідження.

Зв'язок роботи з науковими програмами, планами, темами, грантами. Роботу виконано відповідно до плану науково-дослідних робіт Науководослідного інституту приватного права і підприємництва імені академіка Ф. Г. Бурчака Національної академії правових наук України за темами «Правове забезпечення регіональних інтеграційних стратегій України в контексті модернізаційної політики держави» (№ державної реєстрації 0113U001118), «Інституційно-правове забезпечення майнових інтересів держави та суб’єктів приватного права в умовах регіональної нестабільності» (№ державної реєстрації 0117U002141), «Приватноправові проблеми реалізації євроінтеграційної стратегії України» (№ державної реєстрації 0117U002140), в межах яких досліджено науково-теоретичні основи стандартизації, а також іï зміст та значення при усуненні технічних бар'єрів у торгівлі.

Мета і завдання дослідження. Метою дисертаційного дослідження $\epsilon$ виявлення та вирішення теоретичних і практичних проблем стандартизації як засобу регулювання господарської діяльності, а також підготовка пропозицій 3 удосконалення законодавства України на основі міжнародного досвіду. Для цього в дисертаційному дослідженні поставлено такі основні завдання:

- виявити особливості формування теоретичних засад стандартизації у контексті наукознавчого розвитку господарського права для встановлення iї історичного та міжгалузевого взаємозв'язку 3 економічними та іншими суспільними відносинами;

- виявити та уточнити теоретичні засади стандартизації з метою усунення хибного (помилкового) тлумачення співвідношення стандартизації та технічного регулювання в праві України; 
- з'ясувати значення стандартизації у регулюванні господарської діяльності 3 обгрунтуванням iї ролі при саморегулюванні та державному регулюванні;

- виявити учасників господарських відносин, що беруть участь у стандартизації, для їх класифікації;

- виявити особливості відповідальності у сфері стандартизації для визначення iï меж та типів правопорушень у цій сфері;

- узагальнити досвід стандартизації у країнах, що $є$ учасниками світових ринків, для уточнення її змісту як засобу регулювання господарської діяльності;

- обгрунтувати пропозиції щодо удосконалення законодавства про стандартизацію у контексті розвитку господарського права.

Об'єктом дослідження є суспільні відносини, що виникають та реалізуються у сфері стандартизації при регулюванні господарської діяльності.

Предметом дослідження є стандартизація як засіб регулювання господарської діяльності.

Методи дослідження. Теоретичною та методологічною основою дослідження є роботи науковців у сфері теорії стандартизації, про іiі місце та значення у правовому регулюванні господарської діяльності. При дослідженні використовувався історичний метод, що надав можливість виявити закономірності та особливості процесу виникнення стандартизації та іiї впливу на економічні відносини. Діалектичний метод взято за основу для дослідження, 3'ясування та уточнення сучасного поняття та змісту стандартизації. Формальнологічний метод застосовувався при аналізі сучасного стану наукових розробок та законодавства у сфері стандартизації в Україні, а також при розробці пропозицій з удосконалення законодавства у цій сфері. Його також було застосовано при визначенні кола суб’єктів стандартизації та виокремленні видів порушень у цій сфері. Системний метод використано для дослідження стандартизації як засобу регулювання господарської діяльності та визначення ії місця серед державних засобів регулювання. Із спеціальних методів використано порівняльно-правовий 
метод, за допомогою якого виявлено позитивний вплив положень міжнародноправових актів, актів законодавства СС та інших країн на міжнародну систему стандартизації, а також можливості імплементації цих положень в національну систему права.

Наукова новизна отриманих результатів полягає в тому, що дисертація $є$ одним із перших в Україні досліджень стандартизації як засобу регулювання господарської діяльності. Сформульовано та обгрунтовано низку наукових положень, які мають ознаки новизни та виносяться на захист:

Уперие:

1) визначено, що стандартизація є видом діяльності, що характеризується такими ознаками: а) здійснюється через взаємний вплив суб'єктів господарської діяльності, держави (iї органів) та інших зацікавлених осіб один на одного; б) забезпечує оптимальне поєднання ринкового саморегулювання та державного регулювання; в) метою є захист економічних і безпекових інтересів держави, суспільства та окремих споживачів; г) установлює (як прояв статичного стану) та застосовує (як прояв динамічного стану) вимоги для загального та неодноразового використання;

2) обгрунтовано, що стандартизація як засіб (інструмент) регулювання господарських відносин має універсальне застосування, оскільки іiі вимоги: а) здійснюють вплив на усі господарські відносини; б) створюють умови для їх виникнення та реалізації; в) надають можливість переводити соціальні (позаправові) норми у правове поле; г) у разі недотримання чи невиконання $\epsilon$ підставою для виникнення охоронних правовідносин;

3) доведено, що стандартизація має дві складові частини: технічну та безпекову. Технічна складова забезпечує діяльність суб'єкта господарської діяльності 3 виготовлення товарів та/чи надання послуг відповідної якості. Безпекова - створює умови для того, щоб вказаний суб'єкт враховував інтереси суспільства та/чи окремої людини, а також забезпечував безпеку довкіллю, державі та/чи кінцевим споживачам; 
4) класифіковано суб'єктів стандартизації в господарському праві з позиції ïx участі у процесах чи діяльності зі стандартизації, незалежно від форми власності та належності їх до різних категорій, на тих, що: а) створюють стандарти чи інші вимоги стандартизації; б) здійснюють господарську діяльність та використовують стандарти чи інші вимоги стандартизації; в) підтверджують відповідність товарів (послуг) стандартам чи іншим вимогам стандартизації; г) контролюють дотримання стандартів чи інших вимог стандартизації;

5) встановлено співвідношення в національному законодавстві понять «стандартизація» та «технічне регулювання» як різнорівневих понять (родового та видового відповідно).

\section{Удосконалено:}

6) поняття «технічна норма», яке, на відміну від поширеної думки про iï технічну (позаправову) природу, прирівнюється до обов'язкового правила поведінки у суспільстві, що об'єктивно визначається рівнем техніки та використовується у промисловості для обслуговування та використання об’єктів природного чи штучного походження з метою задоволення потреб людини та/чи інтересів суспільства;

7) положення про абсолютну господарсько-правову відповідальність у сфері стандартизації шляхом визначення іiі видом охоронних правовідносин, що виникають на підставі порушень законодавчо визначених та/чи договірних, у тому числі задекларованих вимог до товарів та/чи послуг.

Дістало подальшого розвитку:

8) положення про те, що процедура підтвердження відповідності залежить від волі суб'єктів стандартизації, а тому ï слід визначати як необов'язковий (додатковий) вид діяльності зі стандартизації, що може завершити процес правореалізації або створити передумови для настання відповідальності для суб' єктів господарської діяльності;

9) узагальнення світових тенденцій та систематизація підходів щодо стандартизації як засобу регулювання господарської діяльності в різних країнах 
надавали можливість розробляти практичні рекомендації щодо:

- необхідності зменшення обсягу державного регулювання господарської діяльності з максимальним застосуванням саморегулювання при формуванні та застосуванні вимог стандартизації;

- створення умов та законодавчих підстав для застосування зовнішнього контролю за здійсненням господарської діяльності із застосуванням безпекових вимог стандартизації;

- підвищення якості товарів (послуг) шляхом впровадження як вимог стандартизації науково-технічних досягнень, що використовувалися (апробовувалися) понад чотири роки.

Практичне значення отриманих результатів полягає в тому, що вони становлять як науково-теоретичний, так і практичний інтерес та можуть бути використані: у науково-дослідній сфері - за основу для подальшого дослідження стандартизації у господарському праві, компаративістиці та суміжних галузях знань; у правотворчості - в ході внесення змін і доповнень до нормативноправових актів, що регламентують господарську діяльність та усувають технічні бар'єри у торгівлі; у правозастосовній діяльності - 3 метою покращення практичної діяльності суб'єктів господарської діяльності.

Особистий внесок здобувача. Дисертація є самостійною науковою працею, в якій висвітлено авторські пропозиції щодо стандартизації як засобу регулювання господарської діяльності. Викладені в дисертації наукові положення, висновки і рекомендації, що виносяться на захист, отримані дисертанткою самостійно.

Апробація матеріалів дисертації. Підсумки розроблення проблеми в цілому, окремих її аспектів, одержані узагальнення і висновки було оприлюднено на: засіданнях вченої ради Науково-дослідного інституту приватного права i підприємництва імені академіка Ф.Г. Бурчака НАПрН України, науковопрактичних конференціях «Становлення та розвиток корпоративного права» (м. Івано-Франківськ, 26-27.09.2003), «Нормативно-правове забезпечення 
процесів євроатлантичної інтеграції України» (м. Київ, 24.09.2004), «Актуальні проблеми реформування земельних, аграрних та господарських відносин» (м. Хмельницький, 17-18.05.2013), «Проблеми модернізації приватного права в умовах євроінтеграції» (м. Хмельницький, 2-3.10.2015), «Міжгалузеві зв'язки цивільного, господарського та трудового права» (м. Кривий Ріг, 28.09.2017), наукових круглих столах «Проблеми здійснення та захисту суб’єктивних цивільних прав» (м. Київ, 5-6.10.2012), «Діалектика приватних і публічних інтересів в державному регулюванні господарської діяльності» (м. Київ, 08.11.2013), аспірантських та магістерських читаннях «Актуальні проблеми розвитку України у контексті сучасних світових тенденцій» (м. Київ, 23.11.2017).

Структура та обсяг дисертації. Дисертація складається зі вступу, 4 розділів, що охоплюють 12 підрозділів, висновків, списку використаних джерел і 3 додатків. Загальний обсяг дисертації - 256 сторінок. 
РОЗДІЛ 1

\section{ОСНОВНІ ЕТАПИ СТАНОВЛЕННЯ ТА РОЗВИТКУ НАУКОВОЇ ДУМКИ ПРО СТАНДАРТИЗАЦЮЮ ТА ЇЇ ВПЛИВ НА РЕГУЛЮВАННЯ ГОСПОДАРСЬКОЇ ДІЯЛЬНОСТІ}

\section{1 Історичні передумови виникнення та розвитку стандартизації в контексті поширення знань (інформаціі), товарів та послуг в ході глобалізаційних процесів у світі}

Розвиток стандартизації розпочався разом із технічним удосконаленням життя у людському суспільстві. Люди весь час намагалися уніфікувати міри, побутові речі, будівлі тощо. Тому з'явилася нагальна потреба у відборі та фіксуванні окремих (найбільш вдалих) результатів трудової діяльності з метою їх повторного використання. Таке повторення одного й того самого зразка було дуже зручним при поширенні технологій та товарів по всьому світу. Численними є різноманітні приклади зародження елементів стандартизації, що з'явилися в осередках давніх цивілізацій (Китаї, Стародавній Греції, Єгипті). Ними стали створення мови, писемності, грошових одиниць, систем звітності та мір і ваг, одноманітне та взаємозамінне озброєння, частини будівель та інших конструкцій. Часто у різних історичних джерелах згадуються хети, які вперше ввели так звані стандартизовані будівлі, а параграфами 229 і 232 ввели покарання за недотримання будівельних норм [252, с. 41; 260, с. 14]. Як свідчить історичний досвід, такі нововведення мали вагоме підгрунтя, яке і спричинило встановлення стандартизованих методів будівництва та полегшення зведення нових споруд [68].

На території України населення традиційно займалося орним землеробством. Часто земельні ділянки використовувалися навіть до повного виснаження. 3 часом з'явилися так звані народні закони щодо раціонального використання землі, надання 
ій «відпочинку» та застосування сівозмін. Поряд із цим вдосконалювалися знаряддя праці, що полегшувало землеробство (спочатку землероби використоввали дерев'яне рало, а потім - плужне рало із залізним наральником, яке збільшувало глибину оранки до 10-15 см для перевертання підрізаного пласта, а для збору врожаю типові серпи). Поряд із землеробством розвивались інші галузі господарства, де використовувалися стандартизовані виміри (ковальство, гончарство, виробництво борошна, обробка дерева, каменя, шкіри, столярство, будівництво) [226, с. 31]. На давній території України, зокрема на Кримському півострові, ще в VI-I ст. до н. е. існували різноманітні системи одиниць вимірювання. Наприклад, у Херсонесі, Боспорі, Керкинитиді існували свої системи одиниць вимірювання, які були пов’язані з відповідними системами давньогрецьких міст-полісів [112, с. 105-106].

В Україні елементи стандартизації розвивалися і в Середньовіччі. Так, у Київській Русі перші з відомих історикам писемних свідчень про уніфікацію мір і ваг містить Статут Святого князя Володимира, що хрестив Руську землю, про церковних суддів (996 р.) [260, с. 35-36]. У ньому серед обов'язків єпископа, зокрема, відображено: «15. Поручено святым пискупьям городськыя и торговые мерила и спуды, извесы, ставила блюсти без пакости, ни умалити, ни умножити». По суті, цей Статут є документальним підтвердженням того, що вітчизняна стандартизація i метрологія існує вже понад 1000 років. Довгі pp. «стандартизаторами» торгових мір і ваг були монастирі та церкви. Церковні старости та виборні особи від гільдій (цехів) купців стежили за правильністю вимірювань, за збереженням і правильністю мір. На вагах для надання їм законності зазначалися імена князів і назви міст [226, с. 30-32; 267, с. 40].

3 приходом литовської держави на територію Київської Русі дотримувалися правила «ми старину не рушимо, а новину не вводимо». Проте пізніше унія Литви 3 Польщею докорінно змінила історію розвитку права українських земель, що призвело до занепаду власної правової системи, а відтак і до нівелювання досягнень у сфері стандартизації. Хоча у Рішенні Люблінського сейму про об’єднання Польщі та Литви в одну державу - Річ Посполиту (1569 р.) було 
сказано, що монета має бути одноманітна, однакова по вазі та пробі, поділу та напису [260, с. 71], тобто стандартизована.

У першій половині XV ст. феодали-шляхтичі розвивали різні напрями господарської діяльності (влаштовували у власних маєтностях ремісничі майстерні, мануфактури, млини, розвивали інші промисли), але протекціоністська політика держави щодо шляхти мала негативні наслідки: гальмувався розвиток міст, натуральне господарство перешкоджало утворенню єдиного загальнодержавного внутрішнього ринку як основи політичної централізації i, відповідно, не було єдиних правил і вимог до виробів та послуг. Основні категорії міського населення об’єднувалися в цехи: будівельників, шевців, лікарів, зброярів, золотарів тощо. На вершині цехової ієрархії перебували цехмайстри, які за можливості стежили за дотриманням стандартів і вимог, за якістю та кількістю продукції [89, с. 68-70].

3 кінця XV - початку XVI ст. починається тенденція приєднання українських земель до Московської держави, яка згодом стала Російською імперією. Як відомо, вона завершилася в кінці XVIII ст. абсолютно новою геополітичною конфігурацією: переважна частина етнічних українських земель (до 80 \%) увійшла до складу Російської імперії. На цих українських землях поступово поширюються всі суспільно-економічні трансформації, характерні для Росії, у тому числі запроваджуються елементи стандартизації [89, с. 106-110; 226, c. 30-32]. На територіях, що не увійшли на той час до Московії, розвиток стандартизації відбувався відповідно до законодавства тієї країни, яка панувала на цих землях. Так, у 1764 році Конституцією Польщі на Правобережній Україні та Галичині запроваджено загальнодержавні одиниці довжини, маси та об'єму. 31 березня 1875 р. австрійський цісар Франц Йосиф видав Указ про організацію установ мір та ваги. За цим Указом зобов'язувалося в усіх землях АвстроУгорської монархії створити державні установи міри та ваги. На його виконання 15 вересня цього самого року було видано розпорядження Міністерства внутрішніх справ і Міністерства фінансів про створення в коронних землях 10-ти 
округів нагляду за мірами та вагою [92; 124, с. 132-134]. Таким чином, можна сказати, що основна увага країн Європи стосувалася ваги та розміру товарів, а питання про якість не ставилося на загальному рівні (лише ім'я та репутація майстра могла свідчити про якість і надавала виробнику конкурентну перевагу на ринку).

Iз створенням централізованої Московської держави великі князі намагалися встановити загальнодержавні міри, що були обов'язковими для використання по всій країні [155, с. 186-188]. Так само, як і в Європі, на території Московської держави основним законодавчо закріпленим мірилом продукції стала вага та розмір, а якість - факультативом, що існував лише в господарській практиці як добре ім'я [226, с. 32].

3 появою нових методів обробки матеріалів та виробництва товарів за допомогою машин (механізмів) у світі розпочинається промислова революція. 3 часів правління Петра I почалася масштабна промислова стандартизація в Росії. Стандартизацію використовували при нормуванні виробництва військової техніки, сільськогосподарської сировини, продуктів харчування, зведенні будинків, а також у будівництві флоту [64, с. 54-55]. Розвиток промисловості та транспорту в Російській імперії призвів до розширення робіт із стандартизації у XIX ст. Впровадження стандартів та єдиних вимог до якості продукції в Російській імперії ускладнювалося через велику кількість іноземних концесій, власники яких, як правило, запроваджували свої стандарти. Зокрема, такий стан справ призвів до поширення в країні трьох систем вимірювання: аршинної, дюймової та метричної. Це, зрозуміло, ускладнювало не лише виробництво продукції, а й контроль їі параметрів [64, с. 56].

Після революції 1917 року нова держава розпочала уніфікувати та стандартизувати усе по-своєму. Становлення науки про стандартизацію розпочалося після усвідомлення радянською владою того, що без установленого порядку неможливо буде здійснювати якісне виробництво у плановому господарстві. Розвиток промисловості потребував уніфікації норм. Зокрема, у 
1929 році на пленумі Ради зі стандартизації при Раді праці та оборони висловлювалася думка, що для магістралізації транспортних мереж та розвитку енергетики необхідно створювати норми та стандарти у швидких темпах [160, с. 16, 19; 282, с. 14-19]. Державницькі мужі розуміли, що для утримання економіки СРСР у цілісному стані та для розвитку суб’єктів господарювання (отримання від них вливань у новостворену державу) необхідно здійснювати єдину уніфіковану стандартизацію продукції, товарів, послуг, методів виробництва, що відносилися до сфери народного господарства.

У роки Другої світової війни розпочався новий сплеск науки та практики стандартизації з метою виготовлення військової техніки у багатьох видах озброєння. Слід зазначити, що на початку Великої Вітчизняної війни в СРСР діяло понад 6000 стандартів, з яких 35\% належало до машинобудівельної та металургійної промисловості (основних галузей промисловості СРСР до війни). За роки війни було затверджено близько 2000 нових стандартів і понад 1000 стандартів набули змін [281, с. 6-8]. Це було зумовлено умовами воєнного часу та необхідністю економії матеріальних ресурсів, заміною дефіцитних матеріалів на менш дефіцитні, впровадженням нових технологій та методів виробництва.

У повоєнні роки в СРСР ретельно вивчався світовий досвід стандартизації [105, с. 14-15]. Перекладалися книги і статті, у журналах друкувалися анотації закордонних публікацій, видавалися їх бібліографії. Випускалася велика кількість популярних видань, широке коло спеціалістів та звичайних споживачів отримували доступ до інформації як із загальних питань стандартизації, так і зі стандартів спеціального призначення. У СРСР в умовах централізованої системи управління народним господарством 3 мінімальною самостійністю підприємств діяла єдина система нормативно-технічної документації, згідно з якою існували три категорії стандартів (державні, республіканські, галузеві), а також ТУ, які затверджувалися державними органами та були обов'язковими для окремих підприємств. Особливого розвитку стандартизація набула в галузях машинобудування, металургії, хімії. Одночасно 3 державною розвивалась 
галузева та місцева (заводська) стандартизація. У 1947 році країна вступила до ISO, але для CPCP та іï̈ системи стандартизації це приєднання не було таким вже важливим. Вступ до цієї організації та використання іiї стандартів зумовлювався лише необхідністю експортувати товари за межі СРСР. Зазвичай навіть на експортовані товари діяли нормативно-технічні документи СРСР, оскільки основними споживачами ставали «країни соцтабору».

Після Другої світової війни розпочався швидкий розвиток народного господарства в СРСР, а технічний прогрес та технологічні прориви в усіх галузях промисловості викликали нові, більш високі вимоги до організації роботи зі стандартизації та правових підстав до їі впровадження та застосування [13, с. 21 $23 ; 82$, c. $3-6 ; 114$, c. $8-10 ; 117$, c. $23-32 ; 141$, c. $67-68 ; 149$, c. $14-15 ; 167$, c. $13-21$; 193 , с. $43-45 ; 209$, с. $91-92 ; 219$, с. $14-24 ; 242$, с. $93 ; 243$, с. $12-14]$. У наступні роки зазнала деяких змін система управління державною стандартизацією. Зростала роль стандартизації як засобу прискорення технічного прогресу, поліпшення якості продукції і створення основи для поширеної спеціалізації виробництва. Розроблялися єдині системи нормативно-технічної, проектно-конструкторської і технологічної документації, міжгалузеві системи, Державна система стандартизації тощо. Особливої уваги заслуговують наукові праці, присвячені розвитку стандартизації у виробничій сфері, особливо в тих галузях, де відбулося зародження стандартів, було здійснено їх теоретичне обгрунтування, методичне та організаційне забезпечення, державне визнання та підтримка. [7, с. 11; 196]. Активно почався розвиток наукової думки про стандартизацію та про необхідність їі правового регулювання з 60-х рр. ХХ ст. [76, с. 33-44; 36, с. 39-49; 67 , с. $50-51 ; 115$, с. $132-138 ; 119$, с. $55-65 ; 217$, с. $66-72]$. 3 часом радянська наука у сфері стандартизації почала займати домінуючі позиції у технічних галузях. Публікації показували реальну користь стандартів і популярно розкривали їхню сутність $[127$, с. $15-18 ; 257$, с. $13-14 ; 265$, с. 10-12]. У цей самий час проводилася роз'яснювальна робота серед працівників. До обговорення стандартів та їх проектів широко залучалися як керівництво, так і рядові робітники. [22; 30, с. 83- 
84; 215 , с. $111-121 ; 221$, с. 85]. Відбувалося перетворення набутого досвіду в галузі стандартизації в практичну діяльність, удосконалилася Державна система стандартизації, яка визначала правила проведення робіт зі стандартизації в країні та прогресивні вимоги до якості продукції [18, с. 3-8; 111, с. 90-94; 147, с. 92-96]. В окремих галузях (озброєння та військова техніка, авіаційно-космічна техніка, суднобудування, залізничний транспорт, атомна енергетика) визначальною стала галузева стандартизація. 3 подальшим розвитком економіки змінюється нормативно-правова база і в цій сфері.

3 подальшим розвитком економіки змінюється нормативно-правова база і в цій сфері. У 1988 році було ліквідовано галузеві нормативно-технічні документи та встановлено два рівні нормативно-технічної документації: державні (республіканські) стандарти та ТУ. При цьому підкреслювалась необхідність забезпечити на практиці право підприємств самостійно затверджувати після погодження із споживачем ТУ, технічні описи, зразки-еталони й іншу аналогічну документацію, що необхідна для випуску продукції. [19; 20, с. 50-53; 26, с. 50-51; $65 ; 77 ; 98$, c. $72-80 ; 100$, c. $10-13 ; 150$, c. $48-52 ; 156$, c. $44-48 ; 165 ; 192$, c. $13-17$; 205 ; 206 , c. $14-16 ; 229$, с. $55-56 ; 237 ; 240$, c. $52-54 ; 253$, c. $66-80 ; 254$, c. 28-30]. У кінці 80-х - на початку 90-х pp. ХХ ст., у перехідний до ринкових відносин період, особливого значення набула робота 3 удосконалення законодавчих засад стандартизації, прийняття нових та переглянутих науково-технічних документів України, гармонізації вітчизняних стандартів з міжнародними тощо [8, с. 6].

Важливо зробити аналіз процесу створення національного законодавства 3 технічного регулювання, адже до сьогодні в Україні діяльність в галузі технічного регулювання регламентувалася близько 100 законами та декретами України, постановами та розпорядженнями Президента України та Кабінету Міністрів України.

Якщо аналізувати етапи правового розвитку української стандартизації, то можна 3 певністю стверджувати, що правові засади вітчизняної стандартизації заклали у 1993 р. Декретом Кабінету Міністрів України «Про стандартизацію і 
сертифікацію» від 10.05 .93 № $46-93$ з наступним схваленням комплексу основоположних стандартів Державної системи стандартизації України (ДСТУ 193), у яких йшлося про систему нормативних документів, адресованих усім користувачам незалежно від їх форми власності. Було вперше встановлено дві категорії стандартизованих положень (обов'язкові та рекомендовані), передбачено поступову заміну чинних нормативно-технічних документів СРСР (усіх рівнів) національними з можливим використанням міжнародних стандартів. Розробку нормативно-технічних документів було доручено вперше створюваним ТC зі стандартизації (як неприбутковим організаціям), якими було запроваджено двомовне викладення тексту нормативно-технічних документів українською та російською мовами.

Наступним кроком удосконалення правової основи стандартизації став Закон України «Про стандартизацію» від 17.05.2001 р. № 2408-III. 3 цього часу ситуація суттєво змінилась, розпочалась активна перебудова системи та загальних засад функціонування національної стандартизації відповідно до принципів, прийнятих у розвинених країнах світу 3 ринковою економікою, хоча вади колишньої планової системи значною мірою залишалися невикорінними (наприклад, неповороткість системи, повільне впровадження новітніх досягнень науки та техніки у виробництво, а також внесення на їх основі змін до нормативно-технічних документів).

У Законі України «Про стандартизацію» було уточнено функції Держстандарту та запроваджено Раду із стандартизації як консультативнодорадчий орган при Уряді, сформульовано вимоги до стандартів, які, зокрема, повинні відповідати ринковим потребам і запобігати введенню в оману споживачів. Пізніше (при внесенні змін) відповідно до практики європейського законодавства (директив СС) акцент зроблено на добровільності застосування стандартів, а також розмежовано положення стандартів i законодавчих нормативно-правових актів (технічних регламентів). Іншими словами, були виокремлені законодавчо регульована та нерегульована сфери використання 
нормативних документів i запроваджено упорядкування першої 3 цих сфер документами нового типу - технічними регламентами. Технічний регламент визначено як нормативно-правовий акт, прийнятий органом державної влади, що встановлює технічні вимоги до продукції, процесів та послуг. Національні стандарти України мали на меті на добровільних засадах забезпечити підвищення конкурентоспроможності та безпечності продукції, робіт і послуг. У разі гармонізації національних стандартів та/чи інших нормативно-технічних вимог 3 вимогами документів СС вони могли ставати доказовою базою дотримання обов'язкових вимог технічних регламентів, тобто реалізовувати «презумпцію відповідності» основним (суттєвим) вимогам технічних регламентів, що їх стосуються. Одночасно з Законом України «Про стандартизацію» було прийнято Закон України «Про підтвердження відповідності» (від 17.05.2001 p. № 2406-III). У ньому 3'явився новий вид нормативно-технічних документів (технічні регламенти 3 підтвердження відповідності), що отримали статус урядового нормативно-правового акта. Було встановлено, що цей нормативно-технічний документ має містити:

опис видів продукції, що підлягає обов'язковому підтвердженню відповідності; вимоги до такої продукції, які мають убезпечувати людей, тварин, рослини, майно і довкілля;

процедури підтвердження відповідності таким вимогам.

На основі нових впроваджень у систему вимог стандартизації в Указі Президента України «Про Державний комітет України з питань технічного регулювання та споживчої політики» від 01.10.2002 p. № 887/2002 було запроваджено (хоч і без конкретизації змісту) нове поняття «технічне регулювання». Пізніше Постановою Кабінету Міністрів України «Про делегування Держспоживстандарту повноважень на затвердження нормативноправових актів» від 26 грудня 2003 р. № 2022 Держспоживстандарту було доручено затвердження технічних регламентів, що суттєво принижувало рівень таких документів, але запроваджувалася необхідність оприлюднення проектів 
нормативно-технічних документів, що створило можливість вільного обговорення їх заінтересованими сторонами. 3 цього часу чітко закріплювалося обов'язкове викладення нормативно-технічних документів лише національною мовою (у разі нагальної потреби - мовою міжнародних та регіональних організацій). Було узаконено вимогу враховувати конкретні ризики для споживачів, довкілля та природних ресурсів, що спричиняють дійсну потребу прийняття нормативнотехнічних документів, та встановлювати у них процедури оцінки відповідності, які до цього існували в системі давно запровадженої сертифікації, але були проігнорованими.

У 2005 p. наявні правові засади доповнено Законом України «Про стандарти, технічні регламенти та процедури оцінки відповідності» від 01.12.2005 p. № 3164-IV (оновлену редакцію прийнято 31.05.2007р.), в якому, нарешті, визначено поняття «технічне регулювання» як правове регулювання відносин у сфері встановлення, застосування та виконання обов'язкових вимог до продукції або пов'язаних 3 нею процесів, систем і послуг, персоналу та органів, а також перевірка їх дотримання шляхом оцінки відповідності та/або ринкового нагляду. Щоб не створювати або не призводити до створення зайвих перешкод у торгівлі, нормативно-технічні документи та процедури оцінки відповідності розробляються на основі:

1) міжнародних та регіональних стандартів, якщо вони вже прийняті або перебувають на завершальній стадії розроблення, за винятком випадків, якщо вони $є$ неефективними або невідповідними з огляду на недостатній рівень захисту або базові кліматичні, географічні умови, технологічні проблеми або особливості держави, умови та суттєві технічні проблеми (якщо міжнародні стандарти не беруться за основу для нормативно-технічного документа, то дається письмове пояснення на запит заінтересованої сторони);

2) стандартів, технічних регламентів та процедур оцінки відповідності, або відповідних їх частин держав, що $є$ членами відповідних міжнародних чи регіональних організацій, або з якими укладено відповідні міжнародні договори 
України (договори про взаємне визнання, розроблення та застосування стандартів, технічних регламентів та процедур оцінки відповідності);

3) наукових досягнень, знань і практики.

Водночас було внесено зміни до Закону України «Про стандартизацію» від 17.05.2001 р. № 2408-111. Було уточнено мету стандартизації в Україні, до якої додано підтримку розвитку та міжнародної конкурентоспроможності продукції в процесі торгівлі товарами і послугами. 3'явилася і нова норма про прийняття i застосування органами стандартизації на території України Кодексу доброчинної практики з розроблення, прийняття і застосування стандартів відповідно до Угоди COT про технічні бар'єри в торгівлі. Разом з тим не було скасовано залишки раніше вже відкоригованого Декрету Кабінету Міністрів України «Про стандартизацію і сертифікацію» від 10.05.1993 р. № 46-93, що втратив цінність як нормативно-правовий документ у цій сфері.

У 2003 році з прийняттям ГК України господарське законодавство офіційно збагатилося новими нормами 3 питань стандартизації (ст. 15). У ньому було подано перелік нормативно-технічних документів, що застосовуються у господарській діяльності: ДСТУ; кодекси усталеної практики; класифікатори; ТУ; міжнародні, регіональні і національні стандарти інших країн (застосовуються в Україні відповідно до чинних міжнародних договорів України).

ГК України також закріпив коло суб’єктів стандартизації, до яких відніс: 1) суб'єктів господарювання, якщо на стандарти $є$ посилання в нормативно-правових актах; 2) учасників угоди (контракту) щодо розроблення, виготовлення чи постачання продукції, якщо в ній (ньому) є посилання на певні стандарти; 3) виробника чи постачальника продукції, якщо він склав декларацію про відповідність продукції певним стандартам чи застосував позначення цих стандартів у іiї маркуванні; 4) виробника чи постачальника, якщо його продукцію сертифіковано щодо вимог стандартів.

Зважаючи вступ України до СОТ, до ГК України вже було внесено деякі застереження [172, с. 143]. На сьогодні в Україні знову відбулися зміни у законодавстві у сфері стандартизації, аналіз яких буде подано нижче. 


\section{2 Розвиток на міжнародному рівні знань про стандартизацію та ії значення для глобалізації ринків}

Як було згадано вище, СРСР вступив до ISO, але не брав активної участі і їі діяльності, оскільки не мав на меті глобалізацію свого ринку та вихід на ринки інших країн світу. Водночас після війни ISO активно розвивається. Заснована у 1947 році $з$ девізом «дружба між рівними» 25 країнами, сьогодні налічує 163 члени. Це членство поділяється на повне, кореспондоване та підписне (детальніше їх буде розглянуто в інших підрозділах).

Важливим є також прослідкувати, коли і які акценти розставляє ISO під час свого розвитку (на основі матеріалів та баз даних офіційного сайту www.iso.org):

1. У 1951 р. опубліковано перший стандарт ISO/R1:1951 щодо стандартної температури для вимірювань промислової довжини. Надалі стандарт був оновлений кілька разів і на сьогодні це ISO 1:2002 Geometrical Specifications (GPS) - Стандартна еталонна температура для геометричної специфікації продукту. Тобто першими кроками ISO стала стандартизація вимог стосовно одиниць та способів вимірювання.

2. У 50-х pp. XX ст. ISO розпочинає також інформаційну роботу і випускає журнал, де публікує інформацію про роботу технічних комітетів, офіційні стандарти, повідомляє про членство.

3. У 1960 р. ISO публікує стандарт ISO 31 щодо кількості та одиниць (сьогодні це ISO 80 000), що засновувався на Міжнародній системі одиниць (SI). SI встановлює одну одиницю для кожної кількості, наприклад, лічильник для відстані, часу тощо. Метою системи SI є досягнення загальносвітової рівномірності одиниць виміру. Стандарт визначає ці одиниці та пояснює, як їх використовувати.

4. У 1961 p. створено DEVCO, а в 1968 році вводиться його кореспондентський склад. Це надає можливість країнам, що розвиваються, бути 
інформованими про роботу з міжнародної стандартизації без повних витрат на членство в ISO. Так само є вигода для розвинених країн, оскільки вони мають змогу поширити свої вимоги на інші країни та розширювати свої ринки. Тобто ми говоримо про зародження глобалізаційних процесів у стандартизації.

5. У 1968 p. ISO публікує свій перший стандарт щодо вантажних контейнерів. Вантажні перевезення та упаковка $є$ однією з сфер, де ISO бкла особливо активною. Уніфікація упаковки та способів переміщення товарів (глобальні логістичні аспекти) надає можливість забезпечити просування товарів по всьому світу.

6. Кінець 60-х pp. ХХ ст. характеризується закінченням «технічного націоналізму». Тобто нівелюється девіз, що виник на початку промислової революції: використання технології як ключового предмета в зміцненні нації для iï впевненості в унікальності інноваційного розвитку країни та гарантії поширення технологій лише серед своїх. Міжнародна стандартизація призводить до необхідності поширення знань та технологій за межі окремих країн.

7. На початку 70-х pp. XX ст. ISO зосереджується на безпекових (довкільних) проблемах. Особливо акцентується увага на якості повітря та води. На сьогодні увага зосереджена на багатьох об’єктах: якості грунту, екологічному управлінні, відновлювальній енергії тощо.

8. У 1987 p. ISO публікує свій перший стандарт з управління якістю. Стандарти серії ISO 9000 поступово стали частиною найвідоміших та найпопулярніших стандартів. Ці стандарти приймаються країнами майже без змін, оскільки у разі застосування символізують високий рівень (клас підприємства) та здатність до конкурентної боротьби.

9. Середина 90-х pp. ХX ст. характеризується розвитком цифрових технологій. ISO не стоїть осторонь, а створює спочатку офіційну сторінку в Інтернеті, а з 2000 р. вже навіть продає стандарти через сайт.

10. У ці самі роки ISO запускає серію стандартів ISO 14000 (системи управління охороною довкілля). Ці стандарти надають інструменти для 
підприємств та організацій, які допомагають виявити та контролювати їх вплив на довкілля.

11. У 2003 p. ISO розширює свою роботу, щоб охопити нові технології, такі як нанотехнології та біопаливо. Тобто ми бачимо, що ISO відслідковує технологічні прориви та допомагає типізувати та уніфікувати інноваційні галузі.

12. У 2005 р. спільний TC ISO та IEC JTC1 запускає ISO / IEC 27001 стандарт системи управління інформаційною безпекою. Підприємства дедалі більше стають залежними від інформаційних технологій, а тому забезпечення вимог для цієї системи та мінімізація ризиків стає важливішим.

13. 32009 р. змінюється організація роботи у комітетах ISO. Швидкий розвиток техніки та технологій потребує прийняття простіших та швидших рішень, а тому виникає необхідність скорочення часу розробки стандартів, що допомагає встановити роль, яку стандарти грають у світі, який швидко розвивається.

14. У 2010 році ISO активно підтримує роботу щодо соціальної відповідальності, що призводить до запуску стандарту ISO 26000. Це перший міжнародний стандарт, що містить керівні принципи соціальної відповідальності. Оскільки соціальна відповідальність стала повсякденною частиною бізнесу, то ISO 26000 зарекомендувала себе як глобальний еталон для організацій, які піклуються про їх вплив на широке коло людей.

15. У ці самі роки світова спільнота задумується над енергоефективністю та енергозбереженням, що є однією з найважливіших проблем, з якими стикається кожен підприємець. ISO вводить стандарт енергоменеджменту ISO 50001, що надає організаціям державного та приватного секторів стратегії управління, спрямовані на енергозбереження, зниження витрат та підвищення енергетичної ефективності.

16. У 2015 р. Фондом OOH спільно з ISO було започатковано координацію міжнародного підходу до побудови надійного ринку чистих кухарів, розробки та застосування стандартів, щоб забезпечити на ринку найкращі кухонні плити та 
паливо. Тобто ISO розширює сферу свого впливу 3 суто технічного до різногалузевого, соціального, безпекового секторів. Нині застосовується девіз «стандарти ISO використовуються скрізь».

17. У 2016 році ISO видає потужний новий інструмент для боротьби 3 світовим лихом - хабарництвом. Стандарт ISO 37001 - це перший міжнародний стандарт системи управління боротьбою з хабарництвом, розроблений з метою допомоги організаціям у боротьбі з ризиком отримання хабарів у власних операціях та у всіх своїх глобальних системах цінних паперів, що має потенціал для зменшення корпоративного ризику та витрат, пов'язаних з хабарництвом, шляхом створення керованої бізнес-системи для запобігання, виявлення та подолання хабарництва.

ISO 37001: 2016 визначає вимоги та надає керівництво для встановлення, впровадження, підтримки, перегляду та вдосконалення системи управління у сфері боротьби з хабарями. Система може бути самостійною або ж інтегрованою в загальну систему управління. ISO 37001: 2016 стосується такої діяльності організації:

- хабарництво в державних, приватних та неприбуткових секторах;

- хабарництво в організації;

- хабарництво персоналу організації, що діє від імені організації або на його користь;

- хабарництво бізнес-партнерів організації, що діють від імені організації або на їі користь;

- хабарництво організації;

- хабарництво персоналу організації стосовно діяльності організації;

- хабарництво бізнес-партнерів організації стосовно діяльності організації;

- прямий та непрямий хабар (наприклад, запропонований чи прийнятий через третю сторону).

ISO 37001: 2016 застосовується лише до хабарництва. Вона визначає вимоги та надає керівництво для системи управління, призначеної для того, щоб 
допомогти організації запобігти, виявити та відповісти на хабарництво та виконувати закони про боротьбу з хабарництвом та добровільні зобов'язання, що застосовуються до іï діяльності. ISO 37001: 2016 спеціально не стосується шахрайства, картелів та інших правопорушень, пов'язаних 3 антимонопольністю/конкуренцією, відмиванням грошей та іншими видами діяльності, пов'язаними з корупцією, хоча організація може вибрати розширення сфери застосування системи управління для включення такої діяльності. Вимоги ISO 37001: 2016 є загальними і призначені для застосування до всіх організацій (або частин організації), незалежно від типу, розміру та характеру діяльності, а також у державних, приватних або неприбуткових секторах. Ступінь застосування цих вимог залежить від різних факторів.

Відштовхуючись від керівних принципів та засад формування стандартизації в ISO, кожна країна формувала власний пакет вимог [292, с. 59-60]. Часто стандарти ISO приймалися (адаптувалися) не лише окремими, а й об’єднаними (колективними) суб'єктами міжнародного права та впроваджувалися у національні системи стандартизації.

Україна має враховувати та орієнтуватися на вимоги стандартизації Свропи, оскільки територіально є iї частиною та перебуває у процесі вступу до ЄС.

Тенденції та основні засади розвитку європейської стандартизації. У часи, коли постало питання про об'єднання країн Свропи, було засновано Європейський комітет 3 координації стандартів, що мав стати центральним органом ЄС у цій сфері. Надалі співвідношення між стандартизацією та законодавством на європейському рівні розроблялося і розробляється CEN (перейменовано в 1970 р.) відповідно до так званого нового підходу до технічної гармонізації та стандартів, яке було запроваджено у 1985 році (тут і нижче аналізується матеріал з офіційного сайту - www.cen.eu). Саме тоді СС ухвалив законодавство (Директиви $\mathrm{CC}$ ), яке визначає основні вимоги щодо безпеки та інших аспектів суспільного інтересу, що мають бути частиною товарів та послуг, які продаються на єдиному ринку. У разі потреби ЄК видає запити на 
стандартизацію (мандати) CEN, CENELEC та ETSI, які відповідають за підготовку технічних стандартів та специфікацій, що полегшують дотримання цих основних вимог. Водночас усі національні органи повинні визнавати, що всі виготовлені товари (та надані послуги) відповідно до гармонізованих стандартів, як передбачається, відповідають основним вимогам, визначеним відповідним законодавством СС. EN від початку були і залишаються добровільними, а тому не існує юридичного зобов’язання щодо їх застосування (EN 45020:2006 Standardization and related activities - General vocabulary (ISO/IEC Guide 2:2004 [11]). Будь-який виробник (або постачальник послуг), який вирішує не дотримуватися гармонізованого стандарту, зобов’язаний довести, що їх продукція (або послуги) відповідає іншим основним вимогам.

На сьогодні CEN є об'єднанням, яке включає в себе учасників та координує національні органи стандартизації 34 європейських країн. CEN є однією з трьох європейських організацій стандартизації (разом 3 CENELEC та ETSI), які офіційно визнані $\mathrm{EC} \mathrm{та} \mathrm{ЕFTА} \mathrm{як} \mathrm{відповідальні} \mathrm{за} \mathrm{розробку} \mathrm{та} \mathrm{визначення}$ добровільних стандартів на європейському рівні. CEN надає платформу для розробки EN та інших технічних документів стосовно різних видів продукції, матеріалів, послуг та процесів. CEN підтримує діяльність з стандартизації в широкому діапазоні галузей та секторів, включаючи: повітря та космос, хімікати, будівництво, споживчі товари, оборону та безпеку, енергетику, навколишнє середовище, продукти харчування та корми, охорону здоров’я, інформаційнокомунікативні технології, машинобудування, матеріали, напірне обладнання, послуги, розумне життя, транспорт, упаковку тощо.

CEN показала і показує, що європейська стандартизація відіграє важливу роль у розвитку та зміцненні європейського єдиного ринку, та й Європи як політичносоціального конгломерату. Показовим є той факт, що кожен EN є визнаним у всій Європі. Крім того, він автоматично стає національним стандартом у 34 європейських країнах, а це надає можливість підприємствам набагато простіше продавати свої товари або послуги споживачам на єдиному європейському ринку. 
CEN разом з CENELEC та ETSI визнана СC як офіційна організація стандартизації. Правова основа цього співробітництва викладена в Положенні СС 1025/2012, яке в остаточній редакції набуло чинності з 1 січня 2013 року [293]. CEN об'єднує знання експертів усіх своїх членів, бізнесу та промисловості, інших зацікавлених сторін та має на меті розробку EN для продуктів, матеріалів, послуг та процесів. Ці EN охоплюють передові технології та інновації. Правильність застосування EN забезпечує якість, продуктивність та сумісність товарів і послуг. Вони допомагають захищати здоров'я та безпеку споживачів та працівників а також довкілля. CEN також прагне підтримувати міжнародну систему стандартизації та тісно співпрацює з ISO за допомогою Віденської угоди про встановлення технічної співпраці між ISO і CEN (Vienna Agreement, 1991 [285]). Метою Віденської угоди є одночасне визнання стандартів на міжнародному і європейському рівнях через кращий обмін інформацією і взаємне представництво на засіданнях, а діяльність зі стандартизації має здійснюватися лише на одному рівні, якщо це взагалі можливо. Нині діє редагована версія цієї Угоди, що надає пріоритет міжнародній стандартизації і придає лідерству ISO більшої ваги, ніж у попередніх версіях. Так, EN, що заснований на стандарті ISO, може переглядатися лише за лідерства ISO попри европейське (первинне) походження.

Україна сьогодні перебуває на шляху до вступу в $Є C$, а тому, поки $є$ час, ми маємо зосередитися на принципових засадах функціонування стандартизації в європейських країнах, вдосконалити власне правове забезпечення стандартизації для усунення технічних бар'єрів у торгівлі та допомогти забезпечити суб'єктів господарської діяльності інформацією про умови роботи на ринках цих країн [170, с. 152-153].

Інформаційне забезпечення, у тому числі з допомогою наукових розробок вітчизняних учених, $€$ основою знань про способи та умови здійснення господарської діяльності не лише в Свропі, а й на інших глобалізованих ринках. Праці вчених $\epsilon$ основою для вдосконалення та розвитку національного законодавства у цій сфері, а також надають можливість зрозуміти вектори зацікавленості суб'єктів різного рівня, форм власності та величини. 


\section{3 Формування правових засад та наукових розробок про стандартизацію в} Україні

Важливо прослідкувати етапи створення національного законодавства зі стандартизації, адже до сьогодні в Україні діяльність у цій сфері регламентувалася близько 100 законами і декретами України, постановами та розпорядженнями Президента України та Кабінету Міністрів України.

У кінці 1980-х - на початку 1990-х рр., у перехідний до ринкових відносин період, особливого значення набула робота з удосконалення законодавчих засад стандартизації, прийняття нових і переглянутих науково-технічних документів України, гармонізації вітчизняних стандартів із міжнародними тощо [8, с. 6].

Правові засади вітчизняної стандартизації закладені у 1993 р. Декретом Кабінету Міністрів України «Про стандартизацію і сертифікацію» від 10.05.93 p. № 46-93 з наступним схваленням комплексу основоположних стандартів Державної системи стандартизації України (ДСТУ 1-93), у яких йшлося про систему нормативних документів, адресованих усім користувачам незалежно від ïx форми власності. Було вперше встановлено дві категорії стандартизованих положень (обов'язкові та рекомендовані), а розроблення нормативно-технічних документів було доручено вперше створюваним ТС зі стандартизації (як неприбутковим організаціям), якими було запроваджено двомовне викладення тексту нормативно-технічних документів - українською та російською.

Наступним кроком удосконалення правової основи стандартизації став Закон України «Про стандартизацію» від 17.05.2001 p. № 2408-III. 3 цього часу ситуація суттєво змінилася, розпочалась активна перебудова системи та загальних засад функціонування національної стандартизації відповідно до принципів, прийнятих у розвинених країнах світу з ринковою економікою, хоча вади колишньої планової системи значною мірою залишалися невикорінними (наприклад, неповороткість системи, повільне впровадження новітніх досягнень 
науки та техніки у виробництво, а також внесення на їх основі змін до нормативно-технічних документів).

Водночас було внесено зміни до Закону України «Про стандартизацію» від 17.05.2001 p. № 2408-111, уточнено мету стандартизації в Україні, до якої додано підтримку розвитку та міжнародної конкурентоспроможності продукції в процесі торгівлі товарами та послугами. 3'явилася і нова норма про прийняття і застосування органами стандартизації на території України Кодексу доброчинної практики 3 розроблення, прийняття та застосування стандартів відповідно до Угоди СОТ про технічні бар'єри в торгівлі. Разом із тим не було скасовано залишки раніше вже відкоригованого Декрету Кабінету Міністрів України «Про стандартизацію і сертифікацію» від 10.05.1993 р. № 46-93, що втратив цінність у сфері стандартизації.

У 2003 р. $з$ прийняттям ГК України (ст. 15) господарське законодавство офіційно збагатилося новими нормами 3 питань стандартизації, про що вже йшлося. Така позиція законодавця надала можливість більш широко застосовувати вимоги стандартизації при здійсненні господарської діяльності.

Водночас, зважаючи на перспективи вступу України до СОТ, до ГК України було внесено такі застереження: 1) у разі виготовлення продукції на експорт, якщо угодою (контрактом) визначено інші вимоги, ніж ті, що встановлено нормативно-правовими актами України, дозволяється застосування положень угоди (контракту), якщо вони не суперечать законодавству України у частині вимог до процесу виготовлення продукції, іiї зберігання та транспортування на території України; 2) з метою запобігання наданню послуг і реалізації продукції, небезпечних для життя, здоров’я та майна громадян і довкілля, сприяння споживачеві у виборі продукції, створення умов для участі суб'єктів господарювання в міжнародному економічному, науково-технічному співробітництві та міжнародній торгівлі здійснюється сертифікація, тобто підтвердження відповідності якості продукції та послуг вимогам стандартів.

Розвиваючи ідеї, закладені у законодавство України, науковці різних напрямів та галузей здійснювали та здійснюють чисельні дослідження, що 
надають можливість проаналізувати відносини у сфері господарської діяльності у багатьох вимірах та під різними кутами зору.

\section{Основні наукові положення щодо стандартизації, що розвивалися у} пострадянській Україні. Наукова думка у сфері стандартизації формувалася на основі радянських наукових праць, що виходили з основної мети стандартизації забезпечення технічної складової народного господарства. Після здобуття Україною незалежності і до цього часу мета стандартизації трансформувалася та розширилася до безпеки не лише товарів (послуг), а й людини, довкілля, суспільства, держави. Водночас власне технічний напрям стандартизації нікуди не зникав та є широким полем для здійснення пошукових робіт. Такими прикладами $є$ наукові праці (в основному - дисертаційні дослідження), що проводилися щодо:

1) технічних характеристик товарів (послуг), об’єктів, їх частин, складових:

- С. С.Гузій у праці «Абсолютна спектрофотометрія стандартних зір проміжної яскравості в діапазоні 3200-7900 ЕЕ» (Автореф. дис... канд. фіз.-мат. наук: 01.03.02. О., 2001. 16 с.) веде мову про визначення даних про абсолютний розподіл енергії у спектрі, що може бути використано для проведення калібрування спектральної апаратури, стандартизації фото- та спектрофотометричних спостережень та для уточнення фундаментальних характеристик зір, моделей атмосфер і вибору спектральних діапазонів для гетерохромної фотометрії. Проте не досліджується безпековий, соціальний та інші аспекти стандартизації, що є класичним прикладом дослідження питань стандартизації в технічних науках;

- Г. В. Літошенко у науковій праці «Стандартизація і оцінка комфортності житла» (Автореф. дис... канд. архіт.: 18.00.01. К., 2004. 20 с.) пропонує новий метод класифікації багатоквартирного житла за рівнем комфортності відповідно до його призначення (соціального, приватного, прибуткового), а також нові принципи розробки нормативних документів і методів оцінки якості у галузі проектування багатоквартирного житла. У цій роботі зміщується кут огляду проблеми, а тому стандартизація та їі вимоги вже розглядається не лише як джерело критеріїв для оцінювання та класифікування, а й для оцінки якості та безпеки; 
2) процесу виробництва чи здійснення окремих видів господарської діяльності:

- В. М. Бутенко пропонує загальну модель функціонування стаціонарних об'єктів залізничної автоматики, що використовуються в нормативному забезпеченні мікропроцесорних систем диспетчерського управління (Стандартизація моделей безпечного управління стаціонарними об’єктами залізничної автоматики. Автореф. дис... канд. техн. наук: 05.01.02. К., 2004. 20 с.). Автор синтезував розширені моделі функціонування вказаних об'єктів на базі мереж Петрі, які використано під час розробки проекту. Тобто йдеться не лише про розробку проблеми управління стаціонарними об'єктами залізничної автоматики, а й про можливість розробки галузевого стандарту з включенням до нього усіх безпекових і соціальних вимог;

- І. О. Храмова дослідила, що необхідною умовою створення корпоративної інформаційної інфраструктури системи підтримки прийняття рішень $є$ структурування та стандартизація понять предметних галузей (Дослідження інформаційних інфраструктур підготовки даних для прийняття рішень. Автореф. дис... канд. техн. наук: 05.13.06. К., 2007. 23 с.). Таким чином до усіх існуючих аспектів стандартизації додають іiі інформаційну спрямованість, що водночас забезпечує структурування семантичних метаданих у моделях даних, процесах (послугах) пошуку знань;

3) визначення критеріїв оцінки та метрології:

- М.В. Дмітрієва, вивчаючи критичні чинники методик випробування на розчинення, у праці «Стандартизація випробувань на розчинення дозованих лікарських форм» (Автореф. дис... канд. фармац. наук: 15.00.03. Х., 2008. 20 с.), аналізує вимоги провідних фармакопей світу та доходить висновку про необхідність і своєчасність гармонізації вимог Державної Фармакопеї України 3 Європейською Фармакопеєю;

- В. В. Нечипорук у науковій праці «Метод підвищення точності систем діагностики технічного обладнання на основі стаціонарної вимірювальної інформації» (Автореф. дис... канд. техн. наук: 05.11.16. К., 2007. 19 с.) пояснює 
залежність між методом масштабних коефіцієнтів та індикаторними функціями стандартизації у сфері інформаційних сигналів (наприклад, виділено основні типові класи випадкових процесів, для яких стандартизація може стати і розв'язком, і методом оцінки технічного завершення);

4) суміжних проблем:

- О. В. Бандирська досліджувала стандартизацію безнадлишкових рядів методом оптимальних структурних пропорцій (Автореф. дис... канд. техн. наук: 05.01.02. Львів, 2000. 20 с.). У іiі праці йдеться про мінімізацію базових мір у впорядкованих наборах мір (мінімізації числа поділок шкал), що надає можливість поліпшувати техніко-економічні показники виробництва та забезпечити якість і конкурентоспроможність продукції. Тобто навіть у технічних науках прослідковується тенденція до переходу в суміжні галузі для пояснення явищ, властивих саме цій галузі знань;

- О.М. Величко при розгляді питання оптимізації основних складових підсистем багаторівневої національної системи стандартизації у галузі метрології встановила взаємозв'язки національної системи стандартизації у галузі метрології з їі глобальним зовнішнім середовищем (Оптимізація багаторівневої системи стандартизації національного рівня в галузі метрології (теорія та практика). Автореф. дис... док. техн. наук: 05.01.02. Л., 2007. 42 с.). Водночас автор не веде мову про уніфікацію та застосування в Україні міжнародно визнаних вимог у сфері метрології, а знову пропонує встановлювати особливості застосування в Україні підсистем одиниць фізичних величин;

- Т. Г. Бойко при аналізі шляхів розвитку кваліметрії в науково-технічній сфері пов’язала ії майбутнє з національною системою технічного регулювання та господарсько-економічною діяльністю. У праці наголошується на необхідності однозначного розуміння та трактування термінологічного апарату, що є умовою виконання вимог щодо забезпечення єдності та точності одержання кількісного оцінювання якості (Формування теоретичних та нормативно-технічних засад оцінювання якісного рівня продукції. Автореф. дис. ... док. техн. наук : 05.01.02. 
Л., 2010. 34 с.). Хоча в роботі йдеться лише про систему технічного регулювання, та вона є прогресивною, бо показує тенденції розвитку технічної науки у сфері стандартизації;

- I. C. Соколовська у праці «Розробка науково-методичних засад удосконалення системи нормативних документів в галузі електроенергетики України» (Автореф. дис. ... канд. техн. наук : 05.01.02. К., 2011. 20 с.) розпочала дискусію про необхідність впровадження комплексної стандартизації, що надає можливість створити універсальну модель такої стандартизації та враховувати технічні, економічні, екологічні та соціальні аспекти функціонування окремої галузі. Автор також запропонувала ієрархічний підхід до побудови масиву нормативних документів стандартизації, які забезпечують надійну й ефективну роботу галузі. Поряд 3 цим не оцінюється регулюючий вплив стандартизації на окремий сектор економіки чи галузі господарства;

- Л. М. Віткін є розробником ідей, що виходять далеко за межі технічної науки. У роботі «Наукові засади створення системи технічного регулювання в умовах членства України в СОТ та інтеграції до ЄС» (Автореф. дис. ... док. техн. наук : 05.01.02. К., 2011. 41 с.) запропоновано поетапне реформування існуючої централізованої системи технічного регулювання у напівінтегровану систему, розроблено методологічні засади та принципи створення сучасної системи технічного регулювання, визначено закономірності особливостей, на підставі яких побудовано модель подолання технічних бар'єрів на шляху просування вітчизняної продукції на світові ринки. Автор наголошує на необхідності укладання угоди про оцінку відповідності та прийнятність промислової продукції між Україною та $\mathrm{CC}$, але не говорить про те, що європейський ринок функціонує на основі системи стандартизації, яка $є$ першоосновою при регулюванні відносин у сфері господарської діяльності.

Паралельно наукові засади стандартизаиії розвивали економісти та управлінці, оскільки саме вони формували та розвивали господарську діяльність підприємств, а також поставили питання конкурентоспроможності товарів і 
послуг. 3 суто економічних інтересів (отримання прибутку) розвивалися також наукові засади підвищення якості товарів та послуг.

Першим напрямом можна вважати стандартизацію підготовки та діяльності персоналу (людського ресурсу):

- Ю.А. Дайновський розробляв методи генерації і модифікації стандартизованих рішень, які сприяють цілеспрямованому пошуку розв'язань у конкретних проблемних ситуаціях. Він сформулював принципи стандартизації управлінських рішень, запропонував створення банків рішень для спрощення роботи персоналу на підприємстві, що стане гарантією підвищення ефективності й оперативності підприємницької діяльності (Методологічні основи формування управлінських рішень у підприємництві. Автореф. дис... док. екон. наук: 08.06.02. Львів, 2000. 31 с.). По суті, це вже йдеться про зародження саморегулівної діяльності суб'єкта господарювання на основі загальних засад стандартизації;

- Ж. В. Таланова у праці «Стандартизація фахової підготовки з державного управління в країнах Північної Америки і Європи» (Автореф. дис... канд. наук 3 держ. упр.: 25.00.03. К., 2004. 20 с.) розглянула питання підготовки фахівців 3 управління, для цього було досліджено практику північноамериканських i західноєвропейських країн та сформульовано зважену позицію про стратегію вдосконалення вітчизняної системи стандартів у галузі освіти за умов глобалізації, євроінтеграції та національної самоідентифікації;

- Н. Г. Синицина досліджувала подібну проблему: концептуальні, теоретико-методологічні та практичні аспекти стандартизації освіти державних службовців в Україні. У роботі «Стандартизація освіти державних службовців в Україні» (Автореф. дис... канд. наук з держ. упр.: 25.00.03. Д., 2006. 20 с.) науково обгрунтовано систему контролю та критерії оцінювання якості освіти. Автор доводить залежність між стандартизацією освіти та підтвердженням відповідності знань, хоча не говорить про таку саму залежність між стандартизацією освіти управлінців та якістю наданих ними послуг при здійсненні посадових обов’язків;

- С. О. Савченко пропонує за рахунок автоматизації та стандартизації 
бізнес-процесів вищого навчального закладу та його підрозділів, організація інформаційних потоків яких відбувається за допомогою даної структурнофункціональної моделі системи управління бізнес-процесами цієї установи (Моделі інноваційного управління вищим навчальним закладом. Автореф. дис. ... док. екон. наук : 08.00.11. Донецьк, 2010. 37 с.). Йдеться про імітаційні моделі оцінювання впливу якості освіти на ринок праці й оплати праці викладачів вищого навчального закладу, системо-динамічну модель управління його науковою діяльністю та економіко-математичну модель фінансового менеджменту. Прослідковується тенденція у розробках вчених, коли стандартизація чи ії вимоги стають визначальними (ключовими) критеріями для оцінювання ефективності чи прибутковості окремого суб'єкта господарювання.

Другим напрямом є стандартизація у сфері ресурсної бази (у тому числі обігу грошей):

- Л. Л. Горецька у процесі характеристики природи сучасного процесу реформування обліку активів в контексті міжнародних вимог проаналізувала основні риси світової інтеграції: гармонізацію, стандартизацію або уніфікацію у контексті господарської інтеграції для уточнення правильності вибору шляху стандартизації або уніфікації обліку (Активи в національних системах бухгалтерського обліку. Автореф. дис... канд. екон. наук: 08.06.04. К., 2003. 18 с.). Тобто економісти чітко виявляють зв'язок між глобалізаційними процесами та необхідністю інтеграції суб’єктів господарювання до світових ринків 3 допомогою систем стандартизації;

- Н. П. Губар в умовах глобалізації міжнародного бізнесу пропонує стратегію корпоративної диверсифікації, що має стати засобом одержання додаткової вигоди від синергії, яка виникає між видами бізнесу або окремим бізнесом і корпоративною материнською структурою (Стратегії формування конкурентних переваг транснаціональних корпорацій в умовах глобалізації світогосподарських зв’язків. Автореф. дис... канд. екон. наук: 08.02.03. К., 2004. 20 с.). Йдеться про те, що спільні підприємства, які передбачають використання 
капіталу, технології та ліцензії партнера, а також придбання іноземними фірмами підприємств різних форм власності, мають грунтуватися на єдиній уніфікованій (власній чи загальновизначеній) системі вимог стандартизації;

- Г. Ю. Коблянська у праці «Облік та аудит експортно-імпортних операцій підприємств» (Автореф. дис... канд. екон. наук. К., 2009. 21 с.) пропонує методику проведення аудиторської перевірки експортно-імпортних операцій підприємств у контексті системного підходу щодо іï формування. Основою цієї методики $є$ стандартизація процедур аудиту експортно-імпортних операцій підприємств та вимог до формування достовірної інформації про види діяльності у фінансовій звітності підприємств.

Третім напрямом є стандартизація регуляторної політики:

- В.Г.Горник, досліджуючи методологічні засади формування в Україні дієвих механізмів державної промислової політики за умов трансформаційної економіки, визначив напрями державної промислової політики у сфері інноваційної діяльності, серед яких системі стандартизації та уніфікації інноваційних розробок на засадах міжнародних CALS-технологій приділено значну увагу (Державна промислова політика в умовах структурної трансформації економіки України. Автореф. дис... канд. наук 3 держ. упр. Х., 2005. 20 с.). Йдеться про узгоджені державою заходи, призначені для здійснення якісних та кількісних структурних, інноваційних, інвестиційних перетворень реального сектору економіки з метою стимулювання економічного зростання, підвищення конкурентоспроможності товарів та послуг на ринках, а також зміцнення національної економічної безпеки;

- С. С. Олейнікова у праці «Державне регулювання систем стандартизації та сертифікації в Україні» (Автореф. дис... канд. наук з держ. упр. Донецьк, 2008. 20 с.) дослідила ці системи як метод державного регулювання та визначила необхідність удосконалення механізмів державного регулювання систем стандартизації та сертифікації. Йдеться про організаційну, інформаційну i комунікативну функції стандартизації, реалізацію яких пропонувалося покласти на інформаційну службу з питань стандартизації та сертифікації; 
- О.В. Шкарупа у науковому дослідженні «Еколого-економічна оцінка стану регіону в контексті екологічно сталого розвитку» (Автореф. дис... канд. екон. наук. Суми, 2008. 21 с.) пропонує здійснювати регулювання розвитку регіону за допомогою екологічного паспорта, що буде грунтуватися на існуючій системі статистичної інформації та надасть можливість визначити інтегральний показник екологічно сталого розвитку регіону. Прогресивним є твердження про необхідність поділу напрямів стандартизації за економічними, екологічними i соціальними процесами. Тобто бачимо повний відхід від суто технічного розуміння стандартизації до його безпекової грані;

- Т. В. Маматова досліджувала покращення якості в органах державного контролю за умов змін підходів до управління та регулювання їх діяльності та формування нової організаційної культури (Теоретико-методологічні засади реалізації функції державного контролю як публічної послуги. Автореф. дис. ... док. наук з держ. упр. Запоріжжя, 2010. 36 с.). Для цього автор запропонувала тезаурусну базу гармонізації національних стандартів у сфері контрольної діяльності з міжнародними та європейськими вимогами. Йдеться про уніфікацію вимог до контролю, але звужуючись лише до технічного регулювання, забуваючи, що існує й позадержавний контроль, що теж потребує уніфікації;

- М. М. Іжа у науковій праці «Система регіонального управління: світовий досвід і Україна» (Автореф. дис. ... док. політ. наук : 23.00.02. К., 2011. 36 с.) вказує на особливості функціонування регіонального рівня управління у зарубіжних державах і Україні з огляду на сучасні тенденції глобалізації, регіоналізації та децентралізації. На підставі аналізу процесів на регіональному рівні у країнах Західної та Східної Європи визначено, що глобалізація не призводить до стандартизації регіонів різних країн, не нівелює їх територіальні та культурні особливості, а створює для них нові можливості для розвитку в економічній, соціальній, культурній сферах. Показано, ще найкращим шляхом розвитку для держави та регіонів є пристосування до мінливих рамок глобалізації. 
споживачів:

- О.В. Мишко у праці «Механізм трансформації та розвитку системи управління якістю товарів та послуг в Україні» (Автореф. дис... канд. екон. наук: 08.00.03. Л., 2008. 20 с.) відзначив доцільність розгляду подальшої адаптації українського законодавства до європейського як передумови розвитку національної системи управління якістю відповідно до вимог СОТ. Серед пріоритетів розвитку стандартизації та сертифікації в Україні названо узгодження великої кількості правово-нормативних документів, що стосуються якості товарів, захисту прав споживачів і охорони навколишнього середовища, оскільки вони не створюють єдиного правового поля;

- В. О. Кислицин називає систему управління якістю базою для створення стратегії конкурентоспроможності підприємства за умов глобальної конкуренції (Система управління якістю як основа стратегії конкурентоспроможності підприємства. Автореф. дис... канд. екон. наук: 08.00.04. Маріуполь, 2007. 20 с.). Водночас цілком справедливо відзначається роль стандартизації як першооснови для впровадження системи управління якістю;

- Ю. В. Ставська у праці «Управління якістю продукції птаховиробничих підприємств в умовах глобалізації» (Автореф. дис... канд. екон. наук : 08.00.04. К., 2011. 21 с.) та В. А. Рафальська у праці «Управління якістю цукру в умовах глобалізації світової економіки» (Автореф. дис... канд. екон. наук: 08.07.02. К., 2006. 21 с.) ведуть мову про необхідність запровадження не фрагментарної, а комплексної стандартизації, а також наголошують на важливості держави в управлінні стандартизацією та сертифікацією відповідно до міжнародних вимог, а також при регулюванні та мотивації виробництва якісної продукції;

Одним із аспектів, що мав забезпечити економічну складову господарської діяльності та дисциплінувати суб'єктів такої діяльності, стала юридична відповідальність. Науковці почали вести мову про адміністративну, кримінальну та договірну відповідальність суб’єктів господарської діяльності у сфері невиконання вимог стандартизації. 3 подальшим розвитком юридичної наукової 
думки постало питання про впровадження попереджувальних, роз'яснювальних та інших запобіжних заходів у сфері стандартизації, що дозволяло б суб’єкту господарської діяльності мати певну свободу дій, але з можливістю застосування санкцій у разі порушення юридичних норм. Разом 3 тим юристи активно досліджують проблеми організаційно-правових засад стандартизації чи ії окремих складових:

С. Ф. Демченко у праці «Організаційно-правове забезпечення раціонального використання матеріальних ресурсів в Україні» (Автореф. дис... канд. юрид. наук: 12.00.07). К., 1999. 20 с.) досліджував теоретичні правові і прикладні проблеми вдосконалення правового регулювання управління, стандартизації і контролю у сфері забезпечення раціонального використання i економічного витрачання матеріальних ресурсів в Україні. Йдеться про необхідність державного регулювання раціонального використання матеріальнотехнічних ресурсів для забезпечення функціонування ринкових відносин, залучення іноземного капіталу, впровадження передової техніки та технологій. Стандартизації приділяється незначна увага, а результати спрямовані на вдосконалення діяльності органів управління в сфері забезпечення раціонального використання матеріальних ресурсів;

- А. М. Мірошниченко у науковому дослідженні «Нормування як засіб правового регулювання земельних відносин» (Автореф. дис... канд. юрид. наук: 12.00.06. К., 2004. 19 с.) веде мову про нормування, зокрема земельно-правове, i визначає його як засіб правового регулювання, спрямований на забезпечення раціонального використання, охорони та відтворення земель. Одночасно автор говорить про необхідність прояву нормування у вигляді стандартизації, що, як ми вважаємо, є помилковим, оскільки може йтися лише про закріплення нормування у вигляді вимог стандартизації у нормативно-технічних документах;

- А. С. Ластовецький розглядав питання удосконалення засобів організаційно-правового впливу держави на розвиток підприємництва та запропонував ще тоді вдосконалювати сертифікацію та стандартизацію продукції, 
що надасть можливість розвиватися малому та середньому бізнесу в Україні (Організаційно-правові засади регулювання підприємницької діяльності в Україні. Автореф. дис... канд. юрид. наук: 12.00.07. Ірпінь, 2005. 20 с.). Тоді ще не йшлося про членство у СС, але вимоги СОТ щодо виходу українського бізнесу на світові ринки активно обговорювалися;

- Е. М. Деркач, досліджуючи доволі вузьку проблему у праці «Правове регулювання перевезення вантажів залізничним транспортом» (Автореф. дис... канд. юрид. наук: 12.00.04. Донецьк, 2007. 20 с.), також наголошує на необхідності державного регулювання залізничного перевезення вантажів, зокрема, регулювання цін і тарифів, ліцензування, сертифікації та стандартизації. Одночасно у загальних рисах йдеться про розмежування сфер державного регулювання перевезення вантажів залізничним транспортом та, власне, «вільної» господарської діяльності у цій сфері;

- В.В. Добровольська у науковому дослідженні «Правові засади державного регулювання підприємницької діяльності в Україні» (Автореф. дис... канд. юрид. наук: 12.00.04. Донецьк, 2007. 17 с.) запропонувала прогресивні тези щодо місця та ролі держави у регулюванні підприємництва, зробивши акцент на забезпеченні саморегулювання цієї сфери. Окремо було досліджено конкретні засоби державного регулювання підприємництва, у тому числі стандартизацію. Водночас не було охарактеризовано стандартизацію як засіб саморегулювання у підприємництві;

- М. О. Богославська, досліджуючи окремі проблеми у сфері криміналістики, звертає увагу на необхідність формування понятійного апарату (експертної мови та термінологічних систем) з допомогою стандартизації (Судова лінгвістична експертиза: процесуальні і криміналістичні аспекти: автореф. дис... канд. юрид. наук: 12.00.09. К., 2009. 19 с.). Стандартизація у даному випадку розглядається на технократичних засадах суто уніфікації та типізації, хоча неопосередковано йдеться також про оцінку відповідності та методичні засади іiі здійснення; 
- О. М. Дорошева, досліджуючи імпорт лікарських засобів як специфічний вид господарської діяльності, говорить про особливості господарсько-правового регулювання цього виду зовнішньоекономічної діяльності, що засновується на договорах, але регулюється не лише державою Україна, а й міжнародними організаціями (Правове регулювання імпорту лікарських засобів. Автореф. дис... канд. юрид. наук: 12.00.04. Донецьк, 2009. 18 с.). Зокрема, у контексті адаптації законодавства України до права СС автор пропонує оновити вимоги сертифікації та стандартизації для усунення технічних бар'єрів у торгівлі;

- Я. М. Шатковський (Стандартизація у системі обов’язкового медичного страхування в Україні (адміністративно-правовий аспект). Автореф. дис... канд. юрид. наук: 12.00.07. К., 2009. 20 с.) та В. Ю. Стеценко (Адміністративно-правове забезпечення запровадження в Україні обов'язкового медичного страхування. Автореф. дис. ... д-ра юрид. наук : 12.00.07. Х., 2010. 40 с.) досліджували питання запровадження обов'язкового медичного страхування в Україні. Вони визначили, що медичні стандарти є складовою частиною системи стандартизації, яка функціонує в Україні, та розробляються компетентним органом. Такими, по суті, є прийняті чи затверджені у встановленому законодавством порядку правила надання медичних послуг, організації та управління охороною здоров’я, реалізація допоміжних заходів, спрямованих на забезпечення медичної допомоги, метою яких є забезпечення прав, свобод i законних інтересів пацієнтів та об'єктивізація лікувально-діагностичного процесу. Обов'язковою складовою цієї системи автори називають якість, а також методики ï оцінювання. Водночас прогресивні ідеї нівелюються твердженням про вимоги до медичних стандартів, що $є$ не власне вимогами, а принципами стандартизації.

Після прийняття Закону України «Про технічні регламенти та процедури оцінки відповідності» у 2005 р. та змін до нього у вигляді нового Закону України «Про технічні регламенти та оцінку відповідності» у 2015 році науковці часто звертаються до питань правового регулювання (забезпечення) технічних регламентів та/чи технічного регулювання окремих видів господарської діяльності: 
- В. О. Сергійчик порушує питання технічного регулювання у галузі торговельного мореплавства (Адміністративно-правові засади виконання Україною обов'язків держави прапора щодо контролю технічного стану морських суден. Автореф. дис. ... канд. юрид. наук : 12.00.07. О., 2010. 19 с.). Йдеться про забезпечення виконання Україною обов'язків держави прапора щодо контролю технічного стану морських торговельних суден шляхом вдосконалення адміністративно-правових засад виконавчо-розпорядчої діяльності відповідних органів виконавчої влади. Центральною тезою є необхідність змінити склад центральних органів виконавчої влади України щодо технічного регулювання у галузі торговельного мореплавства та визначити їх функціональну компетенцію. Про вимоги, контроль яких має здійснювати Україна як держава прапора, майже не йдеться;

\section{- С. М. Орєхов (Адміністративно-правове регулювання в галузі} стандартизації, якості продукції, метрології і сертифікації: автореф. дис. ... канд. юрид. наук : 12.00.07. К., 2011. 20 с.) та В. Ю. Волков (Адміністративно-правове регулювання в галузі стандартизації та сертифікації в Україні: автореф. дис. ... канд. юрид. наук : 12.00.07. О., 2013. 20 с.) досліджували питання стандартизації 3 позицій адміністративно-правового регулювання. Вони визначали ії як об’єкт державного регулювання у контексті адаптації чинного законодавства України до вимог $\mathrm{CC}$, хоча розглядали також питання обов'язковості та добровільності вимог у сфері стандартизації, процедури створення таких вимог, у тому числі технічних регламентів. Технічні регламенти названо найвищим ранговим документом серед нормативно-технічних документів стандартизації;

- I. C. Терлецька, розглядаючи питання демократизації та відкритості законопроектної процедури та наукового забезпечення робіт кожної законопроектної стадії, доходить висновку про необхідність уніфікації та стандартизації навіть правил законодавчої техніки (С. Законопроектування в Україні: теоретико-правові аспекти. Автореф. дис. ... канд. юрид. наук : 12.00.01. К., 2011. 20 с.). Одночасно автор говорить про підвищення правової культури 
законопроектувальників, що надасть можливість покращити нормативно-правове регулювання усіх видів діяльності в Україні відповідно до викликів часу;

- Р. М. Бірюков у праці «Національна правова система в умовах глобалізації (основні напрямки трансформації)» (Автореф. дис. ... канд. юрид. наук : 12.00.01. O., 2011. 20 с.) розглядав стандартизацію як метод (прийом) універсалізації національного права в умовах подальшого посилення впливу міжнародного права на національне право, зміцнення позиції регіонального права при функціонуванні національної правової системи і впливу наднаціонального права як продукту глобалізаційних процесів на національну правову систему. Одночасно йдеться про необхідність збереження самобутності національної правової системи за умов глобалізації, але не зазначено, яку роль при цьому відіграє стандартизація;

- Ю. Т. Добромислов у науковій праці «Адміністративно-правове регулювання у сфері захисту прав споживачів» (Автореф. дис. ... канд. юрид. наук : 12.00.07. К., 2011. 19 с.) відносить до засобів механізму захисту прав споживачів ліцензування підприємницької діяльності та технічне регулювання, але не говорить про стандартизацію як основу такого механізму;

- Т. В. Каплюченко, розглядаючи правове регулювання захисту здоров'я та безпеки споживачів і споживчого ринку продовольчих і непродовольчих товарів, проаналізувала поняття «технічне регулювання» $з$ української правової доктрини, що відсутнє у правовій доктрині СС як окрема сфера правового регулювання та кореспондується 3 правовим регулюванням якості товарів $\mathrm{i}$ послуг (Правове регулювання ринкового нагляду на внутрішньому споживчому ринку непродовольчих товарів СС. Автореф. дис. ... канд. юрид. наук: 12.00.11. К., 2016. 20 с.). У дослідженні аналізується також правове регулювання стандартизації в ЄС, що здійснюється на основі Регламенту ЄС № 1025/2012, який має загальне значення для законодавства про безпеку продукції i продовольчого законодавства.

Найбільш значущими та знаковими $є$ наукові дослідження Д. І. Сакояна (Правове регулювання стандартизації в промисловості. Автореф. дис. ... канд. 
юрид. наук: 12.00.04. К., 2011. 20 с.) та І. А. Гамбург (Правове забезпечення технічного регулювання у сфері господарювання. Автореф. дис. ... канд. юрид. наук: 12.00.04. К., 2014. 24 с.):

- Д. І. Сакоян розглядає національну стандартизацію як складову частину державної економічної політики, що діє завдяки взаємодії технічних та юридичних засобів та має на меті впровадження передових технологій. Позитивним є сприйняття стандартизації (у законодавчому полі) не як складової частини технічного регулювання, а у вигляді унікальної сфери суспільної діяльності. Водночас автор веде мову лише про окрему сферу господарської діяльності - промисловість, не торкаючись питань застосування (впровадження) стандартизації в усіх сферах господарської діяльності та ï можливостей для врегулювання широкого кола господарських правовідносин;

- I. А. Гамбург визначає стандартизацію лише як один із засобів технічного регулювання. Одночасно автор зазначає, що технічне регулювання включає лише частину стандартизації (обов’язкову стандартизацію), оцінку відповідності, що є формою доказування. Така позиція засновується на законодавстві України, оскільки на цьому рівні регулювання вже виокремлено сфери стандартизації, технічного регулювання та оцінки відповідності, тобто, відповідно до цих положень, стандартизація не охоплюється технічним регулюванням.

У цілому можна дійти висновку, що наукова думка про стандартизацію, iii зміст та перспективи розвитку пройшла довгий шлях та має свій прояв у технічних, економічних та правових галузях. Технічні наукові розробки були першоосновою, спочатку йшлося про суто уніфікаційні та класифікаційні властивості (завдання) стандартизації, але надалі відбувся перетин цих досліджень 3 економічними та правовими проблемами. Вчені-економісти, зазвичай, говорили про стандартизацію як засіб регулювання економіки, як упорядковуючий (уніфікуючий) фактор в процесах управління, але в умовах адаптації ринку України до глобальних ринків йдеться також про застосування стандартизації як засобу регулювання господарської діяльності (ії окремих видів) 
та про вдосконалення правової бази підприємництва 3 допомогою стандартизації для підвищення відповідності суб'єктів господарювання світовим вимогам. Юридична сфера традиційно була представлена науковими працями, спрямованими на правове регулювання процесів управління стандартизацією та суміжними видами діяльності. Доволі часто юристи акцентують увагу на правових засадах управління, особливостях застосування стандартизації як діяльності в окремих галузях господарської чи управлінської сфери, а також ставлять питання особливостей та процедур застосування різних видів відповідальності у сфері стандартизації. Деякі вчені досліджували сутність, зміст та значення окремих нормативно-технічних документів стандартизації, а також нову сферу - технічне регулювання. Водночас комплексного дослідження сутності, значення та правового забезпечення стандартизації для потреб ринку як національного, регіонального, так і глобального рівня не проводилося до цього часу.

На основі викладеного вище постає питання з визначення методологічного підходу до дослідження проблем стандартизації у механізмі правового регулювання господарської діяльності. У філософських (наукознавчих) вченнях формою усвідомлення науки називають методологічний аналіз, що з'ясовує способи поєднання знання і діяльності, будову, організацію, способи одержання та обгрунтування знань $[153$, с. $23 ; 183$, с. $4-5 ; 279$, с. 13-14]. Виявляючи умови і передумови пізнавальної діяльності, у тому числі філософсько-світоглядні, методологічний аналіз перетворює їх в засоби усвідомленого вибору та наукового пошуку. Такими засобами $\epsilon$ логічні методи, що $\epsilon$ фундаментальними загальнонауковими способами отримання нового знання (не лише наукового, оскільки ці методи використовуються повсякденно).

Керуючись філософським принципом всезагального взаємозв'язку, пропонуємо розгорнуте наукове дослідження, позбавлене однобічності у вивченні об'єкта, з урахуванням усіх суттєвих (значущих) аспектів та зв'язків стосовно господарської діяльності, що розглядається через призму стандартизації, іiі 
значення для цієї діяльності та впливу на правовідносини, що породжує така діяльність. Використання цього принципу надає можливість уникнути в процесі аналізу та наданні висновків таких крайнощів, як софістика, що грунтується на висвітлюванні окремих властивостей предмета дослідження, та еклектика, що грунтується на об’єднанні багатьох різнорідних, внутрішньо не пов'язаних між собою характеристик предмета. Саме тому основним предметом дослідження у цій праці $є$ господарська діяльність та забезпечення іiі впорядкування за допомогою стандартизації, а також питання удосконалення предмета дослідження шляхом задоволення потреб суб’єктів господарської діяльності, що виникають при глобалізаційних процесах.

Нижче буде представлено три основоположні блоки дослідження, що задовольняють принцип всезагального взаємозв'язку: 1) стандартизація (поняття, зміст та акти регулювання); 2) регулювання господарської діяльності за допомогою стандартизації (зміст, регулятивні та охоронні господарські відносини, що виникають у процесі господарської діяльності, а також суб'єкти господарської діяльності як суб’єкти стандартизації); 3) вдосконалення регулювання господарської діяльності на основі міжнародних та регіональних вимог стандартизації.

\section{Висновки до розділу 1}

Накопичений науковий досвід $\mathrm{i}$ високий рівень розвитку теорії стандартизації в СРСР у подальшому став основою для успішного розвитку теорії та методології національної стандартизації та надає змогу брати активну участь у розробленні міжнародних стандартів 3 метою ефективного регулювання господарської діяльності в Україні. 
Перехід від «радянської» стандартизації до сучасного розуміння відбувався в три етапи: на першому (з 1993 р.) відбувалося створення національної системи стандартизації з використанням «радянської» термінології та усього масиву нормативно-технічних документів СРCP; на другому (3 2001 p.) удосконалювалося розуміння сутності стандартизації та їі мети, внаслідок чого виникла безпекова складова (захист споживачів, довкілля та насичення ринку безпечними та якісними товарами і послугами); третій етап (3 2015 р.) знаменується переходом до стандартизації, що відповідає вимогам світового ринку та міжнародним вимогам якості та безпеки товарів і послуг.

Засадничі основи стандартизації ще у середині XX ст. сформувала ISO. Відштовхуючись від керівних принципів та засад формування стандартизації в ISO, кожна країна формує власний пакет вимог, відкриваючи чи захищаючи таким чином власний ринок товарів (послуг). Історично склалося так, що стандарти ISO приймають (адаптують) не лише окремі, а й об'єднані (колективні) суб'єкти міжнародного права, надалі впроваджуючи їх у національні системи стандартизації. Україна сьогодні є членом СОТ та перебуває на шляху до вступу в $€ C$, а тому ми маємо зосередитися на принципових засадах функціонування стандартизації в європейських країнах, вдосконалити власне правове забезпечення стандартизації для усунення технічних бар'єрів у торгівлі та допомогти забезпечити суб'єктів господарської діяльності інформацією про умови роботи на ринках цих країн.

На сучасному етапі правові основи стандартизації в Україні визначають закони України «Про стандартизацію», «Про технічні регламенти та оцінку відповідності», «Про державний ринковий нагляд i контроль нехарчової продукції» та інші. Політика в сфері технічного регулювання віддзеркалена також у правових нормах щодо якості продукції, які містяться в нормативних актах 3 широкого кола питань (ГК України, законах України: «Про охорону навколишнього природного середовища», «Про захист прав споживачів», «Про забезпечення санітарного та епідемічного благополуччя населення», «Про основні 
принципи та вимоги до безпечності та якості харчових продуктів», «Про державну систему біобезпеки при створенні, випробуванні, транспортуванні та використанні генетично модифікованих організмів», «Про загальну безпечність нехарчової продукції» тощо). Закони запровадили новації, які наближують національну систему стандартизації до міжнародної. Найважливіші 3 них: запровадження принципу добровільності, нової категорії нормативних документів (технічного регламенту); встановлення та застосування знака відповідності національним стандартам як добровільної процедури; можливість вибору процедури оцінки відповідності. Таким чином, стандартизація стала основоположною для технічного регулювання.

Наукова думка про стандартизацію, іiі зміст та перспективи розвитку пройшла довгий шлях та має свій прояв у технічних, економічних та правових галузях. Деякі вчені досліджували сутність, зміст та значення окремих нормативно-технічних документів стандартизації, а також нову сферу - технічне регулювання. Водночас комплексного дослідження сутності, значення та правового забезпечення стандартизації для потреб ринку як національного, регіонального, так і глобального рівня не проводилося до цього часу.

Комплексність проблеми стандартизації у механізмі правового регулювання господарської діяльності спричинила необхідність обрати філософський принцип всезагального взаємозв'язку та здійснити розгорнуте наукове дослідження, позбавлене однобічності у вивченні об'єкта, з урахуванням усіх суттєвих (значущих) аспектів та зв'язків. 


\section{РОЗДІЛ 2}

\section{СТАНДАРТИЗАЦЯ: ПОНЯТТЯ, ЗМІСТ ТА АКТИ РЕГУЛЮВАННЯ}

\section{1 Поняття та зміст стандартизації}

Стандартизація відіграє суттєву роль при управлінні економікою для підвищення ефективності та продуктивності суспільного виробництва i поліпшення якості продукції [82, с. 4; 97, с. 173]. Вона акумулює найновіші досягнення науки і техніки, органічно поєднує фундаментальні та прикладні галузі науки, сприяє швидкому впровадженню наукових досягнень у практику, допомагає визначити найбільш економні та перспективні напрями розвитку науково-технічного прогресу і різних галузей економіки країни $[7$, с. 8 ; 18 , с. 3 ; 66 , с. $81 ; 141$, с. $67 ; 149$, с. $14 ; 193$, с. 43$] .3$ технічного погляду стандартизація сприймалася та сприймається як складний процес, до складу якого входять такі елементи, як типізація й уніфікація. Під типізацією розуміють втілення типових ознак у якомусь індивідуалізованому предметі, що входить до тієї або іншої видової чи родової групи [234, с. 117]. Уніфікацію сприймають як зведення до єдиної форми, системи, критеріїв чи нормативів [234, с. 451]. 3 іншого боку, типізація й уніфікація - це методи стандартизації, які можуть здійснюватися як самостійні види роботи та є передумовами стандартизації.

Вважаємо, що сьогодні розуміння стандартизації як процесу дуже звужує ii сутність, а тому не може відображати сутність ії регулюючого впливу. Ще у 6070-ті pp. XX ст. виникла наукова думка про те, що сутність стандартизації полягає у встановленні правил, загальних принципів і характеристик для загального та багаторазового застосування з метою захисту життя, здоров'я і майна людини, охорони довкілля й усунення загрози для національної безпеки [55, с. 98, 105; 80, c. 207,$224 ; 277$, c. 56$]$. 
Свого часу в ГОСТ 1.0-68 (нині не діє) стандартизація визначалася як процес встановлення та застосування правил з метою упорядкування діяльності в певній сфері на користь і за участі усіх заінтересованих осіб для досягнення всезагальної оптимальної економії 3 дотриманням умов експлуатації (використання) та вимог безпеки [42, с. 5]. Тобто вже прослідковується відхід від традиційного розуміння стандартизації лише як засобу уніфікації та типізації, а йдеться про створення та реалізацію елементів безпекової складової (поки у вигляді суто технічної).

Правила та вимоги містилися у стандарті, під яким розуміли зразок, еталон, модель, прийняті за вихідні для зіставлення з ними інших подібних об'єктів [42, с. 4-5]. Стандарт як нормативно-технічний документ встановлював комплекс норм, правил, вимог до об’єкта стандартизації і затверджувався компетентним органом. У 1952 p. ISO було створено STACO, який здійснює розроблення та перегляд визначення найважливіших термінів у галузі стандартизації. Починаючи з 1962 р., коли ISO прийняла перше визначення терміна «стандартизація», періодично відбувалось його уточнення, що відображало розвиток стандартизації, зумовлений рівнем розвитку науково-технічного прогресу. Сучасний термін у тлумаченні ISO має таке визначення: «стандартизація - це діяльність 3 метою досягнення оптимального ступеня упорядкування в певній галузі шляхом встановлення положень для загального і багаторазового використання реально існуючих чи можливих завдань» [154]. Ця діяльність складається з процесів розробки, випуску та реалізації стандартів. Важливими перевагами стандартизації ISO/IEC Guide 2:2004 (Стандартизація та суміжні види діяльності - загальний словник) називає поліпшення придатності продукції, процесів і послуг за їх прямим призначенням, запобігання бар'єрів в торгівлі та сприяння технічному співробітництву [288, с. 4]. Це той орієнтир, червона нитка, що пронизує усі подальші розробки не лише в ISO, а й у документах організацій, що прямо не займаються стандартизацією, але використовують іiі досягнення (ГАТТ, СОТ як іiі правонаступниці, ЄС та інших наднаціональних організацій). 
Про безпекову мету стандартизації в офіційних міжнародних і національних документах прямо не йдеться, але коли розробляється окремий вид документа, то в ньому обов'язково зазначається необхідність врахування безпекових факторів, оскільки кожен продукт впливає на навколишнє середовище на всіх етапах його життєвого циклу, від вилучення ресурсів до обробки впродовж життя та необхідності зниження потенційного негативного впливу на навколишнє середовище продукту. Це визнається в усьому світі, а тому практичним інструментом для вирішення цих питань, а також засобом регулювання стійкої міжнародної торгівлі є посібник ISO Guide 64:2008 «Керівництво 3 вирішення екологічних проблем у товарних (виробничих) стандартах».

Нині до бізнес-суб'єкта на світовому ринку неформально пред’являють такі блоки вимог: 1) якість продукції та управління (серія стандартів ISO 9000, ISO 22000); 2) безпека, у тому числі охорона довкілля та інформаційна безпека (серія стандартів ISO 14000, ISO 27000); 3) соціальна відповідальність (серія стандартів ISO 22000, стандарт ISO 26000); 4) чистота бізнесу, у тому числі від ризиків хабарництва (стандарт ISO 37001).

Правове забезпечення якості товарів і послуг (у тому числі послуг навчальних закладів) є предметом дослідження науки господарського права [52, c. 23]. Забезпечити якість можливо через посилення вимог до стандартизації у роботі суб'єктів господарювання. I якраз нині різко зростає роль стандартизації як першооснови для сфери технічного регулювання - від наукових розробок до експлуатації та утилізації виробів. Стандартизація поєднує науку, техніку та виробництво, сприяє забезпеченню єдиної технічної політики в різних галузях економіки, технічному переозброєнню виробництва, широкому впровадженню сучасної техніки і процесів, механізації й автоматизації виробничих процесів, підвищенню якості товарів [80, с. 194; 81, с. 57; 82, с. 6 ; 114, с. 9; 243, с. 13]. Усе це створює умови для розвитку економіки країни. Характерною особливістю стандартизації $\epsilon$ те, що сфера ii дії та застосування, рівень розвитку мають широкий діапазон. Немає такої сфери діяльності людини, до якої б не була 
причетна стандартизація [55, с. 100-101; 239, с. 173-174]. Адже 3 поширенням i поглибленням пізнання, розвитком науки та техніки, удосконаленням виробництва масштаби робіт значно зростають i поширюється сфера використання принципів стандартизації.

Метою стандартизації $\epsilon$ встановлення положень, що забезпечують відповідність об’єктів стандартизації своєму призначенню та їх безпечність для життя, здоров'я, майна людей, збереження тварин, рослин і охорони природного довкілля, що створюють умови для раціонального використання всіх видів національних ресурсів, сприяють усуненню технічних бар'єрів у торгівлі та підвищенню конкурентоспроможності продукції до рівня розвитку науки, техніки i технологій та розвитку міжнародного економічного, наукового і технічного співробітництва. Досягнення цієї мети здійснюється шляхом розроблення, впровадження та застосування нормативно-технічних документів.

Стандартизація відповідно до мети має різні завдання. Вчені-юристи та фахівці суміжних галузей неоднаково формують основні завдання. Узагальнивши та обравши найнеобхідніші, на нашу думку, можна окреслити такі:

- створення нормативної документації, яка встановлює оптимальні вимоги до продукції, що виготовляється для потреб економіки, населення, оборони держави та експорту [150, с. 48];

- безпечність продукції, процесів і послуг для життя, здоров'я та майна людей, збереження тварин і рослин та охорону природного довкілля [147, с. 93];

- якість продукції, процесів і послуг відповідно до рівня розвитку науки техніки, технологій та потреб людей [147, с. 92];

- упровадження новітніх технологій, оновлення виробництва та підвищення його продуктивності $[147$, с. $93 ; 265$, с. 10$]$.

Аналіз положень 3 нормативно-правових актів України у сфері стандартизації надає можливість додати ще: реалізацію прав споживачів; відповідність об'єктів стандартизації своєму призначенню; технічну й інформаційну сумісність і взаємозамінність; збіжність та відтворюваність 
результатів контролювання і випробувань; безпеку господарських об'єктів, складних технічних систем, враховуючи допустимий ризик виникнення природних та техногенних катастроф і інших надзвичайних ситуацій; розвиток міжнародного та регіонального співробітництва; усунення технічних бар'єрів у торгівлі.

Розглядаючи завдання EN, що прописані у Постанові № 1025/2012 Європейського парламенту і Ради СС від 25.10.2012 (Regulation EU № 1025/2012) [293], знаходимо ті самі напрями. Так, європейська стандартизація сприяє:

1) підвищенню конкурентоспроможності підприємств шляхом полегшення, зокрема, вільного переміщення товарів і послуг, взаємодії в мережах, засобів зв'язку, технологічного розвитку та інновацій;

2) глобальній конкурентоспроможності європейської промисловості, особливо коли вона встановлюється у взаємодії 3 міжнародними органами стандартизації (ISO, MEK і MCE);

3) економічному взаємопроникненню на внутрішньому ринку, стимулюючи розвиток нових i покращених продуктів або ринків та поліпшення умов постачання.

Тобто стандартизація, як правило, збільшує конкуренцію та знижує витрати на виробництво та продаж. Стандартизація може підтримувати та підвищувати якість, надавати інформацію та забезпечувати сумісність, тим самим гарантувати безпеку та цінність для споживачів.

Одним із завдань європейської стандартизації $\epsilon$ поширення вимог i стандартів на інші країни, що не входять до CEN, але співпрацюють з CEN та CENELEC, а стандарти цих організацій адаптуються або гармонізуються як національні стандарти. Це сприяє торгівлі між цими країнами та європейським ринком. Зворотним ефектом завдання 3 поширення стандартизації $\epsilon$ ідентичність третини EN міжнародним стандартам ISO. Це так само полегшує міжнародну торгівлю та допомагає європейським компаніям вести справи 3 контрагентами у всьому світі. Стандартизація підтримує економічну діяльність, підвищує 
продуктивність, збільшує торгівлю в рамках єдиного європейського ринку та надає можливість підприємствам різних кластерів, форм та величини отримати доступ до ринків у всьому світі.

Викладене вище надає можливість дійти висновку, що у світі взагалі та Європі, зокрема, ще у середині XX ст. усвідомлювали чіткий взаємозв'язок між використанням стандартів, економічним зростанням, продуктивністю праці та здатністю компаній експортувати свою продукцію на інші (глобалізовані) ринки.

Аналізуючи мету стандартизації в Україні, доходимо висновку, що вона $\epsilon$ організаційно-технічною основою усіх видів діяльності як на національному, так і на міжнародному рівнях. Зміцнення науково-технічних та економічних зв'язків привертає увагу до стандартизації усіх розвинених країн світу та країн, що розвиваються, а також технічних, економічних, міжнародних, регіональних i національних організацій, фірм і підприємств. Це є наслідком об'єктивної необхідності стандартизації та технічного регулювання в управлінні економічними і виробничими процесами.

Законодавчо в Україні стандартизація визначається як діяльність, що полягає у встановленні положень для загального і багаторазового застосування щодо наявних чи можливих завдань 3 метою досягнення оптимального ступеня впорядкування у певній сфері (ч. 1 ст. 1 Закону України «Про стандартизацію» від 15.01.2015 p. № 124-VIII). На сьогодні 3 легального визначення виключили останню частину про те, що результатом стандартизації є підвищення ступеня відповідності продукції, процесів і послуг їх функціональному призначенню, усуненню бар'єрів у торгівлі та сприянню науково-технічному співробітництву. Це, на нашу думку, не доцільно, бо свідчить про нехтування метою цієї діяльності.

Таким є визначення стандартизації як діяльності. Разом із тим в Україні інколи застосовується підхід до розуміння стандартизації як процесу із забезпечення якості, коли законодавство про стандартизацію створює правову базу для визначення якості товарів, послуг тощо [55, с. 102]. Останнім часом 
однією з ключових проблем науково-технічного та економічного розвитку країн $€$ якість продукції. Поліпшення якості продукції (виробів, процесів, робіт, послуг) це проблема не тільки споживча чи технічна, а й економічна, соціальна та політична [99, с. 41; 241, с. 398-399]. На нашу думку, лише після появи законодавства про стандартизацію можна говорити про появу законодавства про якість. Стандартизація завжди існувала завдяки господарській діяльності, але i сьогодні предмет правовідносин, які, по суті, регулює стандартизація, зазвичай називають продовольчою безпекою, безпекою харчування, якістю продукції [32, с. 90-91; 210, с. 234]. Стандартизація є одним із інструментів управління господарською діяльністю. Так у ГК України вона знаходить своє місце серед основних засобів регулюючого впливу держави на діяльність суб'єктів господарювання $[19$, с. $3 ; 82$, с. $5 ; 117$, с. $24 ; 122$, с. $18 ; 146$, с. $293 ; 239$, с. 173]. Деякі вчені вважають, що стандартизація й інші засоби регулюючого впливу держави зможуть урівноважити публічні та приватні інтереси, що надасть можливість суб'єктам господарювання зосередитися на підвищенні економічних показників [264, с. 180]. У науковій літературі пропонується класифікація засобів регулюючого впливу держави на діяльність суб'єктів господарювання, згідно із якою стандартизацію поряд із деякими іншими засобами віднесено до засобів адміністративного характеру, що встановлюють умови та обмеження на здійснення господарської діяльності [50, с. 10; 46, с. 157].

На нашу думку, сучасне розуміння стандартизації має бути ширшим i звучати так: «стандартизаџія - діяльність, що полягає в установленні та застосуванні положень для загального та неодноразового використання щодо наявних чи потенційних завдань і спрямована на досягнення оптимального ступеня впорядкованості в певній сфері суспільного життя для забезпечення своєї мети».

Вважаємо, що у сучасному розумінні стандартизації йдеться про дві складові: технічну та безпекову. Технічна складова є класичною, такою що історично складалася, і визначає технічні вимоги. Безпекова - виникла у середині $\mathrm{XX}$ ст. коли суспільство усвідомило, що підвищення рівня життя, яке є основною 
ознакою науково-технічного прогресу, не повинно вступати в протиріччя із суспільною необхідністю у збереженні довкілля та зміцненні здоров'я людини як основного показника у визначенні рівня розвитку суспільства.

Для оптимального досягнення мети стандартизація має засновуватися на принципах, визначених законодавством (ч. 2 ст. 4 Закону України «Про стандартизацію»): 1) забезпечення участі фізичних та юридичних осіб у розробленні національних стандартів і кодексів усталеної практики; 2) відкритості та прозорості процедур розроблення та прийняття національних стандартів і кодексів усталеної практики 3 урахуванням інтересів усіх сторін; 3) неупередженого прийняття національних стандартів і кодексів усталеної практики на засадах консенсусу; 4) добровільного застосування національних стандартів та кодексів усталеної практики, якщо інше не передбачено нормативно-правовими актами; 5) відповідності національних стандартів і кодексів усталеної практики законодавству; 6) адаптації до сучасних досягнень науки i техніки, сприяння впровадженню інновацій та підвищення конкурентоспроможності продукції вітчизняних виробників; 7) доступності національних стандартів і кодексів усталеної практики, а також інформації про них для користувачів; 8) пріоритетності прийняття в Україні міжнародних і регіональних стандартів та кодексів усталеної практики як національних; 9) дотриманні міжнародних та регіональних правил і процедур стандартизації; 10) участі в міжнародній та регіональній стандартизації; 11) прийнятті та дотриманні суб'єктами стандартизації кодексу доброчинної практики 3 розроблення, прийняття та застосування стандартів відповідно до Угоди СОТ про технічні бар’єри у торгівлі, що є додатком до Марракеської Угоди про заснування СОТ від 15.04.1994 року [241]. Визначення вказаного переліку цілей стандартизації у законодавстві України є позитивним та достатнім. Єдиним суттєвим недоліком є невиконання та незастосування цих принципів на практиці. Наприклад, введення у законодавство України терміна «технічне регулювання»не відповідає дев’ятому принципу (дотримання міжнародних та регіональних правил 
і процедур стандартизаціі), що спричиняє неточне та незрозуміле для іноземних партнерів розуміння цього словосполученням, тим більше, що його прямий переклад також унеможливлюється.

На принципах, визнаних СОТ в галузі стандартизації, базується також діяльність європейських організацій зі стандартизації, CEN, CENELEC та ETSI [293]. Такими є основоположні принципи: узгодженість, прозорість, відкритість, консенсус, добровільне застосування, незалежність від особливих інтересів та ефективність. Відповідно до принципів заснування СОТ важливим є те, щоб всі відповідні зацікавлені сторони, включаючи державні органи та малі і середні підприємства, були належним чином задіяні в процесі національної та європейської стандартизації. Національні органи стандартизації, у свою чергу, мають заохочувати та сприяти участі зацікавлених сторін.

Деякі вчені пропонують доповнювати законодавчі принципи такими принципами: 1. Максимальне врахування законних інтересів усіх осіб при розробленні стандартів. 2. Перевага застосування міжнародного стандарту при розробленні національних. 3. Неприпустимість створення перешкод виробництву, обороту продукції. 4. Відповідність стандартів технічним регламентам. 5. Однакове застосування стандартів [55, с. 106]. Вважаємо, що ці принципи лише уточнюють перелічені вище, нічим не доповнюють їх зміст, а тому не беруться нами до уваги. На нашу думку, в законодавстві України необхідно уніфікувати принципи стандартизації та викласти у дещо іншому вигляді та порядку:

1. Добровільне застосування стандартів та забезпечення умов для їx однакового застосування. Національний стандарт застосовується на добровільній основі рівним чином і в рівній мірі, незалежно від країни або місця походження продукції, виконання робіт і надання послуг.

2. Застосування міжнародного стандарту як основи для розроблення національного стандарту. Виняток можуть становити випадки, коли відповідність вимогам міжнародних стандартів неможливо внаслідок невідповідності їх вимог кліматичним, географічним або технічним особливостям країни. 
3. Збалансованість інтересів сторін, що розробляють, виготовляють i споживають продукцію. Учасники робіт зі стандартизації, виходячи 3 можливостей виробника продукції і виконавця послуг, з одного боку, та вимог споживача - 3 іншого, повинні знайти консенсус, який розуміється як відсутність заперечень із суттєвих питань у більшості заінтересованих сторін.

4. Динамічність і випереджувальний розвиток стандарту. Науковотехнічний процес вносить постійні зміни у діяльність людей і у вироблену продукцію та послуги. Стандарти повинні адаптуватися до змін, що відбуваються, більше того, носити випереджаючий характер, щоб не стримувати господарський розвиток країни.

5. Ефективність стандартизації. Застосування нормативних документів має давати економічний та/або соціальний ефект. Безпосередній економічний ефект дають стандарти, що ведуть до економії ресурсів, технічної та інформаційної сумісності, підвищення надійності. А соціальний ефект дають стандарти, спрямовані на забезпечення безпеки життя та здоров'я людей, навколишнього середовища. Найвищим $є$ той рівень ефективності, коли присутні обидва ефекти, та вони не суперечать один одному.

6. Принцип гармонізації. Даний принцип передбачає неприпустимість таких стандартів, які б суперечили технічним регламентам. 3 метою зняття бар'єрів у міжнародній торгівлі необхідне створення ідентичних документів, розроблених для одного і того самого об'єкта.

7. Чіткість формулювань положень стандарту. Можливість двозначного тлумачення може призвести до серйозних порушень і наслідків, у тому числі до втрати регулюючого впливу.

Діяльність зі стандартизації здійснюється на різних рівнях. Рівні стандартизації розрізняються залежно від того, учасники якого географічного, економічного, політичного регіону світу будуть використовувати стандарт. У ст. 6 Закону України «Про стандартизацію» виділяють два рівні: національний та на рівні підприємств. Зокрема, на національному рівні орган стандартизації приймає 
національні стандарти та кодекси усталеної практики, на другому рівні підприємства, установи та організації, що здійснюють стандартизацію, приймають стандарти, кодекси усталеної практики та ТУ.

Ми виділяюємо три рівні: міжнародний (участь відкрита для відповідних органів будь-якої країни); регіональний (тільки для відповідних органів держав одного географічного, політичного або економічного регіону); національний (в одній конкретній державі).

Міжнародна стандартизація - стандартизація, участь у якій є відкритою для відповідних органів усіх країн. У роботі з міжнародної стандартизації можуть брати участь кілька (дві чи більше) суверенних держав. Результатом роботи 3 міжнародної стандартизації є міжнародні стандарти, прийняті ISO.

Регіональна стандартизація - стандартизація, участь у якій є відкритою для відповідних органів країн лише одного географічного або економічного регіону. Результатом роботи з регіональної стандартизації є регіональні стандарти, які прийняті регіональною організацією зі стандартизації. Підвидом регіональної є міждержавна стандартизація, тобто стандартизація, участь у якій беруть окремі країни, наприклад СНД. Результатом роботи 3 міждержавної стандартизації $є$ ГОСТ, які прийняті країнами, що приєдналися до Угоди про проведення погодженої політики в галузі стандартизації, метрології та сертифікації і застосовуються ними безпосередньо. Міждержавні стандарти діють в усіх країнах СНД. Міждержавна стандартизація може бути прикладом для регіональної стандартизації, а стандарти 3 позначенням індексу ГОСТ - регіональними стандартами, що діють у певній географічній зоні.

Національна стандартизація - стандартизація, яка здійснюється на рівні однієї певної держави. Результатом роботи 3 національної стандартизації є національні нормативні документи, прийняті національним органом зі стандартизації певної держави та чинні для усіх суб’єктів на території цієї держави.

На національному рівні в Україні діють такі види стандартизації: національна, відомча та стандартизація організацій. Національна стандартизація 
здійснюється урядовими органами і поширюється на всі підприємства держави, незалежно від форми власності й підпорядкування. Результатом роботи є національні нормативно-технічні документи, які застосовують суб'єкти господарювання незалежно від форм власності й підпорядкованості, на діяльність яких поширюються ці документи. Відомча стандартизація здійснюється органами, компетентними в даній галузі економіки країни. Результатом роботи є відомчі нормативно-технічні документи, які поширюють свою чинність на певну галузь економіки. Стандартизація організацій застосовується суб'єктами господарювання. Результатом роботи $є$ нормативно-технічні документи організацій, які застосовують суб'єкти господарювання сфери керування органу, що їх прийняв, та їхніх підприємств-суміжників, а також інших суб’єктів господарювання, на діяльність чи результати діяльності яких поширюється чинність зазначених нормативно-технічних документів, за умови отримання згоди на їхнє застосовування від органу, що їх прийняв.

Інколи ці рівні класифікують як види [55, С. 105; 66, с. 81-82]. Відрізняють також:

1) параметричну стандартизацію, що застосовується для того, щоб здійснити оптимізацію, встановити параметри продукції, тобто кількісні

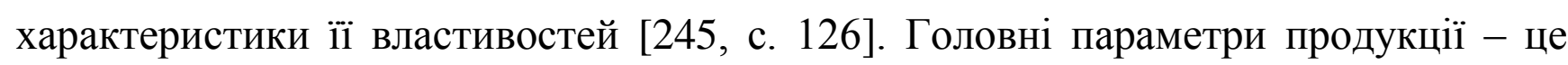
характеристики, що визначають призначення та умови використання продукції. Наприклад: розмірні параметри (розмір одягу, розмір приладу); рангові параметри (маса); параметри продуктивності (продуктивність верстатів); енергетичні параметри (потужність двигуна). Кожна продукція характеризується низкою параметрів, які називаються параметричним рядом. Наприклад, європейський жіночий розмір одягу «S»: обхват грудей $88 \mathrm{~cm}$, обхват талії $72 \mathrm{~cm}$, обхват стегон 96 см (EN 13402 «Size designation of clothes»). Ці дані виведені на основі антропометричних вимірювань великого числа жінок і оброблені методами математичної статистики. Такий метод застосовують для кожної продукції певного призначення, принципу дії і конструкції; 
2) комплексну стандартизацію, що встановлює i застосовує системи взаємопов'язаних вимог, як до самого об’єкта стандартизації, так і до окремих його елементів. Наприклад, щодо продукції - це вимоги до якості готової продукції і якості сировини для їі виготовлення, а також умов зберігання і споживання [262, с. 66-67];

3) випереджувальну стандартизацію, що відповідає однойменному принципу та передбачає встановлення підвищених по відношенню до досягнутого на практиці рівню норм і вимог до об’єктів стандартизації, які повинні стати оптимальними в майбутньому часі. Необхідність у такому виді стандартизації пов'язана 3 тим, щоб запобігти створенню технічних бар'єрів, гальмуванню технічного прогресу, оскільки для того, щоб розробити нові вимоги може знадобитися певний час, що може позначитися на економіці того чи іншого підприємства, а інколи на цілих сферах господарської діяльності [7, с. 17; 100, с. 10; 192, с. 13]. У зв'язку з цим і необхідна випереджувальна стандартизація для перспективних видів продукції;

На нашу думку, стандартизація проявляється як у статиці, так і динаміці. У статичному стані стандартизація закріплює положення, стандарти, регламенти та інші вимоги. У динаміці стандартизація працює у вигляді порівняння документально закріплених вимог та існуючих об’єктів стандартизації. Такі процедури називають оцінкою відповідності, результатом якої є видача документа про відповідність, яка грунтується на прийнятому після критичного огляду рішенні про те, що виконання визначених вимог було доведене (ст. 1 Закону України «Про технічні регламенти та оцінку відповідності»). Стандартизація у іiі класичному (технічному) розумінні розглядалася лише у статиці, що не дозволяло i не дозволяє оцінити досягнення мети стандартизації та результат 3 метою господарської діяльності. Саме тому, реалізуючи свою гуманістичну та соціальну функцію, Україна запровадила процедури підтвердження відповідності товарів і послуг вимогам стандартизації. Вважаємо, що таке підтвердження є складовою частиною стандартизації як процесу та одночасно застосовується як додатковий 
інструмент регулювання господарської діяльності. Оцінка відповідності має обов'язковий характер лише у разі чіткого зазначення у технічних регламентах (ст. 14 Закону України «Про технічні регламенти та оцінку відповідності»). Цією процедурою підтверджується виконання визначених вимог, що стосуються продукції, процесу, послуги, системи, особи чи органу. Законодавство України добровільною називає оцінку відповідності поза вимогами технічних регламентів, оскільки вона здійснюється на добровільних засадах, у будь-яких формах, включаючи випробування, декларування відповідності, сертифікацію та інспектування, та на відповідність будь-яким заявленим вимогам (ст. 24 Закону України «Про технічні регламенти та оцінку відповідності»).

На нашу думку, добровільною можна вважати ту оцінку, що проводиться на основі внутрішніх вимог підприємства чи іншого суб'єкта господарської діяльності. Вважаємо, що документальне зазначення необхідності проведення оцінки відповідності (у договорах, при визначенні конкурсних, тендерних умов тощо) слід вважати обов'язковою. Підтвердження відповідності товарів і послуг має подвійну природу та може ставати як імперативом, що застосовується при статичному закріпленні вимог, так і диспозитивом, який використовують суб'єкти господарської діяльності. Це може бути і органічне поєднання імперативу та диспозитиву. Тоді держава реалізує свої функції із охорони життя та здоров'я людини і довкілля, а суб’єкт господарської діяльності забезпечує собі більш вигідне становище на ринку, вихід на інші ринки збуту тощо.

Окремо існують процедури підтвердження відповідності товарів (послуг), уживання або використання яких може створити небезпеку для життя та здоров'я людини чи навіть довкілля. Такі товари i послуги зазвичай віднесені законодавством України до спеціально регульованої сфери та включені до спеціального реєстру. Підтвердження відповідності товарів і послуг, що містяться у таких переліках, відбувається шляхом застосування обов'язкових або добровільних процедур відповідності представленої продукції стандартам та/чи вимогам інших нормативно-технічних документів. Обов'язковими $є$ такі, що 
прописані у конкретних технічних регламентах $\mathrm{i}$ забезпечуються шляхом застосування національних стандартів та/або технічних специфікацій, посилання на які містяться у відповідних технічних регламентах. При обов'язковому підтвердженні відповідності у технічному регламенті чітко зазначаються способи відповідності: 1) відповідність нормативно-технічним документам $є$ єдиним способом або 2) така відповідність є одним із способів задоволення відповідних вимог технічного регламенту (ст. 11 Закону України «Про технічні регламенти та оцінку відповідності»). Тобто може застосовуватися презумпція відповідності об’єктів оцінки національним стандартам, перелік яких затверджений відповідним центральним органом виконавчої влади. Об'єктами оцінки відповідності можуть ставати не лише конкретний матеріал, продукція, установка, процес та/чи послуга, а й система, особа чи орган, щодо яких застосовується оцінка відповідності.

Здійснення добровільної оцінки відповідності не встановлюється технічними регламентами. Таке підтвердження відповідності здійснюється на добровільних та/чи договірних засадах, у будь-яких формах, включаючи випробування, декларування відповідності, сертифікацію та інспектування, а також підтвердження відповідності будь-яким заявленим вимогам. Добровільне підтвердження відповідності забезпечує суб'єкту господарської діяльності привабливість продукції для споживача, підвищення конкурентоспроможності продукції, надає переваги під час участі у тендерах, впевненість виробника або постачальника продукції в тї якості.

Законодавство України передбачає, що документами про відповідність є декларація (в тому числі декларація про відповідність), протокол (у тому числі протокол випробувань), звіт, висновок, свідоцтво, сертифікат (у тому числі сертифікат відповідності) або будь-який інший документ, що підтверджує виконання визначених вимог, які стосуються об'єкта оцінки відповідності (ст. 1 Закону України «Про технічні регламенти та оцінку відповідності»). Усі перелічені документи відіграють значну роль при виведенні товарів і послуг на ринок, у тому числі при прийнятті українською митницею рішення про пропуск 
тієї чи іншої продукції на територію країни. Часто документ про відповідність вимагають доброчесні суб'єкти господарської діяльності, адже внутрішній контроль за якістю може допускати лише перевірені товари та послуги, що є складовою успішного і безпечного ведення бізнесу та надає можливість уникнути (попередити) непередбачувані витрати.

3 метою отримання конкурентних переваг суб’єкти господарської діяльності, що отримали документ про відповідність, мають право використовувати знак відповідності [186]. Йдеться про спеціальне інформаційне маркування, за допомогою якого виробник зазначає, що продукція відповідає вимогам, які застосовуються до зазначеної продукції та визначені в технічних регламентах.

Підтвердження відповідності за допомогою процедури оцінки часто $є$ необов'язковим (додатковим) етапом стандартизації, що може завершити процес правореалізації або створити передумови для настання як позитивних, так i негативних наслідків для суб’єктів господарської діяльності.

Слід зазначити, що стандартизачія проявлясться як у статищі, так $i$ в динамічі. У статичному стані стандартизація закріплюе положення, стандарти, регламенти та інші вимоги. У динаміщі стандартизаџія пращює у вигляді порівняння документально закріплених вимог та існуючих об'єктів стандартизачіï. Як вже вказувалося, стандартизачія у іï класичному (технічному) розумінні розглядається лище у статиці. Ми пропонуємо нове визначення стандартизації як діяльності, щзо полягає в установленні $i$ застосуванні положень для загального та неодноразового використання щэодо наявних чи потенційних завдань і спрямована на досягнення оптимального ступеня впорядкованості в певній сфері суспільного життя для забезпечення мети стандартизації. Стандартизація включає в себе технічне регулювання та оичнку відповідності.

Доволі часто побутує думка про охоплення технічним регулюванням сфери стандартизації. Варто проаналізувати детальніше співвідношення стандартизаціятехнічне регулювання. 
За визначенням Закону України «Про технічні регламенти та оцінку відповідності» технічним регулюванням $є$ правове регулювання відносин у сфері визначення та виконання обов'язкових вимог до характеристик продукції або пов'язаних 3 ними процесів та методів виробництва, а також перевірки їх додержання шляхом оцінки відповідності та/або державного ринкового нагляду і контролю нехарчової продукції чи інших видів державного нагляду (контролю). Тобто технічне регулювання $є$ частиною правового регулювання, яке традиційно (усталено) розуміється як упорядкування суспільних відносин, що здійснюється державою за допомогою права і сукупності правових засобів, з їх юридичним закріпленням, охороною та розвитком. Його ознаками є:

1) правове регулювання $є$ різновидом соціального регулювання, що застосовується тоді, коли йдеться про ті суспільні відносини, функціонування яких неможливо без використання правових засобів;

2) набуття для відносин між суб’єктами правової форми, що має державновладний характер, тобто в юридичних нормах держава вказує міру можливої та належної поведінки;

3) правове регулювання має конкретний та цілеспрямований характер, тому що завжди пов'язане з реальними відносинами та спрямоване на задоволення законних інтересів суб’єктів права;

4) правове регулювання здійснюється за допомогою правових засобів, які забезпечують його ефективність та гарантують доведення норм права до їх виконання.

Кореспондуючи ці ознаки на технічне регулювання, отримуємо:

1) застосування правових засобів щодо відносин у сфері визначення та контролю вимог до продукції і послуг;

2) формою закріплення вимог $є$ технічний регламент, що $є$ нормативноправовим актом, в якому визначено характеристики продукції або пов'язані 3 ними процеси та методи виробництва, включаючи відповідні процедурні положення, додержання яких є обов'язковим. Він може також включати або 
виключно стосуватися вимог до термінології, позначень, пакування, маркування чи етикетування в тій мірі, в якій вони застосовуються до продукції, процесу або методу виробництва;

3) регламентування конкретних відносин 3 чітко визначеною метою: правове регулювання відносин у сфері визначення та виконання обов'язкових вимог до характеристик продукції або пов'язаних 3 ними процесів та методів виробництва;

4) правовими засобами $є$ перевірка додержання вимог шляхом оцінки відповідності та/або державного ринкового нагляду i контролю нехарчової продукції чи інших видів державного нагляду (контролю).

Якщо йдеться про стандартизацію, то вона $\epsilon$ частиною правового регулювання і одночасно виходить за його межі та надає можливість на певному етапі впорядковувати суспільні відносини 3 допомогою інших соціальних регуляторів (звичаїв, моральних, релігійних та корпоративних норм тощо). У разі потреби вимоги, що встановлюються соціальними регуляторами, можуть звужуватися до власне правових норм і вимог та забезпечуватися державою для отримання максимального ефекту чи захисту прав (інтересів) окремих соціальних груп, довкілля тощо.

Ознаками соціального регулювання є: 1) наявність кола регулювання суспільства; 2) реалізація безпосереднього впливу на поведінку і діяльність соціальних суб'єктів, витіснення і блокування деструктивних форм їх вияву; 3) пов'язаність з установленням конкретних загальносоціальних прав і обов'язків суб'єктів; 4) наявність мети: впорядкування суспільних відносин, подолання конфліктів і забезпечення компромісу між людьми та їх соціальними групами; 5) всезагальність, тобто поширення соціального регулювання на всіх суб'єктів громадянського суспільства; 6) здійснення 3 допомогою спеціальних засобів; 7) гарантування заходами соціального примусу.

Соціальне регулювання може бути внутрішнім (совість, переконання) та зовнішнім (суспільна мораль), стихійним (демографічні зміни, міграційні 
процеси, економічні кризи) і волевстановленим (владновольовим), нормативним (визначає норми, які $є$ правилами поведінки, що забезпечуються соціальним примусом) і ненормативним (оцінювальним) - здійснюється за допомогою історично складених матеріальних, політичних, соціально-культурних цінностей; директивним - шляхом адміністративної команди; інформаційним - за допомогою засобів масової інформації, Інтернету як глобальної телекомунікаційної мережі інформаційних і обчислювальних ресурсів); загальним (визначає правила поведінки для усіх) та індивідуальним (застосовує загальні норми для конкретної особи чи конкретного кола осіб).

У теорії права та юридичній деонтології зазвичай говорять про соціальне регулювання, що здійснюється за допомогою норм різної природи та походження: технічних, моральних, релігійних, корпоративних, звичаєвих тощо.

Природа технічного регулювання - це правове регулювання, тобто частина, окремий вид соціального регулювання. Природою стандартизації є соціальне регулювання у вигляді організуючої діяльності суспільства 3 метою більш злагодженого функціонування спільноти чи їі частини [180, с. 125-126].

Схематично це виглядає так:

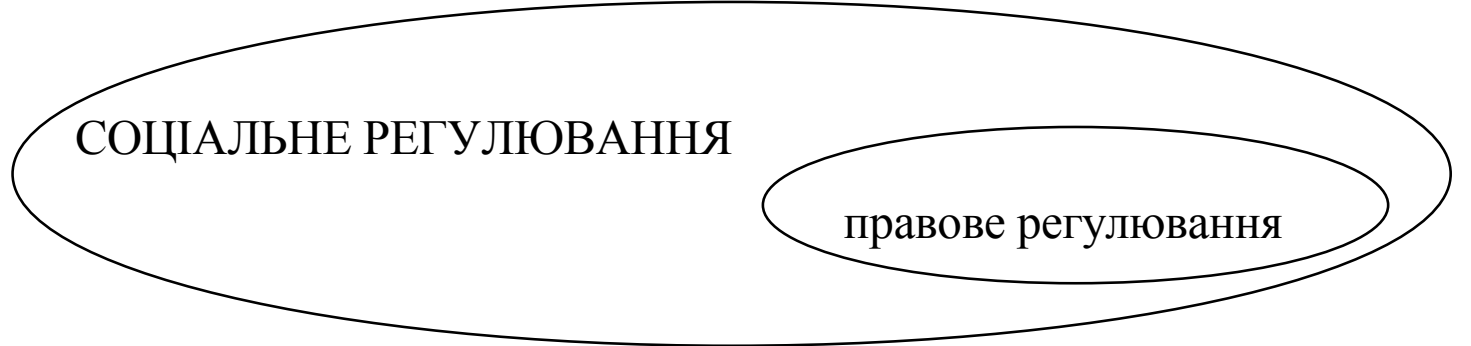

Схема 1. Співвідношення соціального та правового регулювання

Соціальне регулювання має на меті не лише регулювання, але й організацію оцінки (зовнішньої та самооцінки), одночасно воно має не лише статично закріплювати вимоги, але дозволяти їх реалізовувати. Ті норми (вимоги) суспільства, що не є витребуваними, відмирають, та існують лише у вигляді історичних фактів, або видозмінюються та існують в так званій новій редакції. Те саме ми можемо сказати про стандартизацію та іï вимоги: ті, що вже не $\epsilon$ 
потрібними, скасовуються, а ті, що потребують оновлень, змінюються і продовжують здійснювати свої цілі. У разі потреби нормативного регулювання вимог, вони перетворюються на норми права, що закріплюються у нормативноправових чи нормативно-технічних актах та можуть забезпечуватися юридичними засобами. Таким чином, ми можемо говорити про множинність видів діяльності, що $є$ похідними від стандартизації, про що вже йшлося вище (технічне регулювання, оцінка відповідності, нормування, типізація, ринковий нагляд тощо).

У країнах ЄС говорять про наявність технічних бар'єрів у торгівлі, але вирішують ці проблеми з допомогою засобів стандартизації. За Новим підходом та супутніми директивами (наприклад, EN 45020:2004, Standardization and related activities - General vocabulary (ISO/IEC Guide 2:1996; EN 45020:1998)) існують поняття «standardization», «regulation» та «technical regulation». Наводимо їх визначення в оригіналі та у власному перекладі:

\begin{tabular}{|c|c|}
\hline $\begin{array}{l}\text { Standardization - Activity of establishing, } \\
\text { with regard to actual or potential } \\
\text { problems, provisions for common and } \\
\text { repeated use, aimed at the achievement of } \\
\text { the optimum degree of order in a given } \\
\text { context }\end{array}$ & $\begin{array}{l}\text { Стандартизація - Діяльність із } \\
\text { встановлення положень для загального } \\
\text { і багаторазового використання, } \\
\text { спрямована на досягнення } \\
\text { оптимального ступеня порядку щодо } \\
\text { фактичних або потенційних проблем }\end{array}$ \\
\hline $\begin{array}{l}\text { Regulation - Document providing binding } \\
\text { legislative rules, that is adopted by an } \\
\text { authority }\end{array}$ & $\begin{array}{l}\text { Регламент (правила) - Документ, що } \\
\text { забезпечує обов'язкові законодавчі } \\
\text { правила, що приймаються органом } \\
\text { влади }\end{array}$ \\
\hline $\begin{array}{l}\text { Technical regulation - Regulation that } \\
\text { provides technical requirements, either } \\
\text { directly or by referring to or incorporating } \\
\text { the content of a standard, technical } \\
\text { specification or code of practice }\end{array}$ & $\begin{array}{l}\text { Технічний регламент - Положення, яке } \\
\text { містить технічні вимоги безпосередньо } \\
\text { або шляхом включення посилання на } \\
\text { вміст стандарту, технічної специфікації } \\
\text { або кодексу практики }\end{array}$ \\
\hline
\end{tabular}


Прослідковується розуміння стандартизації як організуючої активної діяльності у сфері впорядкування, а регламенти та технічні регламенти європейці розуміють як акти регулювання [181, с. 62-64]. Вбачається, що дослівний переклад «technical regulation» як «технічне регулювання» призвів до помилкового розуміння, що в Європі діє система технічного регулювання поряд із стандартизацією. На офіційній сторінці CEN роз'яснюється різниця між стандартизацією та законодавством. Стандарти розробляються через процес співпраці зацікавлених сторін, затверджуються та публікуються визнаними органами стандартизації. Положення та інші види актів законодавства приймаються урядами на національному або регіональному рівні або наднаціональними та/або міждержавними організаціями, такими як СС. Крім того, використання стандартів $\epsilon$ добровільним, тоді як норми є обов'язковими та юридично закріпленими [291, c. 185-186]. Тобто стандартизація не така ж, як законодавство.

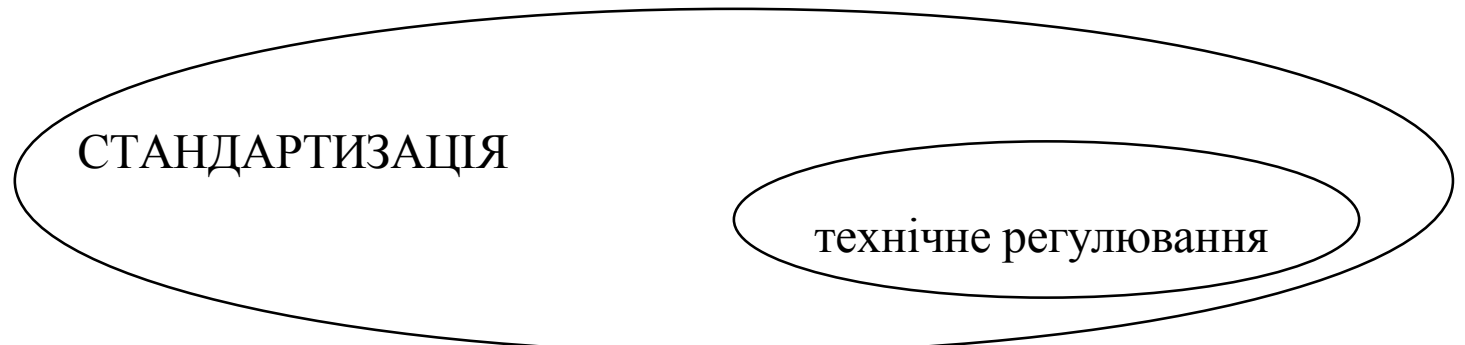

Схема 2. Співвідношення стандартизації та технічного регулювання

3 викладеного вище доходимо висновку, що стандартизація походить від соціального регулювання, породжує норми технічного, організаційного чи іншого впорядковуючого характеру, які можуть переходити (перетворюватися) в норми права. Водночас технічне регулювання $є$ похідним із правового регулювання (частини соціального регулювання) та породжує технічні регламенти, що є нормативно-правовими актами - частиною національного законодавства України, у тому числі господарського. Стандартизація як діяльність створює вимоги (норми), що можуть набувати різних форм (закріплюватися у різних видах документів: від стандартів підприємства до норм законодавства). 


\section{2 Акти регулювання у сфері стандартизації}

32003 р. стандартизація стала одним із елементів регулюючого впливу держави на господарські відносини.

Загальновідомо, що господарське законодавство становить нормативну основу господарського правопорядку - правил організації, безпосереднього здійснення та управління господарською діяльністю. Переважна більшість вчених вважає, що господарське законодавство - це сукупність нормативно-правових актів i правових норм, які регулюють відносини щодо безпосереднього здійснення господарської діяльності, управління та організації такої діяльності [1,c. 4-5; 83,с. $412-413 ; 87$, c. $33 ; 86$, c. $8 ; 88$, c. $60 ; 122$, c. 12,$19 ; 163$, c. $242-243 ; 237$,c. $18-19,21$; 239, ,c. $26-27 ; 254$, с. $28 ; 259$,с. 10-12]. Інші вчені вважають, що до господарського законодавства слід включати лише закони, а підзаконні та локальні акти не відносять до нього [103, с. 294-295]. Деякі вчені пропонують включати в масив законодавчих актів у сфері господарської діяльності договори, статути, засновницькі договори тощо [270, с. 27-28].

На нашу думку, слід дотримуватися доктринальної позиції та визначати господарське законодавство як сукупність нормативно-правових актів та правових норм, які регулюють господарські відносини (відносини щодо безпосереднього здійснення господарської діяльності та управління такою діяльністю, в тому числі ії організацію).

Воно має такі ознаки:

1. Значна розгалуженість і присутність великої кількості нормативних актів.

2. Перевага в господарському законодавстві комплексних нормативних актів, що містять норми різних галузей права (господарського, цивільного, фінансового, трудового, екологічного тощо), але мають спільний предмет правового регулювання.

3. Кодифікованість господарського законодавства, основою якого є ГК України. 
4. Наявність значної кількості нормативних актів обмеженої сфери дії щодо конкретних суб'єктів господарської діяльності.

5. Наявність нормативних актів з різним ступенем адекватності сучасному стану ринкових відносин в Україні та світі (принагідно варто зазначити, що у сфері стандартизації вже зведено до мінімуму кількість актів колишнього СРСР).

6. Стрімкість та безсистемність прийняття актів законодавства, що зумовлено суб'єктивними чинниками.

Господарське законодавство складається 3 великого масиву взаємопов'язаних між собою нормативно-правових актів різної юридичної сили, що регулюють господарські відносини. У своїй сукупності ці нормативно-правові акти складають систему господарського законодавства [215, с. 115].

Суб’єкти господарювання та інші учасники відносин стандартизації здійснюють свою господарську діяльність у межах встановленого правового порядку, який грунтується на Конституції України, визначається ГК України та іншими нормативно-правовими актами господарського законодавства. Діючу систему господарського законодавства зазвичай поділяють на загальні норми та щодо окремих видів продукції чи послуг (беручи за основу поділу предмет регулювання). Так само можна виділяти загальні норми господарського законодавства, що регулюють стандартизацію, та спеціальне законодавство, що регулює стандартизацію окремих товарів, послуг чи видів господарської діяльності у конкретно визначеній сфері. За юридичною силою нормативних актів система господарсько-правових актів, що регулюють стандартизацію, складається з:

1) положень Конституції України;

2) законів України, що регулюють господарські відносини, провідне місце серед яких посідають кодифіковані акти: ГК України (визначає основні засади господарювання та особливості правового регулювання в галузі стандартизації), положення ЦК України, що мають застосовуватися на субсидіарних засадах (щодо матеріальної відповідальності за порушення вимог стандартизації), спеціальні закони «Про стандартизацію», «Про технічні регламенти та оцінку 
відповідності», «Про державний ринковий нагляд i контроль нехарчової продукції» тощо;

3) підзаконних актів (Указу Президента України «Про посилення відповідальності за порушення правил, норм і стандартів, що відносяться до забезпечення безпеки дорожнього руху», актів Уряду України (наприклад, постанова Кабінету Міністрів України «Про затвердження національного стандарту ДСТУ Б В.2.3-8-2003 «Споруди транспорту. Дорожні покриття. Методи вимірювання зчіпних якостей») та інших);

4) відомчих нормативних актів, що видаються компетентними міністерствами та іншими урядовими установами щодо регулювання діяльності певної галузі народного господарства або певної сфери економіки (наприклад, накази про затвердження національних стандартів України, прийняття національних стандартів України, гармонізованих 3 міжнародними стандартами i EN, та скасування національних стандартів України і нормативних документів в Україні);

5) регіональних нормативних актів, що приймаються органами місцевого самоврядування відповідно до делегованих державою повноважень і встановленого порядку (регіональні правила забудови населених пунктів i територій області, затвердження яких входить до компетенції обласної ради народних депутатів відповідно до ст. 11 Закону України «Про основи містобудування»; регіональні будівельні норми та правила);

6) локальних нормативних актів, що приймаються (укладаються) безпосередньо суб’єктами господарювання або їх засновниками (установчі та внутрішні правові документи суб'єктів господарських відносин) [215, с. 111; 239, с. 28]. Той самий установчий договір може містити вимоги дотримання нормативнотехнічних документів у господарській діяльності суб’єктів підприємництва.

Джерелом господарського права можуть бути i міжнародні договори України (універсальні, міжнародних організацій, двосторонні), ратифіковані Верховною Радою України або укладені за ії згодою, інші міжнародні документи.

Своєрідним джерелом права у сфері стандартизації є звичаї ділового обороту, 
в тому числі міжнародні торговельні звичаї (згідно зі ст. 2 Закону України «Про режим іноземного інвестування», оцінка окремих видів іноземних інвестицій може здійснюватися за міжнародними торговими звичаями; ст. 7 Цивільного кодексу України закріплює принцип застосування звичаїв ділового обороту, що стосується сфери підприємництва, тобто комерційної господарської діяльності). ГК України допускає таке регулювання і в ст. 38 визначає основні засади застосування правил професійної етики у конкуренції, що можуть використовуватися при укладенні договорів, розробленні установчих та інших документів суб’єктів господарювання (тобто $\epsilon$ узвичайненнями, що застосовуються лише за згодою суб’єктів господарювання).

Регулювання відносин у сфері господарювання може здійснюватися і за допомогою правил професійної етики у сфері конкуренції, що приймаються саморегулівними заінтересованими організаціями за погодженням 3 Антимонопольним комітетом України (ч. 1 ст. 38 ГК України). Проте такі правила, так само, як і правила професійної етики у сфері конкуренції, належать до узвичайнень та застосовуються за умови посилання на них у договорі, установчих та інших правових документах суб'єктів господарювання (ч. 2 ст. 38 ГК України).

Норми та вимоги стандартизації формуються об'єктивно і не можуть за волею законодавства переміщатися у межі іншого правового інституту, що не заперечує наявність відсильних норм господарського права, де зазначається необхідність або обов'язковість застосування конкретних вимог стандартизації. Стандартизація в господарському праві має свою специфічну конструкцію та єдині принципи для застосування усіх ï̈ вимог:

1) норми і вимоги стандартизації забезпечують усі сфери господарської діяльності, встановлюючи рівні вимоги для виготовлення окремих типів чи видів товарів, надання типових послуг;

2) свобода підприємницької діяльності може обмежуватися вимогами щодо безпеки товарів (послуг) для людини чи довкілля, а може забезпечуватися шляхом добросовісного виконання вимог; 
3) адаптація вимог національної стандартизації до світових норм технічного регулювання забезпечує вільний рух товарів (послуг) на внутрішньому та зовнішніх ринках;

4) втручання держави дозволяється як оптимальне державне регулювання, оскільки ступінь державного регулювання залежить від стану економіки, внутрішнього та зовнішнього становища країни (більш значний за кризового стану економіки, стихійного лиха та інших негараздів, а послаблення регулювання - у разі стабільного стану економіки);

5) захист національного товаровиробника досягається впровадженням новітніх норм і вимог у максимально стислі терміни або шляхом адаптації вимог міжнародних стандартів, директив тощо;

6) втручання держави є доцільним, обгрунтованим і законним лише у тому разі, якщо господарська діяльність створює загрозу життю та здоров’ю людини, довкіллю чи національній безпеці.

Стандартизація має можливість формувати загальні поняття та загальні засади у межах актів, що регулюють господарську діяльність у сфері стандартизації. Такими $є$ системоутворюючі ДСТУ 1.1:2015 Національна стандартизація. Стандартизація та суміжні види діяльності. Словник термінів; ДСТУ 1.2:2015 Національна стандартизація. Правила проведення робіт 3 національної стандартизації; ДСТУ 1.7:2015 Національна стандартизація. Правила та методи прийняття міжнародних і регіональних нормативних документів.

Зазвичай, акти господарського законодавства мають складний характер, що пов'язано з необхідністю врегулювати широке коло правовідносин. Це можуть бути правові норми різного виду (типу), об'єднані одним предметом (наприклад, відносини 3 виготовлення продукції потребують нормативно-правового регулювання, що пов'язане 3 господарськими договорами певного виду, визначенням суб'єкта господарювання певної господарсько-правової форми, необхідністю ліцензування господарської діяльності, створенням органу господарського управління зі спеціальними функціями внутрішнього контролю 
тощо). Це пов'язано 3 тим, що господарська діяльність охоплює, як правило, кілька видів (сфер) діяльності, що спричиняють виникнення правовідносин, що прямо чи опосередковано потребують урахування норм інших галузей права.

До загальних ознак належать:

- встановлення господарсько-правових норм компетентними суб'єктами (залежно від юридичної сили та виду нормативно-правових актів, у яких містяться норми). Такими органами є: Верховна Рада України, Президент України, Кабінет Міністрів України, центральні органи державної виконавчої влади, обласні ради народних депутатів та обласні держадміністрації, міські (Київська та Севастопольська) ради і держадміністрації), господарські об’єднання та суб'єкти господарювання;

- офіційний, або легальний (встановлений законом), порядок прийняття таких норм (залежить від юридичної сили та виду нормативно-правових актів, у яких містяться норми);

- фіксація таких норм у спеціальних правових документах (ïx назва залежить від юридичної сили документа i, відповідно, від органу, що його приймає: закон, декрет, постанова, указ, наказ, положення, статут, договір, правила, рішення, розпорядження та ін.);

- адресування таких норм заздалегідь невизначеному колу осіб - усім потенційним чи зареєстрованим суб'єктам господарювання чи певної організаційно-правової форми, наприклад господарським товариствам, їх засновникам, учасникам, посадовим особам органів управління товариств (тобто цим нормам не притаманна індивідуальна персоніфікація - адресування конкретній особі).

Господарсько-правові норми характеризуються такою специфічною ознакою, що виокремлює їх від норм інших галузей права, як зміст: вони містять правила у сфері господарювання (щодо безпосереднього здійснення господарської діяльності та/або організації, управління такою діяльністю). Слід погодитися із загальноприйнятим визначенням, що господарсько-правові норми - 
це встановлені компетентними органами в офіційному порядку та зафіксовані в спеціальних правових документах індивідуально не персоніфіковані правила у сфері господарювання.

Різноманітність господарсько-правових норм зумовлює доцільність їх класифікації:

I. За структурою норм: 1) норми 3 традиційною структурою (гіпотеза, диспозиція і санкція); 2) норми з неповною структурою, що серед господарськоправових норм становлять більшість (у тому числі у сфері стандартизації);

II. За змістом: 1) норми-заборони (наприклад, заборона здійснення підприємницької діяльності 3 порушенням загальних вимог, у тому числі стандартизації (ч. 4 ст. 43 ГК України); 2) норми-принципи (наприклад, принцип свободи підприємницької діяльності (ст. 44 ГК України), що у поєднанні 3 вимогами стандартизації забезпечує належний порядок i можливість функціонування суб'єктів господарської діяльності); 3) норми-визначення (більшість прийнятих законів мають спеціальну статтю «Визначення термінів», у якій розкривається зміст основних термінів, що застосовуються. Так само у ст. 1 Закону України «Про стандартизацію» розкриваються усі визначення, що застосовуються у цьому законі); 4) компетенційні норми (наприклад, про компетенцію державного органу у сфері стандартизації); 5) техніко-економічні норми (визначають порядок здійснення певних технологічних процесів, параметри і вихідні величини господарської діяльності, норми амортизаційних відрахувань, державні стандарти, державні будівельні норми та правила, ТУ та інші вимоги стандартизації); 6) норми-рекомендації (не будучи юридично обов'язковими для суб'єктів господарювання, орієнтують їх та бажану для суспільства (держави) поведінку в сфері господарювання): типові статути чи договори, добровільні вимоги стандартизації.

Часто до норм господарського законодавства відносять технічні норми. Згідно з тлумачним словником семантика поняття «технічний»є такою: 1) той, що використовується в промисловості, техніці (розуміється як закони природи та 
неживі об'єкти середовища); 2) той, що відноситься до обслуговування техніки, їі використання; 3) не відповідальний, такий, що діє за вказівкою. Пропонуємо технічні норми в господарському праві визначати як обов'язкові правила, що об'єктивно визначаються рівнем техніки та використовуються в промисловості для обслуговування та використання об'єктів природного чи штучного походження з метою задоволення потреб людини та/чи інтересів суспільства.

Ознаками технічних норм є:

1) обов'язковість правил (тобто вони набули ознак юридичних норм в силу своєї значущості (наприклад, включення як вимоги безпеки на виробництві, стандарту протипожежної безпеки, якості продукції тощо) та можливості забезпечення їх виконання державою);

2) об’єктивно визначаються рівнем техніки (рівень визначається законами природи та техніки, а результат формулюється як «причинність-закономірність»);

3) використовуються в промисловості (виключність використання та обмеженість дії);

4) метою $є$ безпековий та нечітко виражений соціальний напрям регулювання.

Враховуючи вищенаведені ознаки сучасного господарського законодавства України, можна дійти висновку, що в ньому чимало застарілих, колізійних норм, а також прогалин, що зумовлено запровадженням в економіку України нових для неї ринкових відносин, які ще не зазнали відповідного законодавчого врегулювання. Зазначені обставини зумовлюють необхідність удосконалення господарського законодавства. Зокрема, гармонізацію (адаптацію) законодавства України 3 міжнародними стандартами регулювання відносин у сфері господарювання, законодавством міжнародних економічних союзів, до складу яких входить чи планує увійти Україна (включаючи й $Є С$ ). Так, Законом України «Про Загальнодержавну програму адаптації законодавства України до законодавства Європейського Союзу» від 16.03.2004 p. № 1629-IV та підзаконними нормативноправовими актами (Указом Президента України «Питання організації виконання Закону України «Про Загальнодержавну програму адаптації законодавства України 
до законодавства Свропейського Союзу» від 21.08.2004 p. № 965/2004, Положенням про Центр європейського та порівняльного права, затвердженим наказом Міністерства юстиції України від 28.10.2004 р. № 126/5 та іншими) передбачалася низка заходів, спрямованих на забезпечення реалізації цього напряму вдосконалення національного законодавства.

Повертаючись до процесу створення вимог стандартизації в сучасній Україні, слід зазначити, що він відповідає процесу нормотворення (правотворення), що є елементом правового регулювання будь-якої галузі права України та без якого неможна говорити про існування тих чи інших правовідносин (їх не буде закріплено). Правотворчість $є$ результатом об’єктивного розвитку суспільних відносин, безпосередньо спрямованим на їх врегулювання, що засновується на принципах науковості, професіоналізму, законності, демократизму, гласності, оперативності, гуманізму та планування [9, с. $67 ; 103$, с. $296-297 ; 205$, с. $29 ; 216$, с. $73-74 ; 221$, с. 5]. На аналогічних принципах засновується і нормотворення у сфері стандартизації.

Результатом діяльності нормотворення у сфері стандартизації є створення нормативно-технічних документів. Через нормативні документи стандартизація впливає на сфери діяльності людини, розвиток економіки країни, прискорення науково-технічного прогресу, економію та раціональне використання сировини, матеріалів, енергетичних ресурсів підвищення якості продукції (процесів, робіт, послуг). Сучасний рівень розвитку економіки України, потреба у корінних змінах матеріальних i соціальних умов життя народу висувають на перший план проблему якості. Поліпшення якості товарів (процесів, робіт, послуг) можливе тільки на основі стандартизації. Контролювати та підвищувати якість можливо тільки на основі нормативно-технічних документів, які встановлюють вимоги до якості та надійності, методів контролю і випробовувань продукції, створюють необхідну єдність, без якої неможливий подальший розвиток технічного рівня [6, с. 219 ; 55, с. 98; 243, с. 13]. Стандарти є критерієм при визначенні якості [21, с. 67; 79, с. $489 ; 80$, c. $196-198 ; 239$, c. $175-178]$. 
Нормативно-технічні документи містять показники, що можуть бути охарактеризовані кількісно та якісно [168, с. 187]. Вони звуться показниками стандартів і забезпечують таку категорію як якість [26, с. 51; 70, с. 96-97; 108,с. 97; 240, с. 52, 53]. Показники нормативно-технічних документів - це характеристики об'єктів стандартизації, що виражаються за допомогою умовних одиниць, позначень чи понять. До таких показників належать: відомості щодо розмірів виробів, хімічного складу, фізичних властивостей, маси, експлуатаційних характеристик, економічності, надійності, нешкідливості, безпеки тощо.

Усі нормативно-технічні документи містять як загальні, так і технічні норми, тобто правила ставлення людей до знарядь і предметів праці, до техніки та сил природи. Ці правила вказують на екологічні та економічні методи, прийоми та способи впливу людей на матеріальний світ, взаємодію з технічними і природними об'єктами [36, с. 496-497; 104, с. 78].

На практиці та в науковій літературі проблема стандартизації розглядається головним чином у техніко-економічному аспекті. Значення правового аспекту стандартизації недооцінюється. Сприймається лише відповідальність підприємств і працівників за випуск недоброякісної продукції на ринок. Проте правовий аспект цієї проблеми значно ширший i не обмежується питаннями вказаної відповідальності. Недооцінювання правового аспекту нормативно-технічних документів призвело до того, що правові засоби забезпечення дотримання вимог стандартизації застосовуються на практиці неефективно. Усталений в економіці «правовий нігілізм», перебільшення ролі правової заборони і недооцінка права як конструктивного, творчого, регулюючого фактора стало «гальмом» для розвитку національного виробництва, коли підприємства в основному тільки сплачують штрафи, не відшкодовують збитків, заподіяних внаслідок постачання та використання недоброякісних товарів і послуг.

Суб'єкти господарської діяльності також не розуміють своїх економічних переваг при використанні (застосуванні) вимог стандартизації. Стандартизація у господарській діяльності надає можливість встановлювати, що роль права не 
вичерпується лише встановленням і закріпленням технічних вимог у нормативнотехнічних документах. Значення правового регулювання за допомогою вимог стандартизації полягає також у впливі на поведінку окремих людей у суспільстві, що забезпечило б здійснення та додержання закріплених у правових нормах технічних вимог. Для цього, наприклад, встановлюється: загальний порядок приймання сировини, матеріалів і готової продукції визначеного рівня якості; регулюються відносини, які виникають у зв'язку з використанням вимірювальної техніки; передбачається відповідальність за порушення нормативно-технічних документів; регулюються відносини щодо якості товарів і послуг. Регулююча роль нормативно-технічних документів у цьому аспекті виявляється в закріпленні у правових нормах певних технічних вимог і забезпеченні правовими засобами, їх додержання при виготовленні й обігу товарів і наданні послуг. При додержанні технічних та інших вимог суб'єкти господарської діяльності виробляють (постачають) на ринок доброякісну продукцію (товари та послуги) [174]. А доброякісна продукція - це відповідність сукупності властивостей продукції вимогам стандартів, інших нормативно-технічних документів, умовам договорів [94, с. 170-172]. Хоча це визначення економічного характеру. В юридичній площині це поняття має значення як належна якість товару, роботи або послуги, тобто властивість продукції, яка відповідає вимогам, встановленим для цієї категорії продукції у нормативно-правових актах і нормативних документах, та умовам договору із споживачем (п. 13 ст. 1 Закону України «Про захист прав споживачів») [75]. Це стосується і відносин із організації праці на підприємствах 3 допомогою внутрішніх чи інших вимог, дотримання санітарно-гігієнічних вимог до робочого місця людини. Навіть відносини із заснування суб'єкта господарської діяльності регламентуються вимогами, що належать до стандартизованих (усталених) вимог (типові вимоги до змісту та розділів статуту).

На сьогодні чітке розмежування знань потроху нівелюється, що надає модливість поєднувати та застосовувати знання з інших, у тому числі технічних, сфер у галузі права. Часто у теорії господарського права виділяють технічні норми 
як вид норм господарського права [36, с. 497; 231, с. 284-286; 67, с. 50; 167, с. 13; 253 , с. 66]. Вважаємо, що при переході технічної норми у загальне правило поведінки вона набуває ознак юридичної норми, а тому виокремлювати такі норми як окремий вид немає ніякого сенсу. Деякі вчені ведуть мову про незмінність характеру технічних норм при переході їх до загальних правил, оскільки їх технічна сутність не змінюється. Основним аргументом такої наукової позиції $€$ неможливість забезпечення санкціями та застосування прямої відповідальності за порушення технічних норм [144, с. 88-89; 263, с. 120]. Слід не погодитися з такою позицією, оскільки сутність може й не змінюється, але норма має всі ознаки юридичної, у тому числі можливість застосування державного примусу. Наприклад, спеціалісти інспекції з питань захисту прав споживачів у Волинській області впродовж 2013 р. провели перевірки на дотримання вимог законодавства про захист прав споживачів і відповідність продукції вимогам стандартів у 219 суб'єктів господарювання, які здійснюють реалізацію непродовольчих товарів, та оштрафували 75 суб'єктів господарської діяльності на 62,6 млн. грн [235]. Перевіряючи дотримання технічних норм, було застосовано заходи державного примусу.

На нашу думку, при використанні стандартизації як засобу регулювання господарської діяльності йдеться також про використання нормативно-технічних документів як основних засобів такого регулювання. Інколи навіть можна прослідкувати переважність технічних норм перед юридичними у разі застосування принципу добровільності вимог стандартизації. Перевага юридичних норм перед технічними прослідковується тоді, коли принцип добровільності застосування стандартів може бути усунений, якщо того вимагає технічний регламент, що має форму закону. У такому разі говоримо про принцип чітко регламентованого державного обов'язкового регулювання господарської діяльності.

Поряд із цим прослідковуємо аналогії в ознаках нормативно-правового та нормативно-технічного акта. Так, відповідно до абз. 4 п. 1.4 «Порядку подання 
нормативно-правових актів на державну реєстрацію до Міністерства юстиції України та проведення їх державної реєстрації» нормативно-правовим актом $\epsilon$ офіційний документ, прийнятий уповноваженим на це суб'єктом нормотворення у визначеній законом формі та порядку, який встановлює норми права для неозначеного кола осіб і розрахований на неодноразове застосування. Ознаками є: 1) прийняття уповноваженим суб'єктом; 2) наявність певних процедур і порядку прийняття; 3) оформлення у вигляді офіційного документа; 4) багаторазовість застосування; 5) неперсоніфікованість.

Нормативно-технічні документи (акти) мають подібні ознаки: 1) приймаються спеціально уповноваженими суб'єктами (Верховною Радою України, Кабінетом Міністрів України, центральним органом виконавчої влади, суб'єктом господарської діяльності, міжнародним суб'єктом, що прямо передбачено у законодавстві України); 2) законодавством України та ДСТУ 1.1:2015, ДСТУ 1.2:2015, ДСТУ 1.7:2015 визначено процедури створення, уточнення, зміни або адаптації (гармонізації) вимог стандартизації; 3) акти, що не мають письмової форми, не стають тими вимогами, що визнаються як вимоги стандартизації; 4) неодноразовість застосування вимог випливає 3 ознаки систематичного використання; 5) застосування без персоніфікації прямо передбачено навіть тоді, коли йдеться про індивідуальне виготовлення товару (надання послуг), про пробну (тестову) партію товарів, оскільки прив'язка здійснюється не до особи, а до товару (послуги).

3 вказаного вище можна дійти висновку, що нормативно-технічний документ - це офіційний документ у сфері стандартизації, що прийнятий уповноваженим на це суб'єктом нормотворення у визначеній законом формі та порядку, який встановлює правила, загальні принципи та характеристики різного виду діяльності або іiі результатів для неозначеного кола осіб і розрахований на неодноразове застосування. Нормативно-технічні документи розробляються на об'єкти стандартизації, які є обов'язковими для використання в окремих галузях діяльності в установленому порядку та затверджуються компетентними органами. 
До нормативно-технічних документів належать стандарти, технічні регламенти, кодекси усталеної практики (настанови, правила, зведення правил), ТУ, регламенти, державні класифікатори, стандарти підприємств тощо.

Розглянемо детально основні види нормативно-технічних документів. Слово «стандарт» (від англ. Standard) в буквальному розумінні означає «норма», «зразок», «мірило», а в широкому - це зразок або еталон якості, через який держава здійснює наукове обгрунтоване управління якістю. Стандарт є основним нормативно-технічним документом у галузі стандартизації [98, с. 80]. Правильне визначення цього терміна має важливе значення. У ДСТУ 1.1:2015 цей термін має таке визначення: стандарт - документ, заснований на консенсусі, прийнятий визнаним органом, що встановлює для загального та неодноразового використання правила, настанов або характеристики щодо діяльності чи іiі результатів, і спрямований на досягнення оптимального ступеня впорядкованості у певній сфері.

Стандарти можуть бути розроблені як на матеріальні предмети (продукцію, еталони, зразки тощо), так і на норми, правила, вимоги до об'єктів організаційнометодичного та загально-технічного характеру [67, с. 51; 239, с. 175]. Стандарти $\epsilon$ результатом конкретної роботи зі стандартизації. Вони грунтуються на узагальнених досягненнях науки, техніки, практичного досвіду, являють собою визнані технічні правила і мають визначений юридичний статус на всіх рівнях управління економікою $[13$, с. $21 ; 193$, с. 45]. Стандарти розробляються і використовуються у зв'язку з тим, що відповідні кола суспільства (виробники, споживачі, торгівля) стикаються з проблемами, які вимагають спільних рішень. Стандарти базуються на загальновизнаних результатах науки, техніки і досвіду.

Інколи у наукових колах висловлюється думка, що стандарт повинен, крім цільового призначення з визначенням суто кількісних та якісних характеристик, мати ще й естетичну складову [127, с. $15 ; 242$, с. 93]. Основним аргументом такої позиції є те, що стандарт - це документ, виданий та затверджений офіційним органом для постійного використання, що містить керівництва, правила або 
характеристики, спрямовані на забезпечення оптимальних результатів. Такий результат у високорозвиненому суспільстві досягається, в основному, ергономікою (зручністю) та зовнішнім виглядом [80, с. 200-201; 209, с.91]. На нашу думку, ця позиція є правильною, оскільки завжди при здійсненні господарської діяльності буде враховуватися попит та вимоги суспільства, що забезпечує економічну вигоду суб'єкту господарської діяльності.

Наведемо класифікацію стандартів відповідно до рівнів стандартизації. Стандартизація (розробка, затвердження, прийняття та видання стандартів) проводиться на таких рівнях: компанії (стандарт підприємства); групи компаній (стандарт концерну); міністерства (галузевий стандарт); національному (наприклад національний стандарт України ДСТУ); регіональному (наприклад $\mathrm{EN})$; міждержавному (наприклад в рамках СНД); міжнародному (міжнародний стандарт ISO).

Стандарти на рівні компаній, груп компаній поширюються тільки на продукцію, що випускається на конкретному підприємстві або групі підприємств [80, с. 200-201; 209, с 91; 239, с. 176-176]. Підприємство розробляє стандарт з такими завданнями: встановити і декларувати підвищені вимоги в порівнянні з вимогами, прийнятими у конкурентів; регламентувати внутрішні вимоги, раціоналізувати процеси та операції; забезпечити гарантії споживачам (контрагентам та споживачам).

Національні стандарти розробляються національним органом зі стандартизації, галузеві - відповідними міністерствами та урядовими установами. Галузеві стандарти розробляються на продукцію за відсутності державних стандартів або за необхідності встановлювати вимоги, що перевищують чи доповнюють вимоги національних стандартів. Стандарти на національному та галузевому рівнях мають за мету: забезпечити потреби суспільства в розвитку за рахунок прийняття єдиних вимог на основі останніх досягнень науки і техніки; забезпечити захист здоров'я i життя споживачів, охорону навколишнього середовища, а також захист вітчизняного товаровиробника; усунути технічні бар’єри в торгівлі за рахунок прийняття міжнародних вимог. 
Розрізняють також гармонізований стандарт - це національний стандарт, який відповідає стандарту, розробленому міжнародною або регіональною організацією зі стандартизації. Міжнародні та регіональні стандарти приймаються відповідно міжнародними та регіональними організаціями зі стандартизації. Міжнародна стандартизація спрямована на полегшення торговельних i виробничих відносин у світі, що особливо актуально при становленні глобальних міжнародних ринків, таких як Єдиний Європейський, Північноамериканський, Азіатсько-Тихоокеанський. Регіональна стандартизація та їі стандарти спрямовані на захист інтересів окремого регіону. Спільнота суб'єктів, що застосовують стандартизацію, та державні органи часто прагнуть досягти схожих, навіть загальних цілей, особливо на європейському рівні. Ці цілі включають: розвиток єдиного ринку, підвищення конкурентоспроможності, сприяння світовій торгівлі, поліпшення добробуту громадян та захист навколишнього середовища. Тому не дивно, що органи стандартизації в Свропі співпрацюють 3 державними органами (в ряді випадків така співпраця полягає в розробці стандартів для підтримки законодавства та державної політики).

EN пропонують доступні і прості засоби для бізнесу, щоб вони відповідали європейським нормам. Правильно використовуючи гармонізовані стандарти, підприємства та інші організації можуть забезпечити відповідність вимогам Директив ЄC, наприклад, щодо безпеки певного товару чи послуги. Співвідношення між стандартизацією та законодавством на європейському рівні було розроблено відповідно до так званого нового підходу до технічної гармонізації та стандартів, яке було запроваджено у 1985 році. Суб’єкти господарської діяльності, споживачі та інші зацікавлені сторони в Європі отримують вигоду від поточної співпраці між регулюючими органами (установами $С С$ та $С \mathrm{ABT}$ ) та Свропейською системою стандартизації, що можна розглядати як певне партнерство між державним та приватним секторами.

Правова культура та правосвідомість європейських учасників ринку настільки висока, що беззаперечно діє така формула: коли підприємства 
використовують гармонізовані стандарти, то вони автоматично користуються «презумпцією відповідності» цим вимогам та обов'язковим вимогам, викладеним у відповідному європейському законодавстві. Це означає, що вони можуть продавати свої продукти чи послуги на єдиному європейському ринку, отримуючи доступ до 600 мільйонів споживачів в 34 країнах. Одночасно споживачам гарантуються безпечні та екологічно чисті продукти та послуги через правильне застосування EN.

Наш шлях у Європу та до іï ринків передбачає необхідність дослідити процедури введення нових чи оновлення діючих стандартів. Основою (джерелом) початку такого процесу є так званий мандат. Мандат є механізмом, за допомогою якого СК та секретаріат САВТ вимагають від європейських організацій стандартизації розробляти та впроваджувати EN для підтримки європейської політики та законодавства. Цей механізм передбачає здійснення певних процедур:

1) ЄК надсилає попередній проект мандату до організації;

2) текст розглядається відповідним технічним органом/органами;

3) подаються зауваження до ЄК, включаючи пропозиції щодо конкретних змін у тексті (з пояснювальними примітками);

4) проект мандату представляється Постійному комітету, відповідальному за виконання процедури, описаної в Директиві 98/34/СС, яка забезпечує проведення широкої консультації 3 національними органами влади та національними органами стандартизації в державах-членах $\mathrm{CC}$;

5) погоджений мандат офіційно подається до організації та знову розглядається відповідним технічним органом або органами;

6) технічна комісія (орган) організації приймає рішення про прийняття мандату з обмеженнями чи без, беручи до уваги думки компетентних органів;

7) організація інформує СК про задоволення мандату.

Після цього проводиться робота 3 поширення вимог стандартизації відповідно до прийнятого мандату та здійснюється контроль за впровадженням цих вимог у національне законодавство. 
В України покищо не виникає потреби у долученні до європейських процедур мандатів, але вже робляться кроки назустріч європейському ринку, а тому маємо бути готовими до виконання усталених процедур, що застосовуються в країнах $\mathrm{CC}$.

У рамках держави застосовуються тільки національні стандарти. Міжнародний або регіональний стандарт не обов'язковий до включення в національну збірку стандартів. Кожна країна вирішує питання про прийняття міжнародного чи регіонального стандарту як національного. Водночас Законом України «Про стандартизацію» (ст. 17) передбачається, що міжнародні, регіональні та інші наднаціональні стандарти мають бути основою для розробки (переробки) національних. Якщо Україна не дотримується цього правила, то національний орган стандартизації має надавати письмове пояснення.

Розрізняють стандарти обов'язкового і добровільного використання (ч. 2 ст. 23 Закону України «Про стандартизацію»). Стандарти обов'язкового використання містять обов'язкові вимоги, регламентовані законом. Від дотримання підприємцями обов'язкових вимог стандартів залежать здоров'я i безпека споживачів, безпека праці в процесі виробництва, охорона навколишнього середовища, сумісність та взаємозамінність продукції. Крім того, вимоги обов'язкових стандартів захищають споживачів від продукції низької якості в тих випадках, коли на ринку немає конкуруючих пропозицій. Обов'язкові вимоги стандартів підлягають безумовному виконанню органами виконавчої державної влади, всіма підприємствами, їх об'єднаннями, установами, організаціями та громадянами - суб'єктами підприємницької діяльності, на діяльність яких поширюється дія стандартів.

До обов'язкових вимог належать: вимоги, які забезпечують безпеку продукції для життя, здоров'я та майна громадян, охорону навколишнього середовища; вимоги, які забезпечують сумісність і взаємозамінність продукції, i вимоги до методів вимірювання цих показників; вимоги техніки безпеки та гігієни праці відповідно до діючих санітарних норм і правил; метрологічні норми, 
правила, вимоги та положення, які забезпечують достовірність і єдність вимірювань; положення, які забезпечують технічну єдність під час розроблення, виготовлення, експлуатації продукції. Ці норми на сьогодні прямо не передбачені у законодавстві, але через принципи, що закріплюються у ст. 4 Закону України «Про стандартизацію», вважаємо за необхідне говорити про їх обов'язковість.

Стандарти добровільного використання містять вимоги рекомендаційного характеру (ч. 2 ст. 23 Закону України «Про стандартизацію»). На нашу думку, заява про дотримання виробником продукції стандартів добровільного використання застосовується для досягнення таких цілей: посилення довіри до якості продукції та розширення ринку збуту; усунення конкуренції з боку виробників, які використовують стандарти 3 більш низькими вимогами; підтримки іміджу фірми, забезпечення реклами і збільшення обсягу продажів. Якщо виробник вирішив випускати продукцію (надавати послуги) відповідно до вимог стандарту добровільного використання, то після декларованої заяви стандарти добровільного використання стають обов'язковими до застосування. Подібна позиція існувала навіть «в радянські часи» [284, с. 203]. Вимога застосовувати стандарти добровільного використання може бути обумовлена договором. Відхилення від обумовлених договором вимог стандартів ведуть до розриву договірних відносин, виникнення зобов'язань, втрати репутації на ринку тощо, про що буде йтися нижче. Таким чином, рекомендовані вимоги стандартів підлягають безумовному виконанню в таких випадках: якщо виробник (постачальник) продукції зробив заяву про відповідність продукції цим стандартам; якщо ці вимоги включено до договорів на розробку, виготовлення $\mathrm{i}$ поставку продукції; якщо це передбачено окремими нормативно-правовими актами України.

Повертаючись до питання забезпечення відповідності продукції (послуг) вимогам, то, задовольняючи вимогу про вибір законних способів ведення господарської діяльності, виробникам України дозволяється приймати інші рішення, крім застосування стандартів 3 переліку національних стандартів. 
Зазначені посилання та переліки формуються на основі відповідних посилань і переліків, опублікованих в «Офіційному віснику Європейського Союзу» [10]. У разі якщо актами законодавства $\mathrm{CC}$, передбачене надання презумпції відповідності продукції, пов'язаних з нею процесів або методів виробництва чи інших об'єктів, що відповідають іншим, крім стандартів 3 переліку національних стандартів, нормативним документам і технічним специфікаціям (їх положенням), та за умови, що посилання на такі нормативні документи і технічні специфікації (ix положення) опубліковані в «Офіційному віснику Європейського Союзу», відповідні центральні органи виконавчої влади розміщують на своїх офіційних веб-сайтах переліки відповідних посилань [139; 158; 78].

Як зазначено вище, європейці набагато простіше розуміють і ставлять «грань» між добровільністю та обов'язковістю вимог стандартизації. Для них усі вимоги законодавства у сфері стандартизації - обов'язкові, а вимоги, що містяться поза законодавством, - добровільні.

У теорії серед існуючих стандартів виділяють також попередній стандарт як тимчасовий документ, який приймається органом зі стандартизації і доводиться до широкого кола потенційних споживачів [206, с. 16]. Інформація, отримана в процесі використання попереднього стандарту, та відгуки про цей документ слугують базою для вирішення питання про доцільність прийняття стандарту. У сферах, де об'єкти стандартизації швидко змінюються, або за потреби накопичити досвід використання виробу чи нормативно-технічного документа 3 метою випробувати положення стандарту чи обгрунтувати вибір із можливих запропонованих альтернатив певних положень розробляють пробні стандарти. Їх приймають тимчасовим органом стандартизації й доводять до широкого кола користувачів з метою накопичення потрібного досвіду в процесі застосування нормативно-технічного документа, і вони можуть бути використані як база стандарту. Пробні стандарти можуть мати менший рівень консенсусу, зокрема його можна досягнути на рівні ТС зі стандартизації чи навіть на рівні його робочої групи. Пробні стандарти розробляють на проекти міжнародних та 
регіональних стандартів. Як пробні стандарти можна застосовувати нові документи ISO: PAS (загальнодоступні ТУ), TS (ТУ) та ITA (галузеві технічні угоди).

У практиці ISO, розрізняють такі види стандартів [154]:

За обсягом вимог:

1. Основоположний стандарт - нормативний документ, який містить загальні або керівні положення для певної галузі. Зазвичай використовується як стандарт або як методичний документ, на основі якого можуть розроблятися інші стандарти.

2. Термінологічний стандарт, в якому об'єктом стандартизації $є$ терміни. Такий стандарт містить визначення (тлумачення) терміна, приклади його застосування тощо.

За сферою застосування:

1. Стандарт на методи випробувань, який встановлює методики, правила, процедури різних випробувань і пов'язаних з ними дій (наприклад, відбір проб або зразка).

2. Стандарт на продукцію, що містить вимоги до продукції, які забезпечують відповідність продукції ії призначенням, може бути повним або неповним.

За повнотою викладених вимог:

1. Неповний стандарт встановлює вимоги до продукції (тільки до параметрів якості, до правил постачання тощо).

2. Повний стандарт встановлює не тільки зазначені вимоги, а й правила відбору проб, проведення випробувань, упаковки, етикетування, зберігання.

За функціональністю:

1. Стандарт на процес, стандарт на послугу - це нормативні документи, в яких об'єктом стандартизації виступають відповідно процес (наприклад технологія виробництва), послуга (автосервіс, банківське обслуговування).

2. Стандарт на сумісність, який встановлює вимоги, що стосуються сумісності продукту в цілому, а також його окремих частин (деталей, вузлів). 
Такий стандарт може бути розроблений на систему в цілому, наприклад: на систему очищення повітря, сигналізаційну систему.

Залежно від об’єкта стандартизації, положень, які містить документ, та процедур надання йому чинності, в Україні розрізняють такі нормативно-технічні документи: кодекси усталеної практики, ТУ, державні класифікатори.

Кодекси усталеної практики розробляють на устаткування, конструкції, технічні системи, вироби того самого чи подібного функціонального призначення, але які різняться конструктивним виконанням чи принципом дії i для яких аспекти проектування, виготовлення чи встановлення (монтажу), експлуатування чи утилізування $€$ визначальними для їхнього безпечного функціонування (житлові, промислові будівлі та споруди, котли, посудини, що працюють під тиском, компресорне устаткування тощо) (п. 4 ч. 1 ст. 1 Закону України «Про стандартизацію»). У кодексах усталеної практики також подають правила i методи розв'язання завдань щодо організації та координації робіт зі стандартизації й метрології, а також реалізації певних вимог технічних регламентів чи стандартів тощо. До кодексів усталеної практики належать документи, що мають різні назви: настанови, правила, зведення правил. Настанова, зведення правил (правила) - це нормативно-технічний документ, що рекомендує практичні прийоми чи методи проектування, виготовлення монтажу, експлуатації або утилізації обладнання, конструкцій чи виробів (п. 3.2 Наказу Мінпаливенерго України «Про затвердження та надання чинності нормативному документу Мінпаливенерго України «Правила розроблення нормативних документів» від 01.03.2006 р. № 56, ДСТУ 1.1:2015). Настанова може бути стандартом або іншим незалежним від стандарту документом.

До цих документів слід відносити і технічні регламенти, оскільки за визначенням вони $\epsilon$ нормативно-правовими актами, в яких визначено характеристики продукції або пов'язані з ними процеси та методи виробництва, включаючи відповідні процедурні положення, додержання яких $є$ обов'язковим (ст. 1 Закону України «Про технічні регламенти та оцінку відповідності»). 
Технічний регламент може також включати або виключно стосуватися вимог до термінології, позначень, пакування, маркування чи етикетування в тій мірі, в якій вони застосовуються до продукції, процесу або методу виробництва.

Якщо звернутися до міжнародного термінологічного стандарту ISO/IEC Guide 2:1996 (Standardization and related activities - General vocabulary), до його оновленої редакції ISO/IEC Guide 2:2004 та до європейського термінологічного стандарту EN 45020:2006, то можна отримати такі визначення:

1) регламент - документ, що містить обов'язкові законодавчі правила, що приймається повноважним органом (варто зазначити що у розумінні ст. 288 Договору про заснування $Є \mathrm{C}$ регламент є нормативно-правовим актом $€ \mathrm{C}$, що має бути загальнодоступним, повністю обов'язковим та безпосередньо застосовуватися в усіх державах-членах. Це визначення за своєю сутністю не суперечить EN 45020:2006);

2) технічний регламент - положення, яке містить технічні вимоги безпосередньо або шляхом включення посилання на вміст стандарту, технічної специфікації або кодексу практики (технічний регламент може бути доповнений технічними настановами та рекомендаціями, які викладаються через певні засоби 3 дотриманням вимог регламенту, а тому вважаються такими, що задовольняють положення).

3 цього випливає, що регламент є юридично обов'язковим актом, ухваленим компетентними органами $\mathrm{CC}$, що має загальне застосування та юридичну силу в усій своїй цілісності і прямо застосовується у всіх державах - членах СС. Одночасно регламент, що доповнений технічною настановою, що визначає способи дотримання вимог, називається технічним регламентом. Тут можна говорити, що первинною метою є створення норми права, а вторинною доповнення ії̈ технічними нормами.

Разом $з$ тим не слід забувати про безпекову складову стандартизації, коли говоримо про технічні регламенти, оскільки метою прийняття технічних регламентів є захист життя та здоров'я людей, тварин і рослин, охорона довкілля 
та природних ресурсів, забезпечення енергоефективності, захист майна, забезпечення національної безпеки та запобігання підприємницькій практиці, що вводить споживача (користувача) в оману (ч. 1 ст. 9 Закону України «Про технічні регламенти та оцінку відповідності»). Законами України, у тому числі технічними регламентами, можуть бути визначені інші цілі прийняття технічних регламентів. На нашу думку, виключення з цілей технічного регламенту економічної складової (наприклад, виготовлення товарів чи послуг відповідно до напряму діяльності, отримання прибутку, розвиток підприємництва в Україні тощо) призводить до тяжіння над суб'єктами господарської діяльності відповідальності за недотримання вимог стандартизації, але не стимулює їх до добровільного застосування таких вимог задля отримання економічних вигод.

Технічні регламенти розробляються, приймаються та застосовуються на основі принципів, установлених Угодою СОТ про технічні бар'єри у торгівлі, що є додатком до Марракеської угоди про заснування СОТ 1994 року, (ч. 3 ст. 9 Закону України «Про технічні регламенти та оцінку відповідності») та на основі:

- міжнародних стандартів, якщо вони вже прийняті або перебувають на завершальній стадії розроблення, чи їх відповідних частин, за винятком випадків, коли такі міжнародні стандарти чи їх відповідні частини є неефективними або невідповідними засобами для досягнення визначених цілей прийняття технічних регламентів, зокрема, внаслідок суттєвих кліматичних чи географічних чинників або суттєвих технологічних проблем;

- регіональних стандартів, національних стандартів України чи інших держав, актів законодавства ЄС, інших економічних об'єднань або інших держав чи відповідних частин таких стандартів і актів законодавства.

Технічні регламенти затверджуються законами, актами Кабінету Міністрів України та центральних органів виконавчої влади. Технічні регламенти, якими передбачене застосування процедур оцінки відповідності, затверджуються законами або актами Кабінету Міністрів України. Нормативно-правовий акт, що має визначені законодавством ознаки технічного регламенту, вважається 
технічним регламентом незалежно від використання в назві такого акта слів «технічний регламент». Визначення в різних технічних регламентах спеціальних вимог, що спрямовані на запобігання чи усунення одного й того самого виду ризику стосовно одного й того самого виду продукції, забороняється (ч. 5 ст. 9 Закону України «Про технічні регламенти та оцінку відповідності»).

У разі якщо технічний регламент розробляється на основі акта законодавства $\mathrm{EC}$, зміст, форма та структура такого технічного регламенту повинні максимально повно і точно відповідати змісту, формі та структурі відповідного акта законодавства $С С$ з урахуванням можливості врегулювання конкретних суспільних відносин нормами актів законодавства України (ч. 3 ст. 9 Закону України «Про технічні регламенти та оцінку відповідності»). Кабінет Міністрів України визначає правила розроблення проектів технічних регламентів на основі актів законодавства ЄC [188]. У разі потреби разом 3 технічними регламентами, крім тих, що затверджені законами, затверджуються плани заходів з їх впровадження [161; 145]. Плани заходів із впровадження технічних регламентів, затверджених законами, у разі потреби затверджуються Кабінетом Міністрів України [189].

Відповідність введеної в оборот, наданої на ринку або введеної в експлуатацію в Україні продукції вимогам усіх чинних технічних регламентів, які застосовуються до такої продукції, є обов’язковою (ч. 1 ст. 11 Закону України «Про технічні регламенти та оцінку відповідності»). Тобто на статичній стадії стандартизації закріплюється обов'язковість вимог. Відповідність продукції вимогам технічних регламентів може бути забезпечена шляхом застосування національних стандартів та/або технічних специфікацій, посилання на які містяться у відповідних технічних регламентах. Наприклад, у технічному регламенті зазначається, чи відповідність продукції таким національним стандартам та/або технічним специфікаціям є єдиним способом, чи одним із способів задоволення відповідних вимог технічного регламенту. Технічним регламентом може бути передбачено, що відповідність продукції, пов'язаних з нею процесів або методів виробництва чи інших об'єктів національним стандартам, перелік яких 
затверджений відповідним центральним органом виконавчої влади, або їх частинам надає презумпцію відповідності такої продукції, пов'язаних з нею процесів або методів виробництва чи інших об'єктів вимогам зазначеного технічного регламенту, які охоплюються цими стандартами або їх частинами та визначені в технічному регламенті. Якщо стандарт 3 переліку національних стандартів не повною мірою задовольняє вимоги, на охоплення яких спрямований цей стандарт та які визначені у відповідному технічному регламенті, відповідний центральний орган виконавчої влади за результатами консультацій 3 національним органом стандартизації включає такий стандарт до переліку національних стандартів, не включає його, включає його з обмеженням, залишає його в переліку, залишає його в переліку з обмеженням або виключає його з переліку.

У переліку національних стандартів для стандартів, що включені до нього або залишені в ньому з обмеженням, зазначається зміст обмежень у наданні презумпції відповідності вимогам відповідного технічного регламенту внаслідок застосування зазначених стандартів чи їх окремих положень. У разі потреби відповідні центральні органи виконавчої влади звертаються до національного органу стандартизації щодо необхідності забезпечення перевірки та перегляду тих стандартів, які містяться в переліку національних стандартів i застосування яких не надає презумпції відповідності вимогам технічного регламенту або надає іiі лише частково [128; 134]. У разі включення до переліку національних стандартів нового стандарту на заміну стандарту, що раніше був включений до переліку, зазначається дата припинення надання презумпції відповідності внаслідок застосування заміненого стандарту. При цьому може бути передбачено, що до настання цієї дати презумпція відповідності надається внаслідок застосування як нового, так і заміненого національного стандарту. Така процедура, на нашу думку, надає можливість забезпечити баланс мети стандартизації та мети господарської діяльності.

У разі якщо технічний регламент було розроблено на основі акта законодавства $\mathrm{CC}$, яким передбачене надання презумпції відповідності продукції, пов'язаних 3 нею процесів або методів виробництва чи інших об'єктів, що 
відповідають гармонізованим $\mathrm{EN}$, до переліку національних стандартів включаються лише національні стандарти, що $\epsilon$ ідентичними відповідним гармонізованим EN. При цьому в переліку національних стандартів враховуються відомості про періоди надання та обмеження у наданні презумпції відповідності внаслідок застосування відповідних гармонізованих EN.

Переліки національних стандартів формуються згідно 3 методичними рекомендаціями, затвердженими центральним органом виконавчої влади, що забезпечує формування державної політики у сфері технічного регулювання. Національний орган стандартизації за запитами відповідних центральних органів виконавчої влади надає їм інформаційну та методологічну допомогу стосовно формування переліків національних стандартів. Перелік національних стандартів затверджується вперше до набрання чинності відповідним технічним регламентом, а після цього оновлюється в разі потреби шляхом його затвердження. Відповідні центральні органи виконавчої влади розміщують затверджені ними переліки національних стандартів на своїх офіційних веб-сайтах не пізніше п'яти робочих днів 3 дня їх затвердження. Так, на офіційних сайтах Мінекономрозвитку та ДП «Укрметртестстандарт» вже розміщуються такі посилання [158]. Конкретні умови надання презумпції відповідності продукції, пов’язаних з нею процесів або методів виробництва чи інших об'єктів визначаються технічними регламентами, якими передбачене іiі надання. Наприклад, презумпція відповідності засобів вимірювальної техніки застосовується виробником таким чином: можна використовувати будь-яке технічне рішення, що відповідає суттєвим вимогам, установленим у додатку 1 Технічного регламенту засобів вимірювальної техніки [190], та вимогам, установленим у відповідних додатках 3-12. Тобто йдеться про наявність добровільності у варіантах при виборі, але обов'язковості - у необхідності його зробити.

Зміст технічних регламентів, як правило, складається з:

1) норм права стосовно об'єкта, визначення прав та обов'язків суб'єктів господарської діяльності щодо цього об'єкта: загальні засади проведення процедур 
оцінки відповідності та здійснення державного ринкового нагляду;

2) вимог технічного чи технологічного характеру, що мають виконуватися, як раніше йшлося, в обов'язковому порядку, стосовно об'єкта. До цих вимог можуть відноситися окремі вимоги або частини стандартів. Так само може відбуватися відсилання до конкретного стандарту чи надаватися їх перелік.

Як бачимо, у змісті технічного регламенту йдеться про нормативну та технічну складову, а тому справедливо буде віднести його до нормативнотехнічних документів. Одночасно він $є$ кодексом усталеної практики, оскільки засновується на існуючому вже досвіді.

Крім стандартів та інших нормативно-технічних документів існують ще ТУ, що встановлюють технічні вимоги до продукції, послуги, процесу [167, с. 18]. ТУ - нормативно-технічний документ, що встановлює вимоги до продукції, призначеної для самостійного постачання, до виконання процесів чи надання послуг замовникові, і регулює відносини між виробником (постачальником) i споживачем (користувачем). Їх затверджують на продукцію, яка перебуває в стадії освоєння і виробляється невеликими партіями. ТУ розробляються на один чи декілька конкретних виробів, матеріалів, речовин, послугу чи групу послуг. Підприємства використовують ТУ незалежно від форми власності та підлеглості, громадяни - суб'єкти підприємницької діяльності - за договірними зобов'язаннями або ліцензіями на право виготовлення та реалізацію продукції або надання послуг [239, с. 178].

ТУ посідають особливе місце в комплексі технічної документації на товари та послуги, адже вони є основним документом на постачання продукції і надання послуг. У ТУ встановлюються певні вимоги до конкретної продукції або послуги, в якій визначені показники стандартів. Ці показники мають забезпечувати повну характеристику споживних властивостей товарів та послуг і можливість їх визначення та контролю.

Державні класифікатори - це нормативно-технічні документи, в яких об'єкти стандартизації класифікуються за суттєвими ознаками й поділяються на 
класи, підкласи i групи. Державні класифікатори України гармонізовані 3 Міжнародною класифікацією ISO i мають гармонізовану систему опису та кодування об’єктів. Так, в Україні діють 19 Державних класифікаторів (зокрема, ДК-001-94 «Класифікатор форм власності», ДК-003-95 «Класифікатор професій», ДК-006-96 «Класифікатор валют», ДК-009-96 «Класифікатор видів економічної діяльності», ДК-012-97 «Класифікатор послуг зовнішньоекономічної діяльності», ДК-016-97 «Державний класифікатор продукції та послуг» та інші).

Нормативно-технічні документи громадських організацій (наукових, науково-технічних та інженерних товариств і спілок) розробляють тоді, коли є потреба поширення та впровадження систематизованих, узагальнених результатів фундаментальних і прикладних досліджень чи практичного досвіду, одержаних у певних галузях науки чи сферах професійних інтересів [206, с. 15; 193, с. 45]. Стандарти громадських організацій може застосовувати будь-який суб'єкт господарювання за умови отримання згоди на їх застосування від власника зазначених нормативно-технічних документів на договірних чи інших засадах.

Основоположний словник стандартизації ISO, а також ЄC надає можливість виділити чотири види документів у цій сфері:

1) стандарти - документи, розроблені на основі консенсусу та затверджені визнаним органом, який забезпечує їх загальне і багаторазове використання, що містять правила, керівні принципи або характеристики різних видів діяльності або ïx результатів та спрямовані на досягнення оптимального ступеня впорядкованості в даному контексті;

2) технічні специфікації - документи, які передбачають технічні вимоги, що повинні бути виконані за допомогою продукту, процесу чи послуги (технічна специфікація може бути стандартом, частиною стандарту або незалежною від стандарту);

3) кодекси практики (процесуальні кодекси) - документи, які рекомендують практику або процедуру проектування, виготовлення, монтажу, технічного обслуговування або використання обладнання, конструкцій або виробів (кодекс 
практики може бути стандартом, частиною стандарту або незалежним від стандарту);

4) правила (акти регулювання) - документи, що містять обов’язкові законодавчі правила, що приймаються відповідним органом. Різновидом цих документів $є$ технічний регламент, що може містити технічні вимоги або безпосередньо, або шляхом посилання чи включення змісту стандарту, технічної специфікації або кодексу практики в текст.

На основі викладеного вище можна стверджувати, що акти регулювання у сфері стандартизаиії є документами, щุо містять правила, керівні принципи або характеристики різних видів діяльності або їх результатів та спрямовані на досягнення мети такого регулювання. Частина таких документів входить до законодавства України в обов'язковому порядку та набуває ознак нормативноправових актів, виконання яких забезпечується державою. Інша частина існує та застосовується на основі принципів саморегулювання господарської діяльності (детально буде йтися нижче).

\section{Висновки до розділу 2}

Стандартизація як багатоаспектне явище має багато проявів i може розумітися в широкому та вузькому розумінні, а також як метод та засіб регулювання певної галузі. За легальним визначенням стандартизація як діяльність полягає у встановленні положень для загального і багаторазового застосування щодо наявних чи можливих завдань 3 метою досягнення оптимального ступеня впорядкування у певній сфері.

На міжнародному рівні важливими перевагами стандартизації називають поліпшення придатності продукції, процесів і послуг за їх прямим призначенням, запобігання створенню бар'єрів в торгівлі та сприяння технічному 
співробітництву. Це той орієнтир, червона нитка, що пронизує усі подальші розробки не лише в ISO, а й у документах організацій, що прямо не займаються стандартизацією, але використовують іiі досягнення (ГАТТ, СОТ як iі правонаступниці, ЄС та інших наднаціональних організацій).

На сьогодні слід визначати стандартизацію як діяльність, що полягає в установленні ma застосуванні положень для загального та неодноразового використання щодо наявних чи потенційних завдань і спрямована на досягнення оптимального ступеня впорядкованості в певній сфері суспільного життя для забезпечення своєї мети.

Метою стандартизації $\epsilon$ встановлення положень, що забезпечують відповідність об’єктів стандартизації своєму призначенню та їх безпечність для життя, здоров'я, майна людей, збереження тварин, рослин і охорони природного довкілля, що створюють умови для раціонального використання всіх видів національних ресурсів, сприяють усуненню технічних бар'єрів у торгівлі та підвищенню конкурентоспроможності продукції до рівня розвитку науки, техніки i технологій та розвитку міжнародного економічного, наукового і технічного співробітництва.

У сучасному розумінні стандартизації йдеться про дві складові: технічну та безпекову. Технічна складова $є$ класичною, такою що історично складалася, i визначає технічні вимоги. Безпекова - виникла у середині XX ст., коли у суспільство усвідомило, що підвищення рівня життя, яке є основною ознакою науково-технічного прогресу, не повинно вступати в протиріччя із суспільною необхідністю у збереженні довкілля та зміцненні здоров'я людини як основного показника у визначенні рівня розвитку суспільства.

Для оптимального досягнення мети стандартизація має грунтуватися на принципах, які в законодавстві України необхідно уніфікувати та викласти у такому вигляді: 1. Добровільне застосування стандартів та забезпечення умов для їх однакового застосування. 2. Застосування міжнародного стандарту як основи для розроблення національного стандарту. 3. Збалансованість інтересів сторін, що 
розробляють, виготовляють i споживають продукцію. 4. Динамічність і випереджувальний розвиток стандарту. 5. Ефективність стандартизації. 6. Принцип гармонізації. 7. Чіткість формулювань положень стандарту.

Діяльність зі стандартизації здійснюється на різних рівнях. Рівні стандартизації розрізняються залежно від того, учасники якого географічного, економічного, політичного регіону світу будуть використовувати стандарт. На відміну від законодавчого поділу (на два рівні) пропонуємо застосовувати поділ на три рівні: міжнародний, регіональний та національний.

Стандартизація проявляється як у статиці, так і в динаміці. У статичному стані стандартизація закріплює положення, стандарти, регламенти та інші вимоги. У динаміці стандартизація працює у вигляді порівняння документально закріплених вимог та існуючих об’єктів стандартизації, а також є основою для інших видів діяльності, що складають у сукупності систему стандартизації. До них відносяться технічне регулювання та оцінка відповідності. Підтвердження відповідності за допомогою процедури оцінки часто $\epsilon$ необов'язковим (додатковим) етапом стандартизації, що може завершити процес правореалізації або створити передумови для настання як позитивних, так і негативних наслідків для суб'єктів господарської діяльності.

Аналіз співвідношення стандартизація-технічне регулювання надає можливість дійти висновку, що стандартизація походить від соціального регулювання, породжує норми технічного, організаційного чи іншого впорядковуючого характеру, які можуть переходити (перетворюватися) в норми права. Водночас технічне регулювання є похідним із правового регулювання (частини соціального регулювання) та породжує технічні регламенти, що $є$ нормативно-правовими актами - частиною національного законодавства України, у тому числі господарського. Саме тому технічне регулювання $є$ частиною стандартизації, а стандартизація є основою для технічного регулювання.

У процесі стандартизації здійснюється встановлення вимог для забезпечення якості продукції, робіт і послуг. Відповідно, основними 
результатами діяльності в галузі стандартизації повинні бути підвищення якості продукту (послуги), усунення технічних бар'єрів у міжнародному товарообміні, сприяння співпраці в різних сферах. Результатом діяльності у сфері стандартизації є створення актів регулювання, на підставі яких здійснюється господарська діяльність.

При використанні стандартизації у регулюванні господарської діяльності йдеться також про використання нормативно-технічних документів як основних актів такого регулювання. Інколи навіть можна прослідкувати переважність технічних норм перед юридичними у разі застосування принципу добровільності вимог стандартизації. Превага юридичних норм перед технічними прослідковується тоді, коли принцип добровільності застосування стандартів може бути усунений, якщо того вимагає технічний регламент, що має форму закону. У такому разі говоримо про принцип чітко регламентованого державного обов'язкового регулювання господарської діяльності.

Нормативно-технічний документ - це офіційний документ, що прийнятий уповноваженим на це суб'єктом нормотворення у визначеній законом формі та порядку, який встановлює правила, загальні принципи та характеристики різного виду діяльності або іiї результатів для неозначеного кола осіб і розрахований на неодноразове застосування. Нормативно-технічні документи розробляються на об'єкти стандартизації, які є обов'язковими для використання в окремих галузях діяльності в установленому порядку і затверджуються компетентними органами.

До нормативно-технічних документів належать стандарти, кодекси усталеної практики (настанови, правила, зведення правил), ТУ, регламенти, державні класифікатори, технічні регламенти тощо.

Основоположний словник стандартизації ISO, а також ЄC надає можливість виділити чотири види документів у цій сфері: 1) стандарти; 2) технічні специфікації; 3) кодекси практики (процесуальні кодекси); 4) правила (акти регулювання). Різновидом цих документів $є$ технічний регламент, що може 
містити технічні вимоги або безпосередньо, або шляхом посилання чи включення змісту стандарту, технічної специфікації або кодексу практики в текст.

Актами регулювання у сфері стандартизації $\epsilon$ документи, що містять правила, керівні принципи або характеристики різних видів діяльності або їх результатів та спрямовані на досягнення мети такого регулювання.

Ефективність стандартизації як засобу регулювання господарської діяльності може бути забезпечена 3 допомогою регламентації усіх процесів (у тому числі управлінських) на первинному етапі виробництва товарів (надання послуг) для стабільної роботи суб'єктів господарювання та забезпечення вимог щодо безпеки для життя і здоров’я людини та охорони довкілля. 


\section{РОЗДІЛ 3}

\section{ОСОБЛИВОСТІ ПРАВОВОГО РЕЖИМУ СТАНДАРТИЗАЦЇ̈ ТА ПРАВОВОГО СТАТУСУ П̈Ї СУБ'ЄКТІВ}

\section{1 Особливості стандартизації як засобу впливу на господарську діяльність}

Увесь масив господарського законодавства спрямований на забезпечення здійснення господарської діяльності. Поняття господарської діяльності знаходимо в різних нормативно-правових актах, але керуємося визначенням Господарського кодексу України, де під господарською діяльністю розуміється діяльність суб'єктів господарювання у сфері суспільного виробництва, спрямована на виготовлення та реалізацію продукції, виконання робіт чи надання послуг вартісного характеру, що мають цінову визначеність. У цьому визначенні традиційно виділяють кілька ознак господарської діяльності:

1) сфера здійснення - суспільне виробництво (іншими словами це і $є$ господарська сфера);

2) зміст - виробництво та реалізація продукції, виконання робіт, надання послуг відбувається не для власних потреб виробника, а для задоволення потреб інших осіб - споживачів у широкому розумінні (громадян як кінцевих споживачів, суб'єктів господарювання та різноманітних організацій, що використовують зазначені блага як первинний ресурс для задоволення своїх господарських чи інших потреб, а також для виробництва товарів і послуг);

3) передача зазначених благ іншим особам на платній основі, тобто їх функціонування у формі товару;

4) професійні засади здійснення такої діяльності;

5) спеціальний суб’єкт, який повинен зазвичай мати статус суб’'єкта господарювання 
(набуття цього статусу завершується, як правило, державною реєстрацією в загальному та/або спеціальному порядку);

6) поєднання приватних інтересів виробника (в одержанні прибутку чи інших вигод/переваг від господарської діяльності) та публічних інтересів (суспільства в особі широкого кола споживачів - в отриманні певних благ; держави та/чи територіальної громади - в отриманні прибутків та інших обов'язкових платежів від суб'єктів господарювання; територіальної громади;

7) значний рівень державного (у тому числі нормативно-правового) регулювання, що зумовлено попередньою ознакою (приватні інтереси суб'єкта господарювання - виробника задовольняються за рахунок суспільних інтересів необхідності задоволення потреб споживачів у певних видах товарів, робіт, послуг).

3 цих ознак господарської діяльності вбачається намагання законодавця забезпечити збалансованість інтересів суб'єктів приватного та публічного права. Зокрема, передбачається чітке окреслення меж (сфер та умов) існування та забезпечення суб'єкта господарської діяльності у поєднанні зі свободою вибору варіантів поведінки (дій чи бездіяльності) цього суб’єкта 3 одночасним врахуванням інтересів інших суб'єктів та непорушенням їх прав.

Про це йшлося ще навіть у «радянські часи», коли держава збалансовувала інтереси суспільства та карала суб'єктів господарської діяльності, що вдавалися до невиконання вимог нормативно-технічних документів та застосовували інші форми несумлінної поведінки $з$ метою зменшення своїх видатків та отримання найбільших прибутків [111, с. 91].

Учені зазвичай дають таке доктринальне визначення: господарська діяльність - це така суспільно-корисна діяльність суб'єктів господарювання щодо виробництва продукції, виконання робіт, надання послуг з метою їх реалізації за плату (як товару), що грунтується на поєднанні приватних і публічних інтересів, здійснюється професійно та зазнає значного регулювання з метою соціального спрямування економіки [28, с. $8-11 ; 70$, с. $121 ; 84$, с. $43 ; 273$, с. 6-7]. Будь-яка господарська діяльність здійснюється на певних засадах, що враховують, з одного 
боку, ринкову орієнтацію національної економіки і, відповідно, передбачають значну свободу для суб'єктів такої діяльності (насамперед підприємців), а 3 іншого - соціальне спрямування господарської сфери, що зумовлює встановлення певних обмежень для суб’єктів господарювання з метою врахування публічних інтересів (суспільства, держави, територіальної громади/громад, типових приватних інтересів громадян та організацій) у дотриманні встановленого державою правового господарського порядку, що передбачає додержання суб'єктами господарювання різноманітних вимог щодо: якості продукції, робіт, послуг, їх безпечності для життя і здоров'я споживачів; екологічної безпеки виробництва; добросовісної поведінки у сфері економічної конкуренції; цивілізованого використання найманої праці (тобто відповідно до вимог трудового законодавства). Про необхідність раціонального втручання держави у господарську діяльність суб'єктів у працях науковців вже йшлося неодноразово [12; 54; 126; 201], але «універсального рецепту» ще досі не запропоновано.

На сьогодні гостро постала проблема оптимального співвідношення господарської діяльності та забезпечення здорового довкілля. Баланс цих складових досягається з допомогою правового впливу. Форми та методи даного впливу змінюються залежно від суспільних потреб [99, с. 42; 104, с. 72-73; 107, с. $94 ; 151$, с. $74 ; 163$, с. $241 ; 165$, с. $7 ; 254$, с. 29 ]. Забезпечити це може своєчасна підготовка, розробка та впровадження системи стандартизації, що має врегулювати господарську діяльність, забезпечити виконання господарюючими суб'єктами вимог нормативно-технічних документів та вдосконалити способи та методи виробництва.

В юридичній літературі проблема правового впливу та правового регулювання не $є$ новою [110, с. 5]. У науці сформувалися напрями, які дають можливість дослідити право як ефективний засіб соціального регулювання. Однією 3 основних функцій держави $€$ організація життя в суспільстві 3 метою забезпечення нормальних умов життєдіяльності. Держава завжди втручалася у діяльність господарюючих суб'єктів, виступаючи у ролі регулятора ринку та 
забезпечуючи його стабільну роботу $[24$, с. $4-5 ; 196$, с. $3-4 ; 219$, с. 14 ; 237, с. 26 ; 238 , с. 12]. Саме тому зазвичай говорять про регуляторну політику держави як першооснову стабільного та конкурентного ринку. Активний розвиток ринку сприяє зростанню приватного сектора економіки, який починає надавати нові послуги чи випускати нові товари $[7$, с. $14 ; 55$, с. $8,10,14,18 ; 77$, с. $8 ; 165$, с. 9-10; 262 , с. 87, 90], що, у свою чергу, вимагає особливої уваги до стандартизації продукції та послуг державою.

Деякі вчені висловлюють думку про можливість саморегулювання у сфері господарської діяльності [55, с. 49, 53; 182, с. 176; 215, с. 113]. Схожу позицію, засновану на неякісності правового регулювання господарської діяльності та проблемах моральності та справедливості у нормативно-правових актах, висловлює О.Х. Юлдашев $[277$, с. 50]. Погоджуючись 3 можливістю саморегулювання в господарській діяльності, В. В. Добровольська наголошує, що існує реальна можливість перетворення господарюючого суб'єкта в закриту монополію (особливо при регулюванні відносин щодо використання, охорони та відновлення природних ресурсів) [55, с. 53, 55, 56]. На нашу думку, саморегулювання господарської діяльності з допомогою стандартизації допускається. Особливо суттєвим воно $є$ у разі застосування добровільних вимог, дотримання яких контролюється не лише правом, а й іншими соціальними регуляторами.

Правове регулювання в суспільстві здійснюється за допомогою певних механізмів. У теорії права під механізмом правового регулювання слід розуміти різні елементи правової системи, які чинять регулятивний вплив на суспільство. Це певна, взята у єдності, сукупність правових засобів, способів і форм, за допомогою яких нормативність права забезпечує впорядкування суспільних відносин, відповідає інтересам суб'єктів права, вирішує конфлікти, сприяє досягненню соціального компромісу в правовій сфері $[5$, с. 209-210; 7, с. 5, 7; 55, с. 41; 109, с. 5; 215 , с. $116-117 ; 233$, с. $247-248]$.

С. Бобровник та Н. Оніщенко, пропонуючи відмовитися від розуміння даного механізму лише як діяльності законодавця, котрий формує норму права, 
надає їй уповноважуючого, зобов'язуючого чи забороняючого характеру, та лише як виконання правового припису, підпорядкування забороні суб'єктами, яких цей припис стосується. При односторонньому підході до механізму правового регулювання нанівець зводиться мета та цілі правового регулювання, не враховуються різні фактори, які впливають на процес зазначеного регулювання $[17$, c. 15$]$

Механізм правового регулювання характеризується певними особливостями: є певною системою елементів, що взаємодіють між собою, серед яких виділяють правові засоби (норми, суб'єктивні права та юридичні обов'язки тощо), способи (дозволи, заборони і зобов'язання) та форми (дотримання, виконання і використання); він забезпечує регулювання суспільних відносин, тобто $є$ динамічною частиною правової системи; має цілеспрямований та результативний характер.

В. Нерсесянц зазначає, що механізм дії права - це механізм абстрактнозагальної правової регуляції, конкретизованої та індивідуалізованої стосовно конкретно-визначеного випадку вияву юридичної сили діючого права. У даному разі загальна норма набуває індивідуального характеру щодо конкретного випадку [140, с. 40-42]. Заслуговує на увагу позиція А. Зайця, який вважає, що право являє собою не тільки «явище у собі», а $є$ зовнішнім проявом, могутнім регулятивним засобом, що спонукає особу діяти відповідно до вимог права [74, с. 20, 37-38]. Інколи подається інший підхід до поняття механізму правового регулювання, коли розглядають його як певну систему юридичних засобів, організованих послідовно, що мають за мету подолання перешкод, які стають на шляху задоволення інтересів суб'єктів права [144, с. 321-323].

Отже, за допомогою механізму правового регулювання обгрунтовується необхідність здійснення правового регулювання в суспільстві, впорядковуються явища правової дійсності, забезпечується їх єдність, взаємозв'язок та взаємодія, відбувається процес трансформації правових приписів щодо реальної поведінки суб'єктів права. Виходячи з цих завдань, можна сформулювати таке визначення: 
правове регулювання - це цілеспрямований вплив на поведінку людей і суспільні відносини за допомогою правових (юридичних) засобів.

Регулюванням можна назвати тільки такий вплив, при якому ставляться досить ясно позначені цілі. Наприклад, з метою упорядкування використання землі, забезпечення іiі збереження, підвищення ефективності землекористування видається закон про землю, який містить вимоги до цієї сфери діяльності. I дію норм земельного права, в результаті якого реалізуються поставлені цілі, можна назвати правовим регулюванням.

У вузькому значенні під правовим регулюванням розуміється «вплив норм права» (системи правових норм), інших спеціально-юридичних засобів на поведінку людей і на суспільні відносини з метою їхнього упорядкування і прогресивного розвитку. Право має властивості і механізми, що забезпечують його реалізацію в житті суспільства. Нормативність, загальнообов'язковість, формальна визначеність, забезпеченість силою державно-правового примусу надають можливість перевести правові норми із сфери належного в сферу сущого, в повсякденне практичне життя людини і суспільства. Розкриття сутності правових явищ надає змогу розуміти регулятивну роль законів та інших нормативних актів, індивідуальних рішень, інших правових засобів у їх взаємозв'язку і взаємодії.

Якщо ж під впливом законодавчого акта або його норм настають наслідки, не передбачені законодавством, а в деяких ситуаціях і суперечать цілям законодавця, то такий вплив не може вважатися правовим регулюванням. Так само не можна вважати правовим регулюванням вплив, що здійснюється неюридичними засобами. Безумовно, у реальному житті духовний, ідеологічний, психологічний вплив права взаємопов'язаний i поєднується із спеціальноюридичним правовим регулюванням. Вплив на суспільні відносини, на поведінку людей спеціально-юридичними засобами і способами, у свою чергу, впливає на духовно-моральну, ідеологічну сторони життя людини.

Від характеру і змісту суспільних відносин, що становлять предмет правового регулювання, залежать особливості, характер, способи і засоби 
правового регулювання. Досить очевидно, що відносини з еквівалентного обміну цінностями, наприклад майнові відносини, вимагають інших правових засобів і способів регулювання, ніж ті, які використовуються для регламентації управлінських відносин. Характер, вид суспільних відносин, що становлять предмет правового регулювання, зумовлюють ступінь інтенсивності правового регулювання, тобто широту охоплення правовим впливом, ступінь обов'язковості правових приписів, форми і методи правового примусу, ступінь деталізованості приписів, напруженість правового впливу на суспільні відносини тощо.

Різноманітність суспільних відносин, що входять до сфери правового регулювання, породжує відмінності в методах юридичного впливу. У теорії правового регулювання прийнято виділяти два методи правового впливу [210, с. $235 ; 264$, c. 178].

Загальновизнано, що метод децентралізованого, диспозитивного регулювання побудований на координації цілей і інтересів сторін у суспільних відносинах суб'єктів громадянського суспільства, які відповідають, насамперед, приватним інтересам, тобто у сфері галузей приватноправового характеру. Так само юридична наука ставиться i до методу централізованого, тобто імперативного регулювання, що базується на відносинах субординації між учасниками суспільних відносин. Таким методом регулюються відносини, де пріоритетним, як правило, є загальносоціальний інтерес.

У державно-організованому суспільстві загальносоціальні інтереси виражає, в першу чергу, держава, яка здійснює централізоване управління соціальними процесами, наділена владними повноваженнями, що є загальнозначущими. Тому централізовані, імперативні методи використовуються у публічно-правових галузях, у тому числі для регулювання господарських відносин [96, с. 191; 36, с. 43; 77, с. 8-9; 237, с. 12-13]. У сфері стандартизації держава здійснює свій вплив не лише при визначенні обов'язкових вимог, а й при контролі за добровільними.

Поряд із методами слід зауважити про способи правового регулювання. Способи правового регулювання визначаються характером припису, 
зафіксованого у нормі права, способами впливу на поведінку людей. У теорії права прийнято виділяти три основні способи правового регулювання [232, с. 495-496]. Перший спосіб - надання учаснику правових відносин суб'єктивних прав. Він проявляється в делегуванні комплексу дозволів уповноваженій особі на вчинення певних дій (наприклад, лише після надання документів про підтвердження відповідності молока його дозволяється постачати у торгові мережі). Другий спосіб - зобов'язування як припис зробити якісь дії (так, суб'єкт господарської діяльності зобов'язаний дотримуватися правил безпеки та створювати умови для уникнення ризиків для життя і здоров'я працівників на виробництві). Третій спосіб - заборона, тобто покладання обов'язку утримуватися від певних дій (наприклад, при виявленні недоброякісної продукції внаслідок порушення температурних умов на суб’єкта господарської діяльності (виробника чи перевізника) покладається обов'язок надалі не порушувати ці умови або взагалі забороняється здійснювати цю діяльність).

Додатковими способами правового впливу можна назвати: застосування примусових заходів (наприклад, покладання юридичної відповідальності за скоєне правопорушення); попереджувальний (превентивний) вплив норм, який передбачає можливість застосування правового примусу [119, с. 64; 77, с. 124]; стимулюючий вплив норм права. Таким способом впливають заохочувальні норми, тобто норми, в яких передбачено заохочення за активну правомірну поведінку (за впровадження норм і вимог стандартизації, винахідницьку, раціоналізаторську діяльність) [7, с. 25].

Заслуговує на увагу позиція О.Ф. Скакун про виокремлення трьох основних способів правового регулювання: дозволів, заборон та зобов'язань, що відповідають регулятивно-статичній і регулятивно-динамічній функції права [232, c. 495-496]. Дозволи - важливий елемент правового регулювання, що забезпечують соціальну свободу та активність людини. Дозволи набувають юридичного характеру з моменту їх закріплення в уповноважуючих нормах у вигляді суб'єктивних прав та реалізуються у формі використання, що визначає 
добровільний характер, їх залежність від бажання суб'єкта, якому належить суб'єктивне право. Заборони встановлюють певну міру поведінки суб'єктів, покладаючи на осіб обов'язок утримуватись від вчинення певних дій, що протирічать нормам права. Вони - важливий засіб забезпечення організованості суспільних відносин, створення перешкод для небажаної, суспільно небезпечної чи шкідливої поведінки. Заборони мають обов'язковий характер, забезпечуються засобами юридичної відповідальності та знаходять закріплення у забороняючих нормах, реалізуються у формі дотримання правових норм. Зобов'язання - це нормативне закріплення юридичного обов'язку вчиняти певні дії в інтересах суб'єктів права. Даний вид юридичного обов'язку має активний характер, передбачає певну поведінку, є гарантією використання суб'єктивних прав i реалізується у формі виконання правових норм.

За допомогою правового регулювання відносини між суб'єктами набувають певної правової форми. Саме через норми права держава встановлює міру можливої та дозволеної поведінки. Способам правового регулювання відповідають регулятивно-статична та регулятивно-динамічна функції права. Покладаючи на осіб обов'язок утримуватися від вчинення певних дій, що протирічать нормам права, заборони встановлюють певну міру поведінки суб'єктів; дозволи забезпечують соціальну активність суб'єктів і певний рівень їх свободи; зобов'язання сприяють реалізації покладених на осіб обов'язків, їх виконання гарантується з боку держави у вигляді застосування юридичної відповідальності. Крім основних способів правового регулювання, виділяють ще і додаткові, такі як: стимулююча дія норм права, застосування засобів примусу, попереджувальна дія норм права [77, с. 124; 119, с. 64]. Наприклад, заохочувальними є норми, в яких передбачено стимулювання за впровадження норм i вимог стандартизації, винахідницьку, раціоналізаторську діяльність, що надає зиогу досягти мети господарської діяльності 3 найменшими економічними витратами [7, с. 25]. Виділення названих способів як додаткових пояснюється тим, що вони розглядаються як певний вид обов'язку. За допомогою цих засобів забезпечується 
належне використання наданих прав та виконання покладених на суб'єктів обов’язків, здійснюється утримання від заборон. На основі співвідношення загальних дозволів і заборон в юридичній літературі та правовому житті склалися дві юридичні формули, на основі яких виділяються два типи правового регулювання [207, с. 88-89]. зумовно, немає галузей права, побудованих лише на одному типі правового регулювання. Так, в цивільне право «вкраплені» елементи заборонного типу, а в адміністративному праві можуть зустрічатися норми, що регулюють відносини управління за типом загального дозволу. Так само при регулюванні стандартизації можливе застосування першого типу регулювання щодо принципу свободи господарюючих суб’єктів, а другий - при випуску продукції чи наданні послуг лише у межах вимог нормативно-технічних документів.

Досягнення цілей правового регулювання здійснюється за допомогою певних засобів, що є шляхами юридичного впливу на поведінку суб’єктів. Сукупність даних засобів, які є різними за своєю природою та функціональним призначенням, і складає формальну ознаку механізму правового регулювання [4, c. $14 ; 26$, с. $50 ; 55$, с. 41-42; 258, с. 68]. Ці правові засоби мають такі ознаки: складають певну систему, але не прив'язані до однієї сфери суспільних відносин; покликані забезпечити соціальну свободу та активність поведінки суб'єктів (дозволи), чи, навпаки, покласти на осіб пасивний обов’язок утримуватися від вчинення тих дій, які перешкоджають інтересам особи (заборони), передбачати поведінку певного роду, бути гарантією використання суб'єктивних прав іншими суб'єктами (зобов'язання); ці засоби повинні містити позитивні стимули щодо здійснення суб'єктами своїх суб'єктивних прав та виконання покладених на них обов’язків; мають бути спрямовані на досягнення певного результату забезпечення ефективності правового регулювання; пов’язані з суб'єктивними правами чи даної особи (дозволи), чи інших осіб (зобов’язання, заборони); ці засоби тісно взаємопов'язані не тільки один з одним, а й з такими різновидами правових норм, як уповноважуючі, зобов'язуючі та забороняючі, і визначають форми реалізації права (дотримання, виконання та використання). 
Терміни «спосіб», «засіб», «метод» близькі за змістом і у значній мірі збігаються. Правові засоби - це певні юридичні категорії та діяння суб'єктів 3 їх застосування з метою досягнення конкретного результату. До правових засобів Ю. Тихомиров відносить також дії: видання підзаконних нормативно-правових актів на основі, на виконання та у відповідності із законом, процес відміни та зміни цих актів, правильне застосування законів тощо [250, с. 312-314], а В. Горшеньов поділяє засоби правового регулювання на засоби впливу (зовнішні фактори щодо волі суб' єктів - це дозволи та заборони) та засоби реалізації права (результат реагування суб’єктів на правовий вплив - здійснення дозволених законом дій та утримання від заборонених дій) [39, с. 71, 73-74]. Не ототожнюючи ці поняття, слід засновуватися на думці, що основною метою способу, засобу та методу правового регулювання є рекомендації, як врегулювати ті чи інші відносини.

На нашу думку, стандартизація як правовий засіб характеризується певними ознаками: 1) має соціальну цінність, оскільки забезпечує досягнення поставлених цілей; 2) відображає інформаційні якості права; 3) поєднуючись із іншими засобами, створює умови для дії права; 4) викликає певні юридичні наслідки; 5) забезпечується примусовою силою держави [178].

В юридичній літературі засоби правового регулювання класифікують за певними критеріями. Залежно від ступеня складності розрізняють: прості (суб'єктивні права та юридичні обов'язки; заохочення і покарання; пільги та заборони) та складні засоби (норма; інститут). Залежно від функціонального призначення: регулятивні (дозволи); охоронні (засоби захисту). За предметом правового регулювання: конституційні, адміністративні, цивільні, господарські, кримінальні тощо. За характером: матеріальні (рекомендації) та процесуальні (позовні). За часом дії: постійні (дозвіл на здійснення певного виду господарської діяльності); тимчасові (встановлення лімітів на видобування надр суб'єктом господарської діяльності). Залежно від виду правового регулювання: нормативні (заборони, встановлені нормами права); індивідуальні (акт застосування права). Залежно від інформаційно-психологічної спрямованості: стимулюючі (заохочення); 
обмежуючі (примус). У господарському праві, зазвичай, йдеться про засоби державного регулювання господарської діяльності (ст. 12 ГК України), що $є$ економічними за своєю суттю: державне замовлення; ліцензування, патентування і квотування; технічне регулювання; застосування нормативів і лімітів; регулювання цін і тарифів; надання інвестиційних, податкових та інших пільг; надання дотацій, компенсацій, цільових інновацій та субсидій [91, с. 359; 228, с. 5-6; 236, с. 189; 272, c. $11-12 ; 280$, c. 1068].

32014 р. стандартизації немає у цьому переліку [176, с. 183-187], а iï виключення з ГК України обгрунтовувалося вступом до СС і підведенням національного законодавства до вимог міжнародних інституцій, але вона є саме тим засобом регулювання, що використовується при застосуванні засобів, перелічених у ст. 12 ГК України.

\section{2 Особливості стандартизації при впорядкуванні господарських правовідносин}

За загальною теорією предметом правового регулювання є суспільні відносини, які мають такі ознаки: по-перше, це відносини, в яких знаходять відображення як індивідуальні інтереси членів суспільства, так і інтереси загальносоціальні; по-друге, в цих відносинах реалізуються взаємні інтереси їх учасників, кожен з яких має певний утиск своїх інтересів заради задоволення інтересів іншої сторони; по-трете, ці відносини будуються на основі згоди виконувати певні правила, визнання обов'язковості цих правил; по-четверте, ці відносини вимагають дотримання правил, обов'язковість яких підкріплена досить дієвою силою (примусом) [72, с. $407 ; 73$, с. $146 ; 85$, с. $156 ; 104$, с. $80 ; 125$, с. $11-12$; 275, с. 14]. Історія правового життя суспільства засідчила, що до сфери правового регулювання входять три групи суспільних відносин. Першу групу складають 
відносини людей з обміну цінностями (як матеріальними, так і нематеріальними). Тут найбільш яскраво проявляється можливість i необхідність правового регулювання майнових відносин, бо у прийнятному та взаємозацікавленому обміні майном виявляється інтерес окремих осіб і суспільства в цілому. Ці відносини будуються на основі загальновизнаних правил (наприклад, визнання вираження цінності майна в грошовому еквіваленті), обов'язковість такого визнання правил забезпечена дієвою силою спеціального апарату правового примусу. Другу групу утворюють відносини 3 владного управління суспільством. В управлінні соціальними процесами так само зацікавлені окремі особи і суспільство. Управління здійснюється заради задоволення як індивідуальних, так i загальносоціальних інтересів і має реалізовуватися за суворими правилами, забезпеченими силою примусу. Саме тому природним $\epsilon$ те, що до сфери правового регулювання входить державне управління соціальними процесами. У третю групу входять відносини щодо забезпечення правового порядку, що покликані забезпечити нормальне функціонування попередніх груп відносин (обміну цінностями та управління в суспільстві). Це відносини, що виникають у разі порушення правил, що регламентують поведінку суб'єктів у двох зазначених сферах [3, с. 61-69; 56, с. 11-12; 72, с. 333-334; 275, с. 20-21].

ГК України визначає суспільні відносини, що є предметом правового регулювання у сфері господарської діяльності (організаційно-господарські, внутрішньогосподарські та господарсько-виробничі або договірні). Усі ці відносини можуть регулюватися за допомогою стандартизації. Розглянемо детальніше, на підставі яких актів та яким чином відбувається таке регулювання.

Під організаиійно-господарськими відносинами у ч. 6 ст. 3 ГК України розуміють відносини, що складаються між суб'єктами господарювання та суб'єктами організаційно-господарських повноважень у процесі управління господарською діяльністю. Організаційно-господарські відносини виникають, як правило, у сфері господарського управління [29, с. 214; 138, с. 10-12; 259, с. $25-$ 27; 248, с. 14-15]. Також ці відносини можуть виникати з приводу підтвердження 
відповідності товарів та/чи послуг вимогам нормативно-правових документів із стандартизації. Управління потребує постійного моніторингу ефективності та вдосконалення на основі такого аудиту [175, с. 160-161]. У світі застосовують два варіанти (рівні) оцінки: 1) самооцінка 3 допомогою системи CAF (The Common Assessment Framework); 2) професійна оцінка на основі серій міжнародних стандартів ISO 9000, ISO 14000, ISO 22000 тощо.

Основна мета системи CAF [69]: 1) впровадити у сферу адміністративного управління принципи менеджменту якості та сприяти їх розвитку за допомогою методу самооцінки. Сприяти переходу від ланцюга «плануй-роби» до циклу «плануй-роби-перевіряй-впливай» (цикл PDCA); 2) надати механізм для самооцінки організації з метою діагностування і поліпшення ії діяльності; 3) стати єднальним елементом між різними моделями менеджменту якості; 4) забезпечити обмін досвідом і вивчення кращої практики. САF створювався для державних інституцій, але, на нашу думку, він може стати регулюючим нормативнотехнічним документом для підвищення ефективності саморегулювання управлінських відносин суб'єктів господарської діяльності як з3овні, так і у внутрішній роботі керівництва та персоналу.

Вторинною (професійною) ланкою систем управління на підприємствах, установах та організаціях суб'єктів господарських відносин $є$ застосування стандартів ISO, що виконують соціальну (гуманістичну) функцію [33, с. 4-5]. Зокрема, сертифікація підприємств, установ та організацій за ISO 9001 гарантує, що підприємство може випускати продукцію на стабільному рівні якості та постійно його підвищувати [61]. Застосування ISO 9001 гарантує обов'язковість контролю якості на виробництві.

Застосування ISO 9001 гарантує обов'язковість контролю якості на виробництві.

На нашу думку, результативне функціонування системи ISO 9001 (менеджменту якості), а також наявність сертифіката відповідності цій системі надає велику перевагу для суб'єкта господарської діяльності, зокрема: 
1) підвищення рівня управління в межах функціонування суб'єкта господарської діяльності;

2) зниження витрат, що пов'язані з отриманням відбракованого товару;

3) збільшення кількості лояльних споживачів та розширення потенційного ринку збуту;

4) збільшення строку дії сертифікатів на товари та послуги, що підлягають обов'язковій сертифікації в Україні, з 3-х до 5-ти років;

5) конкурентні переваги (у тому числі під час участі у тендерах);

6) підвищення загальної репутації та іміджу суб'єкта господарської діяльності.

Для регулювання відносин, що можуть виникнути 3 третіми особами (споживачами), застосовується сертифікація систем менеджменту у сфері безпеки продовольства та харчової продукції за ISO 22000 [60]. Сертифікація за даним стандартом реалізує презумпцію відповідності та гарантує споживачам безпеку сировини, домішок та компонентів, що використовуються під час виробництва. Вона також забезпечує впевненість у тому, що суб’єкт господарської діяльності знає та контролює фактори ризику, які впливають на виробничий процес. Наразі системи управління безпечністю харчових продуктів застосовують практично в усьому світі як надійний захист споживачів від небезпек, які можуть супроводжувати харчову продукцію. До об’єктів НАССР відносять рибу та рибопродукти, свіжі горіхи, соки та нектарні вироби, продукти харчування, продукція для м'яса та птиці, а також діяльність у школах при наданні послуг 3 харчування. Запровадження систем управління безпечністю харчових продуктів вимагає законодавство ЄС, США, Канади, Японії, Нової Зеландії. В Україні застосування систем НАССР (Hazard Analysis and Critical Control Points) $є$ обов'язковим для всіх підприємств, які займаються виробництвом або введенням в оборот харчових продуктів (ст. 20 Закону України «Про безпечність та якість харчових продуктів», ст. 9 Закону України «Про дитяче харчування»). Запровадження системи управління безпечністю харчових продуктів на базі концепції НАССР надає підприємству змогу: 
- гарантувати випуск безпечної продукції за рахунок систематичного контролю на всіх стадіях виробництва;

- належним чином керувати всіма небезпечними чинниками, які загрожують безпечності харчових продуктів - запобігати, усувати чи мінімізувати ïx;

- гарантувати, що харчові продукти є безпечними на момент їх споживання в їжу;

- забезпечити належні гігієнічні умови виробництва згідно з міжнародними нормами;

- демонструвати відповідність застосовним законодавчим та нормативним вимогам щодо безпечності харчових продуктів; укріпити довіру споживачів, замовників та органів нагляду до продукції, що виробляється, та підвищити імідж підприємства;

- розширити мережу споживачів продукції та вийти на потенційні закордонні ринки;

- підвищити відповідальність персоналу за випуск безпечної продукції та забезпечити розуміння всіма робітниками підприємства першорядної важливості аспектів безпечності продукції.

Ще однією сферою управління, що забезпечується за допомогою стандартизації, є екологічний менеджмент [173, с. 230]. Впровадження стандартів ISO cерії 14000, що містять склад та опис елементів системи управління навколишнім середовищем, настанови з їх застосування, а також настанови щодо здійснення екологічного аудиту на підприємстві означає, що суб’єкт господарської діяльності прагне мінімізувати власний негативний вплив на довкілля. Крім стандарту ISO 14001, було розроблено серію стандартів на системи екологічного управління, багато 3 яких прийняті в Україні як ідентичні національні стандарти (ДСТУ) [58]. Ці стандарти рекомендовано використовувати як допоміжні під час впровадження та поліпшення системи екологічного управління та демонстрації ії відповідності заінтересованим сторонам. 
Вважаємо, що, впроваджуючи систему екологічного управління, кожен суб'єкт господарської діяльності повинен визначити законодавчі та інші регламентувальні вимоги щодо довкілля, які він зобов'язується виконати, що застосовані до екологічних аспектів діяльності, продукції чи послуг. Відповідність суб'єкта господарської діяльності законодавчим і нормативним актам $\epsilon$ одним 3 важливих критеріїв аудиту під час сертифікації системи екологічного управління (ст. 5 Закону України «Про екологічний аудит»). Ця система $є$ інструментом, який дає можливість визначити екологічні аспекти діяльності, продукції чи послуг, оцінити їх вплив на довкілля, розробити та впровадити дії із запобігання забрудненню, встановити контроль за впливом та застосовувати коригувальні заходи, визначити застосовні екологічні законодавчі та нормативні вимоги, забезпечити діяльність у відповідності до екологічного законодавства України, визначати та досягати екологічних цілей, поліпшувати екологічні характеристики, збалансувати та інтегрувати економічні й екологічні інтереси, своєчасно адаптуватися до умов, що постійно змінюються.

Нещодавно у сфері господарської діяльності розпочали діяти два нові закони з екологічним спрямуванням (закони України «Про оцінку впливу на довкілля» від 23.05.2017 № 2059-VIII та «Про стратегічну екологічну оцінку» від 20.03.2018 № 2354-VIII) [202; 203]. Вони мають забезпечити правові й організаційні засади здійснення оцінки впливу на довкілля та забезпечення виконання Україною міжнародних зобов'язань у рамках Конвенції про оцінку впливу на навколишнє середовище у транскордонному контексті (Конвенція Еспо) та Конвенції про доступ до інформації, участі громадськості в процесі прийняття рішень і доступу до правосуддя з питань, що стосуються довкілля (Оргуська конвенція), стороною яких є Україна, імплементації у національне законодавство положень Директив 2003/4/СС та 2011/92/СС, а також застосування і здійснення стратегічної екологічної оцінки відповідно до підходу, закріпленого у директиві Європейського парламенту та Ради ЄС від 27.06.2001 p. 2001/42/€C. 
Вважаємо впровадження ефективної системи екологічного управління необхідним елементом ведення господарської діяльності в умовах глобалізації ринків збуту, до потенційних вигод якого належать:

- поліпшення репутації організації в очах громадськості, органів державної влади, інвесторів;

- поліпшення взаємодії з постачальниками й споживачами;

- укладання договорів страхування з прийнятними внесками;

- отримання права на пільгове оподаткування;

- вдосконалення управління витратами;

- зменшення кількості інцидентів, що призводять до юридичної відповідальності;

- заощадження сировини, матеріалів та енергії.

Зі зростанням масштабів виробництва та технологічних можливостей збільшується масштаб наслідків від аварій, а також небезпека для здоров'я і життя співробітників, насамперед тих, що виконують роботи 3 підвищеною небезпекою. Особливо високий ступінь ризику на підприємствах нафтогазового комплексу, добувної та хімічної галузей промисловості, будівельної індустрії. Сьогодні виробничі компанії прагнуть, 3 одного боку, зменшити витрати, пов'язані 3 охороною здоров'я та безпекою праці, з іншого - підвищити безпеку виробництва, ефективно керуючи пов'язаними 3 ним ризиками для людини, й одночасно поліпшити корпоративний імідж. 3 цією метою, підприємства всього світу ще 3 1999 р. впроваджують у себе системи управління професійною безпекою та здоров'ям, орієнтуючись на вимоги міжнародного стандарту OHSAS 18001 [284].

Для організаційно-господарських відносин стандартизація виступає у двох якостях: 1) як основа регулювання (створення норми права чи локального нормативно-правового акта); 2) як засіб регулювання. Нормативно-технічні документи зі стандартизації систем управління виступають зовнішньою формою норм (вимог) та способів організації, а також здійснення управлінської діяльності. 
Внутрішньогосподарськими є відносини, що складаються між структурними підрозділами суб'єкта господарської діяльності, та його відносини 3 власними структурними підрозділами (ч. 7 ст. 3 ГК України). Внутрішньогосподарські відносини - це той різновид господарських відносин, які виникають безпосередньо у внутрішній виробничій сфері підприємств та інших господарських організацій, а їх суб’єктами стають саме внутрішні підрозділи підприємств (цехи, виробництва тощо). Вони вступають у відносини між собою, а також із господарюючим суб’єктом у цілому, до складу якого входять. Права та обов'язки учасників внутрішньогосподарських відносин, як правило, визначаються локальними нормативними актами суб'єктів господарської діяльності. Не виключається також можливість укладення внутрішньогосподарських договорів. Локальні акти мають бути модифікатором, що перетворює загальні вимоги в конкретні процедури, реалізуючи ці правила в повсякденній діяльності суб’єктів господарської діяльності [6, с. 214; 102, с. 54, 57; 118, с. 197-201; 215, с. 111]. Предметом локальних актів є спільна діяльність суб'єктів (частин суб'єктів господарської діяльності, членів, учасників, працівників), що вступили між собою в правовідносини в рамках окремо взятого суб'єкта господарської діяльності. У зв’язку з цим локальна нормотворчість спрямована на впорядкування, нормування суспільних відносин, що складаються в рамках даної правової локації. Законодавець надає можливість суб’єктам господарської діяльності самим виробляти умови співробітництва, визначати за згодою сторін або в односторонньому порядку створення норм для забезпечення внутрішнього розпорядку, видів та порядку здійснення робіт. Прийняті ними норми $\epsilon$ обов’язковими правилами належної поведінки для всіх частин суб'єктів господарської діяльності, членів, учасників, працівників.

Локальна нормотворчість залежить від рівня правової культури та правової свідомості осіб, що займаються створенням цих норм [35, с. 11-12; 37, с. 24; 171 ; 208 , с. $112 ; 227$, с. $35 ; 230$, с. 330-331]. Про важливість правової культури, правосвідомості та правового виховання при здійсненні господарської діяльності 
йшлося рідко $[77$, с. $13 ; 152$, с. $4-5 ; 166$, с. $385 ; 227$, с. $36-37 ; 241$, с. 400]. На нашу думку, саме від правової культури та правової свідомості людини, що розробляє для суб’єктів господарської діяльності локальні акти, залежить створення такої системи локальних норм права, що має адекватно відображати умови економічної, виробничої і технологічної діяльності цього суб'єкта. Правове регулювання за допомогою локальних норм веде до підняття правового регулювання на новий щабель, робить його адекватним пережитому етапу розвитку суспільства і в цьому сенсі робить на нього конструктивний вплив. Випереджаюче регулювання слугує способом вирішення протиріч у розвитку самої правової форми. Таке регулювання показує необхідність зміни правових норм, які прийшли в протиріччя з потребами життя, або їх скасування, прийняття нових, що відображають тенденції суспільного розвитку. Локальне регулювання виявляє недоліки законодавчого регулювання, виступає як форма критики існуючих нормативно-правових актів. Вважаємо, що для досягнення мети правового регулювання господарської діяльності внутрішньогосподарські відносини суб'єктів господарської діяльності мають засновуватися на ДСТУ 1.493 «Державна система стандартизації України. Стандарти підприємства. Основні положення» [56]. Локальні акти суб'єктів господарської діяльності мають відповідати вказаному стандарту, навіть якщо у назві не зазначається, що це стандарт підприємства. У стандартах підприємства (локальних актах) об’єктами регулювання можуть виступати: 1) загальні функції організації і виконання робіт iз забезпечення якості продукції (процесів, послуг), формулювання й удосконалення систем якості; 2) функції управління і забезпечення діяльності підприємства; 3) продукція (напівфабрикати, матеріали, що комплектують вироби, складені одиниці); 4) процеси виробничого циклу; 5) технологічне обладнання й інструменти, що виробляються і використовуються на даному підприємстві; 6) послуги, що надаються даним підприємством. На товари та послуги, що призначені для самостійного постачання, зазвичай розробляються не стандарти підприємства, а ТУ. 
Як i для попереднього виду господарських відносин, так i для внутрішньогосподарських стандартизація виступає у двох якостях: 1) як основа регулювання (створення норми права чи локального нормативно-правового акта, спрямованих на впорядкування діяльності власних структурних підрозділів); 2) як засіб регулювання міжструктурних особливостей діяльності, розмежування сфер діяльності окремих одиниць підприємства тощо. Нормативно-технічні документи зі стандартизації так само виступають зовнішньою формою норм (вимог) та способів організації діяльності.

Розглянемо врахування вимог нормативно-технічних документів iз стандартизації в договірних відносинах суб’єктів господарської діяльності в Україні. Ці правовідносини створюють механізм «переведення» загальних норм об’єктивного права у площину суб’єктивних прав і обов’язків, що може мати форму господарського чи іншого виду договору. Договір як засіб правового регулювання розглядався часто і детально. Він може породжувати факти та регулювати конкретні правовідносини.

Засновуючись на позиції, що договір поєднує у собі норми-дозволи, нормизаборони та норми-приписи та містить суспільно необхідні обмеження [14, с. 75; 28 , c. $276-277 ; 41$, c. $170-172 ; 125 ; 138$, c. $14 ; 220 ; 248 ; 273$, с. $366-368 ; 275$, с. $298-$ 300], можна вести мову про стандартизацію як засіб виконання мети господарської діяльності - досягнення економічних і соціальних результатів 3 отриманням прибутку чи без нього. Стосовно питання мети господарської діяльності, що у такому формулюванні закріплена у ГК України, то не всі вчені погоджуються 3 нею. Така позиція засновується на тому, що не цілком визначеним є поняття некомерційної діяльності (суб’єкта такої діяльності), що спричиняє певні непорозуміння [276, с. 116, 117]. Ми керуємося нормативним визначенням, оскільки як комерційна, так i некомерційна діяльність та іï результати мають відповідати вимогам стандартизації.

У договірній діяльності не можна обійтися без принципу справедливості, що гарантує баланс ринку, створює добросовісну конкуренцію та забезпечується за 
допомогою нормативно-технічних документів із стандартизації. Стандартизація крім обмеження договірних відносин створює упорядкованість і чіткість при формулюванні (визначенні) предмета договору, прогнозує ймовірні відносини відповідальності за недотримання (невиконання) вимог нормативно-технічних документів із стандартизації та $є$ фактором, що забезпечує публічні інтереси при здійсненні господарської діяльності. Нечіткість формулювання предмета договору, у тому числі не зазначення вимог стандартизації, яким мають відповідати товари (послуги), призвела до виникнення судових спорів. Хоча $є$ й інші випадки. Так, ДП науково-виробничий комплекс газотурбобудування «Зоря-Машпроект» при закупівлі продукції у договорі поставки має такі чіткі вимоги до якості товару (обладнання чи продукції, у тому числі щодо гарантійних зобов’язань) [249]:

1. Якість, комплектація, пакування й маркування товару (обладнання чи продукції) повинні відповідати чинним державним стандартам, ТУ, технічній документації на даний вид товару (обладнання чи продукції), сертифікатам якості виробника товару (обладнання чи продукції), а також спеціальним вимогам, передбаченим у специфікації. Найменування державних стандартів і ТУ, інші вимоги, яким повинна відповідати якість товару (обладнання чи продукції), обов'язково зазначаються в специфікації;

2. На товар (обладнання чи продукцію), внесені до «Переліку продукції, що підлягає обов'язковій сертифікації в Україні», постачальник в обов'язковому порядку має надати сертифікат відповідності;

3. У разі ненадання (надання в неповному обсязі) вищезазначених супровідних документів або надання неналежно оформлених супровідних документів, товар (обладнання чи продукція) вважається непоставленим або неналежно поставленим (у разі надання не в повному обсязі супровідних документів або надання неналежно оформлених супровідних документів).

Це унеможливлює відхід від вимог до товару, що буде поставлятися за договором. У колишньому СРСР стандартизація слугувала вертикальним зв'язком між суб'єктами господарської діяльності в процесі виникнення та розвитку 
договірних відносин. У сучасних умовах стандартизація може ставати вертикальним запобіжником у випадках необхідності гарантування інтересів третіх осіб (побічних споживачів, суспільства в цілому чи довкілля). Уявляється, що 3 введенням принципу добровільності стандартизація має виступати в горизонтальній площині як істотна умова договору та оптимальний зв’язок між державою та суб’єктом господарської діяльності, а також між суб’єктами господарської діяльності без участі держави.

Нині виникає об’єктивна необхідність внесення безпосередньо у текст договору імперативної умови (перелік технічних регламентів, стандартів чи інших нормативно-технічних документів, а не відсилань у вигляді «відповідно до існуючих норм, правил»). Це особливо стосується публічних договорів (за тлумаченням у ст. 633 ЦК України), коли суб’єкт господарської діяльності виступає сильною стороною, а інша сторона (споживач) може покладатися лише на добросовісність та не може запобігти зловживанням із сторони суб'єкта господарської діяльності.

Застосування вимог нормативно-технічних документів зі стандартизації є умовою, що забезпечує не лише інтереси та потреби окремих (прямих) споживачів, а й створює умови для здійснення державою своїх прямих обов’язків (безпека для життя і здоров’я людини та охорона довкілля). Наприклад, наявність окремої комірки на стенді з інформацією для споживача, де розміщуються копії сертифікатів чи інших документів, що підтверджують якість та відповідність товарів (послуг), підвищує довіру від споживача та надає суб'єкту господарської діяльності конкурентну перевагу та можливість зростання прибутків.

Так само, в Інтернет-точках продажів товарів (послуг) велику довіру споживачів викликає наявність сертифікатів чи інших документів, що підтверджують якість і відповідність. Інтернет-магазин «Lire Of Car» на своїй сторінці в мережі Інтернет повідомляє про наявність у них сертифікатів на товари, що продає цей магазин [101]: від Ніко Трейдінг на продаж моторних олив Mobil 1 та Mobil Super; від Шелл Хелікс на продаж оригінальних мастильних матеріалів 
«Шелл»; від Авто Стандарт Груп про офіційне дилерство; від Інтер Карс про дистрибуцію запчастин для автомобілів; від Bita Trading GmbH на продаж продукції ТМ Бізол; від Каминьон Оіл на продаж продукції ТM Liqui Moly.

Згадана вище точка продажу за перший рік своєї діяльності уклала понад 5 тисяч публічних договорів. На нашу думку, цьому сприяла наявність у продавця (суб'єкта господарської діяльності) відповідних нормативно-технічних документів, що засвідчували якість проданих товарів.

У господарському договорі допускається встановлення більш жорстких (підвищених) вимог до товарів (послуг), ніж у нормативно-технічних документах із стандартизації або створення «під договір» нових вимог стандартизації, які мають містити більш жорсткі або просто інші вимоги. Наприклад, сьогодні в Свропі існує потреба у сої та продуктах з неї. Основною вимогою для поставки сої $є$ ії чистота, тобто відсутність ГМО. ГМО-сорти використовують лише для кормів окремих тварин. Для контролю поставок продукції сої та надання преференцій фермерам (чи господарствам), що їх вирощують, існують дві організації - Французька соєва асоціація та Асоціація «Дунайська соя». Ці організації $є$ неурядовими, але надають сертифікати для поставки сої в Швейцарію, Австрію, Німеччину, Францію та інші ринки Західної Європи [107].

Вони мають власні стандарти (правила) для виробництва сої, у тому числі методів іï вирощування, органічного підвищення продуктивності, технології вирощування та відбору найкращого насіннєвого матеріалу. Сертифікацією займаються органи SGS (в Україні - Organic Standard), які підтверджують відповідність саме вимогам Асоціації «Дунайська соя», що $є$ на порядок вищі та суворіші за чинні в Україні та Європі. Українські виробники, такі як корпорації «Сварог Вест Груп» [93], отримуючи сертифікати відповідності від Organic Standard про дотримання вимог Асоціації «Дунайська соя», мають змогу укладати експортні контракти на поставки сої на ринки Свропи, отримуючи не лише європейську ціну, а й преференції для подальшого розвитку власного бізнесу. 
У разі здійснення господарської діяльності в певній сфері, що регулюється технічними регламентами, де передбачено обов'язкові вимоги до товарів (послуг), не зазначення у договорі необхідності відповідності цим вимогам усе одно спричиняє негативні наслідки та не скасовує обов'язковість таких вимог. Тобто імперативи, встановлені технічними регламентами, діють незалежно від того, чи відомо про них суб’єктам господарської діяльності та чи вносять вони ці вимоги до договорів. Разом із тим добровільні вимоги нормативно-технічних документів із стандартизації у такій самій ситуації не породжують зобов'язання виконати їх. Лише декларація виконання добровільних вимог переводить їх в імперативне поле, а невиконання (недотримання) породжує негативні наслідки.

Це можна прослідкувати у таких судових справах:

1. Рішення господарського суду Закарпатської області у справі № 3/33 від 16.09.2010 p. [212]. ТОВ «Еліт», с. Гирка Полонка Луцького району Волинської області заявлено позов до ТОВ «Рубінкінг Україна», м. Ужгород про стягнення суми 68117 грн. 76 коп. вартості неякісного товару. Належна якість товару на момент його передання позивачу підтверджена документами, що посвідчували його якість -висновком державної санітарно-епідеміологічної експертизи № 05.03.02-03/51110 від 12.10 .2007 р. та міжнародним сертифікатом якості виробника від 10.03.2009 р. типу ISO 9001:2000 та типу IQNet \& MSZT від 25.03.2009 р., а також фактом прийняття позивачем товару без зауважень. Отже, псування товару відбулось у процесі його зберігання, яке мало здійснюватись відповідно до ТУ виробника -Технічних даних на Bigne ST028, затверджених 01.09.2007 року. Пунктом 8 зазначених Технічних даних передбачено, що продукт має зберігатися при відносній вологості повітря 55-65\%. Витяг з журналу контролю температури і вологи повітря в складі зберігання сировини протягом всього періоду зберігання товару на складі засвідчив, що вологість повітря складала 70\%, тобто перевищувала гранично допустиму для даного виду товару норму. Відповідно до ст. 268 ГК України якість товарів, що постачаються, повинна відповідати стандартам, ТУ, іншій технічній документації, яка 
встановлює вимоги до якості товарів. Придбаваючи товари іноземного виробництва, позивач згідно з ч. 2 ст. 268 ГК України мав витребувати $у$ постачальника технічну документацію, щุо встановлює вимоги до якості товарів. Твердження представника позивача про відсутність у нього таких документів судом до уваги не бралася, що, на нашу думку, є цілком правильною позицією.

2. Рішення Господарського суду Чернігівської області у справі № 927/372/15 від 12.05.2015 p. [213]. Заявлено позов військового прокурора Київського гарнізону про стягнення з ФОП ОСОБА_1 9000 грн. штрафу за поставку неякісного товару на підставі договору № 27/B33-2014 від 05.05.2014 р. на закупівлю чорного чаю. 05.05.2014 р. між сторонами укладено договір 27/B332014, відповідно до умов якого ОСОБА_1 (учасник) зобов’язалася у 2014 p. поставити в/ч 3078 (замовник) товари, визначені у специфікації, а замовник прийняти і оплатити такі товари (п. 1.1.). На підтвердження якості товару відповідач надав складене ним посвідчення про якість № 9-05/14 з посиланням на висновок державної санітарно-епідеміологічної експертизи № 05.03.02-03/3772 від 29.01.2013 р. 3 цим висновком. Однак у висновку державної санітарноепідеміологічної експертизи від 29.01.2013 р. № 05.03.02-03/3772 зазначено про його дійсність до 29.01.2014 р. на обсяг партії згідно з контрактом № 38 від 16.01.2013 р. «Фондова Компанія «Альянс» (Україна) та «Geo Plant LTD» (Грузія). Згідно 3 п. 5.6. договору замовник має право відкласти приймання товару за кількістю та якістю у разі, якщо учасник не надав відповідні підтверджуючі (кількість та якість товару) документи або є сумніви щодо якості товару після проведення огляду, - на строк до надання учасником цих документів або встановлення відповідної якості товару. Замовник, за таких обставин, не відклав приймання товару за якістю. Акт позивача від 05.05.2014 р. прийому товарів на зберігання у зв’язку з виявленням супроводження товару неповним пакетом документів не вказує про відкладення прийому товару за якістю та прийняття товару саме на зберігання, оскільки складений в односторонньому порядку. У 
накладній № 9/221/55 про передачу відповідачем позивачеві 1000 кг чаю чорного за підписом обох сторін відсутні застереження з цього приводу. За ч. 8. ст. 268 ГК України покупець (одержувач) може відмовитися від прийняття товарів, які не відповідають за якістю стандартам, ТУ, зразкам (еталонам) або умовам договору. Проте такої відмови не відбулося. Натомість позивачем платіжним дорученням № 1015 від 12.05.2014 р. перераховано 45000 грн. відповідачеві за чай згідно 3 договором 27/В33-2014 від 05.05.2014 р., накладною № 9 від 05.05.2014 року. Відповідно до п. 4.1 договору розрахунки за товар, що поставляється, замовником проводяться шляхом оплати за фактично поставлену кількість товару (партію товару). Тобто оплата чаю вказує на його прийняття. На нашу думку, суд правомірно відмовив у задоволенні вимог.

3. Рішення Господарського суду Харківської області у справі № 922/1549/16 від 12.07.2016 p. [214]. ТОВ «НВП Машинобудівник» звернулося до господарського суду Харківської області з позовом до ТОВ «АМО 1», у якому просить зобов'язати відповідача повернути сплачену за продукцію неналежної якості (чотири машинокомплекти редуктора ОГШ-75) суму у розмірі 159.695,60 грн. внаслідок відмови позивача від договору (в частині специфікації № 5). В обгрунтування позову вказує на те, що відповідачем за договором від 23.01.2014 p. № 7 був поставлений товар неналежної якості, що підтверджується актом № 21/15 від 07.08.2015 р., актом експертизи № 4-ВН від 08.04.2016 р. Харківської торгово-промислової палати (мав приховані недоліки). Між ЕFТА «НВП Машинобудівник» (замовник, позивач) та EFTA «AM0 1» (постачальник, відповідач) було укладено договір від 23.01.2014 р., відповідно до умов п. 1.1 якого постачальник зобов'язався виготовити деталі за документацією замовника та передати їх у власність останнього, а замовник, в свою чергу, зобов'язався прийняти деталі та сплатити їх вартість. Згідно 3 пп. 1.2.1 п. 1.2 договору замовник зобов'язується у строк не пізніше 3-х календарних днів 3 моменту підписання сторонами окремої специфікації передати постачальнику комплект Конструкторської документації на продукцію, достатній для виготовлення 
продукції за вищевказаною специфікацією. Згідно з пунктом 4.2 договору прийом продукиії за даним договором по якості і кількості відбувається замовником відповідно до вимог конструкторської документащії. Посилання позивача, що недоліки товару є прихованими і їх не можна було встановити при звичайному прийманні, також не підтверджуються матеріалами справи, оскільки товар, отриманий позивачем, фактично $є$ набором запчастин, кожну з яких можливо обміряти при прийомці на відповідність конструкторській документації і зазначений обов'язок позивача, закріплений у договорі. Суд критично оцінив акт експертизи № 4-ВН від 08.04.2016 р. Харківської торгово-промислової палати, оскільки доказів того, що експертиза проводилася відносно товару, отриманого за видатковою накладною № A-012-19/5 від 19.12.2014 р., в матеріалах справи не міститься і позивачем суду не надано. На нашу думку, ключовим моментом при вирішенні цієї справи стало неповне закріплення у договорі істотних умов (передання не запчастин, що відповідають вимогам нормативно-технічних документів, а саме комплектного виробу, що відповідає конструкторській документації).

Усі три рішення підтверджують тезу про обов'язок сторін дотримуватися спеціальних вимог до товарів (послуг) при укладанні договорів та про необхідність власного контролю за отриманням та вивченням тих вимог стандартизації, на які є посилання у підписаному сторонами договорі.

На нашу думку, у разі реалізації товару (надання послуг), що має відповідати локальним нормативно-технічним документам із стандартизації, що застосовуються лише цим суб'єктом господарської діяльності, у договорі слід прямо зазначити про необхідність їх надання одночасно з товаром (послугою). Так само слід передбачати обов'язкове надання стандартів підприємств одночасно з передачею прав інтелектуальної (промислової) власності, якщо товар (послуга) не може вироблятися (надаватися) окремо від вимог таких нормативно-технічних документів.

Договір має на меті сприяння покращенню виробництва, поширенню товарів та послуг, нівелюванню ринкових бар'єрів, 3 підвищенням якості та 
відповідальності сторін, а стандартизація (ії результати у вигляді нормативнотехнічних документів) $\epsilon$ необхідною та обов'язковою умовою договорів при здійсненні господарської діяльності та для забезпечення іiї здійснення.

Через договори суб'єкти господарської діяльності застосовують один 3 елементів механізму правого регулювання - акти безпосередньої реалізації прав і обов'язків у механізмі правового регулювання. Акти безпосередньої реалізації прав і обов'язків пов'язані зі здійсненням (реалізацією) прав і обов'язків та мають два прояви (активний та пасивний). Якщо активними діями реалізуються права, то має місце використання правових норм, а коли обов'язки - має місце виконання правових норм. Так, у ДСТУ 3718:2007 «Солодкі страви, желе, муси, пудинги, концентрати молочні: загальні технічні умови» вказано, що світлозабарвлені муси і плодово-ягідні желе виготовляють 3 масовою часткою ягідних (плодових) екстрактів не менше, ніж 30 \% [58]. виробника $є$ право покласти у таке желе (мус) від $30 \%$ до $100 \%$ ягідних (плодових) екстрактів та поставляти цей товар як відповідний вимогам, про що прямо зазначати у договорах. Пасивним проявом може бути рекомендація утримуватися від заборонених дій (не завдавати шкоди довкіллю). Наприклад, ДСТУ 3718:2007 чітко вказує, що при виготовленні мусів та желе використовують молоко незбиране сухе розпилювального сушіння вищого гатунку, виготовлене та упаковане згідно із ДСТУ 4273:2003 [58, с. 7]. Якщо господарюючий суб’єкт виготовляє продукцію на підставі чинного стандарту, здійснює оцінку відповідності товару та надає ці документи своїм контрагентам, то він утримується від протиправних дій та дотримується норм права. Тобто стандартизація надає додаткових гарантій учасникам господарських відносин та допомагає реалізовувати свої правомочності. 


\section{3 Особливості правового статусу суб'єктів стандартизації}

Учені пропонують відрізняти поняття «господарські відносини» від поняття «відносини у сфері господарювання» зважаючи на перелік учасників, які співвідносяться як частка й ціле [27, с. 28-29; 41, с. 5; 274, с. 21]. Відповідно, коло учасників «відносин у сфері господарювання» ширше за коло учасників господарських відносин. Саме тому до сфери господарської діяльності можна віднести відносини, що регулюють питання стандартизації товарів, послуг, процесів з метою дотримання принципів господарської діяльності та виконання завдань, що покладаються на учасників господарських відносин. Вважаємо, що суб'єктами стандартизації як засобу регулювання господарської діяльності можна називати фізичних та/чи юридичних осіб, що здійснюють діяльність із встановлення та/чи застосування вимог стандартизації, у тому числі технічного регулювання та оцінки відповідності.

Вважаємо, що саме про це йдеться у ч. 3 ст. 3 ГК України: «до відносин у сфері господарювання також належать ті, що складаються під час матеріального забезпечення діяльності суб'єктів - юридичних осіб, які в силу діяльності не можуть отримати статус суб'єкта господарської діяльності». Йдеться, зокрема, про установи (органи влади, органи місцевого самоврядування тощо) та інших юридичних осіб, які ГК України спеціально визначені як негосподарюючі (ст. 52 ГК України), але їх діяльність спрямована на створення і підтримку необхідних матеріально-технічних умов їх функціонування та здійснюється за участі або без участі суб’єктів господарювання (не є господарською діяльністю, а лише господарським забезпеченням діяльності цих суб'єктів). Вступаючи в правові відносини на основі певних юридичних норм, суб'єкти набувають суб'єктивних прав та юридичних обов'язків за власним бажанням (активна форма реалізації суб'єктивних прав і юридичних обов'язків) чи на основі правозастосовного акта (складна форма реалізації суб'єктивних прав та юридичних обов’язків). Як 
вважають А. Вітченко та Ю. Толстой, норма права починає регулювати поведінку суб'єктів не з моменту видання норми права, а з часу настання юридичних фактів, передбачених даною нормою [25, с. 92; 251, с. 7]. Це основний та найважливіший етап правового регулювання. Суб'єкти господарської діяльності реалізують свої права та обов'язки у сфері стандартизації як у простій (активній) формі, так і в складній. Зазвичай ці форми поєднуються. Зокрема, суб’єкти господарської діяльності мають право у відповідних сферах діяльності та з урахуванням своїх господарських і професійних потреб організовувати та виконувати роботи із стандартизації (ст. 16 Закону України «Про стандартизацію»). Правомочності суб’єктів стандартизації як засобу регулювання господарської діяльності такі:

1) розробляти, приймати, перевіряти, переглядати та скасовувати стандарти, кодекси усталеної практики, ТУ і зміни до них, установлювати процедури їх розроблення, прийняття, перевірки, перегляду, скасування та застосування;

2) застосовувати прийняті ними стандарти, технічні умови тощо;

3) брати участь у роботі спеціалізованих міжнародних і регіональних організацій стандартизації відповідно до положень про такі організації;

4) створювати та вести фонди нормативних документів і видавати каталоги нормативних документів для забезпечення своєї діяльності та інформаційного обміну;

5) видавати і поширювати прийняті ними стандарти, кодекси усталеної практики та ТУ, документи відповідних спеціалізованих міжнародних організацій стандартизації, членами яких вони є чи 3 якими співпрацюють на підставі положень про такі організації або відповідних договорів. У такому разі використання правомочності створює складну форму реалізації.

Нормативно-технічні документи (стандарти, кодекси усталеної практики, ТУ тощо), прийняті суб'єктами стандартизації, застосовуються ними на добровільній основі. Прийняття таких нормативно-технічних документів, а також каталогів з їх переліком створюють нову правомочність у суб’єктів господарської діяльності - право власності на ці документи. За Законом України «Про технічні 
регламенти та оцінку відповідності» реалізація правомочностей суб'єктів стандартизації здійснюється також шляхом покладання обов'язків. Наприклад, обов'язком виробника, постачальника чи інших суб'єктів господарської діяльності є відповідність введених в оборот, наданих на ринку або введених в експлуатацію в Україні товарів чи послуг вимогам усіх чинних технічних регламентів, що застосовуються до такої продукції, вона $є$ обов'язковою, за винятком випадків, визначених у зазначених технічних регламентах та ст. 12 Закону України «Про технічні регламенти та оцінку відповідності». Для найповнішої реалізації прав суб’єктам стандартизації надається свобода дій при виробництві (постачанні) товарів і наданні послуг. Така позиція випливає 3 презумпції відповідності.

Усі відносини, що за визначенням ГК України належать до господарських, безпосередньо або опосередковано пов'язані зі здійсненням господарської діяльності їх учасниками. За ст. 2 ГК України до учасників відносин у сфері господарювання відносять суб'єктів господарювання, в тому числі підприємців, споживачів, органи державної влади та органи місцевого самоврядування, наділені господарською компетенцією, а також громадян, громадські та інші організації, які виступають засновниками суб'єктів господарювання чи здійснюють щодо них організаційно-господарські повноваження на основі відносин власності.

Правосуб'єктність суб'єкта господарювання доктринально визначається як господарська компетенція, тобто сукупність встановлених законодавством і набутих у господарських правовідносинах прав і обов'язків [5, с. 152; 73, с. 152$153 ; 122$, c. $62 ; 271$, c. 5,7$]$.

Господарсько-правова наука традиційно розглядає господарську правосуб'єктність як узагальнену характеристику господарської компетенції [23, с. $613 ; 121$, с. $58-59 ; 247$, с. $66-69]$. При цьому у господарському праві прийнято відносити до господарської компетенції права та обов'язки, у тому числі правоздатність, що тлумачиться як «право на право». Деякі вчені вважають, що 
господарська правосуб'єктність визначається як дві складові: 1) господарська компетенція, тобто конкретні права та обов'язки щодо здійснення господарської діяльності та управління нею; 2) господарська правоздатність, тобто можливість своїми діями набувати права і обов'язки [15, с. 400-401].

$€$ й більш широкі тлумачення. Так, С. М. Грудницька $[43$, с. 5] розглядає господарську правосуб'єктність як абстрактну властивість суб'єкта господарювання, яка конкретизується в усіх правах і обов'язках, що формуються у складноорганізованому процесі збалансування приватних і публічних інтересів і встановлення меж приватних і публічних влад, що гарантують реалізацію інтересів [44, с. 67], та пропонує розрізняти при характеристиці господарської правосуб'єктності такі поняття: об'єктивні права, обов'язки і свободи, суб'єктивні права, обов'язки і свободи, статусні права, обов'язки і свободи (правовий статус), компетенція, повноваження, правоздатність, поточні права, обов'язки і свободи, потенціальні, формальні та реальні права, обов'язки і свободи, організаційноправова форма, правовий інститут, інституційні права, обов'язки і свободи [43, с. 5]. Господарська правосуб'єктність, на іï думку, є найбільш широким поняттям, що включає в себе всі права і обов'язки суб'єкта господарювання, основний блок яких становить господарська компетенція, до складу котрої в якості основного повноваження входить господарська правоздатність [45, с. 56-57].

У сфері стандартизації немає єдиного підходу до класифікації суб’єктів. Так, Н. Я. Лепіш до суб’єктів у сфері стандартизації, якості продукції, метрології та сертифікації відносить суб'єктів: 1) стандартизації; 2) сертифікації; 3) метрологічної служби [113, с. 302]. К. Б. Починок говорить суто про трирівневу структуру, тобто наявність суб'єктів вищого, центрального та місцевого рівнів [194, с. 266-267]. В. Ю. Волков поділяє суб'єктів за спеціалізацією (напрямами контролю) [31, с. 148 Д. І. Сакоян розглдяає лише перелік органів стандартизації 3 зазначенням їх компетенції [222, с. 184]. На нашу думку, суб’єктний склад у сфері стандартизації слід розглядати 3 позиції участі їх у процесах чи діяльності зі стандартизації, незалежно від форми власності та належності їх до різних 
категорій (видів) суб'єктів господарювання, державних органів та громадян. До таких ми відносимо органи та установи держави (органи місцевого самоврядування), що створюють стандарти чи інші вимоги стандартизації.

Залежно від повноважень вони поділяються на:

- органи влади, що формують політику у сфері стандартизації;

- органи влади, що реалізують політику у сфері стандартизації;

- національний орган стандартизації з організаційними функціями.

Органи державної влади здійснюють такі повноваження у визначених cфepax:

1) забезпечення нормативно-правового регулювання у сфері стандартизації;

2) визначення пріоритетних напрямів розвитку у сфері стандартизації;

3) інформування та надання роз'яснень щодо реалізації державної політики у сфері стандартизації;

4) узагальнення практики застосування законодавства у сфері стандартизації, розроблення пропозицій щодо його вдосконалення та внесення на розгляд в установленому порядку проектів законодавчих актів, актів Президента України, Кабінету Міністрів України;

5) погодження програми робіт з національної стандартизації;

6) інші повноваження згідно із законами.

Органи місцевого самоврядування в межах своїх владних повноважень вирішують багато питань у сфері стандартизації (ст. 26 Закону України «Про місцеве самоврядування в Україні»). Зокрема, встановлюють вимоги у сфері місцевої забудови, торгівлі, благоустрою, відходів та інші. Такі вимоги формально закріплюються у регуляторних актах, що можуть повністю чи частково відтворювати стандарти, кодекси усталеної практики, ТУ iз встановленням до суб'єктів господарської діяльності умов щодо проведення безпосередньо та/чи за допомогою третіх осіб обов'язкових погоджень, аналізів, експертиз, обстежень, випробувань тощо. Одночасно законодавство України забороняє приймати регуляторні чи інші акти органів місцевого самоврядування у 
сфері стандартизації, що можуть поширюватися за межі визначеної території громади. Зазвичай органи місцевого самоврядування є такими, що реалізують політику у сфері стандартизації, але їм можуть бути делеговані інші повноваження органів державної влади щодо формування такої політики.

Вважаємо, що відносини, які породжують органи державної влади та місцевого самоврядування у сфері стандартизації, можна відносити до організаційно-господарських, а акти регулювання таких органів в означеній сфері впливають на обмежене коло суб'єктів господарської діяльності. У разі видання актів органом державної влади коло обмежується сферою (напрямами діяльності), а у разі видання актів органом місцевого самоврядування територією.

Наступним суб’єктом у сфері стандартизації $є$ Національний орган стандартизації. До 03.01.2015 p. національним органом стандартизації було Мінекономрозвитку, але на сьогодні функції національного органу стандартизації виконує ДП, що не підлягає приватизації, утворене центральним органом виконавчої влади, що реалізує державну політику у сфері стандартизації (ст. 11 Закону України «Про стандартизацію», Розпорядження Кабінету Міністрів України «Про визначення державного підприємства, яке виконує функції національного органу стандартизації» від 26.11.2014 p. № 1163-р). Ця установа має такі особливості формування та функціонування:

1) статут та зміни до нього затверджуються центральним органом виконавчої влади, що реалізує державну політику у сфері стандартизації;

2) не може мати на меті одержання прибутку від своєї діяльності;

3) може виконувати обов'язки секретаріату технічних комітетів стандартизації;

4) має Керівну раду, що є дорадчо-наглядовим органом національного органу стандартизації та формується на паритетних засадах з представників, що працюють на громадських засадах;

5) рішення не є остаточними і можуть оспорюватися в Комісії з апеляцій, 
склад та порядок розгляду апеляцій якої затверджує також центральний орган виконавчої влади, що забезпечує формування державної політики у сфері стандартизації.

Національний орган стандартизації має широке коло повноважень (ч. 2 ст. 11 Закону України «Про стандартизацію»). Вважаємо, що нині доцільно звести (звузити) роль цього органу до суто організаційно-розпорядницького, залишивши повноваження:

1) участі у міжнародній стандартизації та забезпечення реалізації цього напряму у національному правовому (чи позаправовому) полі;

2) підготовки та затвердження програми робіт із національної стандартизації;

3) прийняття рішень щодо створення та припинення діяльності технічних комітетів стандартизації, визначення сфери їх діяльності;

4) координації діяльності технічних комітетів стандартизації;

5) забезпечення та сприяння співробітництву у сфері стандартизації між виробниками, постачальниками, споживачами продукції i відповідними державними органами;

6) заохочення суб'єктів малого та середнього підприємництва до участі в розробленні національних стандартів і кодексів усталеної практики, забезпечення доступу зазначених суб’єктів до текстів таких документів.

Установами, що виконують прикладну роботу зі стандартизації, є ТС зі стандартизації. Такі комітети є формою співробітництва заінтересованих суб’єктів господарювання, державних органів і громадян з метою організації та виконання робіт з міжнародної, регіональної, національної стандартизації у визначених сферах діяльності за закріпленими об’єктами стандартизації. По суті, ці установи підпадають під категорію непідприємницьких організацій без набуття статусу юридичної особи. На початок 2016 р. діяло 159 комітетів [256].

Основою діяльності технічних комітетів у сфері стандартизації є:

- фаховість учасників (працівників) комітету у тій сфері, якою відає комітет. Саме тому до роботи в технічних комітетах стандартизації залучаються 
уповноважені представники органів виконавчої влади, інших державних органів, органів місцевого самоврядування, суб'єктів господарювання та їх громадських об'єднань, організацій роботодавців та їх об’єднань, наукових установ і навчальних закладів, науково-технічних та інженерних товариств (спілок), громадських організацій споживачів (об'єднань споживачів), інших громадських об’єднань, професійних спілок, провідних науковців і фахівців;

- добровільність членства;

- формування за принципом врахування інтересів усіх осіб (сторін), що не виключає існування переважної більшості членів у того чи іншого суб'єкта, який заінтересований у прийнятті вигідного рішення;

- застосування принципу поширення знань (надання коментарів та роз'яснень положень національних стандартів, кодексів усталеної практики тощо);

- неприбутковість діяльності;

- прикладний характер діяльності та виконання повноважень у певній сфері.

Вбачається, що саме рівень ТС має бути основним, а тому визначальними суб'єктами стандартизації мають стати саморегулівні організації у сфері господарської діяльності, що можуть прирівнюватися чи ототожнюватися 3 такими комітетами.

Відсутність ТС стандартизації, сфера діяльності якого поширюється на певні об'єкти стандартизації чи сфери виробництва (надання послуг), не є перепоною для здійснення упорядкування та регулювання діяльності у визначеній сфері. Таку прогалину заповнюють робочі групи, що утворюються національним органом стандартизації, до складу яких входять представники заінтересованих сторін. Наприклад, наказом МО3 України від 12.05.2016 p. № 437 було затверджено персональний склад мультидисциплінарних робочих груп 3 розроблення медичних стандартів (уніфікованих клінічних протоколів) медичної допомоги на засадах доказової медицини, наказом ДП «УкрНДНЦ» від 17.04.2015 p. № 31 було створено робочу групу з розроблення проектів основоположних 
національних стандартів національної системи стандартизації, наказом Міносвіти від 11.10 .2007 р. № 897 було створено робочі групи з розроблення галузевих стандартів вищої освіти. Саме робоча група розробляє міжнародні, регіональні, національні стандарти та кодекси усталеної практики на відповідні об'єкти стандартизації, а національний орган стандартизації у такій ситуації лише погоджує, проводить перевірку, переглядає, розробляє зміни до національних стандартів і кодексів усталеної практики, а також приймає рішення щодо їх скасування чи відновлення дії.

ТC (i робочі групи) в окремих сферах стандартизації виступають, з одного боку, представниками суб'єктів, заінтересованих у створенні національних (регіональних, галузевих) вимог стандартизації, а з іншого - $є$ частиною системи державних органів стандартизації, оскільки їх діяльність забезпечується національним органом стандартизації, який часто виступає секретаріатом такого комітету або виконує інші організаційні функції.

Іншою формою роботи зі стандартизації та формалізації іiі вимог у нормативно-технічних документах є власна діяльність суб'єктів господарювання та органів без участі держави. Законодавство України надає можливість суб’єктам у відповідних сферах діяльності та 3 урахуванням своїх господарських i професійних потреб організовувати та виконувати роботи із стандартизації (ст. 16 Закону України «Про стандартизацію»), зокрема:

1) розробляти, приймати, перевіряти, переглядати та скасовувати стандарти, кодекси усталеної практики, ТУ і зміни до них, установлювати процедури їх розроблення, прийняття, перевірки, перегляду, скасування та застосування;

2) застосовувати прийняті ними стандарти, ТУ тощо;

3) брати участь у роботі спеціалізованих міжнародних і регіональних організацій стандартизації відповідно до положень про такі організації;

4) створювати та вести фонди нормативних документів і видавати каталоги нормативних документів для забезпечення своєї діяльності та інформаційного обміну; 
5) видавати і поширювати прийняті ними стандарти, кодекси усталеної практики та ТУ, документи відповідних спеціалізованих міжнародних організацій стандартизації, членами яких вони є чи 3 якими співпрацюють на підставі положень про такі організації або відповідних договорів.

Суб’єкти господарювання, що розробили та впроваджують стандарти, кодекси усталеної практики та ТУ, видали каталоги, набувають права власності на них (ч. 3 ст. 16 Закону України «Про стандартизацію»), у тому числі права інтелектуальної власності. На нашу думку, ці права можуть (у деяких випадках - повинні) передаватися разом із іншими подібними правами. Наприклад, при продажу прав на промисловий зразок продаються також права на використання стандартів чи інших нормативно-технічних документів підприємства, що застосовуються саме для цього типу виробів, про що має бути прямо зазначено у договорі.

Залежно від рівня та значення суб'єкта господарювання в обраній галузі виробництва товарів (надання послуг) суб’єктів стандартизації можна розділити на:

1) головні (основні, провідні) організації;

2) базові (відокремлені) організації;

3) відділи (бюро, управління, сектори) в складі суб’єкта.

Головними організаціями є самостійні науково-дослідні чи проектноконструкторські, технологічні організації, які виконують найважливіші роботи зі стандартизації продукції, процесів, послуг, що відповідають їх профілю [244, с. 28]. Ці установи здійснюють науково-методичне керівництво і координацію робіт відомчих базових організацій зі стандартизації, готують експертизу проектів нормативно-технічних документів до затвердження. До їх функцій може входити вивчення науково-технічного рівня продукції та послуг, які виробляють і надають в Україні та за кордоном, перевірка та перегляд чинних нормативно-технічних документів. Окремо на головні організації можуть покладати внутрішній (незалежний) контроль за впровадженням і використанням нормативно-технічних документів. 
Базові організації провадять роботи зі стандартизації певної групи товарів і послуг. Це також можуть бути науково-дослідні, проектно-конструкторські організації (спілки), фабрики та заводи, але менш значущі, ніж головні [226, с. 35 36]. Вони можуть входити до складу головних організацій. Базові організації розробляють основні напрями розвитку стандартизації закріпленої за ними групи продукції та послуг, проекти нормативно-технічних документів на конкретний вид продукції, процес чи послуги, здійснюють перевірку технологічних розробок, експертизу нових товарів і послуг 3 метою визначення рівня уніфікації та взаємозамінності тощо. Наприклад, у 2010 р. Кабінет Міністрів України затвердив Положення про базову організацію $з$ науково-технічної діяльності у будівництві (Постанова від 14.07.2010 р. № 589). Для отримання статусу базової організації науково-дослідна або науково-технічна (проектна) організація, подаючи до Мінрегіону заяву за встановленою формою, і повинна відповідати таким вимогам:

1) бути атестованою відповідно до Положення про державну атестацію науково-дослідних (науково-технічних) установ, затвердженого Постановою Кабінету Міністрів України від 07.04.1998 р. № 469;

2) мати науково-технічний і кадровий потенціал, дослідну базу;

3) розробляти протягом десяти років нормативні документи;

4) мати ТС (підкомітет) зі стандартизації (відповідно до закону).

У складі окремих суб'єктів господарювання, зазвичай, створено відділи зі стандартизації (спеціальні бюро, сектори тощо), основним завданням яких $є$ науково-технічне й організаційно-методичне управління роботами зі стандартизації на підприємстві, а також безпосередня участь у виконанні цих робіт. Наприклад, 3 1993 р. до 2015 р. в структурі Укргеодезкартографії діяв відділ стандартизації географічних назв [187].

Відділи зі стандартизації $€$ самостійними підрозділами, що підпорядковуються безпосередньо керівництву підприємства. Начальник такого відділу нарівні з керівником підприємства несе відповідальність за додержання вимог стандартизації, їх техніко-економічне обгрунтування, якість і відповідність 
показників нормативно-технічних документів сучасному рівню науки і техніки. До основних функціональних обов'язків відділів стандартизації на підприємствах, зазвичай, належать: 1) систематичний контроль за впровадженням і дотриманням нормативно-технічних документів; забезпечення відділів, цехів, лабораторій тощо необхідними нормативно-технічними документами та інформацією щодо змін у них; 2) контроль якості продукції; 3) забезпечення єдності та точності вимірювань тощо [90].

На нашу думку, слід зняти обмеження видів вимог стандартизації, що можуть розроблятися суб’єктами господарювання, та надати їм можливість називати нормативно-технічні документи у сфері стандартизації не лише стандартами, кодексами усталеної практики і ТУ, тим більше, що їх застосування є добровільним.

Суб'єкти, щуо здійснюють господарську діяльність та використовують стандарти чи інші вимоги стандартизаџії. Застосування вимог стандартизації суб'єктами господарювання, що виробляють товари (надають послуги), може здійснюватися в обов'язковому та добровільному порядку. ГК України чітко визначає тих суб'єктів (та окремі умови), що мають використовувати стандарти, кодекси усталеної практики чи їх окремі положення в обов'язковому порядку, це:

1) суб'єкти господарської діяльності, що діють у тих сферах діяльності, де обов'язковість застосування стандартів чи кодексів усталеної практики установлено нормативно-правовими актами;

2) учасники угоди (контракту) щодо розроблення, виготовлення чи постачання продукції, якщо в ній (ньому) $є$ посилання на певні стандарти чи кодекси усталеної практики;

3) виробник чи постачальник продукції, якщо він склав декларацію про відповідність продукції певним стандартам чи застосував позначення цих стандартів у іiі маркуванні;

4) виробник чи постачальник продукції на експорт, якщо угодою (контрактом) визначено вимоги, відмінні від тих, що встановлені технічними 
регламентами України, але обов'язкові для виконання. Одночасно такі положення угоди (контракту) перевіряються на відповідність законодавству України в частині вимог до процесу виготовлення продукції, iї зберігання та транспортування на території України.

Інші суб'єкти господарської діяльності мають дотримуватися загальних вимог до виробництва товарів (надання послуг), здійснювати статутну діяльність та не порушувати ті обмеження, що встановлюються державою при здійсненні певних видів господарської діяльності, що потребують ліцензування, тощо. Так, у сфері освіти за допомогою ліцензування державою підтримуються ті навчальні заклади, які відповідають ліцензійним вимогам, тобто спроможні надавати якісні послуги у сфері освіти. За допомогою призупинення дії або анулювання ліцензії, застосування органом ліцензування штрафних санкцій до навчальних закладів, послуги яких не відповідають вимогам, порушники стимулюються до свідомої зміни своєї поведінки [49, с. 171-172].

Недотримання вимог стандартизації або їх невиконання спричиняє негативні наслідки для суб'єкта господарської діяльності, що можуть мати і неправовий характер (втрата ринків збуту, репутації, зниження рівня споживання товарів чи послуг, зменшення доходів). На нашу думку, норми про обов'язкову відповідність товарів (послуг) задекларованим стандартам, кодексам усталеної практики чи їх окремим положенням, що зафіксовані у абз. 3 ч. 2 ст. 15 ГК України, мають поширюватися на вимоги інших нормативнотехнічних документів. Тобто будь-які задекларовані вимоги стандартизації переходять до рівеня обов'язкових (імперативних), що тягне за собою відповідні наслідки.

Суб'єкти, що підтверджують відповідність товарів (послуг) стандартам чи іншим вимогам стандартизації. Оцінка відповідності може здійснюватися при застосуванні добровільних чи обов'язкових нормативно-технічних документів. У разі добровільного застосування вимог стандартизації суб'єктом господарської діяльності орган з оцінки відповідності (у тому числі призначений орган чи 
визнана незалежна організація) залучається до здійснення добровільного підтвердження відповідності на договірних умовах.

Незалежно від суб'єкта звернення та обов'язковості (добровільності) застосовуваних вимог стандартизації суб'єктами оцінки та підтвердження відповідності (ч. 4 ст. 25 Закону України «Про технічні регламенти та оцінку відповідності») є:

1) визнані незалежні організації чи акредитовані випробувальні лабораторії;

2) призначувані органи чи установи держави (органів місцевого самоврядування).

Визнані незалежні організації мають відповідати таким ознакам (ч. 2 ст. 26 Закону України «Про технічні регламенти та оцінку відповідності»):

1. Наявність статусу юридичної особи - резидента України, незалежно від форми власності.

2. Персонал цього суб’єкта господарської діяльності, який виконує нерознімні з'єднання, та/або персонал, який проводить неруйнівний контроль, повинен протягом останніх трьох рр. мати досвід виконання робіт з оцінки відповідності (атестації) технології виконання нерознімних з'єднань.

3. Суб'єкт господарської діяльності має укласти договір обов'язкового страхування професійної відповідальності за шкоду, що може бути заподіяна третім особам.

4. Відповідність спеціальним вимогам до визнаних незалежних організацій, які визначені у технічному регламенті щодо обладнання, що працює під тиском, а в разі якщо такі вимоги не визначені у зазначеному технічному регламенті спеціальним вимогам до призначених органів, установленим Кабінетом Міністрів України.

Поряд 3 ознаками визнані незалежні організації мають такі особливості діяльності:

а) надання статусу здійснюється шляхом прийняття органом, що призначає, рішень про призначення визнаних незалежних організацій на здійснення оцінки 
відповідності технології виконання нерознімних з'єднань, персоналу, який виконує нерознімні з'єднання, та/або персоналу, який проводить неруйнівний контроль, згідно із зазначеним технічним регламентом;

б) їм не присвоюються ідентифікаційні номери;

в) можуть набувати статусу призначеного органу.

На відміну від визнаних незалежних організацій акредитована випробувальна лабораторія, зазвичай, $є$ невід'ємною частиною суб'єкта господарської діяльності, що здійснює виробництво товарів чи надає послуги, та не може набувати статусу призначеного органу (ч. 2 ст. 27 Закону України «Про технічні регламенти та оцінку відповідності»). Вона використовується для здійснення діяльності з оцінки відповідності для підприємства, частиною якого вона є, з метою виконання окремих процедур оцінки відповідності, визначених у відповідних технічних регламентах.

Особливостями діяльності випробувальних лабораторій є:

- відокремленість та відносна самостійність в управлінні (випробувальна лабораторія та іï персонал повинні мати визначене місце в організаційній структурі та використовувати такі методи звітування в межах підприємства, частиною якого $\epsilon$ зазначена випробувальна лабораторія, які забезпечують їх неупередженість і демонструють цю неупередженість відповідному національному органу з акредитаціі);

- iі співробітники не повинні брати участі в розробленні, виробництві, постачанні, встановленні, використанні або обслуговуванні продукції, яку оцінюють (випробувальна лабораторія та ії персонал не повинні займатися будьякою діяльністю, яка могла б суперечити незалежності їх суджень або їх доброчесності стосовно діяльності з оцінки відповідності);

- наявність акредитації в Україні (надання акредитації національним органом України з акредитації або національним органом з акредитації іншої держави);

- надання послуг виключно суб'єкту господарської діяльності, що здійснює виробництво товарів чи надає послуги та невід’ємною частиною якого вона $є$. 
Призначувані органи чи установи держави (органів місцевого самоврядування) є суб'єктами господарської діяльності як третьої сторони, яка доводить, що забезпечується необхідна впевненість у тому, що ідентифікована продукція, процес або послуга належним чином відповідає конкретному нормативно-технічному документу (ст. 32 Закону України «Про технічні регламенти та оцінку відповідності»). У цій процедурі призначувані органи $\epsilon$ незалежними від виробника (продавця, виконавця) і споживача (покупця) суб'єктами господарської діяльності, які засвідчують в письмовій формі, що продукція відповідає встановленим вимогам.

Особливостями діяльності таких органів є: 1) незалежна участь у процедурах оцінки та підтвердження відповідності третіх осіб; 2) наявність чіткої та суворої процедури у законодавстві України чи інших держав; 3) широке коло застосування процедури і діяльності таких органів.

Призначувані органи поділяються на три категорії:

- з сертифікації в державній системі сертифікації (станом на 11.08.2016 року діє 133 органи) [197];

- з сертифікації систем управління в державній системі сертифікації (станом на 11.08.2016 року діє 66 органів) [198];

- 3 оцінки відповідності вимогам технічних регламентів (станом на 11.08.2016 року діє 110 органів) [199].

Вимогами до призначених органів $\epsilon$ [185]:

1. Незалежність від особи, що надає об'єкт оцінки відповідності, та від особи, що заінтересована в такому об'єкті як споживач чи користувач.

2. Він не повинен бути проектувальником, виробником, імпортером, розповсюджувачем, монтажником, покупцем, власником, користувачем чи відповідальним за обслуговування продукції, яку він оцінює, або представником будь-якої з цих осіб. Зазначена вимога не виключає можливості використання оцінюваної продукції, яка є необхідною для роботи органу з оцінки відповідності, чи використання такої продукції для власних потреб. 
3. Він не повинен брати безпосередньої участі у проектуванні, виготовленні, реалізації, монтажі, використанні чи обслуговуванні продукції, яку він оцінює, або представляти сторони, що беруть участь у такій діяльності. Такий орган не повинен провадити будь-яку діяльність, яка може вплинути на незалежність його суджень або його доброчесність стосовно діяльності з оцінки відповідності, на провадження якої він призначається або призначений. Така вимога, зокрема, стосується послуг з консультування.

4. Здійснення нагляду за дотриманням субпідрядниками або дочірніми підприємствами, які ним залучаються до виконання робіт з оцінки відповідності, вимог щодо конфіденційності інформації, об’єктивності і неупередженості діяльності з оцінки відповідності такого органу.

5. Провадження діяльності з оцінки відповідності належним чином та із забезпеченням технічної компетентності, не піддаватися будь-якому тиску та спонуканню, зокрема фінансового характеру, які можуть впливати на його судження або результати його діяльності з оцінки відповідності, особливо з боку осіб чи груп осіб, заінтересованих у результатах такої діяльності.

6. Здатність виконувати всі завдання з оцінки відповідності, покладені на нього згідно з відповідними технічними регламентами та стосовно яких він призначається чи був призначений, незалежно від того, чи такі завдання виконуються безпосередньо органом 3 оцінки відповідності, чи такий орган $є$ відповідальним за їх виконання.

7. За умови доведення незалежності та відсутності будь-якого конфлікту інтересів може вважатися третьою стороною орган з оцінки відповідності, який $є$ членом об'єднання підприємців, що представляє суб'єктів господарювання та/або громадян - підприємців, які беруть участь у проектуванні, виготовленні, реалізації, монтажі, використанні чи обслуговуванні продукції, яку він оцінює.

8. Участь у відповідній діяльності із стандартизації. У разі коли орган 3 оцінки відповідності не бере участі в такій діяльності, він забезпечує 
інформування свого персоналу, відповідального за виконання завдань 3 оцінки відповідності, про таку діяльність;

9. Брати участь у відповідній діяльності секторальної чи міжсекторальної групи (груп) призначених органів з оцінки відповідності, утвореної (утворених) згідно з відповідним технічним регламентом (у разі утворення), забезпечувати інформування свого персоналу, відповідального за виконання завдань 3 оцінки відповідності, про таку діяльність, а також застосовувати документи, підготовлені за результатами роботи зазначеної групи (груп), як загальні настанови.

На нашу думку, в сучасних умовах в Україні дуже складно забезпечити об’єктивну оцінку відповідності та прослідковувати відсутність (наявність) зв'язків із заінтересованими особами. Тому знову стверджуємо, що при регулюванні таких відносин мають включатися позаправові механізми.

Суб’єкти, що здійснюють контроль за дотриманням стандартів чи інших вимог стандартизації, забезпечують припинення та попередження порушень стандартів, технічних вимог, інших нормативно-технічних документів, випуску продукції з порушенням вимог стандартів, підвищення рівня законності в галузі стандартизації. Суб'єкти господарської діяльності за порушення обов'язкових вимог стандартизації несуть відповідальність згідно з чинним законодавством України (ст. 10, 12 Закону України «Про стандартизацію», ст. 46, 47 Закону України «Про технічні регламенти та оцінку відповідності», розд. 5, ст. 44 Закону України «Про державний ринковий нагляд і контроль нехарчової продукції») або за власними зобов'язаннями, що випливають 3 договорів або позадоговірних відносин, про що йшлося вище. В основу контролю покладено відповідність продукції, товарів, послуг, що перевіряються, усім параметрам, нормам, характеристикам, вимогам, які встановлені у нормативно-технічних документах у стадії виробництва чи обороту, тобто на різних стадіях життєвого циклу (ст. 4 Закону України «Про державний ринковий нагляд i контроль нехарчової продукції»). Для оцінки якості та відповідності об’єктів контролю використовують види та методи, передбачені стандартами, ТУ, іншими нормативно-технічними документами. 
Контроль можна поділити на (за суб'єктами, що його здійснюють):

- власний (здійснюють або ініціюють самі суб'єкти господарської діяльності на власному виробництві чи в місці надання послуг);

- державний (здійснюють або ініціюють органи державної влади та/чи місцевого самоврядування);

- зовнішній (за ініціативою третіх осіб, у тому числі громадян споживачів), який здійснюють органи державної влади та/чи місцевого самоврядування або суб'єкти господарської діяльності.

Власний контроль суб'єкти господарської діяльності на власному виробництві чи в місці надання послуг здійснюють за допомогою акредитованих лабораторій та/чи інших підрозділів внутрішнього контролю. Він здійснюється на підставі нормативно-технічних документів та/чи локальних актів, про які йшлося в підрозділі 2.2 цієї роботи (щодо внутрішньогосподарських відносин та їх регулювання за допомогою вимог стандартизації).

Державний контроль відповідності продукції вимогам технічних регламентів здійснюється шляхом державного ринкового нагляду і контролю нехарчової продукції, а в разі якщо певні види продукції, на які поширюється дія технічних регламентів, не підлягають державному ринковому нагляду і контролю нехарчової продукції, - шляхом здійснення інших видів державного нагляду (контролю) відповідно до законодавства України (ст. 46 Закону України «Про технічні регламенти та оцінку відповідності», ст. 8 Закону України «Про державний ринковий нагляд і контроль нехарчової продукції», ст. 11 Закону України «Про загальну безпечність нехарчової продукції»). Така діяльність традиційно тлумачиться як вид адміністративної діяльності органів державної влади та/чи місцевого самоврядування [31; 148]. Водночас Н. В. Никитченко доводить, що діяльність таких органів, що прописується у кожному конкретному законі, визначає їх компетенцію у сфері господарської діяльності та надає їм можливість приймати відповідні рішення [142, с. 232]. Ми погоджуємося 3 такою думкою і вважаємо, що державний контроль за дотриманням (виконанням) вимог 
стандартизації є частиною господарського права i має відокремлюватися від поняття адміністративного контролю.

Державний контроль є невід’ємним атрибутом ринкової економіки. Саме завдяки йому запобігаються порушення i свавілля в економіці. Але і самі контролюючі органи та посадові особи не повинні допускати порушень i зловживань своїми повноваженнями. Якщо по відношенню до суб'єктів господарювання діє принцип «дозволено усе, що не заборонено законом», то по відношенню до державних контролерів застосовується принцип «дозволено лише те, що прямо дозволено законом», який підтверджує у них наявність виключної компетенції [51, с. 101].

3 іншого боку, держава забезпечує своїм громадянам захист їх інтересів як споживачів, надає можливість вільного вибору товарів (робіт, послуг), набуття знань і кваліфікації, необхідних для прийняття самостійних рішень під час придбання та використання товарів (робіт, послуг) відповідно до їх потреб [169, с. 149-150], і гарантує придбання або одержання іншими законними способами товарів (робіт, послуг) в обсягах, що забезпечують рівень споживання, достатній для підтримання здоров'я і життєдіяльності (ст. 3, 16, 42, 50 Конституції України, ст. 5 Закону України «Про захист прав споживачів»). Це надає споживачам право контролю за якістю та відповідністю товарів (послуг) вимогам стандартизації (ст. 25 Закону України «Про захист прав споживачів»), а також інші права на:

- державний захист своїх прав;

- гарантований рівень споживання;

- належну якість товарів (робіт, послуг);

- безпеку товарів (робіт, послуг);

- необхідну, доступну та достовірну інформацію про кількість, якість і асортимент товарів (робіт, послуг);

- відшкодування збитків, завданих товарами (роботами, послугами) неналежної якості, а також шкоди, заподіяної небезпечними для життя та здоров’я людей товарами (роботами, послугами), у випадках, передбачених законом; 
- звернення до суду та інших уповноважених органів влади за захистом порушених прав або законних інтересів;

- об’єднання на добровільній основі у громадські організації споживачів (об’єднання споживачів).

На нашу думку, на сьогодні найдієвішим є зовнішній незалежний контроль. Слід лише проаналізувати ТВ-контент, що пропонує оцінку відповідності та/чи контроль за дотриманням вимог стандартизації. Наприклад, телепередачі «Знак якості», «Життя без обману», «Добрий знак» мають успіх, оскільки оцінюють якість продуктів і речей, які купують пересічні споживачі (усі програми заявляють, що створені виключно в інтересах споживачів). Тобто коли є попит на «незалежний» зовнішній контроль, то є й така пропозиція. 3 точки зору права такий попит на інформацію стосовно якості товарів (послуг) та/чи дотримання вимог їх виробництва (надання), перевезення не є приводом для застосування заходів впливу на недобросовісних суб'єктів господарської діяльності чи для заохочення добросовісних. Хоча у разі порушення конкурентного законодавства та застосування методів незаконного отримання переваг на ринку держава (чи інший суб'єкт контролю) має негайно реагувати та з допомогою правових засобів втручатися у такий інформаційний потік.

У цілому права споживачів, механізм реалізації захисту цих прав та відносини між споживачами товарів (робіт, послуг) і виробниками (виконавцями, продавцями) регулюються Законом України «Про захист прав споживачів» та іншими законодавчими актами. На нашу думку, споживач у розумінні Закону України «Про захист прав споживачів» як учасник господарських відносин, пов'язаних із стандартизацією та дотриманням іï вимог, є слабкою стороною. Його права повсюдно порушуються шляхом:

I. Недостовірного маркування. Наприклад, на сьогодні в Україні вимоги до маркування харчової продукції встановлені у Законі України «Про безпечність та якість харчових продуктів» і Технічному регламенті щодо правил маркування харчових продуктів. Інформаційна частина маркування повинна відповідати 
«принципу Три Д» (достовірність, доступність, достатність) і не повинна вводити в оману стосовно характеристик продукту, зокрема його природи, ідентичності, властивостей, стану, складу, кількості, часових характеристик придатності тощо. Іноді на маркуванні визначають інформацію про властивості продукту, яких у нього немає.

II. Недотримання вимог при виготовленні товарів (наданні послуг). Сьогодні можливості харчової промисловості величезні. Можна придати деякі властивості продукту, не використовуючи потрібну для цього сировину, лише замінюючи іiі, наприклад, ароматизаторами, барвниками, комплексними добавками тощо. При цьому назва іноді не відображає реальної картини того, що це вже зовсім інший продукт. I лише у випадку, коли виробник все ж зазначив цю інформацію у складі продукту, це можна помітити [16]. Наведену ситуацію можна розцінювати як введення в оману споживача стосовно характеристики харчового продукту.

III. Прихованого обману. Наприклад, у ДСТУ 4427:2005 чітко передбачено, що для унеможливлення фальсифікування ковбас традиційного асортименту заборонено присвоювати новим видам ковбас традиційні назви, а також використовувати їх назви 3 додаванням окремих слів (наприклад, «Нова», «Екстра», «Прима», «Люкс» тощо) [59]. Так, до традиційного асортименту відносять загальновідомі назви ковбас, які виготовляли за державними та міждержавними стандартами СРСР.

\section{4 Особливості господарсько-правової відповідальності за} невиконання (недотримання) вимог стандартизації при здійсненні господарської діяльності в Україні

Зазвичай покладання на суб'єктів прав та обов'язків із допомогою регулюючих норм надає можливість отримати бажану поведінку. У такому разі 
говорять про достатній рівень правової культури та правової свідомості. У разі не спрацювання цих засобів правового регулювання складаються відносини, що є охоронними $[2$, с. $23 ; 200$, с. 90]. Зміст охоронних відносин відображається через юридичну відповідальність.

Юридичну відповідальність необхідно досліджувати у взаємозв'язку із соціальною. Тим більше, що в якості обов'язкового елемента механізму правового регулювання за допомогою стандартизації виступає правова культура та правосвідомість, що є більше проявом моралі і соціальності, аніж права. Це пов'язується 3 тим, що філософи та соціологи, даючи визначення соціальної відповідальності, відображають ті ії риси, що пов'язані з моральною, політичною, релігійною відповідальністю, не повністю при цьому відображають ознаки юридичної відповідальності. О. Плахотний вважає, що поняття відповідальності поєднує дві форми, а тому і два різних види відповідальності: 1) відповідальність як реакція суспільства на поведінку індивіда (суспільна відповідальність); 2) відповідальність як система відповідей індивіда на вимоги суспільства (особиста відповідальність). Він особливо підкреслює, що між суспільством та індивідом існує взаємозв'язок. 3 одного боку, суспільство покладає на індивіда обов'язок вчиняти соціально корисні вчинки, а з іншого - воно зобов'язане сприяти суб'єкту у здійсненні ним своїх прав та обов'язків і несе за це відповідальність [162, с. 4648]. Разом із тим досить обгрунтованою вважаємо класифікацію соціальної відповідальності на неправову та правову. Неправова соціальна відповідальність не має юридичного характеру та виступає у формі моральної, політичної, корпоративної, релігійної, етичної тощо [123, с. 442]. Правова ж відповідальність настає у випадку порушення норм державно-організованого права та має на меті захист права, інтересів громадян, суспільства, держави [283, с. 449; 239, с. 262-263; 19 , с. $9-10 ; 157$, с. $22 ; 237$, с. $155-156 ; 254$, с. 30$]$. Вона носить активний характер, оскільки передбачає активний психологічний вплив на порушника аж до застосування примусового фізичного впливу. Якщо ж вести мову про відповідальність за невиконання вимог стандартизації як засобу правового 
регулювання господарської діяльності, то вона $є$ багатоаспектним явищем i потребує не меншої уваги, ніж юридична відповідальність у цілому [71, с. 25; 266, c. 40].

Природа інституту юридичної відповідальності має правовий характер i полягає у застосуванні до винної особи, яка скоїла правопорушення, засобів публічно-правового примусу, передбачених санкцією порушеної норми у чітко визначеному процесуальному порядку [121, с. 177-178; 237, с. 159; 269, с. 10]. Це самостійний правовий інститут, що є основою охоронних правовідносин.

3 іншого боку, основною підставою господарсько-правової відповідальності учасника господарських відносин $\epsilon$ вчинене ним правопорушення у сфері господарювання [40, с. 601; 48]. Тобто суб’єкт господарювання чи будь-який учасник відносин у сфері господарювання, що постраждав від дій чи бездіяльності свого контрагента чи іншого порушника, не зобов'язаний доводити його вину. Порушник і так в силу закону та/або договору нестиме відповідальність. Господарська відповідальність настає незалежно від наявності вини правопорушника. Проте у випадку виключення законом чи договором може бути встановлена відповідальність за вину [40, с. 604]. Проте це скоріше буде додаткова, більш жорстка відповідальність.

Інколи висловлюється думка, що відповідальність у господарському праві це обов'язок суб'єктів господарювання відповісти за порушення, що складається з трьох обов'язків: законодавчого, нормативного та договірного [103, с. 278-279; 115 , с. $134-135 ; 246$, с. $148 ; 65$, с. $43 ; 238$, с. $207 ; 24$, с. $3 ; 38$, с. 111$] .3$ такою тезою слід не погодитися, оскільки має йтися не лише про відповідальність за порушення, а й про відновлення прав, можливість зупинення діяльності суб'єкта господарської діяльності тощо.

Виходячи із зазначеного, можемо дати таке визначення господарської відповідальності за невиконання (недотримання) вимог стандартизації - це обов'язок особи, винної у невиконанні (недотриманні) вимог стандартизації, зазнати передбачені правовою нормою чи договором наслідки особистого чи 
майнового характеру 3 метою припинення порушення, охорони суспільного порядку та забезпечення відновлення порушених прав. Крім того, господарська відповідальність за невиконання (недотримання) вимог стандартизації $є$ самостійним різновидом державно-примусових заходів. Цій відповідальності притаманні певні риси.

1. Як будь-яка соціальна, так і юридична відповідальність $є$ засобом гарантування й охорони суспільних відносин, у даному випадку з питання виконання (недотримання) вимог стандартизації. Коли йдеться про господарську діяльність, то відповідно до своєї мети (виготовлення та реалізація продукції, виконання робіт чи надання послуг вартісного характеру, що мають цінову визначеність) вона має засновуватися на вимогах стандартизації та регулюватися 3 допомогою її вимог, невиконання (недотримання) яких тягне за собою наслідки (інколи державний примус).

2. Вона встановлюється суб'єктами та гарантується певними засобами. Держава нарівні з іншими суб'єктами господарської діяльності визначає вимоги стандартизації, невиконання (недотримання) яких призводить до застосування процедур відповідальності.

3. $€$ засобом гарантування прав окремих суб'єктів та/чи суспільних інтересів, а невідворотність відповідальності стає запорукою виконання (дотримання) суб'єктами господарської діяльності вимог стандартизації з метою охорони життя та здоров'я людини, довкілля тощо.

4. $€$ елементом надбудови суспільства, що залежить від рівня розвитку економічних, політичних і суспільних відносин, а також свідчить про відкритість та свободу господарської діяльності. Це надає можливість, застосовуючи принцип добровільності стандартизації, не застосовувати елементи відповідальності до добросовісних суб’єктів господарської діяльності.

5. Має динамічний характер, тобто розвивається та трансформується разом із суспільними відносинами, виникненням нових технологій, методів і способів виробництва товарів чи надання послуг. Створення нових нормативно-технічних 
документів чи оновлення існуючих тягне за собою вдосконалення процедур застосування юридичної відповідальності.

6. Існує у сфері стандартизації та регламентується певним різновидом норм, у тому числі соціальних. Саме господарська сфера допускає найширше використання для регулювання не лише легальні нормативно-технічні документи, а й ті, що передбачені діловими кодексами, практиками ведення бізнесу та іншими не правовими документами, які все ж формують підстави для відповідальності за їх порушення. Інколи ці підстави можуть переводитися і в легальне поле (інколи шляхом закріплення у господарських договорах);

7. Переслідує досягнення певної мети та має функціональну спрямованість. Так, покладання юридичної відповідальності за невиконання (недотримання) вимог стандартизації при здійсненні господарської діяльності припиняє суспільно небезпечні дії, що можуть призвести (як мінімум) до обману споживачів або (як максимум) створення загрози для життя людини;

8. Передбачає настання певних наслідків для порушника навіть при застосуванні добровільних вимог стандартизації, оскільки дотримання цих вимог є обов'язком суб'єкта господарської діяльності, невиконання якого тягне за собою настання юридичної відповідальності.

9. Забезпечує системність розвитку суспільства як соціального утворення, оскільки вимоги стандартизації встановлюються для задоволення інтересів і потреб суспільства. Покладання відповідальності за невиконання (недотримання) цих вимог є проявом системності та послідовності.

10. Виробляє повагу до прав і свобод людини та $є$ проявом культури суспільства. Коли суб'єкт господарської діяльності добросовісно виконує вимоги стандартизації, пам'ятаючи про невідворотність настання відповідальності, то він виказує повагу до права споживача чи іншої заінтересованої особи на якісні та відповідні вимогам товари і послуги.

Господарсько-правова відповідальність за невиконання (недотримання) вимог стандартизації настає лише за наявності відповідних підстав. Розрізняють 
юридичні та фактичні підстави господарсько-правової відповідальності. Юридичні підстави - це правовий документ, що характеризує певну поведінку суб'єкта господарювання як протиправну і передбачає за неї форму та розмір відповідальності: такими підставами в господарському праві є закон і договір. Фактичні підстави - це ті життєві ситуації, що характеризуються законом або договором як неправомірні. Такі ситуації іменуються складом господарського правопорушення [28, с. 387-388]. Можна розділити два різновиди складів господарських правопорушень у сфері стандартизації: 1) недотримання (антагоніст дотримання, тобто необхідності точно, без відхилень виконувати, здійснювати що-небудь обіцяне, загадане, необхідне тощо; йдеться про імперативність дотримання вимог нормативно-технічних документів із стандартизації, а будь-яке порушення чи невиконання однісї 3 таких вимог спричиняє недотримання); 2) невиконання (нездійснення чого-небудь, тобто йдеться про диспозитивність, свободу вибору та наявність варіантів поведінки при виконанні вимог нормативно-технічних документів із стандартизації). Невиконання чи недотримання вимог нормативно-технічних документів із стандартизації однаково спричиняють негативні наслідки, а можливість розрізняти ці два поняття лише дає змогу визначитися з набором інструментів, за допомогою яких буде доведено (чи ні) необхідність застосування юридичної відповідальності. Так само від характеру вимог нормативно-технічних документів із стандартизації (добровільність чи обов'язковість) залежить доказова база, що надає можливість довести наявність (відсутність) причинно-наслідкових зв'язків при застосуванні процедур юридичної відповідальності.

Принципи господарсько-правової відповідальності за невиконання (недотримання) вимог стандартизації - це положення й ідеї, що мають законодавче закріплення та визначають самостійний i реальний характер відповідальності за невиконання (недотримання) вимог стандартизації як засобу гарантування й охорони об'єктивного та суб'єктивного права, суспільного порядку. Господарсько-правова відповідальність за невиконання 
(недотримання) вимог стандартизації базується на принципах, відображених у ст. 216 ГК України.

Законодавством можуть установлюватися межі господарсько-правової відповідальності за невиконання (недотримання) вимог стандартизації 3 двох причин: 1) коли йдеться про економічну складову господарської діяльності, що має на меті захист майнових інтересів учасників господарських правовідносин; 2) коли ставиться питання про безпекову складову господарської діяльності (часто розмір встановлених законом санкцій безпосередньо не пов'язується 3 розміром збитків (шкоди), завданих неправомірною поведінкою учасника господарських правовідносин, що зумовлено необхідністю захисту публічних інтересів у разі, якщо конкретний розмір завданої шкоди встановити неможливо чи наслідки неправомірної поведінки можуть настати в майбутньому).

На нашу думку, при застосуванні господарської відповідальності у сфері стандартизації звільнення від такої відповідальності суб’єкта господарської діяльності може застосовуватися лише під гарантії держави про забезпечення безпекової складової. Так, у разі підтоплення підприємства внаслідок паводка держава бере на себе зобов'язання знешкодити відходи або запобігти їх потраплянню у водні ресурси та здійснити контроль за здійсненням цим підприємством протипаводкових заходів на майбутнє.

\section{Висновки до розділу 3}

Господарська діяльність - предмет правового регулювання за допомогою стандартизації, який характеризується як суспільно-корисна діяльність суб'єктів господарювання щодо виробництва продукції, виконання робіт, надання послуг 3 метою їх реалізації як за плату, так і без плати. Вона грунтується на поєднанні 
приватних і публічних інтересів, здійснюється професійно на основі органічного поєднання державного регулювання (3 метою соціального спрямування економіки) та саморегулювання (з метою задоволення інтересів суб'єкта господарської діяльності) .

Стандартизація при регулюванні господарських відносин виступає як метод регулювання науково-технічного прогресу та його впливу на суспільство та довкілля, як спосіб ведення (вид) господарської діяльності та засіб організації суспільного господарства. У цьому значенні стандартизація виокремлюється від інших засобів регулювання господарської діяльності такими ознаками:

1) сферою здійснення є суспільне виробництво, тобто господарська сфера, що потребує вимог організаційного характеру та побудови системи адміністративного управління на основі міжнародних чи інших стандартів;

2) виробництво та реалізація продукції, виконання робіт, надання послуг відбувається не для власних потреб виробника, а для задоволення потреб інших осіб - споживачів у широкому розумінні, а тому застосовуються загальні та/чи спеціальні обов'язкові та/чи добровільні вимоги стандартизації;

3) функціонування продукції та послуг у формі товару на ринку має здійснюватися на підставі підтверджуючих документів про відповідність обов'язковим вимогам стандартизації;

4) професійність здійснення господарської діяльності на загальних засадах ведення бізнесу з використанням усталених кодексів (стандартизованих правил) щодо певної сфери господарської діяльності тощо;

5) спеціальний суб'єкт повинен, зазвичай, мати статус суб'єкта господарської діяльності, до якого держава пред'являє специфічні вимоги щодо державної реєстрації в загальному та/або спеціальному порядку;

6) поєднання приватних інтересів виробника товару чи надавача послуг та публічних інтересів забезпечує існування конкуренції, що засновується на застосуванні інших вимог, ніж у конкурента, або вимог, що надають можливість покращити якість товару (послуги) на кілька пунктів; 
7) значний рівень державного (у тому числі нормативно-технічного) регулювання зумовлено необхідністю захистити суспільство, значні його верстви (насамперед споживачів) та довкілля від зловживань 3 боку підприємців, які вдаються до несумлінної поведінки 3 метою зменшення своїх видатків та отримання найбільших прибутків.

Суб’єкти господарювання та інші учасники відносин стандартизації у сфері господарювання здійснюють свою діяльність у межах встановленого правового господарського порядку, який грунтується на вказаних положеннях Конституції України, визначається ГК України та іншими нормативно-правовими актами господарського законодавства. Діючу систему господарського законодавства зазвичай поділяють на загальні норми та щодо окремих видів продукції чи послуг (беручи за основу поділу предмет регулювання). Так само можна виділяти загальні норми господарського законодавства, що регулюють стандартизацію, та спеціальне законодавство, що регулює стандартизацію окремих товарів, послуг чи видів господарської діяльності у конкретно визначеній сфері.

При регулюванні господарської діяльності за допомогою стандартизації ми можемо говорити про застосування дозвільного типу регулювання щодо принципу свободи діяльності господарюючих суб'єктів, а імперативного - при випуску продукції чи наданні послуг лише у межах норм нормативно-технічних документів. По суті, як і в інших публічно-приватних галузях права в господарському праві застосовується змішаний тип правового регулювання.

Стандартизація в господарському праві має свою специфічну конструкцію та єдині принципи для застосування усіх вимог стандартизації:

1) норми і вимоги стандартизації забезпечують усі сфери господарської діяльності, встановлюючи рівні вимоги для виготовлення окремих типів чи видів товарів, надання типових послуг;

2) свобода підприємницької діяльності може обмежуватися вимогами щодо безпеки товарів (послуг) для людини чи довкілля, а може забезпечуватися шляхом добросовісного виконання вимог; 
3) адаптація вимог національної стандартизації до світових норм технічного регулювання забезпечує вільний рух товарів (послуг) на внутрішньому та зовнішніх ринках;

4) втручання держави дозволяється як оптимальне державне регулювання, оскільки ступінь державного регулювання залежить від стану економіки, внутрішнього та зовнішнього становища країни (більш значний за кризового стану економіки, стихійного лиха та інших негараздів, а послаблий - у разі стабільного стану економіки);

5) захист національного товаровиробника досягається впровадженням новітніх норм і вимог у максимально стислі терміни або шляхом адаптації вимог міжнародних стандартів, директив тощо;

6) втручання держави $є$ доцільним, обгрунтованим та законним лише у тому разі, якщо господарська діяльність створює загрозу життю та здоров’ю громадян, довкіллю чи національній безпеці.

Господарські правовідносини $є$ засобом переведення загальних розпоряджень юридичних норм у площину суб'єктивних прав і обов'язків, що може мати форму господарського чи іншого виду договору при застосуванні норм правил та вимог у сфері стандартизації.

Організаційно-господарські відносини виникають, як правило, у сфері господарського управління. Також ці відносини можуть виникати 3 приводу підтвердження відповідності товарів та/чи послуг вимогам нормативно-правових документів зі стандартизації. Внутрішньогосподарськими $\epsilon$ відносини, що складаються між структурними підрозділами суб'єкта господарської діяльності, та його відносини з власними структурними підрозділами (ч. 7 ст. 3 ГК України). Від правової культури та правової свідомості фізичних осіб, що створюють для суб’єктів господарської діяльності локальні акти, залежить створення такої системи локальних норм права, що має адекватно відображати умови економічної, виробничої і технологічної діяльності цього суб'єкта. Для досягнення мети правового регулювання господарської діяльності, внутрішньогосподарські відносини суб'єктів господарської діяльності мають засновуватися на ДСТУ 1.4-93. 
Врахування вимог нормативно-технічних документів зі стандартизації в договірних відносинах суб’єктів господарської діяльності в Україні допомагає перетворити загальні норми об'єктивного права (чи позаправових норм) у конкретизовані суб'єктивні права і обов'язки, що може мати форму господарського договору. Договір має сприяти покращенню виробництва, поширенню товарів та послуг, нівелюванню ринкових бар'єрів з підвищенням якості та відповідальності сторін. Тому стандартизація $є$ необхідним та обов'язковим складником договорів для здійснення господарської діяльності та при її здійсненні.

Для господарських відносин стандартизація виступає у двох якостях: 1) як основа регулювання (створення норми права чи локального нормативноправового акта); 2) як засіб регулювання. Нормативно-технічні документи зі стандартизації систем управління виступають зовнішньою формою норм (вимог) та способів організації та здійснення управлінської діяльності.

Стандартизація надає додаткових гарантій учасникам господарських відносин та допомагає реалізовувати свої правомочності. Суб’єктами стандартизації як засобу регулювання господарської діяльності можна називати фізичних та/чи юридичних осіб, що здійснюють діяльність із встановлення та/чи застосування вимог стандартизації, у тому числі технічного регулювання та оцінки відповідності. Стандартизація при реалізації правомочностей суб'єктами господарських відносин виступає основним засобом регулювання, оскільки є нормою для застосування та критерієм оцінки відповідності.

У разі неспрацювання регулятивної функції засобів правового регулювання складаються відносини, що $\epsilon$ охоронними. Зміст охоронних відносин відображається через юридичну відповідальність. Господарська відповідальність за невиконання (недотримання) вимог стандартизації - це обов'язок особи, винної у невиконанні (недотриманні) вимог стандартизації, зазнати передбачені правовою нормою чи договором наслідки особистого чи майнового характеру 3 метою припинення порушення, охорони суспільного порядку та забезпечення відновлення порушених прав. Крім того, господарська відповідальність за 
невиконання (недотримання) вимог стандартизації $є$ самостійним різновидом державно-примусових заходів.

Сутність такої відповідальності полягає в тому, що склад господарського правопорушення залежить від форми такої відповідальності. Якщо йдеться про відшкодування збитків, то склад правопорушення включає чотири елементи (умови відповідальності):

1) протиправну поведінку - тобто таку поведінку господарюючого суб’єкта, що суперечить вимогам закону або договору;

2) наявність збитків - втрати або пошкодження майна, зайвих (додаткових) витрат суб'єкта господарювання і неотриманого прибутку (якщо закон не забороняє його стягувати). При цьому необхідно довести не лише наявність збитків, а й їх розмір;

3) причинний зв’язок між протиправною поведінкою і завданими збитками: при цьому враховується лише необхідний (а не випадковий) причинний зв'язок;

4) вину - в господарському праві про її наявність свідчать два елементи: а) наявність у суб'єкта господарських відносин реальної можливості діяти правомірно і попередити настання негативних наслідків (збитків) і б) неприйняття ним усіх необхідних заходів щодо недопущення протиправної поведінки і попередження настання збитків.

Види порушень та підстави покладання господарської відповідальності у сфері стандартизації чітко описані у законодавстві України або мають передбачатися у договірних зобов'язаннях. Можна виділити два типи складів правопорушень: 1) недотримання добровільних вимог нормативно-технічних документів із стандартизації; 2) невиконання обов'язкових вимог нормативно-технічних документів iз стандартизації. Межами, що встановлюються при покладенні юридичної відповідальності за невиконання вимог стандартизації, $\epsilon$ розмір відшкодування, строки настання відповідальності та інші межі, що можуть встановлюватися договірними зобов'язаннями чи нормативно-технічними документами. 


\title{
РОЗДІЛ 4 \\ МІЖНАРОДНИЙ ДОСВІД РЕГУЛЮВАННЯ ВІДНОСИН 3 ДОПОМОГОЮ СТАНДАРТИЗАЦЇ̈
}

\author{
4.1 Правовий режим діяльності Міжнародної організації стандартизації, \\ Європейського комітету зі стандартизації та їх роль в усуненні бар’єрів у \\ торгівлі
}

Загальновідомо, що ISO є колегіальним органом та об'єднує 163 країни. Стандарти впливають приблизно на $80 \%$ світової торгівлі товарами. Ті країни, що не є повноправними та активними членами ISO, дозволяють іншим вирішувати, як встановлювати стандарти та за яких умов буде здійснюватися міжнародна торгівля. Членство в ISO включає права та переваги, якими слід активно користуватися, належну практику та обов'язки, яких слід дотримуватися, а також вдосконалення системи ISO та надання пропозицій глобальним клієнтам ISO [95, c. 5-6]. ISO та іiї члени також пов'язані юридичними зобов'язаннями 3 питань конкуренції чи антимонопольних правопорушень, захисту персональних даних та авторських прав.

Члени ISO є провідними організаціями стандартизації у своїх країнах, і в кожній країні є лише один член. Кожен учасник представляє ISO у своїй країні. Приватні громадяни/піддані або компанії не можуть стати членами ISO. Iснує три категорії учасників, що мають різний рівень доступу та впливу на систему ISO. Це допомагає ISO бути інклюзивною організацією, одночасно визнаючи різні потреби та спроможність кожного національного органу стандартів.

Повні члени (чи органи-члени) впливають на розробку та впровадження стандартів ISO з безпосередньою участю та голосуванням на технічних та політичних засіданнях ISO. Повні учасники також продають та приймають 
міжнародні стандарти ISO на національному рівні.

Члени-кореспонденти стежать за розробкою стандартів та стратегій ICO, відвідують технічні та політичні зустрічі ISO як спостерігачі. Членикореспонденти можуть продавати та приймати міжнародні стандарти ISO на національному рівні.

Підписні илени можуть проглядати статус робіт зі стандартизації ISO, але не можуть брати участі у таких роботах. Вони не продають та/або не приймають міжнародні стандарти ISO на національному рівні.

Крім основного завдання з розробки, перегляду, голосування та публікації вимог у сфері стандартизації ISO розширює свою компетенцію стосовно:

1) надання допомоги для підвищення рівня обізнаності громадськості щодо стандартів та стандартизації. Йдеться про просвітницьку діяльність для підвищення рівня правової культури та правової свідомості кінцевого споживача;

2) співпраці з іншими організаціями, такими як МЕК та МСЕ. Стандарти, розроблені спільно ISO та MEK, мають назви вигляду ISO/IEC [222; 223];

3) щорічного звіту щодо стандартизації. Йдеться про перспективи розробки нових сфер чи напрямів стандартизації щодо проблем, 3 якими стикається сьогодні суспільство, а також оцінюється ефективність діючих стандартів;

4) залучення широкої громадськості через COPOLCO. Основним завданням COPOLCO є заохочення інтересу споживачів до стандартів. Робота здійснюється у двох напрямах:

- тренінги та заходи безпосередньо для споживачів, органів державної влади, виробників та експертів з стандартизації;

- семінари та тренінги для національних органів стандартизації 3 метою покращення залучення зацікавлених сторін, включаючи споживачів.

Як видно, COPOLCO розрізняє орган стандартизації, що відповідає за стандартизацію в конкретній країні, та зацікавлені сторони. Громадяни (піддані) та колективні суб'єкти (у тому числі держава) відносяться COPOLCO до сторін, що прямо не беруть участі у стандартизації, але мають свій інтерес: громадяни - 
як кінцеві споживачі продукції та послуг, суб'єкти господарської діяльності - для задоволення мети своєї діяльності та отримання прибутку, держава - як гарант дотримання суспільного устрою та безпеки, експерти зі стандартизації - як учасники, що працюють 3 готовими стандартами, оцінюючи їх відповідність чи невідповідність тим чи іншим критеріям.

ISO подає перелік напрямів, що має цікавити споживачів та суб'єктів господарської діяльності, які бажають залучити їх ширше коло та отримати доступ до міжнародних ринків: 1) соціальна відповідальність - ISO 26000: 2010; 2) задоволення потреб клієнтів та подання скарг ISO 10001: 2007, ISO 10002: 2004, ISO 10003: 2007, ISO 10004: 2012, ISO 10008: 2013; 3) відкликання споживчих товарів ISO 10393: 2013; 4) безпека споживачів продукції ISO 10377: 2013; 5) платіжна система послуг через мережі ISO 14452: 2012; 6) мобільні фінансові послуги ISO 22222: 2005, усі частини ISO 12812: 2017 [287, с. 2-3].

Здійснюючи свою діяльність, ISO засновується на таких принципах:

1. Відповідності чутливості ринку. ISO не вирішує, коли слід розробляти новий стандарт, але відповідає на запит від промисловості або інших зацікавлених сторін, таких як групи споживачів. Як правило, галузевий сектор чи група повідомляють про необхідність стандартизації для свого національного члена, який потім зв'язується з ISO.

2. Глобальності експертних думок. Стандарти ISO розробляються групами експертів 3 усього світу, які $є$ частиною більшої групи, що називаються технічними комітетами. Ці експерти обговорюють всі аспекти стандарту, включаючи його обсяг, основні визначення та зміст.

3. Участі усіх зацікавлених сторін. ТС складаються 3 експертів 3 відповідної галузі, а також $з$ асоціацій споживачів, наукових кіл, неурядових організацій та урядів країн.

4. Консенсусу. Розробка стандартів ISO є підходом на основі консенсусу, де враховуються коментарі всіх зацікавлених сторін і не може існувати диктату одного чи кількох учасників. 
Враховуючи викладене, можна дійти висновку, що нині стратегію розвитку ISO формують завдання, що полягають не лише у створенні стандартів та їх поширенні, а й здійсненні соціальної, безпекової та просвітницької мети, що має полегшити міжнародну торгівлю. Паралельно з ISO функціонують регіональні та національні організації стандартизації, що співпрацюють 3 глобальною організацією, але формують основоположні вимоги для свого регіону 3 урахуванням національних традицій, усталених правил та інших соціальних засад суспільства у тому чи іншому об'єднанні. До них відносять такі: Міжскандинавська організація зі стандартизації, Євро-Азійська Рада зі стандартизації, метрології та сертифікації, Панамериканський комітет стандартів, Консультативний комітет зі стандартизації та якості країн-членів АCEAH, Конгрес по стандартизації країн Тихоокеанського басейну, Арабська організація 3 промислового розвитку та гірничої справи, Африканська регіональна організація по стандартизації. Перші дві організації діють в межах Європи, але на сьогодні на перше місце виходить CEN, що формує політику стандартизації Свропи.

CEN визнається $\mathrm{CC}$ як європейська організація стандартизації. Правовою

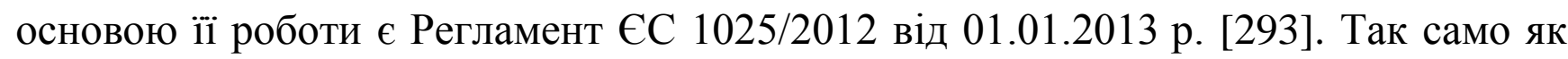
ISO, CEN об'єднує знання та експертизу своїх членів, бізнесу та промисловості, а також інших зацікавлених сторін з метою розробки EN для продуктів, матеріалів, послуг та процесів, що охоплюють найновіші технології.

Основні засади діяльності CEN:

1) створення EN, що забезпечуватимуть якість, продуктивність та оперативну сумісність;

2) сприяння захисту навколишнього середовища, а також забезпечення здоров'я та безпеки споживачів і працівників;

3) підтримка міжнародної системи стандартизації шляхом співпраці з ISO на основі Віденської угоди (як вже зазначалося вище).

Члени CEN є національними органами стандартизації 34 європейських країн, включаючи 28 країн СC, Македонію, Сербію, Туреччину та три країни EFTA 
(Ісландію, Норвегію та Швейцарію).

Система стандартизації в Європі базується на національних органах стандартизації членів CEN. Національний орган стандартизації $є$ єдиним інформаційним центром для всіх зацікавлених сторін та $є$ основним центром доступу до узгодженої системи, що включає регіональну (європейську) та міжнародну стандартизацію. Національні члени CEN відповідають за впровадження EN як національних стандартів. Національні органи стандартизації поширюють та продають реалізований EN і мають вилучати будь-які суперечливі національні стандарти. CEN, у свою чергу, працює зі своїми членами для розробки та визначення EN у відповідь на особливі потреби, які були визначені компаніями та іншими користувачами стандартів.

Як було зазначено, кожен національний орган стандартизації, який є частиною системи CEN, зобов'язаний прийняти кожен EN як національний стандарт і зробити його доступним для клієнтів у своїй країні. Таким чином, один EN стає національним стандартом у всіх 34 країнах CEN.

$\mathrm{CEN}$, так само як ISO, не виключає залучення неповних членів до своєї роботи зі статусом приєднання та супутника. Так, національні органи стандартизації тих країн, які офіційно визнані СС потенційними кандидатами на членство в СС, можуть стати партнерами CEN на умовах приєднання. Одним із критеріїв $\epsilon$ те, що вони повністю мають інтегрувати європейську систему стандартизації з метою досягнення технічної гармонізації в рамках єдиного європейського ринку та усунення бар'єрів у торгівлі. Ті, хто не має статусу приєднання чи не може поки його отримати з певних причин, запрошуються стати органами стандартизаиії супутника (CSB) CEN. Метою обох партнерств CEN є прийняття каталогу стандартів CEN як національного, а також суттєвий внесок у технічну роботу, що проводиться в технічних комітетах CEN.

Наслідком роботи в технічних комітетах CEN є створення EN на засадах консенсусу. Важливо зазначити, що використання стандартів є добровільним, а тому не існує юридичного зобов'язання щодо їх застосування. Близько 30\% EN, 
опублікованих CEN, були розроблені у відповідь на конкретні запити (мандати на стандартизацію), видані Європейською Комісією. Багато з цих стандартів відомі як «гармонізовані стандарти». Вони надають можливість підприємствам забезпечувати, щоб їхні товари або послуги відповідали основним вимогам, викладеним у європейському законодавстві (Директиві СС). У таких випадках можна сказати, що стандарт передбачає «презумпцію відповідності» основним вимогам законодавства.

Європейська стандартизація є ключовим інструментом консолідації єдиного ринку та полегшення транскордонної торгівлі в межах Європи, а також на світових ринках. Це цінний інструмент для підвищення конкурентоспроможності європейських компаній, яким створюються умови для економічного зростання суб'єктів господарської діяльності.

\section{2 Організаційно-правові засади стандартизації у деяких країнах Свропи}

На основі матеріалів з офіційних інтернет-сторінок урядів та/чи організацій стандартизації детальніше проаналізуємо та порівняємо поняття, зміст, суб'єктів стандартизації та іiї значення у країнах Свропи.

Стандартизація у країнах Європи має таке визначення:

1) в Австрії, Німеччині, Румунії - розробка юридично необов'язкових рекомендацій, розроблених фахівцями для вирішення міжгалузевих завдань в економіці та публічному секторі;

2) у Бельгії - процес створення на основі консенсусу угоди про продукт, послугу чи процес 3 визначенням конкретних їх характеристик (етапи: пропозиція, проект, відкритий запит, публікація);

3) у Бельгії, Хорватії, Кіпрі, Чехії, Данії, Естонії, Франції, Італії - діяльність iз встановлення положень для загального та багаторазового використання щодо 
фактичних або потенційних проблем, спрямованих на досягнення оптимального ступеня порядку. Ця діяльність включає розробку, прийняття, опублікування i застосування стандартів;

4) у Фінляндії - створення узгоджених способів для виробництва (створення) будь-чого;

5) у Греції - діяльність з підготовки, випуску та сприяння впровадженню і використанню національних стандартів і документів зі стандартизації;

6) в Угорщині - діяльність із упровадження загальних та повторюваних процесів та технічних рішень для модернізації виробництва та підвищення якості послуг;

7) у Люксембурзі - діяльність 3 розробки і забезпечення довідкових документів, які вирішують технічні та комерційні (економічні) проблеми продукції, товарів або послуг, для безперервного і безперешкодного застосування у сфері економіки, соціальній та технічній сфері, а також при проведенні наукових досліджень;

8) у Нідерландах - процес для реалізації стандарту, що $є$ відкритим, прозорим, здійсненим на основі консенсусу та проводиться в стандартних комітетах, що складаються з представників усіх зацікавлених сторін;

9) у Португалії - діяльність, що має організований характер та чітко визначену послідовність дій для розробки стандартів;

10) у Швейцарії - діяльність, що передбачає саморегулювання при створенні та впровадженні стандартів, а також $\epsilon$ засобом для боротьби 3 державною зарегульованістю. Основний лозунг «більше стандартів - менше законів».

Грунтуючись на міжнародних та європейських нормах, вказані вище країни однаково розуміють стандартизацію як одно- чи багатостадійну діяльність. У більшості країн наголошують також на наявності статичної та динамічної стадії стандартизації.

Доволі цікавим та таким, що потребує уваги, є визначення мети (завдань) стандартизації у країнах Європи: 
1. Практичне застосування нових знань для взаєморозуміння - Австрія, Бельгія, Кіпр, Чехія, Фінляндія, Німеччина, Сербія, Іспанія.

2. Підвищення конкурентоспроможності - Австрія, Бельгія, Данія, Франція, Угорщина, Ірландія, Італія, Мальта, Іспанія.

3. Освоєння нових ринків - Австрія, Кіпр, Франція, Італія, Португалія, Сербія, Іспанія.

4. Створення інновацій - Австрія, Кіпр, Німеччина, Греція, Нідерланди, Іспанія.

5. Служба громадським інтересам - Бельгія, Данія, Греція, Мальта.

6. Усунення бар'єрів у торгівлі - Бельгія, Чехія, Данія, Естонія, Фінляндія, Франція, Угорщина, Ірландія, Італія, Мальта, Португалія, Сербія, Іспанія.

7. Технічне співробітництво - Бельгія, Хорватія, Кіпр, Чехія, Данія, Естонія, Фінляндія, Франція, Угорщина, Італія, Нідерланди, Іспанія.

8. Забезпечення безпеки і благополуччя громадян - Бельгія, Хорватія, Данія, Естонія, Греція, Італія, Мальта, Нідерланди, Сербія, Іспанія.

9. Охорона довкілля - Бельгія, Хорватія, Данія, Естонія, Франція, Мальта, Нідерланди, Сербія, Іспанія.

10. Безпека та умови праці - Бельгія, Данія, Естонія, Нідерланди, Сербія.

11. Доступність до державної політики - Бельгія, Естонія, Іспанія.

12. Відповідність продукту, процесу чи послуги своїй меті - Хорватія, Естонія, Фінляндія, Мальта, Нідерланди, Сербія.

13. Забезпечення інтересів суспільства - Фінляндія, Греція, Італія, Мальта, Сербія, Іспанія.

14. Полегшення життя споживачів - Фінляндія, Греція, Мальта.

15. Підвищення рівня роботи організації (підприємства, установи) Франція, Португалія, Іспанія.

16. Обов’язкове викладення державною мовою - Греція.

17. Міжнародне визнання національних товарів та послуг - Угорщина, Португалія. 
18. Зниження витрат зацікавленої особи - Португалія.

19. Зменшення помилок при веденні бізнесу - Португалія, Іспанія.

20. Розробка серії технічних специфікацій, стандартів, які добровільно використовуються організаціями - Іспанія.

У иілому усі краӥни дотримуються позииії, що стандартизащія має здійснюватися для реалізації єдиної технічної політики у иій сфері, захисту інтересів споживачів $i$ держави, безпеки товарів $i$ послуг для життя, збереження майна та охорони довкілля. Діяльність, що здійснюється у сфері стандартизації, має засновуватися на основних засадах (принципах), що також неоднаково розуміється у різних країнах Європи:

1. Просування економіки - Австрія, Бельгія, Чехія, Фінляндія, Німеччина, Греція, Італія, Португалія, Іспанія.

2. Рівний доступ національних виробників до інших ринків - Австрія, Кіпр, Чехія, Іспанія.

3. Консенсус як засіб взаємодії різних систем - Австрія, Бельгія, Хорватія, Кіпр, Чехія, Естонія, Фінляндія, Німеччина, Греція, Італія, Португалія, Сербія, Іспанія.

4. Постійне оновлення - Австрія, Бельгія, Хорватія, Німеччина, Угорщина, Португалія, Іспанія.

5. Впровадження усталених ноу-хау - Австрія, Бельгія, Німеччина, Угорщина, Мальта.

6. Відкритість процесу (діяльності) - Хорватія, Кіпр, Чехія, Естонія, Угорщина.

7. Послідовність - Хорватія, Угорщина, Португалія.

8. Сумісність - Естонія, Фінляндія, Угорщина.

9. Взаємозамінність - Естонія, Фінляндія.

10. Уніфікація - Естонія, Фінляндія.

11. Задоволення потреб суб’єктів - Греція, Мальта, Сербія, Іспанія.

12. Безкорисливість (волонтерство) у сфері стандартизації - Угорщина. 
13. Неприбутковий характер національної стандартизації - Угорщина.

14. Прозорість та публічність - Угорщина, Італія, Мальта, Португалія, Сербія.

15. Спрощення процедур у торгівлі - Португалія.

Краӥни колишнього соитабору, щзо ще недалеко відійшли від засад стандартизаиії, яка здійснювалася у СРСР, так само, як $і$ Україна, до засад (принципів) обов'язково включають уніфікацію, взаємозамінність та сумісність. Водночас, країни, що початково засновувалися на міжнародних нормах у сфері стандартизаиї, на перше місие серед принщипів виносять сучасні аспекти стандартизації: торгівлю, усунення технічних бар'єрів та безпеку.

Принцип добровільності застосування стандартів діє в усіх країнах так, як закріплено у міжнародних нормах. Тобто всі вимоги, що не охоплені законодавством, є добровільними. Франція, Німеччина, Італія відносять добровільність навіть до засадничих принципів стандартизації. Досить цікавою $є$ позиція Австрії, Бельгії, Німеччини, Португалії та Македонії, коли обов’язковими вважають також вимоги, що прямо передбачені у договорі (контракті, угоді). Вони прирівнюються до законодавчих вимог і забезпечуються такими самими заходами для їх виконання.

Зазвичай у країнах Європи не здійснюють класифікацію документів (актів) у сфері стандартизації. Їх розрізняють лише за рівнями на:

- внутрішні (національні) стандарти - Австрія, Бельгія, Хорватія, Кіпр, Чехія, Естонія, Фінляндія, Македонія, Німеччина, Угорщина, Люксембург;

- європейські стандарти - Бельгія, Хорватія, Кіпр, Фінляндія, Македонія, Греція, Угорщина, Ірландія, Люксембург;

- регіональні стандарти - Естонія, Македонія, Мальта;

- міжнародні стандарти - Австрія, Бельгія, Хорватія, Кіпр, Чехія, Естонія, Фінляндія, Македонія, Німеччина, Греція, Угорщина, Ірландія, Люксембург, Мальта.

Діяльність зі стандартизації в країнах Свропи здійснюють усі зацікавлені особи (у широкому значенні). До них, зазвичай, відносять органи держави (у тому 
числі міжнародні та/чи регіональні органи), розробників стандартів, організації 3 оцінки відповідності. Окремі країни виділяють інших зацікавлених осіб: 1) представників бізнесу - Австрія, Бельгія, Кіпр, Чехія, Данія, Естонія, Македонія, Німеччина, Угорщина; 2) професійні організації - Австрія, Кіпр, Естонія, Німеччина, Угорщина; 3) науковців - Австрія, Кіпр, Данія, Швейцарія, Велика Британія, Німеччина; 4) споживачів - Естонія, Німеччина, Велика Британія, Франція.

Основними зацікавленими особами є суб'єкти господарської діяльності, оскільки стандартизація ніколи не є самоціллю, вона є основою для ланцюга зі створення доданої вартості, оптимізації та ефективного використання ресурсів. Участь у стандартизації забезпечує таких суб'єктів перевагами:

1. Отримання з перших рук знань про майбутні події та тенденції. Це надає компанії конкурентну часову перевагу на глобалізованих ринках.

2. Вплив на процес розробки стандартів, що надає можливість захистити свої інвестиції в продукти, дослідження і розробки. Громадські зацікавлені сторони можуть привернути увагу до захисту довкілля або питань споживачів.

3. Побудова мережі комітетів (організацій, груп) зі стандартизації є ідеальним місцем для зустрічі та встановлення нових контактів для обміну ідеями.

4. Розробка й обмін знаннями. Учасниками комітетів (організацій, груп) зі стандартизації є вузько спеціалізовані експерти, що нададуть інформацію «з перших рук».

Ще одним важливим питанням є розуміння співвідношення стандартів та технічних регламентів у досліджуваних країнах. Ще раз наголошуємо, що технічного регулювання як виду діяльності у Європі немає. Технічні регламенти, що входять до законодавчого поля, створюються на основі принципу «посилання на стандарти». Це означає, що технічні вимоги не включаються в технічні регламенти, але надаються посилання на стандарт, який встановлює такі вимоги, що надає можливість отримати такі переваги:

1) процес регулювання полегшується і прискорюється; 
2) технічний прогрес не вимагає внесення змін до нормативно-правових документів (лише до стандартів);

3) може бути полегшене усунення бар'єрів у торгівлі;

4) застосування технічних регламентів стає більш ефективним шляхом посилання на ідентичні, спільно визначені міжнародні стандарти, а відмінність між національними технічними регламентами різних країн нівелюються.

Посилання на стандарти (в нормативних документах) здійснюється шляхом вказання на один або кілька стандартів замість викладення їх детальних положень в рамках цього регулювання. Посилання може бути: а) датоване, без зазначення дати або загальне; б) одночасно виключне або індикативне; в) пов'язане з більш загальним правовим положенням, що стосується сучасних технологій або визнаних правил техніки, або бути самостійним.

До посилання на стандарти висуваються такі вимоги щодо точності (змісту):

1) з відсиланням (до стандартів) - посилання на стандарти, які ідентифікують один або кілька конкретних стандартів таким чином, що пізні зміни стандарту або стандартів не застосовуються, якщо тільки технічне регулювання не буде модифіковано (стандарт зазвичай ідентифікується за його номером і датою або виданням);

2) нестандартна довідка зі стандартів - посилання на стандарти, які ідентифікують один або кілька конкретних стандартів таким чином, що пізніші зміни стандарту або стандартів повинні застосовуватися без необхідності змінювати положення технічного регламенту (стандарт, як правило, визначається лише його номером);

3) загальна довідка про стандарт - посилання на стандарти, які позначають усі стандарти певного органу та/або певної сфери, не визначаючи їх окремо (у вигляді реферування);

4) виняткове відсилання до стандартів - посилання на стандарти, згідно 3 якими єдиним способом виконання відповідних вимог технічного регламенту є дотримання зазначених стандартів; 
5) орієнтовна довідка про стандарти - посилання на стандарти, де зазначено, що одним із способів дотримання відповідних вимог технічного регламенту є дотримання зазначених стандартів (виконання цього посилання $€$ формою положення, що вважається задоволеним при оцінці відповідності).

Обов'язковим стає лише той стандарт, застосування якого визначено на підставі загального закону або виняткового посилання в технічному регламенті, що зазначено також в ISO/IEC Guide 2:2004.

У підсумку можна зазначити, що європейські країни дозволяють i допомагають національним суб'єктам господарської діяльності використовувати стандартизацію в якості ефективного стратегічного інструменту. Наприклад, стандарти використовуються на ранній стадії розвитку, щоб підготувати ринок для нового продукту, а далі стандартизація допомагає формувати ринок, підвищує безпеку інвестицій, підтримує дерегулювання. Стандартизація допомагає полегшити законодавче навантаження на державу, коли законодавці можуть зосередитися на загальних питаннях безпеки, посилаючись на стандарти для технічних деталей. 3 іншого боку, як інструмент дерегулювання стандарти $є$ корисними для приватного сектора і споживачів шляхом їх захисту від надмірно жорстких законів з одночасним звільненням держави від відповідальності за складання докладних технічних вимог. У деяких країнах національним органом стандартизації є неурядова громадська організація, що досить ефективно здійснює свої функції, отримуючи вотум довіри від суб’єктів публічного та приватного права, надаючи можливість створити баланс між інструментами імперативного та диспозитивного регулювання відносин у сфері стандартизації. У Європі до таких країн відносяться: Угорщина, Данія, Ісландія, Ірландія, Норвегія, Польща, Іспанія, Швеція, Швейцарія, Велика Британія.

Як раціональний спосіб забезпечення дотримання правил стандарти допомагають стимулювати торгівлю на внутрішніх i зовнішніх ринках. Добровільні стандарти є однією з форм гнучкого саморегулювання для суб’єктів господарської діяльності і надають можливість усунути необхідність засобів 
державного регулювання, що мають тенденцію бути більш жорсткими і менш гнучкими. Стандартизація більшості продуктів і послуг в європейських країнах $\epsilon$ добровільним процесом, але деякі вимоги встановлюються законом через європейські директиви та національне законодавство. Зокрема: обов'язкові стандарти безпеки; стандарти, зазначені в нормативно-правових актах; стандарти гігієни їжі. Національні закони країн Свропи передбачають правові рамки і встановлюють завдання захисту та безпеки, у той час як створені на основі консенсусу стандарти детально описують способи досягнення цих цілей.

Економічні вигоди від стандартизації становлять близько 1-1,5\% валового внутрішнього продукту (ВВП). Такі результати були отримані при проведенні досліджень у ФРН, Австрії, Швейцарії, Італії асоціаціями зі стандартизації (DIN, ON, SNV і UNI відповідно) [289; 297]. Україні слід оцінити ці результати та врахувати, що стандартизація створює значну цінність для національної економіки.

\section{3 Саморегулівні засади стандартизації в Канаді та їі вплив на розвиток міжнародної стандартизації}

За 150 pp. існування Конфедерації Канади було пройдено значний шлях від упорядкування промислових робіт до глобалізаційних процесів, у тому числі усунення бар’єрів у торгівлі. До 1917 р. Канада використовувала стандартизацію та вимоги, що продукувала Велика Британія (відповідно до протекторату), але сталося так, що саме Велика Британія запропонувала Канаді утворити свій перший комітет зі стандартів для вирішення проблем «канадського походження»: обширність території, різноманітність промислового виробництва, екстремальні погодні умови тощо. Канадський комітет 3 технічних стандартів складався 3 добровольців, які пообіцяли запровадити порядок у промислових роботах, розробляючи стандарти на консенсусній основі, одночасно координуючись 3 
колегами з Великої Британії, США та інших країн-союзників. У 1919 році група отримала статут від федерального уряду для створення CESA. Tобто ияя організаџія створювалася як асоиіація бізнесу, щзо праџювала як неприбуткова організація, але виконувала функиії державного органу зі стандартизаиії.

Не гаючи часу, CESA випустив свій перший стандарт для сталевих залізничних мостів у 1920 році, що було зумовлено кількома трагічними випадками при заміні дерев'яних конструкцій на металеві. Інновації ведуть до стандартів, спрямованих на покращення громадського здоров'я в Канаді через пастеризацію молока, очищення стічних вод та очищення води. У перші дні появи електроенергії, CESA опублікував збірку електричних стандартів під назвою Канадський електричний кодекс (1927р.).

До Другої світової війни поступово важливими ставали системи управління якістю та стандарти для виготовлення механічних частин, засобів зв'язку, зброї та двигунів, оскільки з'являлися нові технології, що підтримувалися міжнародними стандартами. Сьогодні пріоритетом $є$ просування вищої освіти в галузі стандартизації та сталого туризму. У 2010 р. у Ванкувері проводилися зимові Олімпійські ігри, а стандартизація стала запорукою успіху та показником чистоти (чесності) Канади, оскільки Рада стандартів Канади допомагає забезпечити справедливу гру, акредитуючи тимчасову антидопінгову лабораторію Олімпіади за міжнародним стандартом з тестування та калібрування (ISO / IEC 17025: 2005). Можна стверджувати про стратегічну цінність стандартизації, коли приділясться особлива увага ролі стандартів у сферах соиіального та економічного розвитку.

У світі екологічних стандартів Канада та Рада стандартів Канади завжди були міжнародними лідерами. Канада 3 самого початку була секретаріатом для ISO/TC 207 - TC, який зосереджувався на розробці екологічних стандартів. У результаті зобов'язань Канади щодо виконання природоохоронних конвенцій Глобального саміту 1992 року, перше засідання для ISO/TC 207 відбулося в Торонто в 1993 році. 
Канада перша у світі випустила стандарт щодо психічного здоров'я працівників на робочому місці, оскільки за даними Комісії з питань психічного здоров'я Канади (МНСС) психічні захворювання в Канаді призводили до 35 мільйонів втрачених робочих днів щороку, що коштувало канадським підприємствам 198 мільярдів доларів втрат (у розрахунку 30 років) [286]. працівників психічно здоровими мало як соціальний, так і економічний сенс. Саме тому МНСС очолила роботи зі стандартизації у цій сфері та ввела в дію новий стандарт CAN/CSA-Z1003-13/BNQ 9700-803/2013 «Психологічне здоров'я та безпека на робочому місці. Запобігання, популяризація та керівництво для поетапної реалізації». Для роботодавців цей стандарт має стати відправною точкою для створення політики, навчальних програм та аудитів, що ставлять збереження психічного здоров'я першочерговим завданням при забезпеченні соціального пакету на робочому місці. Цей стандарт також допомагає роботодавцям визначати небезпеку для добробуту працівника, наприклад, стрес від надто багатьох вимог. Він також рекомендує, щоб працівники отримували повагу від керівництва та були винагороджені за їх добру роботу. Стандарт CAN/CSA-Z1003-13/BNQ 9700-803/2013 є безкоштовним при закачуванні з сайту CSA Group (необхідно лише вказати свої ідентифікаційні дані), що робить його доступним для компаній різного розміру. Цей національний стандарт був скачаний більш ніж 16000 разів протягом першого року, що свідчить про значний інтерес канадців до того, щоб мати надійний механізм вирішення проблем ризику психічного здоров'я на робочому місці [184]. У практиці Канади часто розробником стандарту є недержавна організація (у иьому випадку - CSA Group), але стандарт набуває чинності як національний (в позначенні ми бачимо «CAN/»). Стандарт є добровільним, але його застосування $є$ справою честі підприємств Канади, щчо забезпечує їм переваги не лище для працівників, а й для контрагентів та кінщевих споживачів.

Значення стандартизації для економіки Канади. Протягом 1990-х рр. тенденції глобалізації, екологічності та багатосторонності змусили країни по 
всьому світу вивчити їх місце у світовій економіці. При створенні COT у 1995 році наголошувалося на необхідності цього завдання та надихнуло багато країн відмовитися від національних стандартів та прийняти міжнародні стандарти, які сприяють вільній торгівлі та економічному розвитку. Як країна 3 економікою, орієнтованою на експорт, інтереси Канади були частиною цих міжнародних рухів. Важливо брати участь у розробці міжнародних стандартів у ключових галузях, щоб переконатися, що вони задовольняють потреби Канади. Щоб ефективно брати участьу міжнародній стандартизації, Канада створила план, який заохочував участь всіх зацікавлених сторін у канадських штатах, щоб керувати своїми процесами стандартизації в цих нових глобальних обставинах.

Канадська стратегія стандартів, опублікована у 2000 р., була однією 3 перших у світі стратегій національних стандартів. Ключові промислові держави світу, включаючи КНР, Францію, ФРН, Японію та США, продовжують розробляти власні стратегії стандартів за принципами, що розроблені та застосовуються в Канаді. Ними зокрема є:

1) створення та розуміння структури суб'єктів стандартизації з урахуванням інтересів зацікавлених сторін, до яких включили представників промисловості, уряду, неурядових організацій, організацій з розробки стандартів, органів з оцінки відповідності та інших осіб;

2) збільшення присутності (профілювання) Канади на міжнародному рівні, зокрема, у ISO та MEK;

3) підвищення обізнаності про те, як стандарти можуть впливати на економіку Канади;

4) визначення пріоритетності дії своїх (національних) стандартів у певних секторах економіки.

Стандартизація в Канаді визначається як розробка та застосування стандартів публікацій, які визначають прийняті практики, технічні вимоги та термінологію для товарів, послуг та систем. Бачимо такі основні ознаки:

- вид діяльності, що має дві складові; 
- результатом діяльності $є$ створення стандарту (пасивна фаза стандартизації);

- стандарт має застосовуватися (активна фаза стандартизації);

- підставою для здійснення стандартизації $є$ наявність загальноприйнятої практики, технічних новинок (проривів) та необхідність донести певну інформацію;

- об’єктами стандартизації є товари (послуги) та системи у широкому значенні, до яких відносять природні та технологічні системи, їх складові, різні види діяльності, що регулюють ці системи тощо.

Стандарти виступають інструментами (засобами) стандартизації та допомагають забезпечити кращі, безпечні та більш ефективні методи виробництва товарів та надання послуг, а також є важливими елементами технологій, інновацій та торгівлі.

Стандартизація є складовою частиною політики Канади, а тому одним із іiі завдань $є$ інформування всіх зацікавлених сторін, включаючи представників державних органів, про можливості використання стандартизації у сфері державної політики. Деякі урядові департаменти, наприклад промисловий (Industry Canada), вже усвідомили цю можливість і активно використовують системи стандартів у своїй діяльності. Крім того, до цього тематичного блоку входять такі пункти, як створення і підтримка структур, покликаних відстоювати інтереси країни на міжнародному рівні, впроваджувати системи управління якістю та охороною довкілля для досягнення відповідних цілей державної політики.

Діяльність 3 розробки стандартів нерозривно пов'язана 3 підтримкою сталого розвитку суспільства, охороною здоров'я населення, забезпеченням безпеки держави, соціальним забезпеченням працюючих i захистом прав споживачів. Канада особливо активно проводить залучення до діяльності зі стандартизації новітні чи такі, що розвиваються, галузі економіки. Часто у зацікавлених осіб (суб’єктів господарської діяльності у певній галузі) немає 
інформації про можливості, що виникають при проведенні робіт зі стандартизації та оцінки відповідності. Поліпшення обізнаності цих секторів про стандартизацію допоможе їм брати реальну участь у розробці нових стандартів, які надалі впливатимуть на їх роль i участь в ринкових відносинах. Центральну координуючу роль у таких процесах в Канаді відіграє Рада зі стандартизації, що збирає інформацію про потреби стандартизації в нових галузях і вивчає шляхи налагодження контактів та робочих домовленостей між суб'єктами.

Процес розробки стандартів в Канаді спеціалізований згідно 3 профілем відповідних промислових секторів. Національну систему стандартизації Канади задовольняє подібний підхід, що надає можливість стимулювати внесення відповідних пропозицій від суб'єктів господарської діяльності окремих галузей. Одночасно він надає змогу розраховувати на інтелектуальну i фінансову підтримку з боку цих суб’єктів.

Нині Канада нарощує зусилля зі збереження свого лідерства в розробці стандартів для електронної торгівлі на основі усунення технічних бар'єрів в торгівлі, що включає: рух у напрямі глобальної системи акредитації; доведення до зацікавлених сторін цілей і підходів, що лежать в основі угод про взаємне визнання; підтримку Угоди 3 внутрішньої торгівлі. Такий напрям визначає необхідність вдосконалення структури Web-сайту національної системи стандартизації Канади, а також ії метрологічної інфраструктури.

Громада Канади зі стандартизації складається зі складної мережі людей та організацій, залучених до розробки, просування та реалізації стандартів:

Окремими іiї учасниками визначаються:

1. Спожсивачі та неурядові організаиії (у тому числі суб'єкти господарської діяльності), що забезпечують врахування при стандартизації соціальних проблем, стану здоров'я населення, питань охорони довкілля, безпеку держави та конфіденційність. Йдеться про привнесення «людського елементу» до розробки стандартів та стратегій стандартизації, гарантуючи, що потреби та інтереси канадців будуть збалансовані при розробці та застосуванні стандартів. 
2. Уряди провінціій та територій у своїй діяльності опираються на мережу організацій Канади 3 питань стандартизації для сприяння обговоренню торговельних угод та підтримки досягнення їх мандатів та пріоритетів на національному та міжнародному рівнях. Уряди та їх установи сприяють підвищенню ефективності надання державних послуг своїм громадянам. Залучення до стандартизації представників уряду сприяє забезпеченню врахування інтересів усіх зацікавлених осіб та досягненню оптимального консенсусу між сторонами.

3. Експерти галузі надають важливі вузькоспеціалізовані висновки чи здійснюють технічну експертизу. Їх участь у стандартизації допомагає гарантувати, що стандарти та стратегії стандартизації корисні для бізнесу та збалансовують інтереси зацікавлених сторін. Суб’єкти господарської діяльності покладаються на стандарти та оцінку відповідності як на основу для розробки та продажу товарів на національному та глобальних ринках.

4. Рада стандартів Канади має повноваження від федерального уряду сприяти ефективній стандартизації:

- акредитує організації стандартизації, перевіряючи, чи мають вони ресурси, структури та експертизу для надання надійних високоякісних послуг;

- затверджує Національні стандарти Канади;

- представляє Канаду на ключових регіональних та міжнародних форумах зі стандартизації.

Рада стандартів Канади була заснована в 1970 р. 3 метою сприяння ефективній та добровільній стандартизації в Канаді. Рада через Міністра інновацій, науки та економічного розвитку Канади подає до парламенту пропозиції із вдосконалення законодавства у сфері стандартизації та здійснює нагляд за національною мережею стандартизації в Канаді. На основі аналізу тенденцій, пов'язаних зі стандартизацією, а також інформаційно-просвітницької діяльності та зацікавленості, що стратегічно спрямовані на ключові галузеві, урядові та споживчі зацікавлені сторони, Рада стандартів Канади здатна: 
1) надавати інформацію, яка допоможе зацікавленим сторонам встановити пріоритети та цілі стандартизації;

2) скласти рекомендації, що впливають на стандарти та аспекти, пов'язані 3 оцінкою відповідності торговельної та регуляторної політики;

3) визначити необхідні умови для Канади для оптимізації використання стандартизації;

4) забезпечити механізм підтримки оптимального здоров'я та безпеки канадців.

5. Органи оцінки відповідності забезпечують використання стандартів відповідно до їх цілей та достовірну оцінку товарів, систем та послуг відповідно до застосованих стандартів. До них належать калібрувальні та випробувальні лабораторії; сертифікатори персоналу, органи контролю, органи сертифікації систем управління, продуктів та послуг.

Організації з розробки стандартів у Канаді працюють 3 волонтерськими організаціями з усієї країни для розробки канадських стандартів та прийняття або адаптації міжнародних стандартів для використання в Канаді. Ці організації надають важливу технічну експертизу та відіграють вирішальну роль у забезпеченні того, щоб стандарти, які були введені в експлуатацію в Канаді, відповідали кліматичним, економічним, технологічним та соціальним умовам країни. Міжнародні та регіональні органи стандартизації працюють разом для глобальної гармонізації стандартів 3 метою лібералізації торгівлі, вирішення спільних суспільних проблем та захисту споживачів. Разом вони прагнуть до міжнародного визнання звітів про відповідність, результатів та використання загальних знаків, які можуть скоротити витрати та час, пов'язаний із багаторазовим випробуванням продуктів.

3 викладеного вище видно, що Канада покладає технічний та технологічний прогрес, розвиток технологій та інноваџії в основу сучасної стандартизації. Стандартизачія в Канаді не лише статично закріплює вимоги до об'єктів, а й передбачає динаміку - впровадження, використання, оиінку відповідності вимог використовуваним стандартам. До участі у стандартизації залучається широке 
коло осіб, у тому числі споживачі. Стандартизація також допомагає бізнесу та збалансовує інтереси зацікавлених сторін 3 метою лібералізації торгівлі, вирішення спільних суспільних проблем та захисту споживачів. Україні варто переймати подібні ініціативи.

\section{4 Пропозиції щодо вдосконалення національної правової системи України у сфері стандартизації}

Україна представлена у дев'яти міжнародних, європейських і регіональних організаціях зі стандартизації, метрології та сертифікації. Зокрема, Україна є повноправним членом ISO з 1993 р. та набула членства у CEN у 1997 р. в статусі члена-кореспондента (статус було передбачено спеціально для країн, що мають наміри інтегруватися до (C).

Відповідно до умов членства Україна може:

1) створити міцне партнерство, яке забезпечить певні сфери економіки привілейованою позицією на європейському ринку;

2) отримати необмежений доступ до EN для їх прийняття (адаптації);

3) пропонувати національним зацікавленим сторонам можливість стати частиною європейського процесу стандартизації та приєднуватися до провідних європейських галузей та компаній.

Основні переваги, що Україна має популяризувати для зацікавлених сторін:

1. Отримання прямого доступу до репозиторіїв стандартів CEN і CENELEC, що містять накопичену експертизу великої мережі CEN і CENELEC (понад 200000 експертів у своїй галузі з 34 країн).

2. 3'являється можливість сприяти технічному узгодженню, що допомагає зацікавленим особам вийти на ринок з 600 мільйонів споживачів та отримати додатковий прибуток. 
3. Стати спостерігачем у необмеженій кількості технічних органів та отримати шанс формувати майбутні $\mathrm{EN}$, відкривши для себе «двері» європейського єдиного ринку.

4. Брати участь у засіданнях Генеральної Асамблеї CEN та CENELEC як спостерігач. Отримувати інформацію 3 перших рук про стратегічні зміни в провідному економічному блоці.

Пропонуємо, засновуючись на європейських та міжнародних вимогах, будувати національну стандартизацію на таких засадах:

1. Стандарти є добровільними та вільними для використання. На відміну від законів, стандарти юридично не обов'язкові. Обов'язковими вони стають, якщо згадуються у договорах та/чи нормативно-правових актах.

2. Завданням стандартизації є підтримка законодавства України. Технічні регламенти мають містити посилання на стандарти, що спрощують систему i надають можливість зробити швидшим і автоматичним оновлення законодавства при оновленні стандартів;

3. Збалансування між вимогами, що визначають істотні вимоги щодо здоров'я людини, безпеки для довкілля та якості продукції, та саморегулюванням для суб'єкта господарської діяльності. Вони можуть вільно вибирати як виконувати обов'язкові вимоги та автоматично отримувати вигоду з презумпції відповідності для вільного доступу до європейського ринку.

4. Стандарти є корисними та ефективними при визначенні відповідальності. Навіть якщо стандарти прямо не названі в договорі або нормативно-правовому акті, вони можуть використовуватися для вирішення правових спорів, особливо в тих випадках, коли йдеться про відповідальність за якість продукції. Суди можуть використовувати стандарти, щоб вирішити, чи дійсно виробник слідував підтвердженим правилам i здійснив «належну обачність». Таким чином, стандарти можуть забезпечити правову визначеність при застосуванні заходів відповідальності;

5. Стандарти можуть допомогти споживачу чи іншій зацікавленій особі 
визначити, чи є продукт «безвідмовним». Технічні стандарти відіграють особливу роль у сфері господарського права, оскільки зацікавлені особи можуть використовувати їх, щоб допомогти визначити, чи $є$ продукт справним чи ні. Однак там, де використання стандарту не було обов'язковим, недотримання не обов'язково означає, що товар чи послуга є дефектними. Зрештою, продукти можуть бути виготовлені належно навіть там, де стандарти не застосовувалися, особливо у разі, коли їх використання є добровільним.

6. Стандарти мають забезпечити права сторін у договорі або кінцевого споживача на видалення несправності, доставку безвідмовного продукту або компенсації за будь-які збитки, що виникли через відсутність гарантованих характеристик. Стандарти можуть використовуватися як запобіжник при виявленні пошкодження та допомогти визначити суб'єкт відповідальності та розподілити збитки.

7. Здійснення популяризації значення стандартизації для суб’єктів господарської діяльності. Зокрема, говоримо про такі переваги: удосконалення своєї продукції та/чи послуг; залучення нових клієнтів; підвищення конкурентоспроможності; збільшення довіри до бізнесу; зменшення кількості помилок; зниження витрат на розвиток і інновації; гарантування сумісності своїх продуктів 3 іншими компонентами; полегшення укладання договорів та виконання зобов'язань; полегшення виходу на нові ринки; підвищення шансів на успіх у разі застосування стандартів всередині суб’єкта господарської діяльності.

У національному законодавстві слід врегулювати питання усунення технічних бар'єрів у торгівлі відповідно до умов міжнародних угод про членство України до СОТ, про асоціацію між Україною й СС, про вільну торгівлю 3 окремими країнами, а також забезпечити права та інтереси фізичних, юридичних осіб, органів державної влади і місцевого самоврядування та інших зацікавлених осіб. Дуже важливим $є$ удосконалення понятійно-термінологічного апарату нормативно-правових актів України. Вище ми вже зверталися до міжнародного термінологічного стандарту ISO/IEC Guide 2:1996 (Standardization and related 
activities - General vocabulary), до його оновленої редакції ISO/IEC Guide 2:2004 та до європейського термінологічного стандарту EN 45020:2006. У зазначених документах міститься офіційне автентичне тлумачення таких понять:

1) регламент - документ, який містить обов'язкові законодавчі правила, що приймається повноважним органом (варто зазначити, що у розумінні ст. 288 Договору про заснування $Є \mathrm{C}$ регламент є нормативно-правовим актом $€ \mathrm{C}$, що має бути загальнодоступним, повністю обов'язковим та безпосередньо застосовуватися в усіх державах-членах. Це визначення за своєю сутністю не суперечить EN 45020:2006);

2) технічний регламент - положення, яке містить технічні вимоги безпосередньо або шляхом включення посилання на вміст стандарту, технічної специфікації або кодексу практики (технічний регламент може бути доповнений технічними настановами та рекомендаціями, які викладаються через певні засоби з дотриманням вимог регламенту, а тому вважаються такими, що задовольняють положення);

3) стандартизація - діяльність із встановлення положень для загального і багаторазового використання, спрямована на досягнення оптимального ступеня порядку щодо фактичних або потенційних проблем.

Прослідковується розуміння стандартизації як організуючої активної діяльності у сфері впорядкування, а регламенти та технічні регламенти європейці розуміють як акти регулювання. Вбачається, що дослівний переклад «technical regulation» як «технічне регулювання» призвів до помилкового розуміння, що в Європі діє система технічного регулювання поряд із стандартизацією.

Вище вже йшлося про різницю між стандартизацією та законодавством за суб'єктним складом та формою вираження (закріплення). Слід також ще раз наголосити, що використання стандартів є добровільним, тоді як норми є обов'язковими та юридично закріпленими [179, с. 180]. Тобто стандартизація не така само, як законодавство, але містить його частину (технічні регламенти).

Нині поняття технічного регулювання в Україні вже введено у більше, ніж 500 нормативно-правових актів [177, с. 188-189], а тому слід чітко поставити 
акценти на співвідношенні стандартизації та технічного регулювання, закріплення та реалізації їх вимог 3 метою усунення технічних бар'єрів у торгівлі та забезпечення прав заінтересованих осіб у сфері стандартизації.

На основі викладеного слід внести такі зміни та доповнення:

1. До Закону України «Про стандартизацію»:

1.1. Статтю 1 доповнити новим поняттям «нормативно-технічний документ - документ, прийнятий уповноваженим на це суб'єктом нормотворення у визначеній законом формі та порядку, який встановлює правила, загальні принципи, технічні характеристики та/чи інші вимоги до різних видів діяльності або іï результатів (у тому числі товарів та послуг) та розрахований на неодноразове застосування. До нормативно-технічних документів належать національні стандарти, технічні та інші регламенти, кодекси усталеної практики (настанови, правила, зведення правил), ТУ, державні класифікатори, стандарти підприємств та інші документи, що містять вимоги до різних видів діяльності або iіi результатів (у тому числі товарів та послуг)».

1.2. У ст. 1 визначення поняття «стандартизація» викласти у такій редакції: «стандартизація - діяльність, що полягає в установленні та застосуванні положень для загального та неодноразового використання щодо наявних чи потенційних завдань і спрямована на досягнення оптимального ступеня впорядкованості в певній сфері суспільного життя для забезпечення мети стандартизації. Стандартизація включає в себе технічне регулювання та оцінку відповідності».

1.3. Частину 2 ст. 16 викласти у новій редакції та доповнити реченням: «2. Стандарти, кодекси усталеної практики, ТУ та інші нормативно-технічні документи, прийняті підприємствами, установами та організаціями, застосовуються на добровільній основі. Щодо цих нормативно-технічних документів діє презумпція відповідності результатів господарської діяльності вимогам стандартизації, що застосовуються в добровільному порядку, у разі заявлення (декларування) їх у маркуванні товарів (послуг) чи іншим способом.»

2. До Закону України «Про технічні регламенти та оцінку відповідності»: 
1.2. Абзац 36 ч. 1 ст. 1 доповнити реченням «Технічне регулювання $\epsilon$ частиною національної системи стандартизації».

2.2. Абзац 37 ч. 1 ст. 1 викласти у новій редакції: «технічний регламент нормативно-правовий акт, що містить технічні вимоги безпосередньо або шляхом включення посилання на вміст стандарту, технічної специфікації або кодексу практики. Технічний регламент може бути доповнений технічними настановами та рекомендаціями, які викладаються через певні засоби 3 дотриманням вимог регламенту, а тому вважаються такими, що його задовольняють».

2.3. Абзац 1 ч. 2 ст. 10 після слів «іншими нормативно-правовими актами» доповнити «чи нормативно-технічними документами».

2.4. Частину 2 ст. 11 викласти у новій редакції: «Відповідність продукції вимогам технічних регламентів може бути забезпечена шляхом застосування національних стандартів, технічних специфікацій та/або інших нормативнотехнічних документів, посилання на які містяться у відповідних технічних регламентах. У технічному регламенті зазначається, чи відповідність продукції таким національним стандартам, технічних специфікацій та/або інших нормативно-технічних документів є єдиним способом, чи одним із способів задоволення відповідних вимог технічного регламенту».

2.5. Абзац 1 ч. 1 ст. 16 після слів «чинність національних стандартів» доповнити «чи інших нормативно-технічних документів».

2.6. Абзац 2 ч. 1 ст. 23 після слів «також відомості про стандарти» доповнити «та інші нормативно-технічні документи».

2.7. Статтю 24 доповнити новою частиною: «4. Виробник чи інший суб’єкт господарювання має право застосовувати процедури оцінки відповідності шляхом складання документа про відповідність та/чи шляхом розміщення відповідної інформації на офіційній сторінці в мережі Інтернет. У такому разі суб'єкт господарювання бере на себе відповідальність за відповідність продукції вимогам, зазначеним у документі про відповідність та/чи розміщеним на офіційній сторінці в мережі Інтернет». 
Одночасно варто доручити Кабінету Міністрів України протягом одного місяця у разі прийняття змін до законів України забезпечити приведення своїх нормативно-правових актів та нормативно-правових актів центральних органів виконавчої влади у відповідність до цього Закону.

\section{Висновки до розділу 4}

Сучасна система стандартизації, що функціонує на міжнародному рівні та застосовується в окремих країнах, засновується на основній меті ведення господарської діяльності: досягнення економічних і соціальних результатів при виготовленні та/чи реалізації продукції, виконанні робіт та/чи наданні послуг вартісного характеру, що мають цінову визначеність.

Глобалізаційні процеси, що змусили суб'єктів господарської діяльності вийти за межі національного ринку та формувати міжнародний бізнес, були засновані на таких тенденціях:

1. Постійне нарощування та розвиток продуктивних сил, наукові прориви (науково-технічний розвиток), зокрема в комунікаційній системі.

2. Володіння значними виробничими, комерційними, науково-технічними, фінансовими ресурсами призвело до формування великих корпорацій та банків (промислово-фінансових груп) міжнародного рівня.

3. Лібералізація зовнішньоекономічної політики більшої частини країн світового співтовариства призвела до формування «відкритої економіки».

Метою міжнародною бізнесу так і залишився прибуток, але способи, методи та засоби його отримання коригувалися. Ті країни, що $є$ повноправними та активними членами ISO та інших міжнародних організацій, сьогодні встановлюють стандарти та умови, за якими буде здійснюватися міжнародна торгівля. Стратегію розвитку ISO формують завдання, що полягають не лише у створенні стандартів та їх поширенні, а й несуть соціальну, безпекову та просвітницьку мету, що має полегшити міжнародну торгівлю. Паралельно з ISO 
функціонують регіональні та національні організації стандартизації, що співпрацюють з глобальною організацією, але формують основоположні вимоги для свого регіону з урахуванням національних традицій, усталених правил та інших соціальних засад суспільства у тому чи іншому об'єднанні.

Регіонально організацією у Європі є CEN, члени якої зобов'язані прийняти кожен EN як національний стандарт і зробити його доступним для клієнтів у своїй країні. Таким чином, один EN стає національним стандартом у всіх 34 країнах. CEN, так само як ISO, не виключає залучення неповних членів до своєї роботи зі статусом приєднання чи супутника. Європейська стандартизація є ключовим інструментом консолідації єдиного ринку та полегшення транскордонної торгівлі в межах Свропи та у світі. Це цінний інструмент для підвищення конкурентоспроможності європейських компаній, що створює умови для економічного зростання.

Дослідження організаційно-правових засад стандартизації у окремих країнах Європи засвідчило, що, засновуючись на міжнародних та європейських нормах, переважна більшість країн однаково розуміють стандартизацію як одночи багатостадійну діяльність. У більшості країн наголошують також на наявності статичної та динамічної стадії стандартизації. У цілому всі країни дотримуються позиції, що стандартизація має здійснюватися для реалізації єдиної технічної політики у цій сфері, захисту інтересів споживачів і держави, безпеки товарів і послуг для людини, збереження майна та охорони довкілля.

Аналіз принципів стандартизації у країнах Європи надав можливість дійти висновку, що країни колишнього соцтабору, що ще недалеко відійшли від засад стандартизації, яка здійснювалася в СРСР (так само, як і Україна), обов’язково засновуються на уніфікації, взаємозамінності та сумісності. Водночас, країни, що початково засновувалися на міжнародних нормах у сфері стандартизації, на перше місце серед принципів виносять сучасні аспекти стандартизації: забезпечення торгівлі, усунення технічних бар'єрів та безпеку у різних ії проявах.

Європейські країни надають можливість і допомагають національним суб'єктам господарської діяльності використовувати стандартизацію в якості 
ефективного стратегічного інструменту (формування ринку, безпека інвестицій, підтримка дерегулювання тощо). Стандартизація допомагає полегшити законодавче навантаження на державу, коли законодавці можуть зосередитися на загальних питаннях безпеки, посилаючись на стандарти для технічних деталей. Як інструмент дерегулювання стандарти у Європі $є$ корисними для суб’єктів господарювання та кінцевих споживачів шляхом їх захисту від надмірно жорстких законів з одночасним звільненням держави від відповідальності за складання докладних технічних вимог.

У деяких країнах національним органом стандартизації $\epsilon$ неурядова громадська організація, що досить ефективно здійснює свої функції, отримуючи вотум довіри від суб'єктів публічного та приватного права, надаючи можливість створювати баланс між інструментами імперативного та диспозитивного регулювання відносин у сфері стандартизації.

У питанні розуміння співвідношення стандартів та технічних регламентів європейці сходяться на думці, що технічні регламенти, що входять до законодавчого поля, створюються на основі принципу «посилання на стандарти». Це означає, що технічні вимоги не включаються в технічні регламенти, але надаються посилання на стандарт, який встановлює такі вимоги. Одночасно слід зазначити, що поняття технічного регулювання як виду діяльності у Європі немає.

Так само немає такого поняття і у Канаді, а дослідження організаційноправових основ іiї стандартизації надає можливість дійти висновків: 1) сучасний стан у цій сфері відповідає основним засадам стандартизації у класичних країнах Європи (Німеччині, Франції, країнах Бенілюкс); 2) система стандартизації Канади найбільше інтегрована у світову систему та є іï флагманом; 3) застосування принципу швидкого впровадження досягнень науково-технічного прогресу у стандарти змушує суб'єктів господарювання «підтягуватися» до флагманів галузі; 4) саморегулівні організації, що $є$ базовими організаціями стандартизації, спрощують створення та введення у дію вимог стандартизації, а також оцінку відповідності таким вимогам; 5) до участі у стандартизації в Канаді залучається 
широке коло осіб, у тому числі споживачі; 6) стандартизація допомагає бізнесу та збалансовує інтереси зацікавлених сторін 3 метою лібералізації торгівлі, вирішення спільних суспільних проблем та захисту споживачів.

Ми пропонуємо врегулювати у законодавстві України питання усунення технічних бар'єрів у торгівлі відповідно до умов міжнародних угод про вступ України до СОТ, про асоціацію між Україною й ЄС, про вільну торгівлю з окремими країнами, а також забезпечення прав та інтересів фізичних, юридичних осіб, органів державної влади і місцевого самоврядування та інших зацікавлених осіб. 


\section{Висновки}

У дисертації наведено теоретичне узагальнення i механізм нового вирішення наукового завдання - визначення сутності та особливостей стандартизації, іiі ролі та значення як засобу регулювання господарської діяльності з обгрунтуванням пропозицій і рекомендацій щодо вдосконалення національного законодавства для усунення технічних бар'єрів у торгівлі відповідно до умов міжнародних угод про вступ України до СОТ, про асоціацію між Україною й $Є С$, про вільну торгівлю 3 окремими країнами, а також забезпечення прав та інтересів зацікавлених осіб на основі міжнародних засад стандартизації. У результаті проведеного дослідження сформульовано низку нових наукових положень та висновків, спрямованих на досягнення поставленої мети, основними з яких є такі.

1. Виникнення економічних відносин (створення ринків для обороту товарів і послуг) зумовило необхідність застосування усталених правил, що поступово трансформуються у вимоги до якісних, кількісних та технологічних ознак товарів та послуг. Ці вимоги мали спочатку і нині мають добровільний характер. Лише введення їх у дію актами законодавства спричиняє обов'язковість. Розвиток суб'єктів господарської діяльності та поширення глобалізаційних процесів у суспільстві зумовили поступовий перехід від технічного розуміння стандартизації до безпекового, від зосередження на діяльності учасників господарських відносин до задоволення інтересів кінцевих споживачів, а також відхід від зацикленості вимог стандартизації в межах однієї країни та перехід до вимог, що використовуються світовими економічними організаціями та/чи регіональними об’єднаннями (колективними суб'єктами міжнародного права).

2. У статичному стані стандартизація закріплює вимоги, а у динамічному відбувається їх застосування, оцінка відповідності тощо. Авторське поняття «стандартизація» відображає обидва стани та уточнює, що технічне регулювання $\epsilon$ частиною стандартизації, а стандартизація $\epsilon$ основою для технічного 
регулювання. Стандартизація $є$ частиною правового регулювання, але не охоплюється ним.

Актами регулювання у стандартизації $є$ документи, що містять правила, керівні принципи або характеристики господарської діяльності або їі результатів. Акти регулювання $\epsilon$ зовнішнім виразом вимог стандартизації, що можуть формалізуватися у стандартах, кодексах усталеної практики (настановах, правилах, зведеннях правил), технічних умовах, регламентах, державних класифікаторах, технічних регламентах.

3. Стандартизація є засобом регулювання господарської діяльності. У ст. 12 ГК України закріплено один з тї напрямів (технічне регулювання), що відповідає змісту статті (засоби державного регулювання), але не виключає застосування вимог стандартизації щодо інших засобів з переліку цієї статті. Стандартизація в господарському праві застосовується на засадах: 1) добровільності та саморегулювання, забезпечуючи свободу підприємницької діяльності; 2) обов'язковості та державного регулювання, якщо господарська діяльність створює (може створити) загрозу життю та здоров'ю громадян, довкіллю чи національній безпеці.

4. Суб’єктами стандартизації як засобу регулювання господарської діяльності є юридичні чи інші зацікавлені особи, що здійснюють діяльність із встановлення та/чи застосування вимог стандартизації, у тому числі технічного регулювання, оцінки відповідності та здійснення контролю (нагляду). Класифікацію суб’єктів стандартизації слід здійснювати за ступенем їх участі у цій діяльності.

5. Господарська відповідальність за невиконання (недотримання) вимог стандартизації - це обов’язок особи, винної у такому невиконанні (недотриманні), зазнати передбачені правовою нормою чи договором наслідки особистісного чи майнового характеру 3 метою припинення порушення, охорони суспільного порядку та забезпечення відновлення порушених прав. Правопорушення у цій сфері може бути двох типів: 1) недотримання добровільних вимог нормативно- 
технічних документів зі стандартизації; 2) невиконання обов'язкових вимог нормативно-технічних документів зі стандартизації. Межами, що встановлюються при покладанні юридичної відповідальності за невиконання вимог стандартизації, є: розмір відшкодування, строки настання відповідальності та інші межі, що можуть встановлюватися договірними зобов'язаннями чи нормативно-технічними документами.

6. У переважній більшості країн Європи однаково розуміють стандартизацію як багатостадійну діяльність i наголошують на наявності статичної та динамічної стадії стандартизації. Основними принципами стандартизації у країнах Європи є забезпечення торгівлі, безпеки у різних іiі проявах та усунення технічних бар'єрів. Поняття технічного регулювання як виду діяльності у Європі немає, але широко застосовується саморегулювання у цій cфepi.

7. Нині слід зосередитися на зміні принципових засад функціонування стандартизації: застосуванні стандартів міжнародних організацій; широкому застосуванні принципу добровільності в технічній сфері, але жорсткому застосуванні обов'язковості у безпековій; уніфікації понятійно-змістовного апарату національного законодавства. У зв'язку з цим запропоновано такі зміни до законодавства України:

«1. До Закону Украӥни «Про стандартизаиію»:

1) $n .22 \mathrm{~cm} .1$ викласти у новій редакції: «стандартизація - діяльність, яка здійснюється через взаємний вплив суб'єктів господарської діяльності, держави та інших заџікавлених осіб один на одного для досягнення оптимального поєднання ринкового саморегулювання та державного регулювання з метою захисту економічних і безпекових інтересів держави, суспільства та окремих споживачів шляхом установлення та застосування вимог для загального та неодноразового використання»;

2) ч. 2 cm. 16 викласти у новій редакції та доповнити реченням: «2. Стандарти, кодекси усталеної практики, технічні умови та інші нормативно- 
технічні документи, прийняті підприємствами, установами та організаціями, застосовуються на добровільній основі. Договорами чи в інший спосіб може бути передбачено здійснення добровільної оцінки відповідності продукції цчим вимогам».

2. До Закону України «Про технічні регламенти та оцінку відповідності»:

1) абз. 36 ч. $1 \mathrm{~cm} .1$ доповнити реченням «Технічне регулювання є частиною національної системи стандартизації»;

2) ч. 2 cm. 11 викласти у новій редакиії: «Відповідність продукиії вимогам технічних регламентів може бути забезпечена иляхом застосування національних стандартів, технічних специфікацій та/або інших нормативнотехнічних документів, посилання на які містяться у відповідних технічних регламентах. У технічному регламенті зазначається, чи $\epsilon$ відповідність продукиї таким національним стандартам, технічним специифікаціям та/або іншим нормативно-технічним документам єдиним способом чи одним із способів задоволення відповідних вимог технічного регламенту»;

3) $\mathrm{cm} .24$ доповнити новою частиною: «4. Виробник чи інший суб'єкт господарювання має право застосовувати процедури оцінки відповідності шляхом складання документа про відповідність та/чи иляхом розміщення відповідної інформації на офіиійній сторіниі в мережі Інтернет. У такому разі суб’єкт господарювання бере на себе відповідальність за відповідність продукиії вимогам, зазначеним у документі про відповідність та/чи розміщеним на офіиійній сторіниі в мережі Інтернет». 


\section{СПИСОК ВИКОРИСТАНИХ ДЖЕРЕЛ}

1. Абова Т. Е. Правовые аспекты совершенствования хозяйственного механизма. М.: Знание, 1987. 64 с.

2. Алексеев С. С. Механизм правового регулирования в социалистическом государстве. М., 1966.187 с.

3. Алексеев С. С., Яковлев В. Ф. Правовое регулирование хозяйственных отношений//Советское государство и право. М., 1979. № 3. С. 61-69.

4. Алексеев C. С. Правовые средства: постановка проблемы, понятие, классификация//Сов. государство и право. 1987. № 6. С. 14-18.

5. Алексеев С. С. Теория права. М., 1995. 320 с.

6. Анохин В. С. Правовая работа в народном хозяйстве в новых экономических условиях. Воронеж, 1991. 328 с.

7. Атаманова Ю. С. Господарсько-правове забезпечення інноваційної політики держави: монографія. Харків, 2008. 424 с.

8. Ашурков О. А., Дутов М. М. Проблемы гармонизации хозяйственного законодательства Украины с законодательством Европейского Союза. Донецк, $2005.34 \mathrm{c}$.

9. Ашурков О. А. Проблемы реализации регуляторной политики в сфере хозяйствования. Хозяйственное законодательство Украины: практика применения и перспективы развития в контексте европейского выбора: сб. науч. тр./редкол. Мамутов В. К. (отв. ред.) и др.Донецк, 2005. С. 65-70.

10. База даних законодавства СС [Електронний pecypc]. http://eur-lex.europa.eu/ homepage.html?locale=en (дата звернення 23.09.2017).

11. База даних Європейських стандартів [Електронний ресурс]. URL: https://standards.cen.eu (дата звернення 23.09.2017).

12. Бакалінська О. О. Правові проблеми розвитку саморегулювання в сфері добро- 
совісної конкуренції// Право і суспільство. 2014. Вип. 2. С. 63-69.

13. Бардин И. П. Упорядочить дело стандартизации и нормализации//Стандартизация. 1965. № 9. С. 21-23.

14. Беляневич О. А. Господарський договір та способи його укладання: навч. посібник. К., 2002. 278 с.

15. Беляневич О.А. Теоретичні проблеми господарського договірного права: дис. ... докт. юрид. наук: спец. 12.00.04. К., 2006. 506 с.

16. Бесараб Т. В. Маркування - це обличчя продукції та запорука іï якості [Електронний pecypc].

URL:

http://csm.kiev.ua/index.php?option=com_content\&view=article \&id=3249\%253A2015 -09-07-06-55-28\&catid=1\%253Alatest-news\&Itemid=120\&lang=ua (дата звернення 01.12.2016).

17. Бобровник С. В., Оніщенко Н. М. Соціальна та юридична ефективність законодавства//Законодавство: проблеми ефективності. К., 1995. С. 13-26.

18. Бойцов В. В. Эффективность производства, стандарты и качество//Стандарты и качество.1977.№ 11. С. 3-8.

19. Брославский Л. И. Ответственность за качество/отв. ред. Б. И. Пугинский. М., 1987. $128 \mathrm{c}$.

20. Брославский Л. И. Юридическая ответственность предприятий и объединений за качество поставляемой продукции по гражданскому законодательству//Стандарты и качество.1984.№ 3. С. 50-53.

21. Бурлаченко Н. Ф. Формирование права хозяйственных систем как подотрасли хозяйственного права Украины/Хозяйственное законодательство Украины: практика применения и перспективы развития в контексте европейского выбора: сб. науч. тр./редкол. Мамутов В. К. (отв. ред.) и др. Донецк, 2005. С. 403-407.

22. Венгеров А. Б., Мицкевич А. В. Закон и законность в хозяйственной деятельности. М., 1973. 64 с.

23. Венедиктов А. В. Государственная социалистическая собственность. М.-Л., $1948.839 \mathrm{c}$. 
24. Венедиктов Ю. А., Черепахин А. М. Финансовые санкции в системе управления. М., 1985. 64 с.

25. Витченко А. М. Механизм правового регулирования социалистических общественных отношений, его понятие и структура//Вопросы государства и права. Саратов, 1968. С. 65-92.

26. Вихров А. П. Правовые средства обеспечения качества продукции//Стандарты и качество. 1984. № 2. С. 50-51.

27. Вінник О. М. Господарське право: курс лекцій. К., 2004. 624 с.

28. Вінник О. М. Господарське право: навч. посіб. 2-ге вид., змін, та доп. К., 2008. $766 \mathrm{c}$.

29. Віхров О. П. Організаційно-господарські правовідносини: монографія. К., 2008. $512 \mathrm{c}$.

30. Волжин С. Н. Тема семинара повышение эффективности мер, принимаем к нарушителям требований стандартов//Стандарты и качество. 1977. № 8. С. 83-84.

31. Волков В. Ю. Суб'єкти адміністративно-правового регулювання в галузі стандартизації та сертифікації//Форум права. 2013. № 1. С. 145-149 [Електронний pecypc]. URL: http://nbuv.gov.ua/UJRN/FP_2013_1_26.pdf (дата звернення 16.12.2016).

32. Волкова Г. І. Еколого-правові проблеми виробництва і споживання екологічно чистої продукції//Хозяйственное законодательство Украины: практика применения и перспективы развития в контексте европейского выбора: сб. науч. тр./редкол. Мамутов В. К. (отв. ред.) и др.Донецк, 2005. С. 89-92.

33. Впровадження систем управління якістю при наданні муніципальних послуг у відповідності до вимог ISO 9001:2008: існуючі практики та напрями удосконалення. К, 2013. 56 с. [Електронний ресурс]. URL: http://www.undp.org.ua/files/ua_47138PROON-2012-Analit(last).pdf (дата звернення 12.12.2016).

34. Гамбург I. А. Технічне регулювання господарської діяльності: поняття та співвідношення з правом//Хозяйственное законодательство Украины: практика 
применения и перспективы развития в контексте европейского выбора: сб. науч. тр./редкол. Мамутов В. К. (отв. ред.) и др. Донецк, 2005. С. 496-500. - С. 496-497; 35. Ганзенко О. О. Формування правової культури особи в умовах розбудови правової держави Україна : автореф. дис. ... канд. юрид. наук: 12.00.01. К., 2003. $16 \mathrm{c}$.

36. Генкин Д. М. Актуальные вопросы правового регулирования советской государственной торговли//Советское государство и право. 1961. № 8. С. 39-49. 37. Головань I. В. Правова робота і захист прав підприємців: монографія. Донецьк, 2003. 168 с.

38. Горницкий А. А. Государственная дисциплина. К., 1989. 132 с.

39. Горшенев В. М. Способы и организационные формы правового регулирования в социалистическом обществе. М., 1972. 258 с.

40. Господарське право: Навч. посібник у схемах і таблицях/за заг. ред. Шелухіна М.Л. К., 2006. 616 с.

41. Господарське право України: підручник/В. М. Гайворонський, В. П. Жушман, Н. В. Погорецька та ін./за ред. В. М. Гайворонського та В. П. Жушмана. Х., 2005. $384 \mathrm{c}$.

42. ГОСТ 1.0-68 «Государственная система стандартизации. Основные положения». М., 1969. С. 5.

43. Грудницька С. М.Господарська правосуб'єктність державних підприємств: автореф. дис... докт. юрид. наук: спец. 12.00.04. Донецьк, 2012. 34 с.

44. Грудницька С.M. Господарська правосуб’єктність: проблема визначення поняття та сутності//Підприємництво, господарство і право. 2008. № 9. С. 65-67. 45. Грудницкая С.Н. Структура хозяйственной правосубъектности предприятий в современной экономике//Правова держава. 2011. № 13. С. 51-57.

46. Гурак Л. В. Особливості регулювання та управління господарською діяльністю державних вищих навчальних закладів // Вісник Національної юридичної академії України імені Ярослава Мудрого. 2011. № 6. С. 154-162. (Серія "Економічна теорія та право"). 
47. Декрет Совета Народных Комисаров «О введении международной метрической системы мер та весов» от 14 сентября 1918 г. № 725//Собрание узаконений и распоряжений правительства за 1917-1918 гг. Управление делами Совнаркома СССР. М., 1942. С. 902-903.

48. Демченко С. Ф. Теоретико-методологічні засади ефективності господарського судочинства: автореф. дис. ... д-ра юрид. наук : 12.00.04. К., 2010. 36 с.

49. Деревянко Б. В. Ліцензування як засіб регулюючого впливу держави на діяльність навчальних закладів / Форум права. 2011. № 4. С. 167-178 [Електронний pecypc]. URL: http://www.nbuv.gov.ua/e-journals/FP/20114/11dbvdnz.pdf.

50. Деревянко Б. В. Послуги у сфері освіти: правове регулювання: монографія. Донецьк, 2013. 387 с.

51. Деревянко Б.В. Про удосконалення здійснення державного контролю та нагляду за діяльністю суб'єктів господарювання // Юридичний науковий електронний журнал. 2015. № 4. C. 99-102. URL: http://www.lsej.org.ua/4_2015/26.pdf.

52. Деревянко Б. В. Правове регулювання господарської діяльності навчальних закладів: дис. д-ра юрид. наук, спец.: 12.00.04. Донецьк, 2014. 504 с.

53. Джабраілов Р. А. Категорія «публічний господарський інтерес» у сфері господарювання//Правове регулювання господарських відносин в окремих галузях економіки: напрями вдосконалення: зб. наук. пр. /редкол. Мамутов В. К. (відп. ред.) та ін. Донецьк, 2008. С. 70-83. - С. 80

54. Джунь В. Методологічні питання дослідження господарського права// Вісник Академії правових наук України. 2010. № 1. С. 154-168.

55. Добровольська $\quad$ В. $\quad$ В. Правове забезпечення державного регулювання економіки: монографія. Одеса, 2010. 258 с.

56. Дробязко С. Г. Предмет, сфера, объект правового регулирования в условиях формирования социального правового государства и правового гражданского общества//Выбр. навук. пр. БеларуС. дзярж. ун-та: у 7 т. Минск, 2001. Т. 3. С. 9-24; 
57. ДСТУ 1.4-93 Державна система стандартизації України. Стандарти підприємства. Основні положення. К., 1994. 6 с.

58. ДСТУ 3718:2007 Концентрати харчові. Солодкі страви. Желе, муси, пудинги, концентрати молочні. Загальні технічні умови. К., 1994. 13 с.

59. ДСТУ 4427:2005 Ковбаси сирокопчені та сиров'ялені. Загальні технічні умови. K., 2006. 27 c.

60. ДСТУ ISO 22000:2007 (ISO 22000:2005, IDT) Національний стандарт України. Системи управління безпекою харчових продуктів. Вимоги до будь-яких організацій харчового ланцюга. К., 2007. 39 с.

61. ДСТУ ISO 9001:2015 (ISO 9001:2015, IDT) Національний стандарт України. Системи управління якістю. К., 2015. 31 с.

62. ДСТУ ISO 14001:2015 (ISO 14001:2015, IDT) Національний стандарт України. Системи екологічного управління. Вимоги та настанови щодо застосовування. К., $2015.37 \mathrm{c}$.

63. ДСТУ OHSAS 18001:2010 (OHSAS 18001:2007, IDT) Системи управління гігієною та безпекою праці. Вимоги. К., 2011. 27 с.

64. Дудла І. О. Захист прав споживачів: навч. посібник. К., 2007. 448 с.

65. Егоров Н. Д. Гражданско-правовое регулирование экономических отношений: учеб. пособие. Л., 1986. 213 с.

66. Емельянова М. Б. Согласованность правового регулирования поставки и стандартизация как средство укрепления договорной дисциплины и улучшения качества продукции//Хозяйственное право и эффективность производства. М., 1981. С. $81-85$.

67. Емельянова M. О правовых основах государственной системы стандартизации//Стандартизация. 1965. № 10. С. 50-51.

68. Енциклопедія Трипільської цивілізації/Бурдо Н. Б. (відп. секр.), Відейко М. Ю. (гол. ред.) та інші. К., 2004. Т. 1. Кн. 1.703 с. 
69. Свропейський фонд управління якістю. Fundamental Concepts of EFQM. European Foundation of Quality Management [Електронний ресурc]. URL: http://www.efqm.org/efqm-model/fundamental-concepts (дата звернення: 01.10.2016). 70. Єршова С. І. Визначення поняття господарської діяльності, іiі ознаки//Держава та регіони. Сер. Право. 2012. Вип. 2. С. 118-123.

71. Жабин А. П. Роль экономических норм и нормативов в совершенствовании хозяйственного механизма//Хозяйственное право и эффективность производства. M., 1981. C. 22-28.

72. Загальна теорія держави і права/М. В. Цвік, В. Д. Ткаченко, Л. Л. Богачова та ін./за ред. М. В. Цвіка, В. Д. Ткаченка, О. В. Петришина. Харків, 2002. 432 с.

73. Задихайло Д. В. Правовий господарський порядок в Україні: десятирічний досвід конституційно-правового забезпечення//Вісник Академії правових наук України. 2006. № 3(46). С. 143-153.

74. Заєць А. П. Правова держава в контексті новітнього українського досвіду. К., 1999. $248 \mathrm{c}$.

75. Закон України «Про захист прав споживачів»//Інформаційно-пошукова система База даних «Законодавство». Версія 2.8.8. («Назва з екрану»).

76. Заменгоф 3. М. Сочетание государственного планового руководства и хозяйственной самостоятельности в договорных отношениях//Советское государство и право. 1963. № 2. С. 33-44

77. Замойский И. Е. Эффективность хозяйственно-правовой работы. К., 1982. 168 c.

78. Збірник директив ЄС 3 питань державних закупівель. К., 2015. 637 с. [Електронний pecypc]. http://eupublicprocurement.org.ua/wpcontent/uploads/2015/02/EU-PP-Directives-Compendium_UKR.pdf (дата звернення 23.09.2017).

79. Зверева Е. В. Договор как средство обеспечения качества товаров//Хозяйственное законодательство Украины: практика применения и 
перспективы развития в контексте европейского выбора: сб. науч. тр./редкол. Мамутов В. К. (отв. ред.) и др. Донецк, 2005. С. 489-493.

80. Зверева Е. В. Обеспечение защиты прав потребителей в сфере хозяйственных отношений//Правове регулювання господарських відносин в окремих галузях економіки: напрями вдосконалення: зб. наук. пр./редкол. Мамутов В. К. (відп. ред.) та ін. Донецьк, 2008. С. 52-59.

81. Зверева Е. В. Хозяйственно-правовая защита потребительского рынка: монография. Луганск, 2010. 396 с.

82. Землеглядов К. Г. Роль и место стандартизации в научно-техническом прогрессе//Стандарты и качество. 1968. № 5. С. 3-6.

83. Знаменский Г. Л. Задачи научного обеспечения модернизации хозяйственного законодательства//Проблеми господарського права і методика його викладання: зб. наук. праць/редкол. Мамутов В. К. (відп. ред.) та ін. Донецьк, 2006. С. 408-416. 84. Знаменський Г. Економічна політика і законодавство//Право України. 2008. № 7. C. $40-43$.

85. Знаменський $Г$. Л. Приватноправовий аспект у господарському законодавстві//Методологія приватного права: зб. наук. праць (за матеріалами наук.-теорет. конф.). К., 2003. С. 156-157.

86. Знаменський Г. Л. Системне узгодження державної економічної політики та законодавства//Напрями оновлення господарського законодавства України: зб. наук. праць/ред. кол. Мамутов В. К. (відп. ред.) та ін. Донецьк, 2008. С. 5-19.

87. Знаменский Г. Л. Функции теории хозяйственного законодательства//XXVI съезд КПСС и правовые вопросы совершенствования хозяйственного механизма/отв. ред. В. В. Лаптев. М., 1982. С. 32-35.

88. Исаев И. А. Становление хозяйственно-правовой мысли в СССР (20-е годы). M., 1986. $176 \mathrm{c}$.

89. Іванов В. М. Історія держави і права України: навч. посіб. К., 2002. Ч. 1. 264 с. 
90. Інформація про відділ стандартизації і метрології ХНАДУ [Електронний pecypc]. URL: http://www.khadi.kharkov.ua/home/administrativni-pidrozdili/viddilstandartizaciji-i-metrologiji.html (дата звернення 12.12.2016).

91. Ісаков М. Г. Роль держави у регулюванні підприємницької діяльності в умовах ринкової економіки//Митна справа. Ч. 2. Кн. 2. 2012. № 1 (79). С. 354-360.

92. Історична довідка про Державне підприємство «Чернівецький регіональний науково-виробничий центр стандартизації, метрології та сертифікації» [Електронний pecypc]. URL: http://www.dpbsm.cv.ua/history.htm (дата звернення 17.08.2016).

93. Історія розвитку «Сварог Вест Груп» [Електронний ресурс]. URL: http://svarogagro.com/uk/at-a-glance/history\%20of\%20development (дата звернення 15.08.2016). 94. Калита П.Я. Грани качества. Лирика. Публицистика. К.,2014. 366 с.

95. Керівництво для членів Міжнародної організації стандартизації - ISO membership manual [Електронний pecypc]. URL: https://www.iso.org/files/live/sites/isoorg/files/archive/pdf/en/iso_membership_manual. pdf (дата звернення 23.09.2017).

96. Кожемякин С. А. Формирование права хозяйственных систем как подотрасли хозяйственного права Украины/Хозяйственное законодательство Украины: практика применения и перспективы развития в контексте европейского выбора: сб. науч. тр./редкол. Мамутов В. К. (отв. ред.) и др. Донецк, 2005. С. 189-193. 97. Козырь М. И. Право и совершенствование хозяйственного механизма в агропромышленном комплексе//XXVI съезд КПСС и правовые вопросы совершенствования хозяйственного механизма/отв. ред. В. В. Лаптев. М., 1982. С. 165-179.

98. Колбасов О. С., Бринчук М. М. Нормирование как правовая мера охраны окружающей среды//Советское государство и право. 1987. № 3. С. 72-80.

99. Колбасов О. С. Правовая охрана природы в СССР//Советское государство и право. 1967. № 10. С. 41-48. 
100. Комаров Д. М., Еремеева А. Б. О применении системы оптимизации опережающей стандартизации//Стандарты и качество. 1983. № 5. С. 10-13.

101. Компания LifeCar гарантирует качество и оригинальность продукта. [Електронний pecypc]. URL: http://lifecar.com.ua/politikabezopasnosti (дата звернення 12.12.2016).

102. Коростей В. И. Нормативные акты субъектов хозяйствования//Хозяйственное законодательство Украины: практика применения и перспективы развития в контексте европейского выбора: сб. науч. тр./редкол. Мамутов В. К. (отв. ред.) и др. Донецк, 2005. С. 53-56.

103. Коростей В. И. Трансформация системы правового регулирования хозяйственной деятельности: проблемы, реализация, перспективы: монография. Донецк, $2008.321 \mathrm{c.}$

104. Коростей В. Система правового регулювання господарювання: реалізація $\mathrm{i}$ перспективи//Право України. 2007. № 4. С. 78-84.

105. Кохтев А. А. Стандартизация в народном хозяйстве в СССР в послевоенный период //Стандарты и качество. 1967. № 11. С. 14-15.

106. Кравцова Т. М. Державна регуляторна політика у сфері господарської діяльності: організаційно-правові засади реалізації: монографія/за заг. ред. О. М. Бандурки. Харків, 2004. 266 с.

107. Кудрявцева Л. Примхлива соя//Агро бізнес сьогодні. № 7(326). Квітень 2016 [Електронний pecypc]. URL: http://www.agro-business.com.ua/ekonomichnyigektar/5154-prymkhlyva-soia.html (дата звернення 20.06.2016).

108. Кузнецов В. С. Государственный надзор за внедрением и соблюдением стандартов в хозяйственной деятельности//XXVI съезд КПСС и правовые вопросы совершенствования хозяйственного механизма/отв. ред. В. В. Лаптев. М., 1982. C. 94-98.

109. Лаптев B. В. Хозяйственный механизм и хозяйственное право// Хозяйственное право и эффективность производства. М., 1981. С. 4-11. 
110. Лаптев B. B. XXVI съезд КПСС и совершенствование правового регулирования руководства народным хозяйством//XXVI съезд КПСС и правовые вопросы совершенствования хозяйственного механизма/отв. ред. В. В. Лаптев. М., 1982. C. 5-16.

111. Лаптин М. Н., Седлов П. А. Стимулирование технического прогресса //Советское государство и право.1970.№ 10. С. 90-94.

112. Лепіш Н. Я. Історія становлення метрології, стандартизації та сертифікації на території України (V ст. до н.е. ХІІІ ст.)//Митна справа. 2011. № 6 (78). Ч. 2. Кн. 1. C. $103-109$.

113. Лепіш Н. Я. Механізм адміністративно-правового регулювання в галузі стандартизації, якості продукції, метрології та сертифікації//Митна справа. 2011. №5(77). Ч. 2. С. 298-303.

114. Лещук А. Г. Определение термина «стандартизация»//Стандарты и качество. 1968. № 5. C. $8-10$.

115. Либерман Ф. Х. Арбитражная практика по делам о качестве и комплектности продукции//Советское государство и право. 1963. № 12. С. 132-138.

116. Луць В. В. Договор в механизме социалистического хозяйствования//XXVI съезд КПСС и правовые вопросы совершенствования хозяйственного механизма/отв. ред. В. В. Лаптев. М., 1982. С. 120-126.

117. Маевский С. А. Об организационно-правовых формах государственного руководства техническим прогрессом промышленности//Советское государство и право.1963.№ 2. С. 23-32.

118. Малько А. В., Пестова Т. П. Локальные правовые акты как средство реализации правовой политики//Правовая политика и правовая жизнь. 2009. № 3. C. 197-201.

119. Мальков В. В. О путях расширения полномочий общественного контроля в условиях общенародного государства//Советское государство и право. 1963. № 12. C. $55-65$. 
120. Маматов В. , Маматова Т. Система оцінювання якості діяльності органів державного контролю//Стандартизація. Сертифікація. Якість. 2008. № 5. С. 40-44. 121. Мамутов В. К. Предприятие и вышестоящий хозяйственный орган. М., 1969. $237 \mathrm{c}$.

122. Мамутов В. К. Совершенствование правового регулирования хозяйственной деятельности (методология, направления)/отв. ред. В. В. Лаптев. К., 1982. 238 с. 123. Матузов Н. И., Малько А. В. Теория государства и права: учебник. 2004. 512 с. 124. Метрологія, стандартизація та управління якістю: навч. посіб.: у 2 ч./Л. П. Клименко та ін./під ред. В. Д. Євдокимова. Одеса; Миколаїв, 2011. Ч. 1. 243 с. 125. Мілаш В. С. Господарське право: курс лекцій: у 2 ч. Х., 2008. Ч. 1. 496 с. 126. Мироненко Н. М. Наукові засади державного регулювання та державного управління у сфері підприємництва: зміст та співвідношення // Система органів державного управління та регулювання в сфері підприємницької діяльності. К., 2010. C. 27-52.

127. Мюллер Г. Формообразование и стандартизация//Стандарты и качество. 1967. № 10. C. 15-18.

128. Наказ Мінбуд України, Держбуд України «Про утворення робочих груп із перегляду регуляторних актів» від 10.06.2005 року № 93//ннформаційно-пошукова система База даних «Законодавство». Версія 2.8.8. («Назва з екрану»).

129. Наказ Мінприроди України «Методика визначення розмірів плати i стягнення платежів за забруднення навколишнього природного середовища України» від 14.05.1993 року № 46//ннформаційно-пошукова система База даних «Законодавство». Версія 2.8.8. («Назва з екрану»).

130. Наказ Мінприроди України «Про затвердження Методики визначення розмірів відшкодування збитків, заподіяних державі внаслідок самовільного користування надрами» від 29.08.2011 року № 303//Інформаційно-пошукова система База даних «Законодавство». Версія 2.8.8. («Назва з екрану»).

131. Наказ Мінприроди України «Про затвердження Методики розрахунку розмірів відшкодування збитків, заподіяних державі внаслідок порушення 
законодавства про охорону та раціональне використання водних ресурсів» від 20.07.2009 року № 389//Інформаційно-пошукова система База даних «Законодавство». Версія 2.8.8. («Назва з екрану»).

132. Наказ Мінприроди України «Про затвердження Методики розрахунку розмірів відшкодування збитків, які заподіяні державі в результаті наднормативних викидів забруднюючих речовин в атмосферне повітря» від 10.12.2008 року № 639//Інформаційно-пошукова система База даних «Законодавство». Версія 2.8.8. («Назва з екрану»).

133. Наказ Мін'юсту України «Про вдосконалення порядку державної реєстрації нормативно-правових актів у Міністерстві юстиції України та скасування рішення про державну реєстрацію нормативно-правових актів» від 12.04 .2005 року № 34/5//Інформаційно-пошукова система База даних «Законодавство». Версія 2.8.8. («Назва з екрану»).

134. Наказ Мінрегіонбуд «Про утворення робочої групи з перегляду нормативних документів комплексу "Система проектної документації для будівництва" та про затвердження переліку НД, які підлягають перегляду» від 29.08.2008 року № 390//Інформаційно-пошукова система База даних «Законодавство». Версія 2.8.8. («Назва з екрану»).

135. Наказ MO3 України «Про затвердження персонального складу мультидисциплінарних робочих груп 3 розробки медичних стандартів (уніфікованих клінічних протоколів) медичної допомоги на засадах доказової медицини у 2016 році» від 12.05.2016 року № 437//Інформаційно-пошукова система База даних «Законодавство». Версія 2.8.8. («Назва з екрану»).

136. Наказ ДП «УкрНДНЦ» «Про створення робочої групи 3 розроблення проектів основоположних національних стандартів національної системи стандартизації» від 17.04.2015 року № 31//Інформаційно-пошукова система База даних «Законодавство». Версія 2.8.8. («Назва з екрану»). 
137. Наказ Міносвіти «Про створення робочих груп 3 розроблення галузевих стандартів вищої освіти» від 11.10.2007 року № 897//Інформаційно-пошукова система База даних «Законодавство». Версія 2.8.8. («Назва з екрану»).

138. Науково-практичний коментар Господарського кодексу України/O. А. Беляневич, О. М. Вінник, В. С. Щербина та ін./за заг. ред. Г. Л. Знаменського, В. С. Щербини. 2-ге вид., перероб. і доп. К., 2008. 714 с.

139. Неофіційний переклад Регламенту (ЄС) № 374/2014 Європейського Парламенту і Ради від 16 квітня 2014 року щодо скорочення або скасування митних тарифів на товари, що походять 3 України [Електронний ресурс]. http://www.chernihiv-oblast.gov.ua/media/upload/1_-_regulation_eu_-

_374_2014_annex_i_.pdf (дата звернення 23.09.2017).

140. Нерсесянц B. С. Право в системе социальной регуляции//История и современность. М., 1986. 64 с.

141. Никитин П. И. Стандартизация организации и техники управления//Стандарты и качество. 1967. № 11. С. 67-68.

142. Никитченко $\quad$ H. $\quad$ В. Суб’єкти державного контролю у господарській сфері//Право і суспільство. 2014. № 5.2. С. 229-232. URL: http://nbuv.gov.ua/UJRN/Pis_2014_5.2_52.

143. Общая схема оценки (CAF) (версия 2006). URL: http://www.eipa.eu/files/File/CAF/Brochure2006/RUS-CAF-2009.pdf (дата звернення 12.12.2016).

144. Общая теория государства и права: учебник: академ. курс в 2-х томах/М. И. Байтин, А. Г. Бережнов, Н. В. Витрук и др./под ред. М. Н. Марченко. Т. 2. Теория права. М., 1998. 656 с.

145. Оверчук Л. П. Українська практика впровадження технічних регламентів щодо виробів медичного призначення в умовах реформування галузі охорони здоров'я. URL: http://www.investplan.com.ua/pdf/11_2012/30.pdf (дата звернення 22.07.2016). 
146. Овчаренко P. В. Правовое обеспечение соблюдения обязательных требований к качеству продукции//Проблеми господарського права і методика його викладання: зб. наук. праць/редкол. Мамутов В. К. (відп. ред.) та ін. Донецьк, 2006. C. 295-307.

147. Огрызков В. М. Регулирование качества продукции и стандартизация// Советское государство и право. 1970. № 8. С. 92-96.

148. Орєхов С. М. Адміністративно-правове регулювання в галузі стандартизації, якості продукції, метрології і сертифікації: дис. ... канд. юрид. наук: 12.00.07. К., $2011.23 \mathrm{c}$.

149. Орлов Б. М. Изучение стандартизации как целостной системы/Стандарты и качество. 1967. № 8. С. 14-15.

150. Орлов Н. А., Пашова М. С. Стандарты и качество сельскохозяйственной продукции//Советское государство и право. 1987. № 3. С. 48-52.

151. Орлов Н. А. Эколого-правовые проблемы обеспечения устойчивого управления социально-экономическими процессами//Хозяйственное законодательство Украины: практика применения и перспективы развития в контексте европейского выбора: сб. науч. тр./редкол. Мамутов В. К. (отв. ред.) и др. Донецк, 2005. С. 71-74.

152. Осика І. В. Правова культура у формуванні правової, соціальної держави: автореф. дис. ... канд. юрид. наук: 12.00.01. К., 2004. 20 с.

153. Основи методології та організації наукових досліджень: Навч. посіб. для студентів, курсантів, аспірантів і ад’юнктів/за ред. А. Є. Конверського. К., 2010. $352 \mathrm{c}$.

154. Офіційні матеріали про перші 50 років діяльності ISO (1947-1997) [Електронний ресурc]. URL: http://www.iso.org/iso/ru/2012_friendship_among_ equals.pdf (дата звернення 12.11.2016).

155. Памятники русского права/под ред. проф. Л. В. Черепнина. Вып. 3. М., 1955. $528 \mathrm{c}$. 
156. Парций Я. Е. Об административной ответственности за нарушение правил в области стандартизации, качества продукции и метрологии//Стандарты и качество. 1984. № 9. С. 44-48.

157. Пахомов И. Н. Некоторые теоретические вопросы правового регулирования хозяйственных отношений//Хозяйственное право и эффективность производства. M., 1981. C. 19-22.

158. Перелік посилань на акти $\mathrm{CC}$, що були офіційно опубліковані [Електронний pecypc]. old.minjust.gov.ua/file/31572 (дата звернення 23.06.2016).

159. Переліки національних стандартів під технічні регламенти [Електронний pecypc]. URL: http://www.me.gov.ua/Documents/List?lang=uk-UA\&id=fbe1ad1b6d48-407e-a2bd-aae55f31afec\&tag=PerelikiNatsionalnikhStandartivPidTekhnichni Reglamenti (дата звернення 06.06.2016).

160. Перспективы стандартизации и реконструкция народного хозяйства СССР (Доклады на пленуме Совета по стандартизации при СТО 12 апреля 1929 г.). М., 1929. $30 \mathrm{c}$.

161. План заходів із впровадження Технічного регламенту щодо медичних виробів для лабораторної діагностики invitro на 2008 - 2013 роки [Електронний pecypc]. URL: http://diklz.gov.ua/sites/default/files/files/in\%20vitro.pdf (дата звернення 20.06.2016).

162. Плахотный А. Ф. Свобода и ответственность: социологический аспект проблемы. Харьков, 1972. 159 с.

163. Плахута В. Г. Экологизация хозяйственного законодательства в сфере сельськохозяйственого производства//XXVI съезд КПСС и правовые вопросы совершенствования хозяйственного механизма/отв. ред. В. В. Лаптев. М., 1982. С. 240-247.

164. Побирченко И. Г. Основы хозяйственного права. К., 1983. 20 С. С. 9

165. Подопригора А. А. Правовое регулирование научно-технического прогресса: учеб. пособие для юрид. вузов. К., 1981. 152 с. 
166. Подцерковний О. П. Врахування співвідношення економічних та юридичних відносин при викладенні господарсько-правових дисциплін//Проблеми господарського права і методика його викладання. Донецьк, 2006. С. 378-386. 167. Полежай П. Т., Шелестов В. С. О соотношении юридических и технических норм в социалистическом обществе//Советское государство и право. 1960. № 10. C. $13-21$.

168. Попович Т. Г. Визначення критеріїв ефективності стандартів у сфері охорони довкілля // Приватне право і підприємництво. Вип. 4. 2005. С. 183-188.

169. Попович Т. Г. Впровадження стандартизації в господарській діяльності як прояв захисту суб'єктивних цивільних прав // Проблеми здійснення та захисту суб’єктивних цивільних прав: Збірник наукових праць. К., 2012. С. 148-150. 170. Попович Т. Г. Господарська діяльність в умовах дії Угоди про асоціацію України з ЄС // Приватне право і підприємництво. 2017. Вип. 17. С. 152-156. 171. Попович Т. Г. Додаткові елементи механізму правового регулювання стандартизації в господарському праві // Актуальні проблеми реформування земельних, аграрних та господарських відносин: збірник тез Міжнародної науково-практичної конференції (м. Хмельницький , 17-18 травня 2013 року). Хмельницький, 2013. С. 424-427

172. Попович Т. Г. Зміна правових засад у сфері технічного регулювання в Україні відповідно до вимог $\mathrm{CC//Приватне} \mathrm{право} \mathrm{і} \mathrm{підприємництво.} \mathrm{Збірник}$ наукових праць. Вип. 15, 2016 р./Редкол.: Крупчан О. Д. (гол. ред.) та ін. К., 2016. - C. 141-144.

173. Попович Т. Г. Екологічний менеджмент акціонерних товариств: економікоправовий аспект // Корпоративне право в Україні: становлення та розвиток. Збірник наукових праць. К., 2004. С.228-233.

174. Попович Т. Г. Екологічно безпечне житло: реалії та правове регулювання. К., 2006. $32 \mathrm{c}$. 
175. Попович T. Г. Європейський Союз: перспективи для українських підприємств// Нормативно-правове забезпечення євроатлантичної інтеграції України. Вип. 1. К., 2004. С. 159-161.

176. Попович Т. Г. Міжнародно-правові основи стандартизації як засобу регулювання господарської діяльності // Міжгалузеві зв'язки цивільного, господарського та трудового права: матеріали Веукраїнської науково-практичної конференції (в авторській редакції), (м. Кривий Ріг, 28 вересня 2017 року): [у 2-х част.]. Ч. 1. Кривий Ріг, 2017. С. 183-187.

177. Попович Т. Г. Особливості застосування стандартизації в умовах набуття чинності Угодою про асоціацію між Україною та ЄС // Проблеми модернізації приватного права в умовах євроінтеграції: збірник наукових праць. Хмельницький, 2015. С. 188-194.

178. Попович Т. Г. Правові аспекти приведення у відповідність до вимог ЄС системи технічного регулювання у сфері господарської діяльності в Україні // Забезпечення міжнародної приватноправової інтеграційної стратегії. К., 2017. С. $156-172$.

179. Попович Т. Г. Регулювання господарської діяльності 3 допомогою стандартизації на основі принципу добровільності // Діалектика публічних і приватних інтересів у державному регулюванні економіки: Зб. матеріалів «Круглого столу». К., 2013. С. 176-181.

180. Попович Т. Г. Співвідношення стандартизації та технічного регулювання у господарському праві // Збірник праць XII аспірантських та магістерських читань «Актуальні проблеми розвитку України у контексті сучасних світових тенденцій» (23 листопада 2017 року, м. Київ). К., 2018. С. 122-128.

181. Попович Т. Г. Стандартизація чи технічне регулювання: вдосконалення понятійного апарату господарського права на основі міжнародного досвіду // Юридична Україна. 2018. № 1-2. С. 59-65.

182. Попондопуло В. Ф. Правовой режим предпринимательства. С.-Пб., 1994. 208 с. 
183. Посібник до вивчення дисципліни «Методологія та організація наукових досліджень»/Ф.О. Чмиленко,. Л. П. Жук. Дніпро, 2014. 48 с.

184. Посилання для закачування стандарту CAN/CSA-Z1003-13/BNQ 9700803/2013 [Електронний pecypc]. URL: http://shop.csa.ca/en/canada/occupationalhealth-and-safety-management/cancsa-z1003-13bnq-9700-8032013/invt/z10032013 (дата звернення 23.09.2017).

185. Постанова Кабінету Міністрів України «Про затвердження Спеціальних вимог до призначених органів з оцінки відповідності» від 13.01.02016 року № 56//Інформаційно-пошукова система База даних «Законодавство». Версія 2.8.8. («Назва з екрану»).

186. Постанова Кабінету Міністрів України «Про затвердження форми, опису знака відповідності технічним регламентам, правил та умов його нанесення» від 30.12.2015 року № 1184//Інформаційно-пошукова система База даних «Законодавство». Версія 2.8.8. («Назва з екрану»).

187. Постанова Кабінету Міністрів України «Про утворення Національної ради 3 географічних назв» від 23.09.1993 року № 783//ннформаційно-пошукова система База даних «Законодавство». Версія 2.8.8. («Назва з екрану»).

188. Постанова Кабінету Міністрів України «Про затвердження Правил розроблення проектів технічних регламентів, що затверджуються Кабінетом Міністрів України, на основі актів законодавства Європейського Союзу» від 18 червня 2012 року № 708//Інформаційно-пошукова система База даних «Законодавство». Версія 2.8.8. («Назва з екрану»).

189. Постанова Кабінету Міністрів України «Про затвердження технічних регламентів щодо енергетичного маркування» від 7 серпня 2013 року № 702//Інформаційно-пошукова система База даних «Законодавство». Версія 2.8.8. («Назва з екрану»).

190. Постанова Кабінету Міністрів України «Про затвердження Технічного регламенту засобів вимірювальної техніки» від 24.02.2016 року № 
163//Інформаційно-пошукова система База даних «Законодавство». Версія 2.8.8. («Назва з екрану»).

191. Постанова Кабінету Міністрів України «Про затвердження Положення про базову організацію з науково-технічної діяльності у будівництві» від 14.07.2010 року № 589//Інформаційно-пошукова система База даних «Законодавство». Версія 2.8.8. («Назва з екрану»).

192. Постыка В. М. Некоторые актуальные проблемы совершенствования методологии стандартизации и пути их решения (в порядке обсуждения)//Стандарты и качество. 1983. № 5. С. 13-17.

193. Потемкин Г. А. Наука, стандартизация, качество//Стандарты и качество. 1967. № 6. С. 43.

194. Починок К. Б. Стандартизація та сертифікація в контексті адміністративної реформи України//Держава і право. К., 2011. Вип. 53. С. 265-271.

195. Предприятие и материальная ответственность/В. К. Мамутов, В. В. Овсиенко, В.Я. Юдин. К., 1971. 190 с.

196. Правовые вопросы научно-технического прогресса в $\mathrm{CCCP} / \mathrm{M} . \mathrm{M}$. Богуславский, В. А. Дозорцев, О. М. Карпенко и др./под общ. ред. докт. юрид. наук М. М. Богуславского. М., 1967. 511 с.

197. Призначені органи 3 сертифікації в державній системі сертифікації [Електронний ресурc]. URL: http://www.me.gov.ua/Documents/Download?id=9b94 646e-da95-4ad7-81bd-6f12fcbe8f92 (дата звернення 24.12.2016).

198. Призначені органи з сертифікації систем управління в державній системі сертифікації [Електронний ресурс]. URL: http://www.me.gov.ua/Documents/ Download?id=11ae6208-3a91-4065-859f-dd4cf8aea311 (дата звернення 24.12.2016). 199. Призначені органи з оцінки відповідності вимогам технічних регламентів [Електронний pecypc]. URL: http://www.me.gov.ua/Documents/Download?id =528e6092-3850-43f9-83aа-48ef1984722f (дата звернення 24.12.2016).

200. Примак В. Д. Правове значення статусу сторін у відносинах з відшкодування моральної шкоди//Юридична Україна. 2010. № 11. С. 90-97. 
201. Проблеми визначення методів і форм державного регулювання господарських відносин/ О. Подцерковний, О. Ломакіна// Підприємництво, господарство і право. 2002. № 8. С. 3-6.

202. Проект Закону «Про оцінку впливу на довкілля» (реєстраційний № 2009а-д від 22.02.2016 року) [Електронний ресурc]. URL: http://w1.c1.rada.gov.ua /pls/zweb2/webproc4_1?pf3511=58257 (дата звернення 21.12.2016).

203. Проект Закону «Про стратегічну екологічну оцінку» (реєстраційний № 3259д від 08.10.2015 року) [Електронний ресурс]. URL: http://w1.c1.rada.gov.ua/pls/ zweb2/webproc4_1?pf3511=56730 (дата звернення 24.12.2016).

204. Пронская Г. В. О юридическом значении и правовых формах экономической ответственности//Хозяйственное право и эффективность производства. М., 1981. C. 63-67.

205. Пронская Г. В. Правовая организация отраслевых хозяйственных систем (на примере Украинской ССР). К., 1985. 124 с.

206. Пути совершенствования организационных и методических основ стандартизации/Б. Н. Волков, Б. В. Крутов, И. И. Афанасьев//Стандарты и качество. 1983. № 3. С. 14-16.

207. Рабінович П. М. Основи загальної теорії права та держави: навч. посібник.

Вид. 6-е.Х., 2002.160 с.

208. Раска Э. Э., Ребане И. А. Методологические аспекты правового воспитания населения//Советское государство и право. 1977. № 4. С. 109-114.

209. Ратнер М. Л. Основы системы стандартизации (в порядке обсуждения)//Стандарты и качество. 1966. № 4. С. 91-92;

210. Раудсалу В. Ю. Общественное производство и охрана окружающей среды/XXVI съезд КПСС и правовые вопросы совершенствования хозяйственного механизма/отв. ред. В. В. Лаптев. М., 1982. С. 234-240.

211. Реформа державної служби у питаннях та відповідях: практичний посібник для керівників служб управління персоналом/М. Канавець та інші. К., 2016. 176 с. 
[Електронний pecypc]. URL: nads.gov.ua/sites/default/files/imce/2016-0702_posibnuk_security_2.compressed.pdf (дата звернення 18.09.2016).

212. Рішення від 16.09 .2010 у справі № $3 / 33$ [Електронний ресурс]. http://www.reyestr.court.gov.ua/Review/11340785 (дата звернення 06.09.2016).

213. Рішення від 12.05.2015 у справі № 927/372/15 [Електронний ресурс]. http://www.reyestr.court.gov.ua/Review/44213097 (дата звернення 06.09.2016).

214. Рішення від 12.07.2016 у справі № 922/1549/16 [Електронний ресурс]. http://www.reyestr.court.gov.ua/Review/58985129 (дата звернення 06.09.2016).

215. Ринг М. П. Правовое регулирование научно-технического прогресса //Советское государство и право.1972.№ 2. С. 111-121.

216. Ринг М. П. Хозяйственное право и научно-технический прогресс //Хозяйственное право и эффективность производства. М., 1981. С. 68-76.

217. Ровинский М. М. Регулирование качества продукции в новых условиях хозяйственного управления//Советское государство и право. 1967. № 4. С. 66-72. 218. Роїна О. М. Договори у господарській діяльності: практ. посібник. 3-те вид., доп. К., 2009. 800 с. С. 22.

219. Ромашкин П. С. Технический прогресс и советское право//Советское государство и право. 1960. № 1. С. 14-24.

220. Руденко Л.Д. Оскарження учасниками та засновниками договорів, укладених господарським товариством / Л.Д. Руденко // Правовий вісник Української академії банківської справи. - 2015. - № 2(11). - С. 55-59

221. Рудняева Г. А., Москвичева В. П. После санкций//Стандарты и качество. 1977. № 8. C. 85.

222. Сайт Міжнародного союзу електрозв'язку [Електронний ресурс]. URL: http://www.itu.int/ (дата звернення 23.09.2017).

223. Сайт Міжнародної електротехнічної комісії [Електронний ресурс]. URL: http://www.iec.ch/ (дата звернення 23.09.2017).

224. Сакоян Д. I. Застосування адміністративно-господарських санкцій за порушення стандартів до промислових підприємств//Відповідальність у сфері 
господарювання: Сучасний стан і перспективи розвитку: зб. наук. праць/наук. ред. В. К. Мамутов. Донецьк, 2009. С. 120-128.

225. Сакоян Д. І. Правове регулювання стандартизації в промисловості: дис. ... канд. юрид. наук: 12.00.04. Донецьк, 2011. 230 с.

226. Салухіна Н. Г., Язвінська О. М. Стандартизація та сертифікація товарів і послуг: підручник. К., 2010. 336 с.

227. Самощенко И. С. Свобода воли и ее значение для регулирования общественных отношений//Советское государство и право. 1963. № 12. С. 35-44.

228. Саніахметова Н.О.Регулювання підприємницької діяльності в Україні (організаційно-правові аспекти): автореф. дис. ... д-ра юрид. наук: 12.00.07.Одеса, 1998. $32 \mathrm{c}$.

229. Сашников В. И., Кузнецов В. С. О санкциях за нарушение стандартов и технических условий при производстве промышленной продукции//Стандарты и качество. 1984. № 8. С. 55-56.

230. Семитко А. П. Правовая культура//Теория государства и права/под ред. В. М. Корельского и В. Д. Перевалова. М., 1997. С. 330-331.

231. Скакун О. Ф. Теория государства и права: Учебник. Х., 2000.704 с.

232. Скакун О.Ф. Теорія держави і права: підручник/Пер. з рос. Харків, 2001. 656 с.

233. Скакун О. Ф. Теорія права і держави: підручник. 2-ге видання. К., 2011.520 с.

234. Словник української мови: в 11 томах. Т. 10. 1979. 658 с.

235. Смоленг I. Держспоживзахист на Волині роздав штрафів на 62,6 млн грн.//Західна інформаційна корпорація (ZIK) [Електронний ресурс]. URL: http://zik.ua/news/2014/01/09/derzhspozhyvzahyst_na_volyni_rozdav_shtrafiv_na_626 _mln_grn_451693 (дата звернення 12.12.2016).

236. Смолин Г. В.Державне регулювання господарської діяльності: курс лекцій. Львів, 2012. 528 с.

237. Собчак А. А. Правовое регулирование хозяйственной деятельности: учеб. пособие. Л., 1981. 167 с. 
238. Советское законодательство и хозяйственный механизм/под ред. М. Г. Масевич. М., 1984.272 с.

239. Советское хозяйственное право: учебник/Л. К. Воронова, Г. В. Дручок, Г. Л. Знаменский/под общ. ред. И. Г. Побирченко. К., 1985. 335 с.

240. Соловьев А. Н. Требования к нормативно-технической документации, представляемой на государственную регистрацию (обзор действующих постановлений и положений)//Стандарты и качество. 1984. № 2. С. 52-54.

241. Солоха Д. В., Бєлякова О. В. Законодавча складова управління розвитком ринку екологічно чистих товарів промислово розвиненого регіону//Напрями удосконалення протидії правопорушенням у сфері господарської діяльності: зб. наук. праць. К., 2010. С. 398-402.

242. Стешов В. А. Хотя по стандарту, но не качественно//Стандарты и качество. 1966. № 4. С. 93.

243. Стравинский Л. А. О задачах унификации и стандартизации в промышленности//Стандарты и качество. 1967. № 7. С. 12-14.

244. Основи стандартизації та сертифікації товарів та послуг/I. П. Студеняк, Ю. М. Ажнюк, І. М. Чучка. К.,2007. 152 с.

245. Сукач М. К. Основи стандартизації: навч. посібник. 2-ге видання, перероб. і доп. К., 2016. 324 с.

246. Суханов Е. А. Гражданское и хозяйственное права европейских социалистических стран-членов СЭВ. М., 1984. 184 с.

247. Теоретические проблемы хозяйственного права/под ред. В.В. Лаптева. М., $1975.413 \mathrm{c}$.

248. Теньков С. О. Науково-практичний коментар до Господарського кодексу України від 16.01.2003 р. К., 2004. 720 с.

249. Типовая форма договора на поставку товаров и услуг [Електронний ресурс]. URL: https://tender.zorya.com.ua/GetFile.ashx?type=2\&dor=4 (дата звернення 25.06.2016). 
250. Тихомиров Ю. А. Административное право и процесс: полный курс. М., $2001.652 \mathrm{c}$.

251. Толстой Ю. К. К теории правоотношений. Ленинград, 1959. 88 с.

252. Трофанчук Г. І. Історія держави і права зарубіжних країн: навч. посібник. К., 2006. $400 \mathrm{c}$.

253. Трошин А. Ф. Роль технико-юридических норм в развитии способностей работников//Советское государство и право. 1980. № 8. С. 66-80.

254. Тягай Д. Е. Система законодательства о стандартизации и формы ее совершенствования при подготовке Свода законов СССР//Стандарты и качество. 1983. № 1. C. 28-30.

255. Угода про технічні бар'єри у торгівлі від 15.04.1994 року//Інформаційнопошукова система База даних «Законодавство». Версія 2.8.8. («Назва з екрану»). 256. Українське агентство зі стандартизації [Електронний ресурс]. URL: http://uas.org.ua/ (дата звернення: 25.06.2016).

257. Фритцше Ф. Стандартизация и качество//Стандарты и качество. 1967. № 10. C. 13-14.

258. Халфина Р. О. Право как средство социального управления. М., 1988. 254 с. 259. Хозяйственное право: учебник/В. К. Мамутов, Г. Л. Знаменский, В. В. Хахулин и др./под ред. В. К. Мамутова. К., 2002.910 с.

260. Хрестоматія 3 історії держави і права України/упоряд. А. С. Чайковський (кер.), О. Л. Копиленко, В. В. Свистунов, Г. І. Трофанчук. К., 2003. 656 с.

261. Цимерман Ю. С. Производственная единица - правовое положение и хозяйственные связи/отв. ред. Н. С. Малеин. М., 1983. 112 с.

262. Цициліано О. Д., Зіміна Г. К. Креативність та стандартизація як основа конкурентоспроможності організації//Стандартизація. Сертифікація. Якість. 2007. № 1 (44). С. 66-71.

263. Шебанов А. Ф. Форма советского права. М., 1968. 213 с.

264. Шевердіна О.В.Правові аспекти державного регулювання господарської діяльності//Хозяйственное законодательство Украины: практика применения и 
перспективы развития в контексте европейского выбора: сб. науч. тр./редкол. Мамутов В. К. (отв. ред.) и др. Донецк, 2005. С. 177-180.

265. Шене Г. Стандартизация - один из основных видов комплексной социалистической рационализации//Стандарты и качество. 1967. № 10. С. 10-12. 266. Шоилицэ Л. Л. Повышать ответственность за соблюдение стандартов//Стандарты и качество. 1984. № 1. С. 40.

267. Шостьин Н. А. Очерки истории русской метрологии. XI - начало XX века. M., $1975.272 \mathrm{c}$.

268. Шохин А. А. Эффективность правового регулирования хозяйственного механизма в промышленности//Хозяйственное право и эффективность производства. М., 1981. С. 118-123.

269. Щербина В. Господарсько-правова відповідальність: галузевий підхід, особливості застосування та напрямки подальших наукових досліджень//Вісник Київського національного університету імені Тараса Шевченка. Юридичні науки. 2013. Вип. 3. С. 10-16 [Електронний ресурс]. URL:http://nbuv.gov.ua/UJRN/VKNU _Yur_2013_3_3 (дата звернення 12.12.2016).

270. Щербина В. С. Господарське право України: навч. посібник. 2-ге вид., перероб. і доп. К., 2001. 592 с.

271. Щербина $\quad$ В. С., Ющик O. I. Хотіли як краще...а вийшло як завжди//Юридичний вісник України. 2005. № 45 [Електронний ресурс]. Режим доступу до журналу: http://yurincom.com/ua/legal_bulletin_of_Ukraine/archive/ ?aid=1059\&jid=139 (дата звернення 12.12.2016)

272. Щербина В. Поняття та види засобів державного регулювання господарської діяльності//Вісник КНУ імені Тараса Шевченка. Юридичні науки. 2012. № 94. С. 10-15. 273. Щербина В. С. Господарське право. К., 2003. С. 6-7.

274. Щербина В. С. Господарське право: підручник.2-е вид., перероб. і доп. К., 2005. 592 c.

275. Щербина В. С. Господарське право: підручник. 4-те вид., перероб. і допов. К., 2009. 640 c. 
276. Щокін Р. Г. Некомерційна господарська діяльність в Україні: сутність, нормативно-правова основа та проблемні аспекти//Наше право. № 1. 2015. С.115120.

277. Юлдашев О. Х. Регуляторна реформа в Україні//Проблеми господарського права і методика його викладання: зб. наук. праць/редкол. Мамутов В. К. (відп. ред.) та ін. Донецьк., 2006. С. 51-62.

278. Юлдашев O. Х. Проблеми вдосконалення правового регулювання господарської діяльності//Хозяйственное законодательство Украины: практика применения и перспективы развития в контексте европейского выбора: сб. науч. тр./редкол. Мамутов В. К. (отв. ред.) и др. Донецк, 2005. С. 50-53.

279. Юринець В. Є. Методологія наукових досліджень: навч. посібник. Львів, 2011. $178 \mathrm{c}$.

280. Ямкова I. М. До питання про засоби державного регулювання господарської діяльності громадян в Україні//Форум права. 2011. № 2. С. 1068-1073.

281. Ямова 3. Д. Стандартизация в период Великой отечественной войны и в послевоенные годы/Стандартизация. 1965. № 9. С. 6-8.

282. Ямова 3. Д. Основные этапы развития стандартизации в СССР//Стандартизация. 1965. № 8. С. 14-19.

283. Ярмоленко О. С. Поняття та зміст адміністративної відповідальності в сучасних умовах//Напрями удосконалення протидії правопорушенням у сфері господарської діяльності: зб. наук. праць. К., 2010. С. 449-453.

284. Яцавиченсе Б. Ю. Рекомендательные нормы в законодательстве о сельском хозяйстве (по материалам Литовской СCP)// XXVI съезд КПСС и правовые вопросы совершенствования хозяйственного механизма/отв. ред. В. В. Лаптев. М., 1982. C. 203-209.

285. Agreement on technical co-operation between ISO and CEN (Vienna Agreement) [Електронний ресурc]. URL:http://isotc.iso.org/livelink/livelink/fetch/2000/2122/ 4230450/4230458/Agreement_on_Technical_Cooperation_between_ISO_and_CEN_(V ienna_Agreement).pdf (дата звернення 23.09.2017). 
286. Annual Report 2014-15, the Mental Health Commission of Canada (MHCC) [Електронний ресурc]. URL: https://www.mentalhealthcommission.ca/English/annualreport-2014-2015 (дата звернення 23.09.2017).

287. Consumer standards overview [Електронний pecypc]. URL: http:// isotc.iso.org/livelink/livelink/fetch/-

8925727/8925750/16474221/List_of_consumer\%2Dfacing_standards_originating_with _or_contributed_to_heavily_by_COPOLCO.pdf?nodeid=19072470\&vernum=-2 (дата звернення 23.09.2017).

288. ISO/IEC GUIDE 2:2004(E/F/R) Standardization and related activities - General vocabulary [Електронний pecypc]. URL: https://www.iso.org/files/live/sites/ isoorg/files/archive/pdf/en/iso_iec_guide_2_2004.pdf (дата звернення 23.11.2017).

289. La normazione? Aiuta a incrementare il PIL. Venerdì, 10 Ottobre 2014 [Електронний pecypc]. URL: http://www.uni.com/index.php?option=com_content $\&$ view=article $\&$ id=3132:la-normazione-aiuta-a-incrementare-il-pil\&catid=171:istituzi onale\&Itemid=2612 (дата звернення 12.11.2014).

290. OHSAS 18001:2007 «Occupational health and safety management systems Requirements» [Електронний ресурc]. URL: https://www.ohsas-18001-occupationalhealth-and-safety.com/ (дата звернення 22.09.2016).

291. Popovych T. G. International vision of standardization as a means of regulating economic entities of terms of instability and globalization // Приватне право i підприємництво. 2018. Вип. 18. С. 185-190.

292. Popovich T. G. Standardization in the mechanism of legal regulation of business activity // Сборник научных трудов SWORLD. Vol. 46. № 4. P. 58-61. ISSN: 22240187. ID=21110426.

293. Regulation (EU) No 1025/2012 of the European Parliament and of the Council of 25 October 2012 on European standardization [Електронний ресурc]. URL:http://eurlex.europa.eu/LexUriServ/LexUriServ.do?uri=OJ:L:2012:316:0012:0033:EN:PDF (дата звернення 23.09.2017). 
294. Staes P. Quality Management on the European Agenda/P. Staes, N. Thijs// EIPAScope. 2005. № 1.

295. Staes P. Report on the State of Affairs of the Common Assessment Framework (CAF) after Five Years/P. Staes, N. Thijs//EIPAScope. 2005. № 3.5.

296. Stupnytskyy V. Use of the CAF-system (Computer Aided Forming) in Integer Computer Aided Manufacturing// Papers of the XX Ukrainian-Polish Conference on CAD in Machinery Design. Implementation and Educational Issues - CADMD 2012. Lviv. P. 45-48.

297. The economic benefits of standardization are estimated to account for around $1 \%$ of gross domestic product (GDP) [Електронний pecypc]. URL: https://www.snv.ch/ en/normung/normungsprozess/volkswirtschaflticher-nutzen/ (дата звернення 23.09.2017).

298. The Use of CAF in Europe. European Institute of Public Administration [Електронний pecypc]. URL: http://www.eipa.eu/en/pages/show/\&tid=71 (дата звернення 23.09.2017). 


\section{ДОДАТКИ}

Додаток $A$

\section{Список публікацій здобувача:}

Статті у вітчизняних наукових фахових виданнях:

1. Попович Т. Г. Зміна правових засад у сфері технічного регулювання в Україні відповідно до вимог СС // Приватне право і підприємництво. Вип. 16. 2016. С. $141-144$.

2. Попович Т. Г. Господарська діяльність в умовах дії Угоди про асоціацію України з СС // Приватне право і підприємництво. 2017. Вип. 17. С. 152-156.

3. Popovych T. G. International vision of standardization as a means of regulating economic entities of terms of instability and globalization // Приватне право i підприємництво. 2018. Вип. 18. С. 185-190.

4. Попович Т. Г. Стандартизація чи технічне регулювання: вдосконалення понятійного апарату господарського права на основі міжнародного досвіду // Юридична Україна. 2018. № 1-2. С. 59-65.

Статті у наукових періодичних виданнях інших держав та виданнях, які включено до міжнародних наукометричних баз:

5. Popovich T. G. Standardization in the mechanism of legal regulation of business activity // Сборник научных трудов SWORLD. 2013. Vol. 46. № 4. P. 58-61. ISSN: 2224-0187. ID=21110426.

\section{Опубліковані пращі,} які додатково відображають наукові результати дисертаиії:

6. Попович Т. Г. Екологічний менеджмент акціонерних товариств: економікоправовий аспект // Корпоративне право в Україні: становлення та розвиток. Збірник наукових праць. К., 2004. С.228-233.

7. Попович Т. Г. Свропейський Союз: перспективи для українських підприємств// Нормативно-правове забезпечення євроатлантичної інтеграції України. Вип. 1. K., 2004. C. 159-161. 
8. Попович Т. Г. Визначення критеріїв ефективності стандартів у сфері охорони довкілля // Приватне право і підприємництво. Вип. 4. 2005. С. 183-188.

9. Попович Т. Г. Екологічно безпечне житло: реалії та правове регулювання. К., 2006. $32 \mathrm{c}$.

10. Попович Т. Г. Додаткові елементи механізму правового регулювання стандартизації в господарському праві // Актуальні проблеми реформування земельних, аграрних та господарських відносин: збірник тез Міжнародної науково-практичної конференції (м. Хмельницький , 17-18 травня 2013 року). Хмельницький, 2013. С. 424-427

11. Попович Т. Г. Впровадження стандартизації в господарській діяльності як прояв захисту суб'єктивних цивільних прав // Проблеми здійснення та захисту суб’єктивних цивільних прав: Збірник наукових праць. К., 2012. С. 148-150.

12. Попович Т. Г. Регулювання господарської діяльності 3 допомогою стандартизації на основі принципу добровільності // Діалектика публічних і приватних інтересів у державному регулюванні економіки: Зб. матеріалів «Круглого столу». К., 2013. С. 176-181.

13. Попович Т. Г. Особливості застосування стандартизації в умовах набуття чинності Угодою про асоціацію між Україною та СС // Проблеми модернізації приватного права в умовах євроінтеграції: збірник наукових праць. Хмельницький, 2015. С. 188-194.

14. Попович Т. Г. Міжнародно-правові основи стандартизації як засобу регулювання господарської діяльності // Міжгалузеві зв'язки цивільного, господарського та трудового права: матеріали Веукраїнської науковопрактичної конференції (в авторській редакції), (м. Кривий Ріг, 28 вересня 2017 року): [у 2-х част.]. Ч. 1. Кривий Ріг, 2017. С. 183-187.

15. Попович Т. Г. Правові аспекти приведення у відповідність до вимог ЄС системи технічного регулювання у сфері господарської діяльності в Україні // Забезпечення міжнародної приватноправової інтеграційної стратегії. К., 2017. C. $156-172$. 
16. Попович Т. Г. Співвідношення стандартизації та технічного регулювання у господарському праві // Збірник праць XII аспірантських та магістерських читань «Актуальні проблеми розвитку України у контексті сучасних світових тенденцій» (23 листопада 2017 року, м. Київ). К., 2018. С. 122-128.

17. Попович Т. Г. Стандартизація як засіб регулювання господарської діяльності: монографія. К., 2018. 224 с.

\section{ВІДОМОСТІ ПРО АПРОБАЦІЮ РЕЗУЛЬТАТІВ ДИСЕРТАЦЇ̈:}

Підсумки розроблення проблеми в цілому, окремих іï аспектів, одержані узагальнення і висновки було оприлюднено на: засіданнях вченої ради Науководослідного інституту приватного права i підприємництва імені академіка Ф. Г. Бурчака НАПрН України, науково-практичних конференціях «Становлення та розвиток корпоративного права» (м. Івано-Франківськ, 26-27.09.2003, особиста участь), «Нормативно-правове забезпечення процесів євроатлантичної інтеграції України» (м. Київ, 24.09.2004, особиста участь), «Актуальні проблеми реформування земельних, аграрних та господарських відносин» (м. Хмельницький, 17-18.05.2013, особиста участь), «Проблеми модернізації приватного права в умовах євроінтеграції» (м. Хмельницький, 2-3.10.2015, особиста участь), «Міжгалузеві зв’язки цивільного, господарського та трудового права» (м. Кривий Ріг, 28.09.2017, заочна участь), наукових круглих столах «Проблеми здійснення та захисту суб'єктивних цивільних прав» (м. Київ, 56.10.2012, особиста участь), «Діалектика приватних і публічних інтересів в державному регулюванні господарської діяльності» (м. Київ, 08.11.2013, особиста участь), аспірантських та магістерських читаннях «Актуальні проблеми розвитку України у контексті сучасних світових тенденцій» (м. Київ, 23.11.2017, особиста участь). 
Додаток Б

\section{Акти впровадження результатів дисертації}

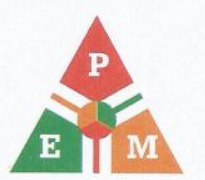

ТОВ “Науково Виробниче Підприємство" РЕМ-ЕЛЕКТРО-МОНТАЖ”

p/p 26008014033835 в Філія АТ “Укрексімбанк” м. Києва МФО 380333 ЄДРПО 34289059 ІІН 342890526502 свід. ПДВ № 37122339

Є платником податку на прибуток на загальних підставах

\section{Акт впровадження}

Комісія у складі директора Ремеза В. І., технічного директора Ремеза В. В., головного інженера Менчинського В. С. склала цей акт про те, що ТОВ «НВП «РЕМЕЛЕКТРО-МОНТАЖ» у 2017-2018 роках впроваджувала у своїй діяльності результати дисертаційного дослідження Попович Тетяни Григорівни «Стандартизація як засіб регулювання господарської діяльності», поданого на здобуття наукового ступеня кандидата юридичних наук за спеціальністю 12.00.04- господарське право; господарсько-процесуальне право.

Комісія вважає, що зазначені у дисертаційному дослідженні висновки та пропозиції щодо раціонального співвідношення застосування обов'язкових та добровільних вимог у різних сферах та галузях народного господарства $є$ обгрунтованими та дозволять вдосконалити сучасну національну систему стандартизації, а включення таких вимог як обов'язкових у договори полегшує співпрацю між сторонами. Так, при здійснениі підрлдних робіт в умови договору нами додатково включалися специфікації та особливості робіт відповідно до існуючих вимог ДБН, ДСТУ та інших документів, що дозволило нам та нашим замовникам взаємно виконувати зобов'язання за спрощеними алгоритмами. Така наша позиція, надання доступу до спеціалізованих знань та відкритість дозволяє покращити іміджеві показники нашого підпрйемства.

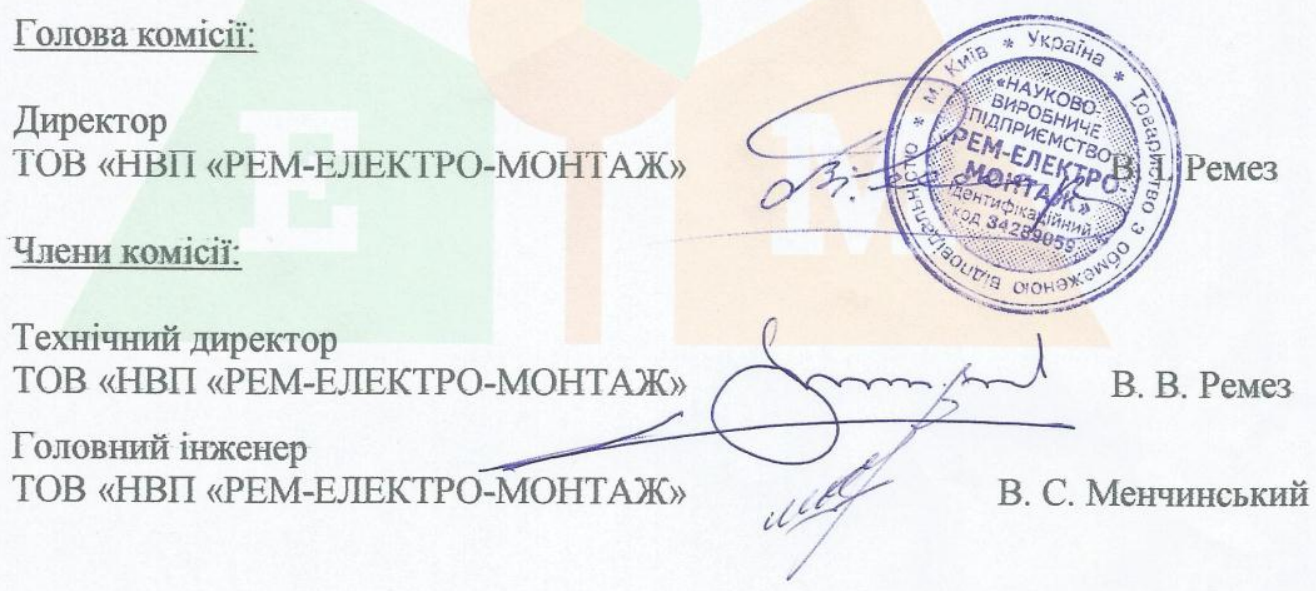




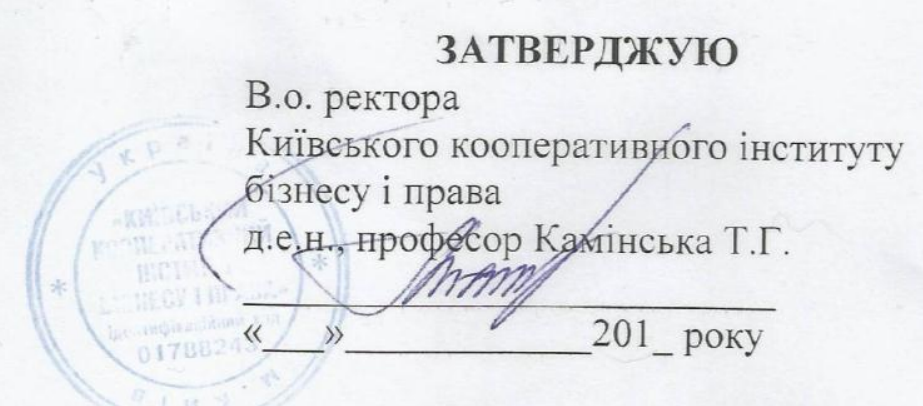

Акт

про впровадження результатів дисертаційного дослідження Попович Тетяни Григорівни на тему: «Стандартизація як засіб регулювання господарської діяльності»

Комісія у складі: завідувач кафедри права, доктор юридичних наук, професор В.А. Омельчук, члени комісії: к.ю.н, доцент кафедри права О.Ф. Калініченко, старший викладач кафедри права О.С. Зіньова склала цей акт про те, що результати дисертаційного дослідження Попович Тетяни Григорівни «Стандартизація як засіб регулювання господарської діяльності», поданого на здобуття наукового ступеня кандидата юридичних наук за спеціальністю 12.00 .04 - господарське право; господарсько-процесуальне право, були впроваджені у навчальному процесі Київського кооперативного інституту бізнесу і права.

Запропоновані автором теоретичні та методологічні підходи до оволодіння знаннями у сфері господарського права, зокрема щодо стандартизації як засобу регулювання господарської діяльності, забезпечують досконаліше розуміння та поглиблене вивчення студентами цієї галузі знань.

Результати теоретичного дослідження Попович Тетяни Григорівни мають наукове та практичне значення. Вони використані у матеріалах лекцій та методичних рекомендацій з дисциплін: «Господарське право».

Голова комісіі:

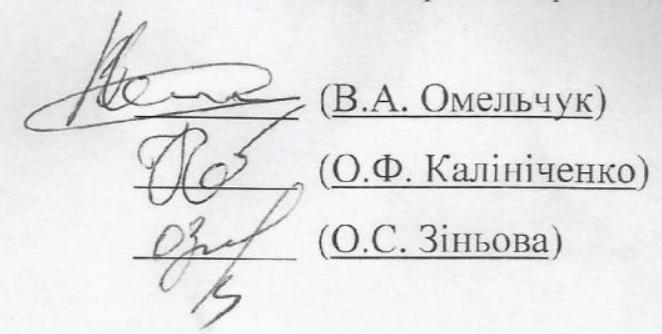

Члени комісії: 


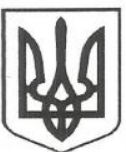

Національна академія правових наук України

\section{НАУКОВО-ДОСЛІДНИЙ ІНСТИТУТ \\ ПРИВАТНОГО ПРАВА І ПІДПРИСМНИЦТВА \\ ІМЕНІ АКАДЕМІКА Ф.Г.БУРЧАКА}

Україна, 01042, Київ, вул. М. Раєвського, 23а, а/с - 136 код 19485263 тел. (044) 286-70-98 факс 284-87-35 E-Mail: ndippp a adamant.net

\section{ДОВІДКА ІІРО ВІІРОВАДЖЕННЯ}

Комісія у складі директора Інституту, доктора юридичних наук, професора, академіка НАПрН України Крупчана О. Д., завідувача відділу міжнародного приватного права та порівняльного правознавства Інституту, доктора юридичних наук Короля В. I., вченого секретаря Інституту, кандидата юридичних наук Рєзнік Г. О. склала цей акт про те, що положення та рекомендації кандидатської дисертації Попович Т. Г. на тему «Стандартизація як засіб регулювання господарської діяльності» (спеціальність 12.00.04 - господарське право; господарсько-процесуальне право) були враховані при розробці проекту Закону України «Про внесення змін до деяких законодавчих актів України щодо усунення технічних бар'єрів у торгівлі і забезпечення прав та інтересів осіб у сфері стандартизації,, який розроблявся у межах науково-дослідної теми «Інституційноправове забезпечення майнових інтересів держави та суб'єктів приватного права в умовах регіональної нестабільності» (номер державної реєстрації 0117U002141) та подавався до Комітету Верховної Ради України 3 питань промислової політики та підприємництва (отримано лист-відповідь № 04-30/14-107/48089 від 01.03.2017 за підписом Голови Комітету В. В. Галасюка).

Результати дослідження Попович Т. Г. використовувалися також у процесі виконання досліджень за фундаментальними темами, над якими працював Науководослідний інститут приватного права і підприємництва імені академіка Ф. Г. Бурчака НАПрН України, а саме: «Правове забезпечення регіональних інтеграційних стратегій України в контексті модернізаційної політики держави» (№ державної реєстрації 0113U001118), «Інституційно-правове забезпечення майнових інтересів держави та суб'єктів приватного права в умовах регіональної нестабільності» (№ державної реєстрації 0117U002141), «Приватноправові проблеми реалізації євроінтеграційної стратегії України» (№ державної реєстрації 0117U002140).

Комісія вважає, що зазначені у дисертаційному дослідженні висновки та пропозиції щодо внесення змін до деяких законодавчих актів України щодо усунення технічних бар'єрів у торгівлі та забезпечення прав заінтересованих осіб у сфері стандартизації $є$ обгрунтованими та дозволять вдосконалити сучасну національну систему стандартизації, що включає в себе технічне регулювання, а також сприятимуть розвитку економіки, усуненню технічних бар'єрів у торгівлі та забезпеченню прав заінтересованих осіб у сфері стандартизації.

Голова комісії

Члени комісії

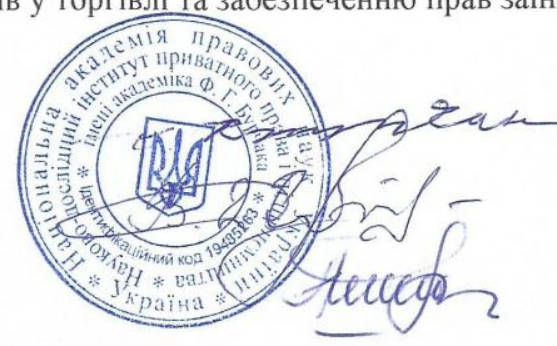

О. Д. Крупчан

В. І. Король

Г. О. Рєзнік 
Додаток B

Проект

\author{
ЗАКОН УКРАЇНИ \\ Про внесення змін та доповнень \\ до Закону України «Про стандартизацію»
}

Пропонуємо такі зміни та доповнення до Закону України «Про стандартизацію» (у редакції від 10.02.2016 року):

1. Статтю 1 доповнити новим поняттям «нормативно-технічний документ документ, прийнятий уповноваженим на це суб'єктом нормотворення у визначеній законом формі та порядку, який встановлює правила, загальні принципи, технічні характеристики та/чи інші вимоги до різних видів діяльності або її результатів (у тому числі товарів та послуг) та розрахований на неодноразове застосування. До нормативно-технічних документів належать національні стандарти, технічні та інші регламенти, кодекси усталеної практики (настанови, правила, зведення правил), технічні умови, державні класифікатори, стандарти підприємств та інші документи, що містять вимоги до різних видів діяльності або ії результатів (у тому числі товарів та послуг)».

2. У Статті 1 визначення поняття «стандартизація» викласти у такій редакції: «стандартизація - діяльність, що полягає в установленні та застосуванні положень для загального та неодноразового використання щодо наявних чи потенційних завдань і спрямована на досягнення оптимального ступеня впорядкованості в певній сфері суспільного життя для забезпечення мети стандартизації. Стандартизація включає в себе технічне регулювання та оцінку відповідності».

3. Частину 2 статті 16 доповнити новим реченням «Щодо цих нормативнотехнічних документів діє презумпція відповідності результатів господарської діяльності вимогам стандартизації, що застосовуються в добровільному порядку, у разі заявлення (декларування) їх у маркуванні товарів (послуг) чи іншим способом».

Науковий співробітник Науково-дослідного інституту приватного права та підприємництва імені академіка Ф. Г. Бурчака Національної академії правових наук України

Т. Г. Попович 
Порівняльна таблиця

до Проекту Закону України Про внесення змін та доповнень до Закону України «Про стандартизацію»

\begin{tabular}{|c|c|}
\hline Чинна редакція & Нова редакція \\
\hline $\begin{array}{l}\text { Стаття } 1 \text { Визначення термінів } \\
\text { 1. У цьому Законі терміни } \\
\text { вживаються в такому значенні: } \\
\ldots \\
\text { немає }\end{array}$ & $\begin{array}{l}\text { Стаття } 1 \text { Визначення термінів } \\
\text { 1. У цьому Законі терміни } \\
\text { вживаються в такому значенні: } \\
\text {.. } \\
\text { нормативно-технічний документ - } \\
\text { документ, прийнятий } \\
\text { уповноваженим на це суб'єктом } \\
\text { нормотворення у визначеній } \\
\text { законом формі та порядку, який } \\
\text { встановлює правила, загальні } \\
\text { принципи, технічні характеристики } \\
\text { та/чи інші вимоги до різних видів } \\
\text { діяльності або їі результатів (у тому } \\
\text { числі товарів та послуг) та } \\
\text { розрахований на неодноразове } \\
\text { застосування. До нормативно- } \\
\text { технічних документів належать } \\
\text { національні стандарти, технічні та } \\
\text { інші регламенти, кодекси усталеної } \\
\text { практики (настанови, правила, } \\
\text { звддення правил), технічні умови, } \\
\text { державні класифікатори, стандарти } \\
\text { підприємств та інші документи, що } \\
\text { містять вимоги до різних видів } \\
\text { діяльності або їі результатів (у тому } \\
\text { числі товарів та послуг) }\end{array}$ \\
\hline $\begin{array}{l}\text { Стаття } 1 \text { Визначення термінів } \\
\text { 1. У цьому Законі терміни } \\
\text { вживаються в такому значенні: } \\
\text { 21) стандартизація - діяльність, що } \\
\text { полягає в установленні положень для } \\
\text { загального та неодноразового } \\
\text { використання щодо наявних чи } \\
\text { потенційних завдань і спрямована на } \\
\text { досягнення оптимального ступеня } \\
\text { впорядкованості в певній сфері; }\end{array}$ & $\begin{array}{l}\text { Стаття 1 Визначення термінів } \\
\text { 1. У цьому Законі терміни } \\
\text { вживаються в такому значенні: } \\
\text { 21) стандартизація - діяльність, що } \\
\text { полягає в установленні та } \\
\text { застосуванні положень для } \\
\text { загального та неодноразового } \\
\text { використання щодо наявних чи } \\
\text { потенційних завдань і спрямована на } \\
\text { досягнення оптимального ступеня } \\
\text { впорядкованості в певній сфері } \\
\text { суспільного життя для забезпечення } \\
\text { мети стандартизації. }\end{array}$ \\
\hline
\end{tabular}




\begin{tabular}{|c|c|}
\hline & $\begin{array}{l}\text { Стандартизація включас в себе } \\
\text { технічне регулювання та оцінку } \\
\text { відповідності }\end{array}$ \\
\hline $\begin{array}{l}\text { Стаття 16. Підприємства, установи та } \\
\text { організації, що здійснюють } \\
\text { стандартизацію } \\
\text {.. } \\
\text { 2. Стандарти, кодекси усталеної } \\
\text { практики та технічні умови, прийняті } \\
\text { підприємствами, установами та } \\
\text { організаціями, застосовуються на } \\
\text { добровільній основі. }\end{array}$ & $\begin{array}{l}\text { Стаття 16. Підприємства, установи та } \\
\text { організації, що здійснюють } \\
\text { стандартизацію } \\
\text {.. } \\
\text { 2. Стандарти, кодекси усталеної } \\
\text { практики та технічні умови, прийняті } \\
\text { підприємствами, установами та } \\
\text { організаціями, застосовуються на } \\
\text { добровільній основі. Щодо цих } \\
\text { нормативно-технічних документів } \\
\text { діс презумпція відповідності } \\
\text { результатів господарської } \\
\text { діяльності вимогам стандартизації, } \\
\text { що застосовуються в добровільному } \\
\text { порядку, у разі заявлення } \\
\text { (декларування) їх у маркуванні } \\
\text { товарів (послуг) чи іншим способом }\end{array}$ \\
\hline
\end{tabular}

Науковий співробітник Науково-дослідного інституту приватного права та підприємництва імені академіка Ф. Г. Бурчака Національної академії правових наук України Т. Г. Попович 


\section{ПОЯСНЮВАЛЬНА ЗАПИСКА \\ до Проекту Закону України Про внесення змін та доповнень до Закону України «Про стандартизацію»}

\section{1. Обгрунтування необхідності прийняття акта}

У Науково-дослідному інституті приватного права і підприємництва імені академіка Ф. Г. Бурчака Національної академії правових наук України здійснюється науково-дослідна робота за темою «Правове забезпечення регіональних інтеграційних стратегій України в контексті модернізаційної політики держави», в межах якої досліджено науково-теоретичні основи стандартизації в Україні в умовах адаптації законодавства України до вимог СС, іiі місця в системі елементів та на стадіях правового регулювання господарської діяльності. У процесі дослідження було виявлено місце стандартизації в механізмі правового регулювання господарської діяльності, де вона виступає як елемент такого регулювання, дозволяє сприяти економічному розвитку суб'єктів господарювання, а також забезпечує стабільність господарського обороту, формує уніфіковані правила економічної конкуренції, захист прав споживачів, охорону довкілля та забезпечення національної безпеки.

Перехід від «радянського» розуміння стандартизації та пов'язаних 3 нею інших видів діяльності до сучасних реалій та потреб суспільства вимагає оновлення понятійного апарату у цій сфері, що мають відповідати вимогам ЄС, СОТ та інших міжнародних організацій (інституцій). Часто стандартизацію розуміють як інструмент продовольчої безпеки, безпеки харчування, якості продукції. Інколи застосовують це поняття лише стосовно встановлення вимог до технічних характеристик товару (послуги) або до процесів його виробництва. Насправді стандартизація проявляється на усіх стадіях правового регулювання господарської діяльності, що дозволяє: а) у процесі нормотворення - забезпечити основу для подальшої ефективної господарської діяльності та усуненню бар'єрів в торгівлі; б) при правозастосуванні - вигідно укласти договори, отримати конкурентну перевагу на ринку, зацікавити споживача; в) у разі покладання юридичної відповідальності можливість довести наявність чи відсутність порушення нормативно-технічних документів суб'єктом господарювання, відшкодувати збитки.

Стандартизація проявляється як у статиці (при встановленні вимог), так і у динаміці (при застосуванні вимог та підтвердженні відповідності товарів (послуг) вимогам, що були застосовані). Саме тому варто говорити про технічне регулювання та оцінку відповідності як складові частини стандартизації.

Ще одним важливим питанням $є$ застосування принципу добровільності в стандартизації. Недостатня розробка добровільності у стандартизації призводить до часткової невідповідності фактичного розуміння цього принципу. Так, Рішення Ради ЄС від 07.05.1985 року про новий підхід до технічної гармонізації та стандартів (85/C 136/01) говорить про добровільність стандартів (необов'язковість вимог), але відзначає, що виробник може обирати стандарти, але потім у нього виникає зобов'язання довести, що його продукція відповідає основним вимогам 
Директиви. Нами пропонується закріпити законодавчо норму, яка презюмує обов'язковість застосування необов'язкових (добровільних) вимог стандартизації у разі їх декларування (у маркуванні продукції, на офіційному сайті, у рекламних матеріалах тощо).

\section{2. Мета і шляхи її досягнення}

Пропозиціями пропонується якісно вдосконалити чинні норми законодавства у сфері стандартизації шляхом наповнення їх визначеннями новим змістом та уточнення принципу добровільності.

Пропонується внести зміни та доповнення до ст. 1 та ч. 2 ст. 16 Закону України «Про стандартизацію» (у редакції від 10.02.2016 року):

1. Статтю 1 доповнити новим поняттям «нормативно-технічний документ документ, прийнятий уповноваженим на це суб'єктом нормотворення у визначеній законом формі та порядку, який встановлює правила, загальні принципи, технічні характеристики та/чи інші вимоги до різних видів діяльності або її результатів (у тому числі товарів та послуг) та розрахований на неодноразове застосування. До нормативно-технічних документів належать національні стандарти, технічні та інші регламенти, кодекси усталеної практики (настанови, правила, зведення правил), технічні умови, державні класифікатори, стандарти підприємств та інші документи, що містять вимоги до різних видів діяльності або ії результатів (у тому числі товарів та послуг)».

2. У Статті 1 визначення поняття «стандартизація» викласти у такій редакції: «стандартизація - діяльність, що полягає в установленні та застосуванні положень для загального та неодноразового використання щодо наявних чи потенційних завдань і спрямована на досягнення оптимального ступеня впорядкованості в певній сфері суспільного життя для забезпечення мети стандартизації. Стандартизація включає в себе технічне регулювання та оцінку відповідності».

3. Частину 2 статті 16 доповнити новим реченням «Щодо цих нормативнотехнічних документів діє презумпція відповідності результатів господарської діяльності вимогам стандартизації, що застосовуються в добровільному порядку, у разі заявлення (декларування) їх у маркуванні товарів (послуг) чи іншим способом».

\section{3. Правові аспекти}

Нормативно-правовими актами у даній сфері правового регулювання $\epsilon$ Конституція України та Закону України «Про стандартизацію» (у редакції від 10.02.2016 року).

Пропозиції про внесення змін та доповнень до Закону України «Про стандартизацію» (у редакції від 10.02.2016 року) належить до пріоритетних сфер адаптації законодавства України до acquis communautaire, визначених Загальнодержавною програмою адаптації законодавства України до законодавства Європейського Союзу, затвердженою Законом України від 18.03.2004 року № 1629-IV. 


\section{4. Фінансово-економічне обгрунтування}

Реалізація пропозицій про внесення змін та доповнень до Закону України «Про стандартизацію» додаткових фінансових витрат 3 Державного бюджету України не потребує.

\section{5. Позиція заінтересованих органів}

Пропозиції про внесення змін та доповнень до Закону України «Про стандартизацію» (у редакції від 10.02.2016 року) вимагають узгодження його змісту із Міністерством юстиції України, Міністерством економічного розвитку і торгівлі України.

\section{6. Регіональний аспект}

Пропозиції про внесення змін та доповнень до Закону України «Про стандартизацію» (у редакції від 10.02.2016 року) не стосуються питання розвитку адміністративно-територіальних одиниць.

\section{6-1. Запобігання дискримінації}

У пропозиціях про внесення змін та доповнень до Закону України «Про стандартизацію» (у редакції від 10.02.2016 року) відсутні положення, які містять ознаки дискримінації.

Пропозиції про внесення змін та доповнень до Закону України «Про стандартизацію» (у редакції від 10.02.2016 року) не потребують проведення громадської антидискримінаційної експертизи.

\section{7. Запобігання корупції}

Пропозиції про внесення змін та доповнень до Закону України «Про стандартизацію» (у редакції від 10.02.2016 року) не включають правила i процедури, які можуть містити ризики вчинення корупційних правопорушень. Пропозиції про внесення змін та доповнень до Закону України «Про стандартизацію» (у редакції від 10.02.2016 року) не потребують проведення громадської антикорупційної експертизи.

\section{8. Громадське обговорення}

Пропозиції про внесення змін та доповнень до Закону України «Про стандартизацію» (у редакції від 10.02.2016 року) потребують проведення консультацій з громадськістю та суб'єктами господарської діяльності.

\section{9. Позиція соціальних партнерів}

Пропозиції про внесення змін та доповнень до Закону України «Про стандартизацію» (у редакції від 10.02.2016 року) не стосуються соціально-трудової сфери. 


\section{0. Оцінка регуляторного впливу}

Пропозиції про внесення змін та доповнень до Закону України «Про стандартизацію» (у редакції від 10.02.2016 року) не є регуляторним актом.

\section{1. Прогноз результатів}

Пропозиції про внесення змін та доповнень до Закону України «Про стандартизацію» (у редакції від 10.02.2016 року) дозволять вдосконалити чинні норми законодавства у сфері стандартизації шляхом наповнення їх визначеннями новим змістом та уточнення принципу добровільності, що забезпечить досягнення мети стандартизації: 1) забезпечення відповідності об'єктів стандартизації своєму призначенню; 2) керування різноманітністю, застосовність, сумісність, взаємозамінність об'єктів стандартизації; 3) забезпечення раціонального виробництва шляхом застосування визнаних правил, настанов і процедур; 4) забезпечення охорони життя та здоров'я; 5) забезпечення прав та інтересів споживачів; 6) забезпечення безпечності праці; 7) збереження навколишнього природного середовища і економія всіх видів ресурсів; 8) усунення технічних бар'єрів у торгівлі та запобігання їх виникненню, підтримка розвитку і міжнародної конкурентоспроможності продукції.

Науковий співробітник Науково-дослідного інституту приватного права та підприємництва імені академіка Ф. Г. Бурчака Національної академії правових наук України Т. Г. Попович 


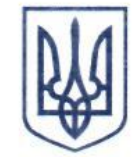

\section{ВЕРХОВНА РАДА УКРАЇНИ}

Комітет 3 питань промислової політики та підприємництва

01008, м. Київ-8, вул. М. Грушевського, 5, тел.: 255-35-95, факс: 255-39-41

№ $04-30 / 14-107 / 48089$

"O1" Sepeftie 2017.

Директору Науково-дослідного інституту приватного права i підприсмництва ім. академіка Ф.Г.Бурчака О.Д.КРУПЧАНУ

вул. Расвського, 23a, а/с 136, м. Київ, 01042

\section{Шановний Олександре Дмитровичу!}

На Ваш лист $з$ пропозиціями стосовно внесення змін та доповнень дс Закону України «Про стандартизацію» повідомляємо, що Комітет щиро вдячний Вам за активну громадську позицію та небайдуже ставлення до розвитку національної економіки в умовах адаптації вітчизняного законодавства у сфері стандартизації до вимог ЄС.

Запропоновані Вами зміни до вищезгаданого Закону дійсно є слушними та актуальними і будуть використані в подальшій законотворчій роботі Комітету.

3 повагою

Голова Комітету

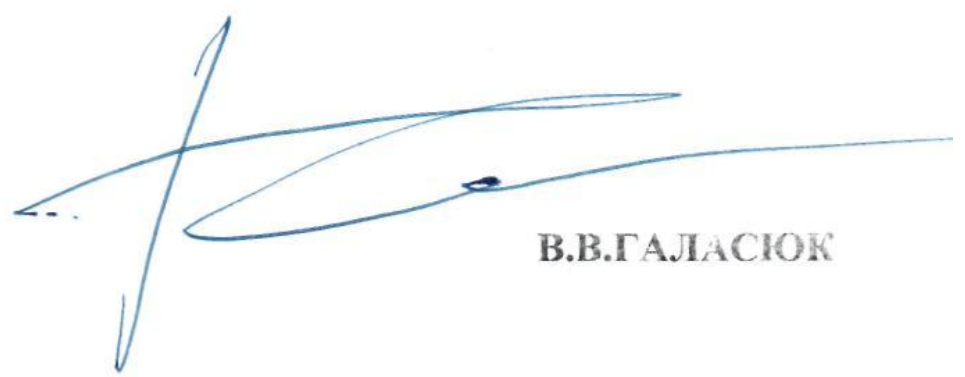

